FERNANDO CÉSAR NIMER MOREIRA DA SILVA

\title{
VENTURE CAPITAL: VALOR DA INFORMAÇÃO, RISCOS E INSTRUMENTOS PARA SUA MITIGAÇÃO
}

\author{
TESE DE DOUTORADO
}

ORIENTADORA: PROFESSORA DOUTORA RACHEL SZTAJN

FACULDADE DE DIREITO DA UNIVERSIDADE DE SÃO PAULO

SÃO PAULO 
Banca Examinadora: 
'What I showed in 'The Problem of Social Cost' was that, in the absence of transaction costs, is does not matter what the law is, since people can always negotiate without cost (...). In such a world the institutions which make up the economic system have neither substance nor purpose. (...) What my argument does suggest is the need to introduce positive transaction costs explicitly into economic analysis so that we can study the world that exists".

(COASE, Ronald H. The firm, the market and the law. In: The firm, the market, and the law. Chicago: University of Chicago Press, 1990, pp. 14-15).

“(.) I think we should try to develop generalizations which would give us guidelines as to how various activities should best be organized and financed. But such generalizations are not likely to be helpful unless they are derived from studies of how such activities are actually carried out within different institutional frameworks. Such studies would enable us to discover which factors are important and which are not in determining the outcome, and they would lead to generalizations which have a solid base. They are also likely to serve another purpose by showing us the richness of the social alternatives among which we can choose”.

(COASE, Ronald H. Lighthouse in economics. In: The firm, the market, and the law. Chicago: University of Chicago Press, 1990, pp. 211-212).

"L'analisi economica del diritto pressupone che il contrato sia la veste giuridica di un'operazione economica, o economicamente valutabile. Da questa medesima premessa discende un'altra conseguenza: per giudicare di una lite su un singolo contratto, 'e necessario cogliere l'operazione economica che questo sottende. Solo rappresentandosi con chiarezza e precisione $i$ termini dell'operazione economica che le parti volevano realizzare (quella che si usa chiamare 'economia del contratto'), possono affrontarsi consapevolmente la gran parte delee questioni rilevanti per decidere - fra $i$ contraenti in lite - chi ha ragione e chi torto".

(ROPPO, Vincenzo. Il contratto. Milano: Ed. Giuffré, 2001, p. 73). 


\section{ÍNDICE}

RESUMO

$\begin{array}{ll}\text { ABSTRACT } & 8\end{array}$

RÉSUMÉ

$\begin{array}{ll}\text { I. INTRODUÇÃO } & 12\end{array}$

I.1. Apresentação e delimitação do te ma $\quad 12$

I.2. Metodologia utilizada 16

$\begin{array}{lr}\text { I.3. Justificativa para a escolha } & 18\end{array}$

$\begin{array}{ll}\text { I.4. Plano da tese } & 19\end{array}$

II. DEFINIÇÕES E CONCEITOS APLICÁVEIS 21

II.1. Negócio de venture capital $\quad 21$

II.1.1. Definição

II.1.2. Elemento diferenciador: incerteza e risco 22

II.2. Características dos contratos 26

II.2.1. Sujeitos e interesses 26

II.2.1.1. Sujeitos 2

$\begin{array}{llr}\text { II.2.1.2. Interesses } & 28\end{array}$

II.2.2. Objeto e finalidade 30

II.2.3. Forma e conteúdo

II.2.4. Natureza 35

II.2.5. Principais problemas $\quad 38$

II.2.5.1. Informação assimétrica 38

II.2.5.2. Conflitos de agente-principal 41

II.2.5.3. Seleção adversa 4

II.2.5.4. Moral hazard 4

II.2.5.5. Ameaças críveis 48

II.2.5.6. Jogo finito

III. TIPOS CONTRATUAIS 55

III.1. Critérios para análise 55

III.2. Evidências empíricas $\quad 5$

III.3. Tipos descartados $\quad 64$

III.3.1. Mútuo $\quad$ G5 
$\begin{array}{llr}\text { III.3.2. Consórcio } & 67\end{array}$

III.3.3. Sociedades e associações $\quad 71$

III.4. Tipos avaliados: sociedade anônima fechada e limitada 80

III.4.1. Principais categorias de riscos avaliados 8

III.4.2. $\quad$ Riscos de contratação

III.4.2.1. Contribuição dos sócios $\quad 82$

III.4.2.2. Integralização da cont ribuição 86

III.4.2.3. Limitação da responsabilidade $\quad 88$

III.4.3. Riscos de alocação do poder de decisão 91

$\begin{array}{ll}\text { III.4.3.1. Quoruns deliberativos } & 91\end{array}$

III.4.3.2. Alinhamento prévio de interesses 95

III.4.3.3. Limitação do direito de voto 98

III.4.3.4. Invalidação de deliberações sociais $\quad 102$

$\begin{array}{lll}\text { III.4.4. Riscos de interrupção } & 104\end{array}$

$\begin{array}{lll}\text { III.4.4.1. Custos excessivos de operação } & 104\end{array}$

$\begin{array}{lll}\text { III.4.4.2. Dissociação } & 107\end{array}$

$\begin{array}{lll}\text { III.4.4.3. Dissolução } & 118\end{array}$

IV. CONCLUSÃO

V. BIBLIOGRAFIA 125

$\begin{array}{lll}\text { VI. ANEXOS } & 140\end{array}$

VI.1. Etapas do Negócio de Venture Capital 140

VI.2. Fundos de Investimento: Regime Jurídico Aplicável 157

VI.3. Métodos para Avaliação de Investimentos: Principais Considerações 166

VI.4. Incentivos à Inovação: Fontes de Informação Utilizadas 175 


\section{RESUMO}

Venture capital é espécie de empreendimento que vincula dois agentes econômicos, empreendedor e investidor, visando ao desenvolvimento de uma ideia inovadora para posterior comercialização no mercado. $\mathrm{O}$ empreendedor é detentor de conhecimento sobre a ideia e o investidor possui os recursos para desenvolver o projeto.

O negócio se diferencia dos demais pelo alto grau de incerteza e risco do empreendimento e requer o uso de tipos contratuais adequados para sua limitação.

O projeto se inicia com a etapa de contratação, na qual as partes negociam a divisão de riscos e retorno do negócio, seguindo-se a etapa de monitoramento do desenvolvimento das atividades. Ao final ocorre o desinvestimento, com a saída do investidor e venda do negócio.

Do ponto de vista da Economia, utilizamos a Teoria dos Jogos e apresentamos os problemas informacionais, riscos e incertezas do negócio, e os incentivos para organizar a cooperação entre as partes.

Do ponto de vista de Finanças, debatemos a decisão de financiamento do negócio e as alternativas para diversificação dos riscos do investimento, isto é, a possibilidade de limitação dos riscos pela adoção de estratégias de contenção, que aumentam o interesse em contratar o negócio.

Do ponto de vista do Direito, avaliamos qual a estrutura contratual ideal para organizar esse tipo de empreendimento. Analisamos as principais formas usadas para organização do negócio, em especial as sociedades limitadas e as sociedades anônimas fechadas.

Avaliamos o suporte normativo aplicável, com destaque para a possibilidade de limitação dos riscos do projeto pela aplicação das normas de Direito Societário a esses empreendimentos. 
Os principais riscos aplicáveis são os riscos de contratação do negócio, os riscos de alocação do poder de decisão entre os sócios e os riscos de interrupção prematura do projeto.

Devido à natureza e características do negócio de venture capital, concluímos que esse tipo de projeto é mais bem organizado como um contrato plurilateral e que não há tipo contratual ideal para alinhar os interesses. Dos tipos existentes, a sociedade anôni ma fechada é o mais adequado, mas incapaz de limitar todos os riscos do negócio.

A conclusão é confirmada, parcialmente, pelas evidências empíricas apresentadas.

Palavras-chave: Venture Capital - Direito e Economia - Teoria dos Jogos Finanças Corporativas - Incerteza - Risco - Contrato - Sociedade Limitada Sociedade Anônima Fechada - Fundo de Investimento. 


\begin{abstract}
Venture capital is a business that links two economic agents, entrepreneur and investor, aiming to develop an innovative idea for future sale on the market. The entrepreneur holds knowledge about the idea and the investor has the resources to develop the project.
\end{abstract}

It is distinguished from others by the high degree of uncertainty and risk of the project and requires the use of appropriate contract types for its restriction.

The project begins with the contracting stage, in which the parties negotiate the division of risks and return business, followed by the monitoring of the development of the business activities. At the end occurs the divestment, in which the finished business is sold by the investor.

From the point of view of Economics, we use Game Theory to present the informational problems, business' risks and uncertainties, and the incentives to organize the cooperation between the parties.

From the standpoint of Finance, we discuss the decision to finance the business, and alternatives for risk diversification, that is, the possibility of limiting the risks by adopting containment strategies that may increase the interest in contracting.

From the point of view of Law, we evaluate the ideal contractual structure for organizing this kind of project. We analyze the main existing contract types, in particular, the limited liability companies and the closed corporations.

We present our concerns about the normative support applicable to that type of business, emphasizing the Corporate Law problems.

We evaluate the normative support applicable, emphasizing the possibility of limiting the project' risks by applying the Corporate Law rules to such ventures. 
The main risks are the risks applicable to the contracting phase, the risk of incorrect allocation of decision rights between the partners and the risk of premature termination of the project.

Due to the nature and characteristics of the venture capital business, we conclude that this type of design is best organized as a plurilateral agreement and that there is no contract type that can be considered ideal to align the interests. Considering all the existing types, the private corporation contract is the most appropriate form, but also unable to limit all the business risks.

The conclusion is partially supported by the empirical evidence presented.

Keywords: Venture Capital - Law and Economics - Game Theory - Corporate Finance - Uncertainty - Risk - Contract - Limited Liability Company - Closed Corporation - Investment Fund. 


\section{RÉSUMÉ}

Le capital-risque est une entreprise qui relie deux agents économiques, entrepreneur et investisseur, qui visent à développer une idée innovatrice pour vente future sur le marché. L'entrepreneur détient les connaissances sur l'idée et l'investisseur dispos des ressources nécessaires pour développer le projet.

Il se distingue des autres par le degré élevé d'incertitude et de risque du projet et demande l'utilisation de types de contrats appropriés d'atténuation.

Le projet commence par la phase de négociation des contrats, dans lequel les parties négocient le partage des risques et le retour, suivi de par la phase de surveillance de l'évolution de l'entreprise. Enfin le désinvestissement se produit et l'investisseur vend l'entreprise.

Du point de vue de l'Économie, nous utilisons la Théorie des Jeux à présenter les problèmes d'information, des risques et des incertitudes de l'entreprise, et les incitations à organiser la coopération entre les parties.

Du point de vue des Finances, nous discutons de la décision de financer l'entreprise, et des alternatives pour la diversification des risques d'investissement, à savoir, la possibilité d'adoption des stratégies pour limiter les risques, qui augmentent l'intérêt de signer l'accord.

Du point de vue de l'Droit, nous évaluons la structure contractuelle idéale pour l'organisation de ce type de projet. Nous analysons les principaux types de contrats applicables, en particulier, les sociétés à responsabilité limitée et les sociétés fermées.

Nous évaluons la construction normative applicable, mis en évidence par la possibilité pour limiter les risques du projet par les règles du Droit des Sociétés telles entreprises.

Les principaux risques sont les applicables a l'embauche du contrat, la 
répartition des risques de pouvoir de décision entre les partenaires et le risque de rupture prématuré du projet.

En raison de la nature et les caractéristiques de l'activité de capital-risque, nous concluons que ce type de projet est mieux organisé comme un accord plurilatéral et qu'il n'exister pas d'type contractuel idéal à aligner les intérêts. De types existants, une société privée est la plus appropriée, mais incapable de limiter toutes les risques d'entreprise.

La conclusion est confirmée, en partie, par les données empiriques présentées.

Mots-clés: Capital-risque - Venture Capital -Droit et Economie - Théorie des Jeux - Finance d'Entreprise - Incertitude - Risque - Contrat- Société à Responsabilité Limitée - Société Anonyme Fermée - Fond d'investissement. 


\section{INTRODUÇÃO}

\section{I.1. Apresentação e delimitação do te ma}

Os textos em epígrafe, de VINCENZO ROPPO e RONALD COASE, resumem o enfoque desta tese a respeito de negócios de venture capital, também denominados de capital empreendedor ${ }^{1,2,3,4}$.

O primeiro texto, de COASE, faz referência a escrito clássico de sua autoria, intitulado "The Problem of Social Cost", de 1960. O autor chama a atenção para a necessidade de primeiro observar o "mundo real" para, em seguida, elaborar construções teóricas. Explica que os custos de transação ${ }^{5}$ influenciam a tomada de

\footnotetext{
${ }^{1}$ Optamos pelo uso da expressão em língua inglesa, por ser mais conhecida pelos pesquisadores e profissionais.

${ }^{2}$ Private equity define-se como negócio voltado a investimentos em empreendimentos de maior risco e potencial de crescimento, visando obter a maior rentabilidade possível. Dentre as subespécies existentes, destacam-se: a) venture capital: investimentos em empreendimentos pequenos e inovadores, com alto grau de incerteza, visando sua expansão com objetivo de valorizá-los para venda futura no mercado; b) private equity (stricto sensu): investimentos de menor risco em negócios de maior porte já estabelecidos; c) compra alavancada (leveraged buy-out): operação de compra de controle de uma sociedade, ou de parte significativa das ações com direito de voto; d) reorganização de operações: investimento em recuperação de empresas em crise, realizado com o objetivo de de volvê-las a patamares razoáveis de lucratividade, para venda futura do negócio. A distinção apresentada pela literatura especializada é imprecisa e os problemas analisados nesta tese aplicam-se, em maior ou menor proporção, às diversas categorias de negócios. A estrutura do mercado de venture capital é mais complexa que a adotada nessa tese, conforme se depreende de: Fundação Getúlio Vargas (GVCEPE). A indústria de private equity e venture capital - segundo censo brasileiro. $1^{\mathrm{a}} \mathrm{Ed}$., Março/2011. Disponível em: <http://gvcepe.com/>. Acesso em: 03.04.2012, pp. 67-119.

${ }^{3}$ Não fazemos distinção entre os conceitos de "capital semente" ( seed capital), startup e venture capital. "Capital semente" é forma de investimento em empreendimento inovador em fase pré-operacional, isto é, em estágio embrionário, ainda incapaz de gerar fluxo de caixa para manter o negócio em funcionamento. Normalmente, origina-se de recursos de parentes, amigos, "investidores-anjos" e outras formas diretas de financiamento, como por exemplo, crowdfunding, este definido como a venda de pequena quantidade de cotas ou ações a uma grande variedade de investidores, normalmente por meios eletrônicos. Startup é investimento em negócios já em fase mais avançada, porém com produtos e serviços ainda não finalizados para comercialização no mercado. A distinção pode se dar pelo porte do investimento, complexidade dos contratos, grau de risco, nível de maturação dos produtos e serviços, etc. Optamos por usar a expressão "venture capital" para fazer referência às três formas indicadas. Para detalhamento, ver: Fundação Getúlio Vargas (GVCEPE). A indústria de private equity e venture capital - segundo censo brasileiro. $1^{\mathrm{a}} \mathrm{Ed}$., Março/2011. Disponível em: <http://gvcepe.com/>. Acesso em: 03.04.2012, pp. 70-71.

${ }^{4}$ FORTUNA aponta classificação distinta, que associa fundos de investimento em participação a negócios de private equity, indicando serem estes também denominados fundos de seed capital, que toma por sinônimo de fundos de venture capital, para fazer referência a investimentos embrionários em sociedades fechadas de alto potencial e risco. O autor aponta ainda a existência do "fundo mezanino", com carteira de investimentos mais flexível que a apresentada pelos fundos de private equity. (FORTUNA, Eduardo. Mercado financeiro produtos e serviços. $18^{\mathrm{a}}$ ed., Rio de Janeiro: Qualitymark, 2010, pp. 605-608).

${ }^{5}$ Custos de transação são os incorridos pelas partes para participarem do negócio. Em venture capital, correspondem aos custos de identificação das partes contratantes, pesquisa, contratação, monitoramento e administração do negócio. COASE entende que os custos de transação dependem do tratamento jurídico
} 
decisão pelos agentes econômicos e não podem ser desconsiderados. Para ele, a lei e a justiça são instituições sociais ${ }^{6}$ que atribuem direitos e deveres com o objetivo de redução dos custos de transação, aumentando o bem-estar social.

O segundo texto de COASE explica sua visão a respeito de como abordar o problema. O autor parte de exemplo exaustivamente repetido em livros-texto de Economia sobre qual seria a melhor forma de organizar a operação de faróis de sinalização para navios que trafegam na costa. Os livros-texto apresentam argumentos para exemplificar um serviço cuja prestação seria de exclusividade do Estado, porque seria impossível aos particulares estabelecer maneira eficiente de cobrar por serviços de iluminação e sinalização prestados à distância, uma vez que os comandantes e proprietários dos navios sempre poderiam ignorar a cobrança. COASE demonstra que o exemplo não se fundamenta em fatos, pois a administração de faróis, na Inglaterra, é conduzida há séculos pela iniciativa privada, e de forma lucrativa. O exemplo permite criticar a postura de afastamento da realidade e a busca de soluções teóricas que não consideram os fatos.

Em linha com o pensamento de COASE, nossa abordagem parte de elementos coletados na prática negocial do mercado de venture capital, para buscar soluções que viabilizem seu desenvolvimento.

O outro texto em epígrafe, de autoria de ROPPO, inspira-nos a realizar esforço na tentativa de buscar a "veste jurídica" ideal para esse tipo de negócio. Como ensina ROPPO, é essencial iniciar pela compreensão da operação econômica para, então, selecionar a estrutura jurídica ("veste”) mais adequada para organizá-lo.

aplicado, isto é, da atribuição de direitos e deveres aos agentes econômicos. Os custos de transação são de difícil mensuração, mas é possível observar as escolhas finais dos agentes, que são medidas indiretas de avaliação. (COASE, Ronald. "The nature of the firm”. In The firm, the market, and the law. Chicago: University of Chicago Press, 1990, pp. 153-156). São exemplos de custos de transação: busca de parceiros de negócio, procura pelos insumos, comparação de preços, etc. (SZTAJN, Rachel. Direito e Economia dos contratos. Os conceitos fundamentais. In: VERÇOSA, Haroldo M. D. Curso de direito comercial. São Paulo: Malheiros, Vol. 4, 2011, p. 82).

${ }^{6}$ No sentido adotado por essa tese, instituições são as regras do jogo na sociedade e correspondem a restrições impostas aos agentes econômicos. Servem para reduzir a incerteza nas interações entre os agentes na medida em que criam estruturas para coordenar as escolhas individuais. Instituições podem ser formais ou informais e conter permissões ou proibições de conduta. (NORTH, Douglass C. Institutions, institutional change and economic performance. New York: Cambridge University Press, 2002, pp. 3-4). 
A base dos negócios de venture capital é o desenvolvimento da inovação. Normalmente, são empreendimentos novos que apresentam alto grau de incerteza e dificuldade para obter financiamento pela via do mercado de crédito tradicional, devido ao fato de não possuírem histórico de informações de crédito ou bens para oferecer em garantia ${ }^{7}$.

Projetos inovadores dificilmente serão concretizados sem que os recursos necessários ao seu desenvolvimento sejam ofertados aos empreendedores. A solução para viabilizá-los exige recursos obtidos de investidores com maior propensão à tomada de risco, que em contrapartida esperam receber remuneração adequada pelo investimento realizado.

A oferta de recursos depende da existência de uma estrutura institucional que permita alcançar razoável segurança e previsibilidade jurídicas, visando a maximizar as possibilidades de obter retorno positivo sobre o investimento. Nesse sentido, é de fundamental importância a existência de suporte normativo adequado que viabilize a estruturação e condução de negócios sujeitos a alto risco de insucesso.

A organização desses empreendimentos passa, necessariamente, pela estruturação dos contratos que organizem o negócio jurídico ${ }^{8}$ a partir das características da operação econômica, definam a cooperação entre as partes e limitem os riscos existentes.

Por isso, essa tese analisa, principalmente, se há suficiente flexibilidade nos tipos contratuais legais para viabilizar a organização dos projetos. É preciso

\footnotetext{
${ }^{7}$ GOMPERS e LERNER indicam que, em períodos com altas taxas de juros reais da economia, os investimentos em venture capital são mais atrativos para os empreendedores, pois a diferença entre as taxas de juros de mercado e a remuneração do investidor é relativamente menor. Argumentam que, se a disponibilidade de financiamento bancário fosse fator relevante na determinação de investimentos em venture capital, então seria de se esperar que os investimentos aumentassem quando diminui a disponibilidade de financiamento bancário. Entretanto, ao analisarem o período entre o final da década de 1980 e o início da década de 1990, quando houve declínio do crédito bancário, os autores também encontraram declínio dos investimentos em venture capital, o que contraria a previsão teórica. (GOMPERS, Paul A.; LERNER, Josh. The venture capital cycle. $2^{\text {nd }}$ ed., Cambridge: MIT Press, 2006, pp. 60-61).

${ }^{8}$ Negócio jurídico (artigo 104 do Código Civil) é a relação jurídica estipulada entre sujeitos de direito que visa estabelecer direitos e obrigações, adotando forma prevista ou não proibida pela legislação.
} 
compreender os incentivos positivos e negativos para a adoção dos tipos legais estudados e a possibilidade de criar tipos novos ou mistos.

Além disso, o desenvolvimento da venture capital requer a implantação de políticas públicas e legislação de proteção e incentivo à inovação. Apesar do alto impacto gerado pela legislação de incentivos ${ }^{9}$, o tema é apenas brevemente mencionado, por não ser escopo desta tese, que prioriza os aspectos relativos ao direito societário.

Os negócios de venture capital têm sido entendidos como "experimentos" ideais para testar as teorias existentes ${ }^{10}$. As principais características que tornam esses projetos interessante objeto de estudo são: 1) estruturação sob a forma jurídica de sociedades fechadas simplificadas, não sujeitas à complexidade do mercado de valores mobiliários; 2) as partes do negócio, investidor e empreendedor, comportam-se como "agentes individuais", permitindo desconsiderar o estudo dos problemas de ação coletiva $^{11}$; 3 ) os projetos são normalmente voltados para o desenvolvimento de uma única atividade principal, limitando a complexidade de análise; 4) não há informação histórica sobre os negócios, eliminando a necessidade de explicar períodos anteriores à análise.

Esta tese pretende responder às seguintes perguntas:

- O que é o negócio de venture capital?

- Como a operação econômica é estruturada?

- Quais os principais riscos existentes para organizar a cooperação entre as partes e desenvolver as atividades?

\footnotetext{
${ }^{9}$ Breves considerações apresentadas nos Anexos VI.2 e VI.4.

${ }^{10}$ HART, Oliver. Financial contracting. Journal of Economic Literature, vol. 39, N. 4, Dez. 2001, Disponível em: <http://www.jstor.org/stable/2698520>. Acesso em: 07.09.2010, pp. 1084-1085.

${ }^{11}$ Nesse caso, um conjunto de indivíduos beneficia-se coletivamente de determinada ação, mas os custos da ação não são proporcionalmente distribuídos entre eles. Racionalmente, escolhe-se realizar a ação coletivamente e compartilhar custos, porém, nem sempre a melhor solução é alcançada porque há possibilidade de adoção de comportamento oportunista visando a obter parcela maior dos benefícios, sem incorrer proporcionalmente nos custos.
} 
- Qual o grau de adequação da legislação existente para limitar os riscos desses projetos?

- Quais são os tipos legais "ideais" para organizar o empreendimento, alcançar maior segurança jurídica e viabilizar o desenvolvimento das atividades?

\section{I.2. Metodologia utilizada}

Do ponto de vista metodológico, utilizamos conhecimentos multidisciplinares de Direito, Teoria dos Jogos, Análise Econômica do Direito e Finanças.

Em relação ao Direito, avaliamos os tipos contratuais mais adequados, realizando análise crítica a respeito de sua aplicabilidade, com o objetivo de buscar a solução "ideal” para organizar negócios de venture capital. Enfocamos, principalmente, as incertezas e riscos do negócio e a possibilidade de sua limitação pelo contrato que organiza a cooperação entre as partes.

Enfocamos os empreendimentos de venture capital do ponto de vista do Direito Societário e não detalhamos os aspectos relativos a direito de propriedade imaterial, tributário, trabalhista ou previdenciário. Também não empreendemos análise do ponto de vista de direito comparado e recorremos a exemplos estrangeiros somente quando relevantes para a compreensão dos temas tratados.

Quanto à Análise Econômica do Direito, partimos da Teoria da Escolha Racional, na qual agentes racionais e autointeressados fazem escolhas a partir de suas preferências, porém limitados por restrições. Com base nos modelos teóricos existentes, descrevemos os principais problemas informacionais, buscando compreender a melhor 
maneira de organizar, de forma racional ${ }^{12,13}$, a cooperação entre as partes, a alocação de riscos e distribuição de retornos.

Utilizamos a Teoria dos Jogos para analisar comportamentos estratégicos e o impacto dos incentivos positivos e negativos ${ }^{14}$ nas decisões das partes envolvidas em negócios de venture capital. A Teoria dos Jogos estabelece um conjunto de modelos para analisar situações de cooperação e conflito ${ }^{15}$ e o impacto dos incentivos nas decisões estratégicas de agentes que interagem.

Empregamos conceitos de Finanças para estudar a aplicação de métodos para avaliação e decisão de investimento em negócios de venture capital. Também emprestamos da disciplina de Finanças os elementos para avaliar as formas de limitação dos riscos do projeto.

Estudamos as Instruções e Deliberações da CVM aplicáveis a negócios de venture capital e aos fundos de investimento que os organizam, com destaque para os Fundos de Investimento em Empresas Emergentes (FIEE) e os Fundos de Investimento em Participações (FIP).

\footnotetext{
${ }^{12}$ FIANI entende que racionalidade é coerência entre os fins colimados e os meios empregados para atingilos. O indivíduo altruísta é racional, assim como o egoísta, dependendo dos objetivos definidos. Racionalidade refere-se aos meios empregados para alcançá-los. Agente racional é aquele que: aplica a lógica das premissas para obter conclusões; utiliza premissas justificadas, isto é, adequadas aos meios empregados; usa evidências empíricas imparciais para julgar afirmações sobre fatos. (FIANI, Ronaldo. Teoria dos jogos. $2^{\mathrm{a}}$ ed., São Paulo: Campus, 2006, pp. 21-22).

${ }^{13} \mathrm{O}$ comportamento dos agentes é orientado pelas noções de racionalidade limitada e oportunismo. A racionalidade limitada é aquela reduzida por fatores externos, diminuindo a cognição do agente nas interações com os outros. Oportunismo é o comportamento que orienta a busca do interesse próprio, que pode ser socialmente indesejado quando há uso de distorção ou sonegação de informações e esforços para enganar, dissimular ou confundir o outro. (WILLIAMSON, Oliver. The economic institutions of capitalism. New York: Free Press, 1987, pp. 44-49). Indivíduos escolhem alternativas que maximizam a utilidade pessoal e sociedades optam pelas que maximizam lucros. Racionalidade, ou busca pelo interesse próprio, contrasta com a noção de razoabilidade do direito, isto é, o comportamento pode ser racional, ainda que esteja em conflito com normas sociais vigentes. (MERCURO, Nicholas; MEDEMA, Steven G. Economics and the law. Princeton: Princeton University Press, 1997, p. 57).

${ }^{14}$ Incentivo positivo (encorajamento) e negativo (desencorajamento) conforme propostos por BOBBIO para organizar a função promocional do direito. (BOBBIO, Norberto. Da estrutura à função: novos estudos de teoria do direito. São Paulo: Manole, 2007, pp. 13-17; 23-24).

${ }^{15} \mathrm{Na}$ cooperação, as partes com interesses em comum conseguem coordenar esforços para agir em conjunto, visando a obter benefícios que serão compartilhados. No conflito, os incentivos ou interesses deixam de estar alinhados, produzindo comportamentos oportunistas ou mudanças nas regras de repartição dos custos e benefícios da atividade em comum. A teoria dos jogos define formas de lidar com cooperação e conflito e analisa decisões tomadas em situações nas quais os agentes interagem, orientando a escolha de estratégias. Pressupõe a aplicação de regras lógicas ao processo de decisão quando há interação das partes.
} 
Como referências empíricas, utilizamos o Segundo Censo Brasileiro da Indústria de Private Equity e Venture Capital, de 2011, realizado pela Fundação Getúlio Vargas (GVCEPE) ${ }^{16}$, que apresenta visão abrangente e atual sobre o tema proposto. Também analisamos os documentos produzidos pela Latin America Venture Capital Association (LAVCA), em especial, o Venture Capital Scorecard ${ }^{17}$, o Guia para Term Sheet e os modelos de contratos recomendados por essa associação ${ }^{18}$, e outros estudos específicos ${ }^{19}$.

Complementamos estas fontes com informação obtida a partir de entrevistas realizadas com participantes do mercado de venture capital, com o objetivo de buscar dados empíricos sobre os contratos efetivamente concluídos no país.

\section{I.3. Justificativa para a escolha}

Negócios de venture capital têm sido pouco estudados no Brasil, apesar de serem de interesse de operadores do direito, economistas e administradores de empresas. Há teorias que tentam explicar sua estrutura e funcionamento ${ }^{20}$, mas

\footnotetext{
${ }^{16}$ Fundação Getúlio Vargas (GVCEPE). A indústria de private equity e venture capital - segundo censo brasileiro. $1^{\text {a }}$ Ed., Março/2011. Disponível em: <http://gvcepe.com/〉. Acesso em: 03.04.2012.

${ }^{17}$ LAVCA (Latin America Venture Capital Association). The private equity and venture capital environment in Latin America - Scorecard, 2012. Disponível em: 〈www.lavca.org〉. Acesso em 19.02.2013.

${ }^{18}$ LAVCA (Latin America Venture Capital Association). Guia para term sheets de venture capital e private equity, 2012. Disponível em: 〈www.lavca.org>. Acesso em 19.02.2013; Guia para contratos de venture capital e private equity, 2012. Disponível em: 〈www.lavca.org〉. Acesso em 19.02.2013.

${ }^{19}$ Indicados no Anexo VI.4.

${ }^{20}$ A Teoria de Estrutura de Capital preocupa-se com a combinação entre o uso de empréstimos e valores mobiliários para financiar o negócio. (MODIGLIANI, Franco; MILLER; Merton H. The costs of capital, corporate finance, and the theory of investment. American Economic Review, n. 48, June/1958, pp. 261-297; MODIGLIANI, Franco; MILLER; Merton H. Corporate income taxes and the cost of capital: a correction. American Economic Review, n. 53, June/1963, pp. 433-443; MILLER, Merton H. Leverage. In ADLER, Barry E. Foundations of bankruptcy law. New York: Foundation Press, 2005). Os problemas de agenteprincipal enfatizam o alinhamento de incentivos entre os agentes econômicos. (JENSEN, Michael C. Agency costs of free cash flow, corporate finance, and takeovers. American Economic Review, May 1986, Vol. 76, No. 2, pp. 323-329. Disponível em: <http://papers.ssrn.com/paper.taf?abstract_id=99580>. Acesso em: 11.03.2011; JENSEN, Michael C.; MECKLING, William H. Theory of the firm: managerial behaviour, agency cost and ownership structure. Journal of Financial Economics, v. 3, n. 4, 1976, pp. 305-360. Disponível em: <http://papers.ssrn.com/sol3/paper.taf?abstract_id=94043>. Acesso em: 15.05.2006; FAMA, Eugene F.; JENSEN, Michael C. Agency problems and residual claims. Journal of Law \& Economics, Vol. XXVI (June 1983). Disponível em: <http://papers.ssrn.com/paper.taf?abstract_id=94032>. Acesso em: 11.03.2011). A Teoria dos Custos de Verificação avalia os riscos do investimento e elabora elementos para controle do negócio. Esta evoluiu para a Teoria do Direito de Controle e Decisão, ou Teoria do Custo de Monitoramento, na qual o direito das partes pode ser contingente em relação a medidas observáveis de
} 
nenhuma, isoladamente, tem sido capaz de apresentar soluções suficientes. Também não identificamos estudos jurídicos que analisem os impactos da utilização de tipos contratuais para organizar negócios de venture capital.

Pretendemos contribuir para a literatura existente com a construção de visão sistematizada sobre o tema do ponto de vista das instituições brasileiras, buscando aproximações e distanciamentos entre as teorias existentes, os tipos contratuais utilizados e os negócios efetivamente realizados.

Também entendemos haver contribuição para caracterização, avaliação e análise crítica dos tipos contratuais aptos para organizar negócios de venture capital, bem como recomendação do tipo "ideal” para limitação dos principais riscos relativos a esse tipo de empreendimento.

\section{I.4. Plano da tese}

A tese é desenvolvida em quatro capítulos.

O capítulo I é dedicado a essa introdução.

O capítulo II conceitua o negócio de venture capital e apresenta suas principais características, incentivos e riscos. Também são discutidos os elementos que caracterizam o negócio jurídico e as principais características dos contratos que organizam a cooperação entre as partes.

O capítulo III apresenta análise crítica a respeito dos principais tipos contratuais predispostos na legislação, potencialmente aptos a organizar os empreendimentos. Para os tipos selecionados, que são a sociedade limitada e a anôni ma fechada, avaliamos sua adequação às características do negócio, do ponto de vista dos principais riscos

desempenho do negócio. (HART, Oliver. Financial contracting. Journal of Economic Literature, vol. 39, N. 4, Dec., 2001, Disponível em: 〈http://www.jstor.org/stable/2698520>. Acesso em: 07.09.2010, pp. 10791100; TOWSEND, Robert M. Optimal contracts and competitive markets with costly state verification. Journal of Economic Theory, Vol. 21, N. 2 (Oct., 1979), pp. 265-293. Disponível em: <http://www.robertmtownsend.net>. Acesso em: 01.02.2012). 
existentes e das condições para sua limitação. Os riscos são organi zados e classificados em grupos que guardam afinidade com os principais problemas encontrados, que são de três categorias: contratação do negócio; alocação do poder de decisão entre os sócios; interrupção do projeto. Descartamos, justificando a decisão, os outros tipos contratuais predispostos na legislação, em especial o mútuo, consórcio de sociedades, associações e demais tipos societários.

O capítulo IV apresenta um quadro-resumo contendo a comparação entre os dois tipos contratuais analisados e nossas conclusões a respeito da possibilidade de limitação dos riscos do negócio de venture capital pelos tipos estudados. 


\section{DEFINIÇÕES E CONCEITOS APLICÁVEIS}

\section{II.1.Negócio de venture capital}

\section{II.1.1. Definição}

Negócios de venture capital são empreendimentos que têm por objetivo desenvolver ideia inovadora de conhecimento do empreendedor, que é o criador da ideia, com aporte de recursos do investidor. Refere-se à associação de agentes econômicos que se propõem a organizar atividades de alto grau de incerteza visando ao desenvolvimento de ideia ou invenção com valor econômico, para posterior comercialização no mercado.

A locução "venture capital" incorpora os dois aspectos mencionados: o alto grau de incerteza da atividade (venture, ou adventure), que se desenvolve com o uso de recursos (capital).

O negócio se desenvolve em três etapas: contratação, monitoramento e desinvestimento. Na primeira ocorre a negociação entre as partes e a contratação do negócio. Na segunda, as atividades são desenvolvidas e o desempenho do projeto é acompanhado pelos participantes. Na última etapa, de desinvestimento, o investidor retira-se do negócio vendendo sua participação ${ }^{21}$.

Considere-se, por exemplo, um empreendimento para desenvolvimento de novos medicamentos pela indústria farmacêutica. Na primeira etapa do projeto são testados diversos princípios ativos potencialmente aptos à formulação do medicamento. $\mathrm{Na}$ segunda etapa alguns são selecionados para aprofundamento da pesquisa e desenvolvimento dos compostos químicos e outros são descartados. Na terceira etapa, um é selecionado para desenvolvimento e produção experimental, seguido da realização de testes em laboratório. Na quarta etapa, a droga experimental é testada em animais. Na quinta etapa são realizados testes controlados em humanos. Na sexta etapa,

\footnotetext{
${ }^{21}$ As principais etapas do desenvolvimento do negócio são detalhadas no Anexo VI.1.
} 
o medicamento é submetido ao registro e aprovação pelos órgãos reguladores. Na sétima e última etapa há produção em larga escala e comercialização no mercado. $\mathrm{O}$ projeto hipotético é de alta complexidade, pode perdurar por vários anos e consumir recursos significativos, havendo inúmeras possibilidades de insucesso, decorrentes de inviabilidade técnica da formulação do medicamento, fracasso dos testes com animais ou humanos, altos custos de desenvolvimento e produção, reprovação pelos órgãos reguladores, etc.

O exemplo explicita a principal diferença entre negócios de venture capital e outras formas de organização de projetos: o maior grau de incerteza e riscos associados ao empreendimento.

A incerteza decorre da ausência de referências ou informação suficientes sobre o desenvolvimento da ideia inovadora, que leva a falta de conhecimento sobre a expectativa de resultados futuros da atividade. Há somente avaliação subjetiva (percepção) dos riscos potenciais, podendo ocorrer, a qualquer momento e independente da vontade das partes, eventos imprevisíveis que inviabilizem o negócio.

Em consequência, há também maior expectativa de compensação das partes pelos altos riscos envolvidos, isto é, de obtenção de retorno mais elevado sobre o investimento em projeto bem sucedido.

\section{II.1.2. Elemento diferenciador: incerteza e risco}

Incerteza é dúvida, imprevisibilidade, desconhecimento a respeito dos resultados possíveis de determinada atividade. Significa inadequação da ideia imaginada a priori aos fatos objetivos posteriores. Em contraste, certeza é confirmação de que a ideia preconcebida pode ser comprovada posteriormente por fatos objetivos.

A incerteza sempre está presente em negócios de venture capital. Há dúvidas a respeito do desenvolvimento da ideia, capacidade de execução do projeto, viabilidade de produção e comercialização dos produtos e serviços, interesse do mercado, mudanças na concorrência e na preferência dos consumidores. O desenvolvimento da 
inovação sempre estará sujeito à incerteza.

A incerteza difere do risco por sua imprevisibilidade. Em situação de incerteza não podemos antever os problemas a serem solucionados e os resultados a serem alcançados, mas em situação de risco podemos avaliá-los, ainda que se faça uso de suposições e estimativas. Por isso, KNIGHT explica que o risco é quantificável, mas a incerteza não é. Quando há risco, há informação mensurável, fundamentada em critérios objetivos de avaliação ${ }^{22}$. Ao contrário da incerteza, em situação de risco é possível escolher uma configuração ("estado") mais provável do projeto que seja apta a alcançar o resultado esperado, isto é, pode haver uma forma de organização das atividades que tende a apresentar maiores possibilidades de sucesso que as demais.

Incerteza é a impossibilidade de avaliar, em bases objetivas, a probabilidade de sucesso ou fracasso do empreendimento, antecipar os entraves ao desenvolvimento das atividades e o retorno esperado. As diversas configurações possíveis para organizar o projeto podem levar a inúmeros resultados potenciais, tornando mais difícil a escolha da melhor alternativa ${ }^{23}$.

A incerteza pressupõe haver informação subjetiva, isto é, que depende exclusivamente da experiência dos agentes envolvidos. Decorre da ausência de conhecimento objetivo sobre as condições do negócio e da dificuldade em qualificar, medir e revelar a informação incompleta e imperfeita ${ }^{24}$. Significa que há múltiplas

\footnotetext{
22 "But Uncertainty must be taken in a sense radically distinct from the familiar notion of Risk, from which it has never been properly separated. (...). The essential fact is that "risk" means in some cases a quantity susceptible of measurement, while at other times it is something distinctly not of this character; and there are far-reaching and crucial differences in the bearings of the phenomenon depending on which of the two is really present and operating. (...) It will appear that a measurable uncertainty, or "risk" proper, as we shall use the term, is so far different from an unmeasurable one that it is not in effect an uncertainty at all. We shall accordingly restrict the term "uncertainty" to cases of the non-quantitative type. It is this "true" uncertainty, and not risk, as has been argued, which forms the basis of a valid theory of profit and accounts for the divergence between actual and theoretical competition". (KNIGHT, Frank H. Risk, uncertainty and profit. 1921. Disponível em: 〈www.econlib.org>. Acesso em: 04.06.2012, p. I.I.26).

${ }^{23}$ SANDRONI indica que há incerteza quando, a partir de determinado conjunto de ações, pode-se chegar a vários resultados possíveis, pois as probabilidades esperadas para os resultados não são conhecidas. Caso as probabilidades passem a ser conhecidas, a incerteza transforma-se em risco, que é mensurável e controlável. (SANDRONI, Paulo. Dicionário de Economia. $3^{\text {a }}$ ed., São Paulo: Best Seller, 1994, p. 168).

${ }^{24}$ GINTIS indica que o equilíbrio é difícil de ser obtido na presença de informação imperfeita e incompleta, pois há informação detida com exclusividade por uma das partes e não revelada à outra. Nesse tipo de jogo há muitos equilíbrios não plausíveis e poucas formas de rejeitá-los, pois os conjuntos de informação são difusos e de difícil avaliação. Tal situação pode induzir o agente a erro na escolha da solução, ou a escolher
} 
possibilidades de abordar o projeto e não há maneira única de medir seu desempenho, dificultando a eliminação de alternativas indesejadas pelas partes.

A incerteza impacta a coordenação entre os agentes, altera a motivação para contratar e afeta a capacidade de tomar decisões bem informadas ${ }^{25}$. Mesmo que haja expectativa de retorno significativo sobre o investimento, os interessados podem recusar a participação no projeto, porque não conseguem identificar, avaliar e limitar os riscos de tomar parte no negócio. A incerteza dificulta a correta avaliação do empreendimento, podendo levar os agentes a incorrer em erros de decisão.

Risco, da mesma forma que incerteza, é a possibilidade de dano ou sucesso, um acontecimento eventual cuja ocorrência pode não depender da vontade dos envolvidos, mas que afeta o resultado esperado ${ }^{26}$.

Risco é conhecimento sobre as probabilidades objetivas de determinado evento, as quais podem ser mensuradas e limitadas. Ao contrário da incerteza, o risco elimina a subjetividade da avaliação, indicando objetivamente a probabilidade de ocorrência do evento $^{27}$. SANVICENTE esclarece que a incerteza transforma-se em risco quando se

soluções não ideais. (GINTIS, Herbert. Game theory evolving - A problem-centered introduction to modeling strategic interaction. Princeton: Princeton University Press, 2000, p. 286).

${ }^{25}$ Os agentes comportam-se de acordo com a motivação e a habilidade em decifrar o ambiente em que atuam, características que, segundo NORTH, tornam a escolha humana mais complexa do que as previsões feitas pela Teoria da Escolha Racional. A motivação determina o conjunto de condições que compele o indivíduo a agir, influenciado por fatores econômicos e altruísticos. A habilidade em decifrar o ambiente indica a capacidade em entender o contexto situacional em que se encontra, a partir das informações disponíveis (NORTH, Douglass C. Institutions, institutional change and economic performance. New York: Cambridge University Press, 2002, p. 17). A motivação é influenciada pela reputação, confiança e altruísmo. A habilidade em decifrar o ambiente é tanto maior quanto melhores forem as instituições que organizam as trocas econômicas e reduzem as incertezas. O processamento incompleto e subjetivo da informação afeta o processo decisório, criando lacunas entre a capacidade do agente de decifrar o ambiente e a dificuldade em definir preferências. Quanto maior a lacuna, maior a necessidade de padronização para redução de incertezas que se originam da informação incompleta, da complexidade do ambiente e da capacidade cognitiva limitada dos agentes. Regras e procedimentos servem para simplificar o processo, limitando as escolhas disponíveis. (NORTH, Douglass C. Institutions, institutional change and economic performance. New York: Cambridge University Press, 2002, pp. 20-25).

${ }^{26} \mathrm{O}$ senso comum indica que o risco é a probabilidade de ocorrência de um evento negativo, isto é, danoso ao agente. Em Finanças, a definição de risco refere-se à probabilidade de obter um resultado inesperado, diferente das expectativas iniciais do agente econômico. Neste caso, o risco pode ser positivo, isto é, de retorno superior à expectativa de sucesso, ou pode ser negativo, ou seja, inferior ao esperado.

(DAMODARAN, As wath. Finanças corporativas - teoria e prática. Porto Alegre: Bookman, $2^{a}$ Ed., 2004, p. 140).

${ }^{27}$ CAOUETTE, John B.; ALTMAN, Edward I.; NARAYANAN, Paul. Gestão do risco de crédito. Rio de Janeiro: Qualitimark, 2000, p. 3. 
pode fazer a estimativa dessa probabilidade ${ }^{28}$.

O risco pode ser específico do negócio, isto é, não sistemático, ou pode afetar diversos agentes do mercado e, nesse caso, é denominado risco não específico, ou sistemático. O risco específico é inerente ao negócio, enquanto o risco sistemático é aquele que afeta diversos agentes do mercado indistintamente. $\mathrm{O}$ risco também pode ser diversificável ou não. Risco diversificável é a parcela de valor da variação do retorno sobre o investimento derivada de fatores específicos, atribuídos ao negócio, cujos efeitos podem ser atenuados pela diversificação do investimento ${ }^{29}$. A diversificação é estratégia comumente adotada pelos agentes econômicos para reduzir os riscos; por exemplo, investidores do mercado de capitais evitam adquirir ações de companhias participantes de um único setor econômico, evitando a perda significativa de recursos caso o setor apresente desempenho insatisfatório.

A mensuração do risco permite definir a proporção de sua alocação entre os contratantes e avaliar se as alternativas para sua limitação apresentam custos que sejam compatíveis com o retorno esperado.

Em negócios de venture capital mede-se o prêmio de risco associado ao investimento. O prêmio de risco é o retorno obtido pelo investidor, dado o nível de risco aceito por ele. É o resultado da comparação entre o risco-retorno esperado para o projeto e para as alternativas disponíveis. O negócio de venture capital, apesar de mais arriscado, deve apresentar melhor retorno que as outras opções à disposição dos interessados $^{30,31}$.

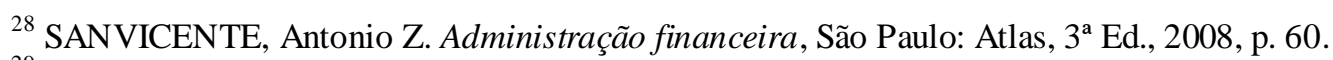

${ }^{29}$ DAMODARAN, Aswath. Finanças corporativas - teoria e prática. Porto Alegre: Bookman, $2^{\text {a }}$ Ed., 2004, pp. 144-145.

${ }^{30}$ A discussão, aqui simplificada, ignorou o fato de o risco ser, ou não, diversificável, isto é, se o investidor pode limitar o risco através de uma carteira balanceada de investimentos em diversos projetos. Ver: PINDYCK, Robert S.; RUBINFELD, Daniel L. Microeconomia. São Paulo: Pearson - Prentice Hall, $6^{\text {a }}$. Ed., 2006, p. 480.

${ }^{31}$ Há diversos modelos usados para avaliar a formação dos preços dos ativos de capital. Entre eles, o modelo CAPM (Capital Asset Pricing Model), que mede o prêmio de risco do projeto, comparando-o com o retorno esperado para o mercado como um todo. O problema é que o modelo CAPM serve para o mercado de ações e, muitas vezes, o negócio de venture capital é organizado como sociedade fechada, sofrendo menor influência do mercado. Ver: PINDYCK, Robert S.; RUBINFELD, Daniel L. Op.cit., pp. 480-482. Como o negócio de venture capital é inovador e incerto, sua comparação com o valor de outros investimentos no mercado não é significativa. O problema permanece mesmo quando são aplicados outros modelos, como o 
Em venture capital, a relação risco-retorno, e não somente a existência de riscos ou incerteza, define o interesse das partes em negociar. Nesses empreendimentos, espera-se que o retorno sobre o investimento compense a assunção de maiores riscos.

\section{II.2. Características dos contratos}

\section{II.2.1. Sujeitos e interesses}

\section{II.2.1.1. Sujeitos}

Há duas partes no negócio de venture capital, empreendedor e investidor.

O empreendedor normalmente é um cientista ou especialista técnico detentor de conhecimento exclusivo sobre a ideia inovadora.

O termo "empreendedor" é utilizado em sentido restrito, para designar o criador da ideia inovadora. Não o empregamos para identificar o empresário, pois, neste caso, incluiria o empreendedor e também o investidor.

O investidor pode ser pessoa natural ou jurídica que tenha recursos financeiros disponíveis. Adicionalmente, ele pode aportar capacidade gerencial ao projeto, pois possui experiência administrativa ${ }^{32}$. $\mathrm{O}$ investidor conhece as condições do mercado, os potenciais compradores do negócio e as características dos consumidores, fornecedores e concorrentes.

\footnotetext{
WACC (Weighted Average Cost of Capital, ou Custo Médio Ponderado de Capital), que define a taxa de retorno esperada pelos investidores. (DAMODARAN, Aswath. Finanças corporativas - teoria e prática. Porto Alegre: Bookman, $2^{\text {a }}$ Ed., 2004, pp. 472-475).

${ }^{32}$ A literatura especializada em venture capital diverge sobre a validade dessa afirmação, especialmente sobre a qualidade e efetividade da capacidade gerencial e acesso a mercados aportados pelo investidor, assim como sobre a efetividade da dedicação de tempo, pelo investidor, para administração do negócio. Ver, por exemplo: GOMPERS, Paul A.; LERNER, Josh. The venture capital cycle. 2nd ed., Cambridge: MIT Press, 2006, pp. 156-169; GOMPERS, Paul A.; KOVNER, Anna; LERNER, Josh; SCHARFSTEIN, David. Skill vs. luck in entrepreneurship and venture capital: evidence from serial entrepreneurs. July, 2006. Disponível em: <http://papers.ssrn.com/paper.taf?abstract_id=933932>. Acesso em: 20.09.2010.
} 
A terminologia empregada pelo mercado de venture capital varia significativamente, conforme a fonte consultada. De acordo com o Segundo Censo de Venture Capital, realizado pela Fundação Getúlio Vargas (GVCEPE), desse mercado participam organizações gestoras, veículos de investimentos, investidores e "empresas investidas". Investidores fornecem recursos financeiros para compor os veículos de investimento. Organi zações gestoras são encarregadas da administração dos veículos de investimento, cujos recursos são aplicados em "empresas investidas", que são os projetos que fazem parte da carteira do veículo de investimento ${ }^{33}$.

Nesta tese, consideramos equivalentes as expressões "investidor" e "veículo de investimento", que definimos como pessoa natural ou coletiva que investe recursos no projeto de venture capital.

O investidor pode adotar três formas básicas de organização: 1) fundo de investimentos, a forma mais comum; 2) sociedade voltada para participação em outros negócios; 3 ) "investidor-anjo".

A primeira forma - fundo de investimento - é condomínio especial, sem personalidade jurídica, que funciona como um centro de imputação, com direitos e deveres específicos, organizado para captação de recursos de terceiros e aplicação em projetos, visando a obter rentabilidade suficiente para cobrir as obrigações do fundo, remunerar os administradores e devolver, com acréscimos, o capital investido pelos cotistas. Por sua importância em negócios de venture capital, detalhamos em anexo sua forma de organi zação e regime jurídico aplicável ${ }^{34}$.

A segunda forma de organização são as sociedades para participação em outros negócios, que participam diretamente no capital de outras sociedades, as "empresas investidas". Desempenham o mesmo papel dos fundos de investimento, porém estão sujeitas ao regime jurídico das sociedades empresárias.

\footnotetext{
${ }^{33}$ Fundação Getúlio Vargas (GVCEPE). A indústria de private equity e venture capital - segundo censo brasileiro. $1^{a}$ Ed., Março/2011. Disponível em: <http://gvcepe.com/>. Acesso em: 03.04.2012, pp. $72-74$.

${ }^{34}$ Anexo VI.2.
} 
A terceira forma de organização é o "investidor-anjo". Muitas vezes os grandes investidores não se interessam por projetos embrionários, como os de venture capital, por não apresentarem as características e rentabilidade desejadas. Por isso, pode ser necessária a obtenção de recursos junto ao "investidor-anjo", pessoa natural ou jurídica de menor porte, mais próxima do círculo de relacionamentos do empreendedor, que utiliza regras menos rígidas para seleção de investimentos.

\section{II.2.1.2. Interesses}

Os agentes econômicos que tomam parte no projeto são motivados por interesses que, se corretamente alinhados, levam à contratação e adequada execução do negócio. Interesses são as razões que motivam as partes a desenvolver as atividades, influenciam a maneira de conduzir o empreendimento e os incentivos ${ }^{35}$ para cooperação e conflito ${ }^{36}$.

Há três tipos de interesses envolvidos no negócio de venture capital: interesse individual, coletivo e público.

Os interesses individual e público são preexistentes ao interesse coletivo, sendo que este se manifesta somente com a contratação do negócio.

O interesse público refere-se à sociedade civil, coletividade de pessoas que pode ser beneficiada com o desenvolvimento e comercialização da invenção, porque esta melhora o bem-estar geral. O interesse público é generalização do interesse coletivo,

\footnotetext{
${ }^{35}$ Incentivo é prêmio ou punição que faz com que as partes se comportem de acordo com as expectativas definidas em contrato. É forma de induzir o comportamento da outra parte, mediante oferecimento de ganhos ou imposição de perdas decorrentes da prática de atos indesejados. Como o agente responde a incentivos, as regras funcionam como "preços" a pagar pela adoção de determinado comportamento. Indivíduos racionais comparam "preços" da realização da atividade desejada, assumindo as consequências da decisão. (MERCURO, Nicholas; MEDEMA, Steven G. Economics and the law. Princeton: Princeton University Press, 1997, p. 25).

${ }^{36} \mathrm{O}$ conflito é explicitado por BAIRD e HENDERSON com um exemplo: "I was in one board meeting, and I said, 'I started this [company] to do positive things with the world and do good in the Amazon, not necessarily to get a big payout.' (...) And one of [the Angel investors] looks me in the eye and said, 'Well, the problem is, that you went out and took $\$ 9$ million of other people's money."' (BAIRD, Douglas G.; HENDERSON, M. Todd. Other people's money. John M. Olin Law \& Economics, Working Paper n. 359 $(2 D$ series $)$. September, 2007. Disponível em: 〈http://papers.ssrn.com/paper.taf?abstract_id=1017615>. Acesso em: 11.03.2011, p. 1).
} 
abrangendo interesses de terceiros não diretamente envolvidos com o negócio de venture capital. Orienta-se pela supremacia do bem-estar geral em detrimento do individual ou coletivo. É de interesse público que invenções sejam desenvolvidas, porque melhoram as condições e a qualidade de vida da coletividade.

O interesse coletivo, ou comum, surge com a contratação do negócio e limita a autonomia privada, suplantando os interesses individuais. Fundamenta-se na existência de alto risco do projeto, que exige cooperação entre as partes para consecução do fim comum e obtenção de vantagens mútuas, mesmo que seja necessário sacrificar parte do interesse individual de cada um dos participantes. Em negócios de venture capital são exemplos de interesse comum: 1) a maximização do valor do negócio como um todo e de seu retorno para as partes; 2) a minimização dos riscos do projeto; 3) o respeito às "regras do jogo" na condução do empreendimento ${ }^{37}$. O interesse comum é alcançado através de regras, definidas de comum acordo, para administração do negócio e distribuição do poder de decisão entre os sócios.

$\mathrm{O}$ interesse individual refere-se às preferências das partes isoladamente consideradas. Fundamenta-se na autonomia privada e refere-se ao agente econômico racional e autointeressado que escolhe estratégia que lhe traz maior benefício pessoal, isto é, maximiza ganhos e minimi za perdas individuais.

O interesse individual do empreendedor decorre de sua afinidade pessoal com o projeto, por que este viabiliza a ideia inovadora e materializa seu esforço pessoal, razão pela qual gostaria de devotar a maior quantidade possível de recursos ao projeto. Sua avaliação sobre a probabilidade de sucesso do empreendimento pode ser viesada, porque tende a preferir a continuidade do negócio, mesmo que este se torne inviável. Seu principal incentivo para solicitar a colaboração do investidor decorre do fato de não dispor de recursos suficientes para financiar o projeto. Seu interesse é obter a maior quantidade possível de recursos do investidor, fazendo o mínimo possível de concessões em retribuição. Ele também espera obter participação nos resultados do negócio, normalmente viabilizada pela obtenção de ações ou cotas da sociedade, uma

\footnotetext{
${ }^{37}$ NORTH, Douglass C. Institutions, institutional change and economic performance. New York: Cambridge University Press, 2002, pp. 20-25.
} 
contraprestação por seu esforço no desenvolvimento das atividades.

O interesse individual do investidor é a maximização do retorno sobre os recursos investidos, isto é, a obtenção da maior rentabilidade sobre o investimento realizado. Ele sempre prefere investir a menor quantidade de recursos que lhe traga o maior retorno possível. Compara, racionalmente, a relação risco-retorno de alternativas de alocação de recursos à sua disposição, decidindo, ou não, pelo aporte de recursos ao negócio de venture capital. O investidor não tem afinidade pessoal com o projeto, preferindo interrompê-lo para minimizar perdas, se os riscos superarem o retorno esperado. O investidor também se preocupa com o sucesso do projeto, porque sinaliza sua reputação no mercado e afeta a possibilidade de captar novos recursos de terceiros para aplicar em outros empreendimentos.

Como investimentos dessa natureza costumam ter pouca liquidez e não são negociados em mercado secundário, pode haver dificuldade para vender o negócio durante o desenvolvimento das atividades. Por isso o investidor costuma preferir dividir o projeto em etapas controladas, financiar uma por vez e estabelecer amplas opções de "saída" (desinvestimento), para reduzir sua exposição a perdas (estratégia de stop loss).

Os interesses individuais das partes envolvidas no projeto de venture capital divergem, mas, ainda assim, organiza-se a cooperação porque os participantes entendem que os benefícios do projeto em comum superam os riscos. As principais diferenças de percepção individual referem-se à decisão de continuidade ou interrupção do projeto e à limitação da disponibilização de recursos para seu desenvolvimento, que são as principais fontes de conflito entre as partes.

Os três tipos de interesses, individual, coletivo e público, nem sempre estão alinhados, devendo a lei e o contrato estabelecer mecanismos para viabilizar a coordenação entre os agentes econômicos.

\section{II.2.2. Objeto e finalidade}

O objeto do contrato é o desenvolvimento da inovação, que se refere à 
introdução de invenção, isto é, novas ideias que implantam solução desconhecida para problemas técnicos. Ao final do desenvolvimento, a ideia inovadora será objeto de comercialização. O desenvolvimento da invenção deve resultar em novidade ${ }^{38}$, isto é, novos produtos, processos ou serviços. A novidade refere-se a conhecimento inexistente no estado atual da técnica, isto é, desconhecido da comunidade científica e dos órgãos públicos encarregados da concessão do privilégio de exclusividade sobre a invenção ${ }^{39}$. Consequentemente, não há novidade na mera introdução de aperfeiçoamento em invento preexistente ${ }^{40,41}$, assim como nas patentes de segundo uso, concedidas àqueles que descobrem nova forma de utilização de invenções alheias.

A invenção também deve ser dotada dos requisitos de aplicação industrial e atividade inventiva. A aplicação industrial refere-se à possibilidade de industrialização, isto é, produção para o mercado. A inventividade refere-se à atividade criativa que justifique proteção legal que garanta exclusividade temporária sobre a criação técnica ou a realização de esforços privados para proteção por meio de acordos de sigilo ou segredo industrial ${ }^{42}$.

\footnotetext{
${ }^{38}$ Código de Propriedade Industrial (Lei n. 9.279/96), artigo $8^{\circ}$. "É patenteável a invenção que atenda aos requisitos de novidade, atividade inventiva e aplicação industrial". Artigo 11. "A invenção e o modelo de utilidade são considerados novos quando não compreendidos no estado da técnica. $\$ 1^{\circ} \mathrm{O}$ estado da técnica é constituído por tudo aquilo tornado acessível ao público antes da data de depósito do pedido de patente, por descrição escrita ou oral, por uso ou qualquer outro meio, no Brasil ou no exterior, ressalvado o disposto nos arts. 12, 16 e 17". (...) Artigo 13. "A invenção é dotada de atividade inventiva sempre que, para um técnico no assunto, não decorra de maneira evidente ou óbvia do estado da técnica". Artigo 15. "A invenção e o modelo de utilidade são considerados suscetíveis de aplicação industrial quando possam ser utilizados ou produzidos em qualquer tipo de indústria".

${ }^{39} \mathrm{Em}$ sentido objetivo, a novidade representa conhecimento novo para a coletividade, não compreendido no estado atual da técnica, isto é, desconhecido dos demais membros da sociedade. Obras protegidas por direito de autor devem apresentar somente o requisito de originalidade. Obras protegidas pelo direito de propriedade industrial, como invenções, modelos de utilidade e desenhos industriais, devem, adicionalmente, apresentar o requisito da novidade. (SILVEIRA, Newton. Propriedade intelectual: propriedade industrial, direito de autor, software, cultivares. $3^{\mathrm{a}}$ ed., São Paulo: Manole, 2005, pp. 9; 36).

${ }^{40} \mathrm{O}$ Código de Propriedade Industrial (Lei n. 9.279/96) não define aperfeiçoamento. O aperfeiçoamento pode ser entendido como melhoria funcional ou técnica realizada em invento próprio ou de terceiro, que possibilita a obtenção de certificado de adição de invenção (artigo 76) ou pode autorizar a obtenção de licença compulsória em patente alheia, decorrente de aperfeiçoamento realizado em invento de terceiro (artigo 63).

${ }^{41}$ Da mesma forma, descartamos os direitos sobre sinais distintivos (nome empresarial, marca, nome de domínio, etc.), direitos de autor e, para a maioria das situações, os desenhos industriais e os modelos de utilidade, previstos no Código de Propriedade Industrial (Lei n. 9.279/96). A distinção legal, entretanto, não é nítida, por exemplo, no caso de software (Lei n. 9.609/98), que, pode ser entendido como direito de propriedade industrial ou direito de autor sui generis.

${ }^{42}$ Segredo industrial, ou know-how, é entendido como o conhecimento privado, que não é de domínio público nem de conhecimento dos concorrentes, capaz de produzir diferenciação de uma ideia, produto ou serviço. Sua proteção é contratual, fundamentada no artigo 39 do Acordo TRIPS (Agreement on TradeRelated Aspects of Intellectual Property Rights), que trata dos atos de concorrência desleal (artigo 195 da Lei n. 9.279/96).
} 
O escopo-meio do empreendimento de venture capital inclui a organização da cooperação entre os participantes, com foco nas atividades de desenvolvimento e materialização da ideia inovadora, e também a definição da estrut ura de financiamento do negócio. A organização da cooperação entre os participantes tem como res ultado a materialização da ideia inovadora. A especificação da estrutura de financiamento serve para definir a forma de alocação de recursos ao projeto ${ }^{43}$.

As partes visam a obter direitos de exclusividade para exploração da ideia inovadora. Do ponto de vista dos interesses individual e coletivo, a concessão de privilégio de exclusividade sobre a invenção permite aos participantes recuperar os investimentos realizados e obter lucros com a comercialização da ideia inovadora e de produtos e serviços derivados de sua implantação. Do ponto de vista do interesse público, ao final do período de exclusividade a invenção pode ser produzida e comercializada por outros agentes econômicos sem necessidade de incorrer, novamente, em todos os custos de pesquisa e desenvolvimento, ampliando os benefícios para a coletividade.

O escopo-fim, ou fim comum, é elemento essencial do negócio, devendo, obrigatoriamente, constar do contrato. Ainda que possa haver distintas percepções das partes quanto à forma de condução e financiamento do projeto, o negócio em comum visa a obter maior retorno que as alternativas de alocação de recursos. Por isso, os fins individuais específicos podem divergir, mas o fim comum é único, que é a obtenção de lucro com a comercialização da invenção.

\section{II.2.3. Forma e conteúdo}

A forma contratual é livre, porém o contrato é escrito devido a seu alto grau de

\footnotetext{
${ }^{43}$ Para FORTUNA, o financiamento do projeto é "operação financeira que permite dividir riscos entre o empreendedor e o financiador, os quais são remunerados pelo fluxo de caixa do empreendimento, motivo da operação, após sua implantação". A abordagem permite a adoção de técnicas de financiamento e distribuição de riscos e retorno entre os participantes por meio do isolamento de ativos e passivos no projeto, que são separados dos demais bens e direitos de propriedade dos sócios, para limitar o risco, facilitar o controle do desenvolvimento e a avaliação dos resultados. (FORTUNA, Eduardo. Mercado financeiro - produtos e serviços. $18^{\mathrm{a}}$ ed., Rio de Janeiro: Qualitymark, 2010, pp. 332-334).
} 
incerteza e complexidade. Normalmente é significativa a quantidade de cláusulas estipuladas visando a organizar, de forma minuciosa, a cooperação entre as partes ${ }^{44,45,46}$.

Normalmente o contrato não é levado a registro pelas partes em função da natureza de confidencialidade de seu objeto. Muitas vezes são estipulados acordos visando a evitar a divulgação de informação relevante a terceiros.

Não há tipo contratual predisposto na legislação para reger o negócio de venture capital; a operação deve se adaptar a algum dos tipos existentes. O negócio deve se conformar à estrutura de um contrato "típico", entendido como um modelo de acordo previsto e consolidado pela legislação ao qual se aplicam as regras gerais dos contratos, cabendo às partes definir, caso a caso, as condições específicas do negócio ${ }^{47}$.

As principais cláusulas existentes organizam-se em três grupos: as condições gerais do negócio; as regras para captação e utilização dos recursos; e as estipulações para venda futura do negócio.

\footnotetext{
${ }^{44}$ GOMPERS e LERNER analisaram amostra aleatória de 140 contratos de três investidores e encontraram, na maioria dos casos, contratos complexos com mais de cem páginas de texto. (GOMPERS, Paul A.; LERNER, Josh. The venture capital cycle. $2^{\text {nd }}$ ed., Cambridge: MIT Press, 2006, pp. 72-73).

${ }^{45} \mathrm{Na}$ amostra de casos que analisamos no Brasil há contratos cuja redação ultrapassa 300 páginas, incluindo a carta de intenções (term sheets), o contrato social/estatuto social e o acordo de acionistas.

${ }_{46}$ A literatura de venture capital não é unânime ao considerar a obrigatoriedade de haver contratos complexos para organizar o empreendimento, havendo aqueles que entendem que o prévio relacionamento entre as partes seria suficiente para eliminar sua necessidade. O relacionamento prévio e o grau de confiança entre os envolvidos, definidas como crenças na honestidade esperada da outra parte, indicam a probabilidade de cumprir determinada ação pactuada e influenciam a escolha do arranjo contratual. Contratos podem ser usados para alinhar os incentivos, havendo duas hipóteses: substituição ou complementaridade. A hipótese de substituição sugere que somente há contratos complexos quando não há relacionamento prévio ou há baixo grau de confiança entre as partes. A hipótese de complementaridade sugere que contratos complexos são usados somente quando há relacionamento prévio ou algum grau de confiança estabelecido entre as partes. A distinção entre as duas hipóteses depende da expectativa sobre a execução do contrato. Na primeira, os contratantes acreditam na possibilidade de cumprimento do contrato e evitam negociar contratos complexos, devido ao elevado custo. Na segunda hipótese, as partes acreditam que o contrato não garante o cumprimento voluntário ou forçado das obrigações e, por isso, optam por estruturas contratuais mais simples para reduzir custos, deixando as estruturas mais complexas para situações nas quais já há confiança recíproca, isto é, quando o custo de elaboração do instrumento contratual é justificado pela maior complexidade do negócio e não pela desconfiança mútua. BOTAZZI, DA RIN e HELLMAN sustentam empiricamente a prevalência da hipótese de complementaridade em negócios de venture capital. (BOTAZZI, Laura; DA RIN, Marco; HELLMANN, Thomas. The importance of trust for investment: evidence from venture capital. September, 2010. Disponível em: <http://www.jstor.org/stable/997934>. Acesso em: 27.01.2012).

${ }^{47}$ Conceito de contrato típico apresentado por: SZTAJN, Rachel. Futuros e swaps - uma visão jurídica. São Paulo: Cultural Paulista, 1999, pp. 51-52; 210.
} 
As condições gerais do negócio definem a organização e a estrutura do projeto, direitos e deveres das partes, responsabilidade dos administradores, forma de administração, deliberação e decisão a respeito de matérias críticas para o desenvolvimento do projeto, restrições ou proibições aplicáveis durante a vigência do pacto, forma de distribuição dos lucros ou prejuízos entre os participantes, entre outras.

As regras para captação de recursos de terceiros estabelecem a forma de realização do investimento, isto é, a quantidade e valor da participação de cada sócio, a forma de pagamento da contribuição, a eventual prestação de garantias e a distribuição dos resultados aos sócios e às demais pessoas essenciais ao desenvolvimento das atividades.

As cláusulas contratuais também estabelecem a forma e as condições para avaliação e venda do negócio e impedem a adoção de comportamentos oportunistas ${ }^{48}$ das partes no sentido de dificultar a venda.

Normalmente, os contatos de venture capital estabelecem as seguintes condições contratuais específicas:

- $\quad$ Criação de entidade jurídica autônoma, com separação patrimonial;

- Estrutura organizacional flexível, proporcional ao porte e complexidade do empreendimento, com limitação da responsabilidade dos sócios;

- Contribuição dos sócios, em bens e serviços, para constituição do capital necessário;

- Critérios para partilha dos riscos e retorno do negócio;

\footnotetext{
${ }^{48}$ Oportunismo é o comportamento do agente que orienta a busca do interesse próprio, usando subterfúgios como não revelação, distorção e sonegação de informações, ou atitudes deliberadamente organizadas para enganar, dissimular ou confundir o outro. (WILLIAMSON, Oliver. The economic institutions of capitalism. New York: Free Press, 1987, pp. 44-49).
} 
- Configuração de títulos de participação com finalidade de estabelecer o controle do negócio ou a fruição de benefícios, para distribuição aos sócios e empregados;

Alocação do poder de decisão entre os sócios visando a minimizar a incerteza do negócio e viabilizar o desenvolvimento das atividades;

- $\quad$ Estabelecimento de limitações do direito de voto e poder de veto a determinadas matérias visando a atribuir maior poder de decisão à parte com melhores condições de decidir a matéria;

- Possibilidade de acordo entre os sócios visando ao alinhamento prévio do procedimento decisório interno, controle da administração e venda futura do negócio, limitando os riscos de haver frequentes alterações contratuais para fazer frente às contingências do projeto;

Balanceamento entre o exercício do direito de "saída" dos sócios e a necessidade de execução das obrigações personalíssimas devidas;

Estabelecimento de regras para completar o contrato, em caso de surgimento de contingências.

\section{II.2.4. Natureza}

O contrato de venture capital enfatiza a organização da atividade a ser exercida $^{49}$ e tem natureza de um contrato plurilateral com comunhão de escopo.

\footnotetext{
${ }^{49}$ Para usar a terminologia de ASQUINI, enfatiza-se o "perfil funcional" da empresa. Sua proposta baseia-se em perfis que decompõem o conceito de empresa. Os perfis referem-se ao empresário (perfil subjetivo), atividade (perfil funcional), bens e estabelecimento empresarial (perfil objetivo) e organização de pessoas (perfil corporativo). (ASQUINI, Alberto. Os perfis da empresa. Tradução: COMPARATO, Fabio K. Revista de Direito Mercantil, Industrial, Econômico e Financeiro, Ano XXXV, n. 104, pp. 109-126, Out./Dez. 1996). Concordamos com LEÃES, que ensina que o tratamento legislativo aos distintos perfis da empresa não necessita ater-se a um esquema jurídico unitário, podendo enfatizar diferentes "perfis", conforme o caso. (LEÃES, Luiz Gastão P. B. A disciplina do direito de empresa no novo código civil. Revista de Direito Mercantil, Industrial, Econômico e Financeiro, Ano XLI, n. 128, Out.-Dez. 2002, p. 13).
} 
ASCARELLI define atividade como um conjunto de atos coordenados para alcançar a finalidade almejada. A atividade, independente dos atos singulares que a compõem, utiliza bens e requer capacidade dos agentes econômicos para desenvolvê-la, sendo o lucro a compensação pelos riscos da atividade ${ }^{50}$. Segundo COASE, a melhor forma de organização das atividades é a definição de um feixe de contratos que organize as trocas no mercado e reduza custos de transação ${ }^{51,52}$.

Para ASCARELLI, contrato plurilateral é aquele que se volta à constituição da organização, no qual todos os participantes têm direitos e obrigações específicos, mas não sinalagmáticos. O negócio não é bilateral, pois cada contratante assume obrigações para com todos os demais, havendo comunhão de finalidade. Nos contratos plurilaterais pode haver participação de duas ou mais partes. Há menor importância ao número de partes envolvidas e maior relevância à estrutura aberta do contrato, à noção de comunhão de escopo e à possibilidade de substituição de prestações ou partes sem que haja descontinuidade do negócio ${ }^{53}$.

$\mathrm{O}$ projeto de venture capital apresenta as características de um contrato plurilateral, no qual é necessária a organização do empreendimento, definição de direitos e obrigações dos sócios, distribuição dos riscos, forma de partilha dos resultados e controle das decisões críticas para o sucesso do projeto.

Venture capital também é negócio associativo, pois decorre da necessidade de colaboração, isto é, da reunião de pessoas em um centro de imputação autônomo, com objetivo de alcançar a finalidade comum ${ }^{54}$. É negócio organizado em torno da atividade

\footnotetext{
${ }^{50}$ ASCARELLI, Tullio, Corso di diritto commerciale - introduzione e teoria dell' impresa. $3^{\mathrm{a}}$ ed., Milano: Giuffrè, 1962, pp. 145-164; VERÇOSA, Haroldo M. D. Curso de direito comercial. São Paulo: Malheiros, 2004, vol. 1, pp. 52-55.

${ }^{51}$ COASE, Ronald H. "The nature of the firm". In The firm, the market, and the law. Chicago: University of Chicago Press, 1990, pp. 36-39; 41-42.

${ }^{52}$ LEẪES demonstra que o conceito apresentado por COASE não se opõe à noção jurídica de atividade. Indica que o legislador não está obrigado a tratar a empresa a partir de um esquema jurídico unitário, mas, ao contrário, deve dar tratamento distinto a cada um dos diversos perfis existentes. (LEÃES, Luiz Gastão P. B. A disciplina do direito de empresa no novo código civil. Revista de Direito Mercantil, Industrial, Econômico e Financeiro, Ano XLI, n. 128, Out.-Dez. 2002, p. 13).

${ }^{53}$ ASCARELLI, Tullio, Problemas das sociedades anônimas e direito comparado. $1^{\mathrm{a}}$ ed., São Paulo: Sarai va, 1945, pp. 273-332.

${ }^{54}$ SZTAJN, Rachel. Associações e sociedades. Revista de Direito Mercantil, Industrial, Econômico e Financeiro, Ano XLI, n. 128, Out./Dez. 2002, pp. 15-17.
} 
desempenhada, comum às partes e voltado a um resultado predeterminado.

Nestes negócios, os direitos das partes referem-se à realização da finalidade comum, isto é, são de mesmo tipo e natureza para todos os contratantes, variando apenas na proporção. Todos têm direitos de partilha dos resultados obtidos com o desenvolvimento do projeto.

As obrigações contratuais podem ser distintas para cada contratante. Nas relações com terceiros, empreendedor e investidor atuam em conjunto. A substituição da parte não desnatura ou invalida a natureza do negócio, e as obrigações individuais contratadas podem ser substituídas por outras sem afetar a validade do contrato, exceto se a prestação devida for personalíssima, isto é, essencial à continuidade do negócio, devendo ser prestada diretamente pelo sócio que a ela se obrigou. Em negócios de venture capital pode haver prestações essenciais de difícil substituição, por exemplo, atividades técnicas para desenvolvimento da ideia inovadora, a cargo do empreendedor.

Contratos plurilaterais são abertos, isto é, possibilitam a adesão de terceiros a qualquer tempo. A impossibilidade de execução da obrigação por uma das partes ou a resolução parcial do negócio referem-se apenas à parte em questão, não alcançando os demais participantes exceto se o objetivo do negócio não puder mais ser alcançado.

A impossibilidade relativa ou parcial do objeto não invalida, a priori, a conclusão do contrato. Ao contrário, o projeto de venture capital tem por objeto o desenvolvimento de ideia inovadora que pode vir a não se concretizar, levando ao abandono do empreendimento.

Contrato plurilateral é gênero que engloba duas espécies, associações e sociedades $^{55}$, dos quais são exemplos os contratos de sociedade, os de associação e os

\footnotetext{
${ }^{55}$ MAURO PENTEADO ensina que a doutrina italiana diverge sobre esse ponto. De um lado há a posição de ASCARELLI, que emprega o contrato associativo ora como sinônimo de contrato plurilateral, ora para designar contratos plurilaterais externos, nos quais as partes se relacionam com terceiros. De outro lado a concepção de MESSINEO, literal em relação ao artigo 1.420 do Código Civil italiano, que entende ser o contrato associativo gênero do qual o plurilateral seria espécie, este requerendo três ou mais partes. ASCARELLI expõe os argumentos a respeito de ser "possível participação de duas ou mais partes, possibilidade essa traduzida na integral subsistência do contrato plurilateral, como tal, ainda que, in concreto,
} 
de joint venture ${ }^{56}$.

Em todo contrato plurilateral, a prestação da parte reverte para todos os contratantes ${ }^{57}$. A resolução por inadimplemento depende da análise da essencialidade da prestação devida, pois a não realização da prestação inviabiliza a execução do contrato. ROPPO ensina que, quando não há essencialidade, os efeitos limitam-se à parte inadimplente. Ao contrário, se o inadimplemento referir-se a prestação essencial, isto é, personalíssima, considerada em relação às circunstâncias específicas do ne gócio, pode levar à sua dissolução ${ }^{58}$.

\section{II.2.5. Principais proble mas}

\section{II.2.5.1. Informação assimétrica}

A informação é assimétrica quando um agente econômico detém informação relevante para o negócio, desconhecida dos demais, e o primeiro tira proveito da vantagem, obtendo benefícios sem incorrer nos custos, que são suportados pelos outros $^{59}$. A assimetria implica em desbalanceamento entre as posições das partes relativamente aos fatores de risco do negócio.

Em negócios de venture capital, a informação assimétrica é fundamentada no

as partes sejam apenas duas. Essa característica - que diferencia claramente a espécie examinada dos contratos em geral - encontra sua razão de ser no escopo comum perseguido pelos contratantes, que acaba por se impor mesmo que duas sejam as partes". (itálicos do autor). (PENTEADO, Mauro R. Extinção de sociedades no Código Civil de 2002. In: Princípios do novo Código Civil Brasileiro e outros temas homenagem a Tullio Ascarelli. JUNQUEIRA DE AZEVEDO, Antonio; TORRES. Heleno T.; CARBONE, Paolo (org.). $2^{\text {a }}$ Ed., São Paulo: Quartier Latin, 2010, pp. 457-458).

${ }^{56}$ ROPPO, Vincenzo. Il contrato. Milano: Ed. Giuffrè, 2001, p. 129.

${ }^{57}$ ROPPO, Vincenzo, Op.cit., pp. 439-442.

${ }^{58}$ ROPPO, Vincenzo, Op.cit., pp. 870-871; 979-980.

${ }^{59}$ AKERLOF demonstrou que, em mercados nos quais o comprador se utiliza de estatísticas para avaliar a qualidade dos produtos, há incentivos para vendedores comercializarem mercadorias de baixa qualidade, pois o retorno obtido é o mesmo para todos. Em consequência, haveria redução da qualidade das mercadorias e do tamanho do mercado. Como os retornos sociais e privados são diferentes, seria necessário haver intervenção governamental para aumentar o bem-estar geral. O exemplo clássico apresentado é do mercado de carros usados de má qualidade ("lemons"), no qual o vendedor detém melhores informações sobre a qualidade do bem negociado e faz uso dessas informações para tirar vantagem na venda do veículo. Tal aspecto da incerteza é explorado pela teoria dos jogos no dilema do prisioneiro. (AKERLOF, George. The market for lemons: quality uncertainty and the market mechanism. Quarterly Journal of Economics. V. 84, n. 3, August, 1970, p. 488). 
conhecimento sobre a ideia inovadora, detido pelo empreendedor, que é revelado gradualmente ao investidor, mediante retribuição ${ }^{60}$.

Devido ao alto grau de incerteza que apresentam, contratos de venture capital são incompletos ${ }^{61}$, isto é, não preveem todas as contingências possíveis, devendo haver regras específicas para solução de conflitos. São contratos de execução continuada e longa duração ${ }^{62}$, nos quais é importante conhecer qual parte tem a preferência na tomada de decisões em caso de lacuna contratual. A viabilização do negócio é difícil se houver controle unicamente pelo empreendedor, porque o investidor não terá meios para monitorar o desempenho do projeto. Por isso, idealmente, o controle deve ser compartilhado, condição fundamental para viabilizar o aporte de recursos ${ }^{63}$.

A informação assimétrica favorece o empreendedor nas etapas em que o conhecimento sobre a ideia inovadora é relevante. Nestas etapas a informação detida pelo empreendedor é infungível e sua prestação é essencial para o sucesso do negócio, ao passo que as informações detidas pelo investidor são mais facilmente substituíveis.

O empreendedor possui, com exclusividade, conhecimento técnico para levar a cabo o desenvolvimento da ideia inovadora. Ele é capaz de especificar as atividades, identificar as dificuldades de execução e encontrar as possíveis soluções. Sua percepção sobre a possibilidade de sucesso do negócio pode ser viesada, uma vez que tem interesse pessoal no projeto e não contribui com recursos financeiros para sua execução, incorrendo em menores prejuízos em caso de fracasso do empreendimento.

\footnotetext{
${ }^{60} \mathrm{O}$ princípio da revelação determina qual a melhor solução que incentiva os agentes a indicarem suas preferências ao outro, simplificando escolhas. O princípio da revelação é válido em situações em que há moral hazard ou múltiplas etapas contendo decisões. O princípio permite tornar as estratégias legais mais atrativas do que as ilegais e maximiza a possibilidade de cumprimento voluntário de regras por parte dos agentes. (HURWICZ, Leonid. But who will guard the guardians? May 1998. Disponível em <http://www.econ.umn.edu/hurwicz>. Acesso em: 15.01.2008, pp. 3-4; 10-12).

${ }^{61}$ AZEVEDO, Paulo F. "Economia dos contratos". In ZYLBERSTAJN, Decio; SZTAJN, Rachel (coord.). Direito e Economia - Análise Econômica do Direito e das Organizações. São Paulo: Campus, 2005, pp. 102136; SZTAJN, Rachel; VERÇOSA, Haroldo M. D. A incompletude do contrato de sociedade. Revista de Direito Mercantil, Industrial, Econômico e Financeiro, Ano XLII, n. 131, Jul./Set. 2003, pp. 7-13.

${ }^{62}$ Ver, a respeito de contratos de longa duração e execução continuada: SZTAJN, Rachel. Direito e Economia dos contratos. Os conceitos fundamentais. In: VERÇOSA, Haroldo M. D. Curso de direito comercial. São Paulo: Malheiros, Vol. 4, Tomo I, 2011, p. 83.

${ }^{63}$ BOLTON, Patrick; DEWATRIPONT, Mathias. Contract theory. MIT Press, 2005, pp. 36-37; 526-534.
} 
O investidor não conhece as atividades técnicas para desenvolvimento da ideia inovadora e, normalmente, não se envolve na condução das atividades, porque não detém o conhecimento necessário. Por isso, acaba por atribuir maior incerteza ao ne gócio e taxa de desconto ${ }^{64}$ mais elevada sobre o retorno esperado.

Inicialmente, o poder de decisão sobre a administração de atividades operacionais do negócio é atribuído ao empreendedor, e transferido ao investidor somente se o negócio apresentar desempenho insatisfatório. O objetivo da alocação inicial de direitos é permitir ao empreendedor executar o contrato, revelando ao investidor a informação necessária. Se o negócio apresentar desempenho insatisfatório, o investidor passa a interferir diretamente na administração, mas, se o desempenho for satisfatório, o investidor apenas monitora as atividades realizadas e os resultados alcançados.

Como há distintos enquadramentos ${ }^{65}$ sobre a expectativa de risco e retorno, o investidor costuma deter o poder de decidir se aportará, ou não, recursos a cada etapa do projeto. Em contrapartida, o empreendedor deve ceder ao investidor participação no negócio que seja suficiente para compensar os riscos. Como a informação assimétrica favorece o empreendedor nessas etapas, o investidor manterá o controle sobre as decisões críticas, usando esse poder para compensar a desvantagem informacional. Em especial, o investidor mantém o poder de interromper o empreendimento, minimizando riscos e evitando perdas futuras (stop loss), quando entender que o negócio é arriscado e não há informação suficiente para reduzir a incerteza.

O investidor pode preferir deter participação minoritária no negócio, porque esta condição lhe permite mi ni mi zar riscos, porém implica em menor poder de decisão. Para evitar essa redução de poder, mantém o poder de veto sobre determinadas matérias

\footnotetext{
${ }^{64}$ A taxa de desconto serve para trazer a valor presente um determinado valor futuro, isto é, representa o fluxo financeiro do resultado, trazido a valor presente líquido. A taxa de retorno deve ser ajustada ao perfil de risco, pois este determina diferentes taxas para uma mesma situação fática. $\mathrm{O}$ investidor avesso a riscos aplica uma taxa maior que aquele com propensão a tomar risco.

${ }^{65}$ A noção de enquadramento indica que as partes avaliam escolhas a partir de um ponto de vista que serve como referência cognitiva para a avaliação da qualidade das decisões. (TVERSKY, Amos; KAHNEMANN, Daniel. Prospect Theory: An Analysis of Decision Under Risk. Econometrica, Vol. 47, n. 2, pp. 263-292, Mar. 1979; Rational Choice and the Framing of Decisions. Journal of Business, Vol. 59, n. 4, Part. 2: The Behavioral Foundations of Economic Theory, pp. S251-278, Oct. 1982.
} 
consideradas críticas para o sucesso do empreendimento.

Como a assimetria é maior nas etapas iniciais do projeto e o empreendedor sempre pode se retirar do negócio levando consigo a informação, a renegociação periódica das condições contratuais pode ser necessária para ajustar a relação riscoretorno das partes.

Ao final do projeto, na etapa de desinvestimento, a assimetria informacional favorece o investidor, que detém conhecimento exclusivo a respeito da estruturação da operação de venda do negócio e dos potenciais interessados na oferta.

Um dos principais riscos do projeto de venture capital é não haver, no contrato, incentivos suficientes para revelação de informação às partes, afetando o regular desenvolvimento do projeto.

\section{II.2.5.2. Conflitos de agente-principal}

Negócios de venture capital estão sujeitos a conflitos de agente-principal, nos quais o contratante ("principal") contrata terceiro ("agente") para a realização de atividades, delegando-lhe a tomada de decisões.

O conflito decorre da existência de informação assimétrica, referindo-se aos custos incorridos quando os interesses do contratado não estão alinhados aos do contratante. Os custos do desalinhamento são suportados pelo contratante e decorrem da falta de cuidado ou desídia do agente na execução das atividades contratadas.

Em negócios de venture capital o conflito manifesta-se, principalmente, entre os sócios e os administradores contratados para conduzir o projeto, como, por exemplo, os diretores ou conselheiros de administração nomeados ${ }^{66}$. Nesta situação, um dos riscos

${ }^{66}$ Principais conflitos apresentados por: BLACK, Bernard S.; CARVALHO, Antonio Gledson de; SAMPAIO, Joelson O. The Evolution of Corporate Governance in Brazil, Northwestern University School of Law, Law and Economics Research Paper No. 12-22 (draft November 2012), Disponível em: <http://ssrn.com/abstract=2181039>. Acesso em: 01.02.2013, pp. 20-21; CUMMING, Douglas; JOHAN, Sofia. Information asymmetries, agency costs and venture capital exit outcomes. Venture Capital, an 
do projeto é a insuficiência de incentivos para revelação de informação e fiscalização da conduta adotada pelos administradores, com efeitos negativos sobre a condução das atividades.

Há também risco para o negócio quando a fiscalização excessiva inviabiliza o desenvolvimento do projeto pelos administradores, pois, muitas vezes, a incerteza do projeto exige haver discricionariedade na conduta da administração que pode ser confundida com falta de cuidado ou desídia, levando a entendimento equivocado sobre a existência do conflito de agente-principal.

\section{II.2.5.3. Seleção adversa}

Antes da contratação definitiva do negócio, a informação assimétrica a respeito da qualidade do empreendimento pode levar a problemas de seleção adversa ${ }^{67}$, isto é, erro da decisão de investir no projeto.

O principal erro de decisão de contratação do negócio é incorrido pelo investidor, porque, nesta etapa, a informação assimétrica favorece o empreendedor. $\mathrm{O}$ erro pode tomar duas formas básicas: 1) erro do tipo I, no qual o investidor aporta recursos em negócio "inviável”, ou seja, projeto com expectativa de retorno inferior ao esperado; 2) erro do tipo II, no qual o investidor deixa de investir em projeto "viável",

International Journal of Entrepreneurial Finance (2008). Draft (December 2007). Disponível em: <http://papers.ssrn.com/paper.taf?abstract_id=1265947>. Acesso em: 11.03.2011; FRIED, Jesse M.; GANOR, Mira. Agency costs of venture capitalist control in startups. New York University Law Review, Vol. 81, pp. 101-156. Disponível em: <http://ssrn.com/abstract=784610>. Acesso em: 06.10.2012; IHA, Márcio Y. Problemas de agência no relacionamento fundo de capital de risco - empreendedor no Brasil: um estudo de caso. Dissertação de Mestrado. São Paulo: Fundação Getúlio Vargas, 2003; OFFA, Luiz F. W. Contratos financeiros entre empreendedores e gestores de fundos de private equity e venture capital: teoria e realidade no caso brasileiro. Dissertação de Mestrado. São Paulo: Fundação Getúlio Vargas, 2005.

${ }^{67}$ A seleção adversa ocorre antes da celebração do contrato, quando a parte que detém informação assimétrica não a revela com vistas a obter benefícios, impondo custos à outra parte. A parte lesada não consegue obter a informação e, por isso, toma decisão incorreta. Por exemplo, a oferta de seguros de saúde tende a atrair clientes com maior risco de apresentar doenças porque a seguradora tem dificuldade em distinguir o "bom cliente" (com baixo risco de doenças) do "mau cliente" (com alto risco de doenças e, portanto, maior probabilidade de utilizar-se do seguro). Nesse caso, espera-se que o cliente oportunista com informação privilegiada sobre sua própria saúde irá esconder a informação da seguradora, visando a reduzir o custo de participação no plano de saúde. A diferença (entre o custo real e o custo efe tivamente pago pelo cliente) prejudicará a parte que não detém a informação relevante, no caso, a seguradora. (AKERLOF, George. The market for lemons: quality uncertainty and the market mechanism. Quarterly Journal of Economics. V. 84, n. 3, pp. 488-500, August, 1970). 
isto é, com retorno igual ou superior ao esperado ${ }^{68}$.

Do ponto de vista do investidor, o erro do tipo I implica em alocação ineficiente de recursos e o erro do tipo II resul ta em perda de uma oportunidade de investimento. No momento em que se toma a decisão de investimento não há certeza se o negócio será viável ou não, havendo mera expectativa de retorno. No caso do erro do tipo I, a inviabilidade do negócio será experimentada diretamente pelo investidor quando o projeto fracassar e ele perder os recursos aplicados. No caso do erro do tipo II, a viabilidade do investimento manifesta-se somente se o negócio for oferecido a outro investidor e, ao final, o projeto se mostrar bem sucedido, caso em que o primeiro investidor - que recusou a oferta - terá perdido uma oportunidade de investimento. Nesta situação, deve ser possível ao investidor que recusou o projeto observar o resultado obtido pelo segundo investidor, para compará-lo com sua expectativa original de retorno sobre o investimento.

Os dois tipos de erros podem ser mais bem explicados com um exemplo. O erro do tipo I é o "falso positivo", isto é, quando o médico supõe, erroneamente, ter descoberto a cura do câncer e passa a prescrever o medicamento, percebendo, posteriormente, que o remédio era inócuo, porque os pacientes começam a morrer de câncer. O erro do tipo II é o "falso negativo", ou seja, o médico descobriu a cura do câncer, mas não percebeu o feito, deixando de prescrever o medicamento aos pacientes, que passam a morrer de câncer. Qual seria, então, o erro mais grave: prescrever medicamento inócuo ou não administrar o remédio salvador?

A tipologia do erro tem sido aplicada ao estudo do Direito. Ao tratar do conflito de interesses relativo à conduta dos administradores de sociedades por ações, LUCA ENRIQUES indica que o "falso negativo" é o abuso cometido pelo administrador que permanece impunível porque o caso não foi submetido ao Poder Judiciário ou foi

\footnotetext{
${ }^{68}$ Ao formular hipóteses, um dos objetivos do cientista é verificar se uma ideia nova é melhor ou pior que uma ideia básica ("hipótese normal", ou "hipótese nula") que reflete o resultado esperado. Os erros de verificação podem ser de dois tipos: rejeitar hipótese verdadeira ou aceitar hipótese falsa. O teste de hipóteses é procedimento usado para tal verificação, no qual são formuladas proposições e avaliadas as respostas. Há duas possibilidades de haver decisões incorretas. O erro do tipo I ocorre quando a hipótese verdadeira é rejeitada. O erro do tipo II ocorre quando a hipótese falsa não é rejeitada. (SANDRONI, Paulo. Dicionário de Economia. $3^{a}$ ed., São Paulo: Best Seller, 1994, p. 119; HOEL, Paul G. Estatística elementar. São Paulo: Atlas, 1977, pp. 201-202).
} 
impossível provar o abuso. O "falso positivo" é o conflito potencial de interesses, no qual o administrador agiu em conformidade com o interesse da companhia, mas o juiz entendeu ter provado sua má conduta e o prejuízo causado à sociedade. Qual o erro mais grave: deixar de punir o administrador que age em conflito de interesses ou punir indevidamente aquele que age no interesse da sociedade ${ }^{69}$

A seleção adversa manifesta-se antes da contratação do negócio. Trata-se de um erro de decisão, porque a informação relevante não é conhecida pelo investidor no momento da tomada de decisão de contratação. Por isso, para limitar o risco e reduzir a possibilidade de erro, investidores de venture capital atuam em indústrias e mercados sobre os quais têm maior conhecimento e experiência.

Outra forma de redução de problemas de seleção adversa é o estabelecimento de um procedimento de investigação preliminar à contratação para verificar as condições do negócio e a capacidade do empreendedor em executar o projeto, conhecido na ciência econômica como screening e na ciência jurídica como due diligence.

O screening é um mecanismo ${ }^{70}$ de investigação sobre as características do negócio. Visa a obter informações para a tomada de decisão e garantir a alocação eficiente de recursos, segundo critérios previamente estabelecidos ${ }^{71}$. Serve para

${ }^{69}$ ENRIQUES, Luca. Il conflitto d'interessi nella gestioni delle società per azioni: spunti teorici e profili comparatistici in vista della riforma del diritto societario. Rivista delle Società, Ano 45 / 2000, Mai./Ago. 2000 , fascículo $3^{\circ}-4^{\circ}$, p. 512 .

${ }^{70}$ Mecanismo é estrutura que fornece elementos para definir soluções eficientes a partir das preferências e crenças dos agentes. O mecanismo ideal deve buscar o cumprimento dos contratos pelos próprios agentes, simplificando a supervisão e reduzindo os custos de transação (HURWICZ, Leonid. But who will guard the guardians? May 1998. Disponível em 〈http://www.econ.umn.edu/hurwicz〉. Acesso em: 15.01.2008). De acordo com FIANI, mecanismo é sistema de captação de mensagens no qual os participantes enviam informação à "central de mensagens" que processa um conjunto de regras predefinidas e conhecidas dos jogadores, atribuindo resultados aos participantes. Cada regra pode levar a diversos resultados, ou equilíbrios, alcançados quando todos os agentes emitem mensagens que representam preferências. Equilíbrio é o conjunto de mensagens que maximiza os ganhos de cada participante, dadas as mensagens enviadas pelos demais. Mecanismos não servem somente para analisar a melhor estratégia que o jogador deve adotar, mas também para definir como a interação deve ocorrer, uma vez que permitem que os jogadores participem da definição das regras do jogo. (FIANI, Ronaldo. Teoria dos jogos. $2^{\mathrm{a}}$ ed., São Paulo: Campus, 2006, pp. 317; $321)$.

${ }^{71}$ Trata-se de eficiência alocativa, isto é, busca do melhor resultado ao menor custo possível. A eficiência pode ser baseada nos critérios de Pareto ou Kaldor-Hicks, mas, quando há informação privada detida pelos agentes, é preferível usar o segundo critério. MERCURO e MEDEMA entendem que a decisão não está no ponto ótimo de Pareto se ainda podem ocorrer mudanças que permitam ao agente melhorar sua situação sem prejudicar os demais. A noção de Kaldor-Hicks baseia-se no princípio da compensação potencial, isto é, o 
identificar e avaliar propostas de negócio, identificando as oportunidades de interesse do investidor e minimizando a ocorrência de erros de avaliação.

Como não há relacionamento prévio ou reputação estabelecida entre os contratantes de venture capital, há necessidade de estabelecimento de contratos sofisticados para limitação dos riscos da etapa de due diligence. Não há consenso entre os estudiosos a respeito da maior ou menor necessidade de sofisticação dos contratos e dos impactos na redução de assimetrias informacionais ${ }^{72}$.

A due diligence em negócios de venture capital pode não ser conclusiva por que a ideia inovadora e a forma de desenvolvê-la são desconhecidas do mercado, não havendo referências confiáveis sobre a qualidade do projeto. Por isso, muitas vezes o investidor deixa de realizar a atividade, evitando incorrer nos custos elevados do procedimento de investigação. Em substituição, o investidor submete o projeto a avaliação técnica por equipe de especialistas, analisa a "qualidade" dos empreendedores, isto é, seu perfil e habilidades demonstradas, e utiliza algum método de avaliação, normalmente um sistema próprio de pontuação (scorecard) ou uma avaliação por múltiplos ${ }^{73}$ que lhe permita estimar o valor que estará disposto a investir.

O risco de seleção adversa do investimento afeta a disposição das partes em contratar o negócio, devendo ser limitado pela negociação e mecanismos eficientes para revelação de informação.

\section{II.2.5.4. Moral hazard}

Moral hazard ${ }^{74}$ é definido como a alteração de comportamento do contratante,

\footnotetext{
beneficiado pela mudança pode compensar o prejudicado e permanecer melhor do que estava, ou então o prejudicado não pode compensar o beneficiado para voltar à situação anterior sem piorar sua situação. A compensação não precisa ocorrer de fato, basta que seja potencial. (MERCURO, Nicholas; MEDEMA, Steven G. Economics and the law. Princeton: Princeton University Press, 1997, pp. 25-31; 37-50).

72 BOTAZZI, Laura; DA RIN, Marco; HELLMANN, Thomas. The importance of trust for investment: evidence from venture capital. September, 2010. Disponível em: 〈http://www.jstor.org/stable/997934>. Acesso em: 27.01.2012.

${ }^{73}$ Anexo VI.3.

${ }^{74}$ Moral hazard ocorre quando o indivíduo pode influenciar o grau de risco, alterando seu comportamento após a contratação do negócio com a outra parte. (PINDYCK, Robert S.; RUBINFELD, Daniel L. Microeconomia. São Paulo: Pearson - Prentice Hall, 6a . Ed., 2006, pp. 539).
} 
depois de concluído o contrato, visando a alcançar benefícios sem incorrer em custos. A parte que não revelou a informação modifica o comportamento após a celebração do negócio, impondo custos adicionais à outra parte.

Em projetos de venture capital há possibilidade de haver duplo moral hazard, isto é, adoção de comportamentos oportunistas pelo empreendedor e pelo investidor.

O moral hazard pressupõe que não haverá condições de monitorar as atividades desempenhadas pelo agente oportunista, ou que será muito oneroso fazê-lo. Ao contrário da seleção adversa, o moral hazard manifesta-se depois da celebração do contrato e, para ser evitado, requer alinhamento de incentivos e fiscalização da conduta adotada pelas partes.

Uma forma de reduzir o moral hazard é por intermédio da sinalização ${ }^{75}$, definida como a atitude voluntária de fornecer informação relevante à outra parte, visando a reduzir a desconfiança recíproca.

Em negócios de venture capital são exemplos de sinalização: 1) assunção, pelo contratante, de parcela maior dos riscos, como forma de indicar a viabilidade do negócio; 2) oferecimento de garantias à execução, para demonstrar a qualidade do empreendimento; 3) assunção unilateral de custos incorridos para fornecer informação relevante à outra parte, demonstrando o interesse em contratar; 4) tornar a remuneração das partes variável, calculada em função do desempenho alcançado pelo negócio; 5) investir recursos próprios no projeto ${ }^{76}$;6) oferecer ao investidor prioridade na

\footnotetext{
${ }^{75}$ A teoria da sinalização e informação assimétrica indica que os agentes detêm informação privada sobre o negócio, não conhecida da outra parte. Por isso, a parte vendedora pode exagerar a qualidade do projeto, pois a parte compradora não conhece a informação. Como a parte enganada pode supor que a outra utilizaria tal subterfúgio se dele dispusesse, ela pode observar as atitudes e tentar inferir a existência de assimetrias. A sinalização é mecanismo segundo o qual a parte bem informada apresenta informações que objetivamente diminuam tal percepção na outra parte. Por exemplo, a disposição do empreendedor de investir capital próprio no projeto sinaliza sua confiança na qualidade do empreendimento e em sua capacidade de execução. Por isso, a teoria da sinalização e informação assimétrica indica haver dependência entre o valor do negócio e a decisão de financiá-lo com capital próprio ou alheio. Ver: FURTADO, Claudio V. Emissão de ações e valor de mercado da empresa: um estudo de ofertas primárias de ações negociadas em bolsas de valores no Brasil. Tese de Doutorado, São Paulo: EAESP/FGV, 1997, pp. 28-30; 38-39.

${ }^{76}$ De acordo com GINTIS, a alocação de capital próprio ao negócio é forma eficiente de sinalização. Serve para distinguir bons projetos dos inviáveis. Como o retorno sobre o capital interessa tanto a investidores quanto a empreendedores, a disposição de investir capital próprio sinaliza a qualidade do projeto ao outro.
} 
devolução dos recursos investidos, em caso de insucesso do empreendimento.

A sinalização é realizada pelo contratante quando reconhece a importância de fornecer informação à outra parte para viabilizar a conclusão do negócio. Além de demonstrar as intenções do agente, a sinalização deve ser crível, isto é, fornecer meios eficientes para que a outra parte possa se certificar da veracidade do conteúdo e da relevância da informação. A sinalização voluntária denota a disposição em agir com boa fé e diligência na contratação do ne gócio e execução das atividades.

Em venture capital, o dever de informar e a boa fé na contratação e execução do negócio são essenciais, pois o equilíbrio contratual depende da organização da colaboração, que, por sua vez, depende da informação revelada pelas partes. Os contratos devem prever incentivos para cooperação, regras para revelação de informação, sanções críveis para o caso de inadimplemento das obrigações, alocação de riscos e benefícios da execução do projeto e regras para completar o contrato durante sua execução ${ }^{77}$.

Tanto a sinalização quanto o screening podem ser usados pelo empreendedor ou pelo investidor, porém, normalmente, o empreendedor tem menor disponibilidade de recursos para fazer frente aos custos correspondentes. Por isso tem incentivos para tentar obter do investidor recursos em quantidade maior que a necessária para executar o projeto, criando uma "reserva para contingências" que reforçará sua posição em negociações futuras. O investidor, consciente da estratégia adotada pelo empreendedor, terá que inferir a real necessidade de recursos em cada etapa, fornecendo-os de maneira

\footnotetext{
Diversamente, a parte que não detém a informação pode inferir que, quando o negócio é bom, a parte que propõe o negócio jamais dividiria com a outra os benefícios, pois tenderia a preferir se apropriar de todo o lucro. Quando a parte opta por buscar investidores externos e não investe recursos próprios, sinaliza que não está disposta a compartilhar os riscos de insucesso, indicando a má qualidade do negócio. O investidor observa a proporção do investimento realizado pelo empreendedor, utilizando a informação para ajustar sua participação. Dependendo da probabilidade estimada de sucesso do negócio, o investidor pode calcular o real risco tomado pelo empreendedor e medir sua própria disposição para investir recursos. (GINTIS, Herbert. Game theory evolving - A problem-centered introduction to modeling strategic interaction. Princeton: Princeton University Press, 2000, pp. 329-331; MYERS, Stewart; MAJLUF, Nicholas. Corporate financing and investment decisions when firms have information the investors do not have. National Bureau of Economic Research. Working Paper 1396 (July 1984). Disponível em: < http://www.nber.org/papers>. Acesso em: 27.01.2012).

${ }^{77} \mathrm{Na}$ mesma linha: SZTAJN, Rachel. Direito e Economia dos contratos. Os conceitos fundamentais. In: VERÇOSA, Haroldo M. D. Curso de direito comercial. São Paulo: Malheiros, Vol. 4, 2011, pp. 86-87.
} 
gradual e condicionada à qualidade do desenvolvimento das atividades e aos resultados parciais alcançados.

Os riscos de moral hazard em negócios de venture capital são frequentes e de difícil percepção pelas partes, devendo o contrato prever regras para sua limitação.

\section{II.2.5.5. Ameaças críveis}

Ameaça é promessa de adotar determinada atitude que modifica os resultados esperados pelos agentes econômicos. A ameaça é crível quando há fundamentos para entender que a promessa será cumprida por aquele que a faz. A ameaça crível deve poder ser observada pelos demais agentes e deve ser irreversível, isto é, aquele que faz a ameaça não pode ter incentivos para desistir de executá-la ${ }^{78}$.

Em negócios de venture capital, as principais ameaças estão relacionadas ao abandono prematuro do projeto pelo empreendedor, à interrupção do projeto cujas perdas superarem as expectativas do investidor (estratégia de stop loss) e à redução do esforço pessoal depois que a outra parte cumpriu com suas obrigações (estratégia de hold-up).

O empreendedor pode fazer ameaça de abandonar prematuramente o negócio e oferecer o desenvolvimento da ideia a outros interessados, causando prejuízos ao investidor. A ameaça será crível quando houver prestações personalíssimas a realizar pelo empreendedor, caso em que o inadimplemento da obrigação inviabiliza o negócio.

Negócios de venture capital dependem da permanência do empreendedor e sua substituição pode inviabilizar o projeto, especialmente nas etapas iniciais, em que a aplicação do know-how para desenvolvimento da ideia é obrigação personalíssima ${ }^{79,80}$.

\footnotetext{
${ }^{78}$ FIANI, Ronaldo. Teoria dos jogos. $2^{\mathrm{a}}$ ed., São Paulo: Campus, 2006, pp. 234-235; 242; 269-270.

${ }^{79}$ Há teorias econômicas que contestam a possibilidade de limitação à resolução contratual, afirmando que o empreendedor não pode ser obrigado a permanecer indefinidamente vinculado a contrato que não seja de seu interesse, ainda que, para desvincular-se, tenha que oferecer compensação ao investidor. Os argumentos sugerem que o empreendedor não pode obrigar-se a permanecer por tempo indeterminado no negócio porque o "capital humano" seria inalienável e seu controle não seria transferível a terceiros por prazo indeterminado. Entretanto, tal afirmação deve ser temperada pela necessidade de haver cumprimento das obrigações
} 
A substituição do investidor é mais fácil de ocorrer, por que o fornecimento de recursos pode ser realizado por outro fornecedor. Aliás, é situação frequente que investidores cedam sua participação no negócio a terceiros durante o desenvolvimento do projeto, quando não lhes interessar permanecer, sem que a decisão afete a continuidade das atividades.

A ameaça de abandono do projeto pode resultar na resolução do contrato ou implicar em custos adicionais, decorrentes da negociação entre o sócio descontente e os remanescentes. Por isso, a parte que não deseja cumprir sua obrigação, quando esta for essencial ao negócio, pode adotar estratégia de inadimplemento eficiente para forçar a renegociação do contrato e tentar extrair vantagens da outra parte.

O inadimplemento eficiente é situação na qual a parte avalia custos e benefícios de cumprir, ou não, as obrigações contratuais. Quando a parte acredita que a obrigação é desproporcional ou excessiva, pode submeter ao Judiciário pedido de revisão das prestações ou requerer a resolução do contrato. Como o negócio depende da execução da prestação pelo inadimplente, pode haver interesse da outra parte em renegociar o contrato visando a garantir a continuidade do projeto. Se houver interesse na renegociação, isto é, se as perdas decorrentes do inadimplemento forem maiores que o valor obtido com a renegociação, o inadimplente pode obter concessões em troca de

contratuais assumidas pelas partes, especialmente em empreendimentos dotados de alto grau de incerteza, nos quais a cooperação entre os agentes é elemento essencial para o sucesso do projeto. (HART, Oliver; MOORE, John. A theory of debt based on the inalienability of human capital. The Quarterly Journal of Economics, Vol. 109, No. 4 (Nov., 1994), pp. 841-879. Disponível em: <http://qje.oxfordjournals.org/content/109/4/841>. Acesso em: 27.01.2012; HELLMANN, Thomas. The allocation of controls rights in venture capital contracts, RAND Journal of Economics, vol. 29, N. 1 (Spring 1998), pp. 57-76. Disponível em: 〈http://www.jstor.org/stable/2555816>. Acesso em: 27.01.2012).

${ }^{80}$ DEWATRIPONT e TIROLE entendem que o equilíbrio contratual encontra-se entre dois extremos do fluxo de pagamentos gerado pelo negócio. O negócio pode ser desenhado para prever fluxo de pagamento mais lento ou mais rápido aos investidores. $\mathrm{O}$ contrato de pagamento lento apresenta empréstimo inicial maior e fluxo mais lento de pagamentos, ao passo que o contrato de pagamento rápido configura-se com empréstimo inicial menor e fluxo mais rápido de pagamentos. $\mathrm{O}$ financiamento de curto prazo mantém o endividamento em níveis mais baixos e antecipa a devolução dos recursos emprestados, mas implica em manter mais direitos nas mãos do investidor, o que pode levar à liquidação prematura do negócio. Por outro lado, o financiamento de longo prazo mantém mais direitos nas mãos do empreendedor e mais riscos suportados pelo investidor. Em termos de incentivos, o financiamento de longo prazo limita a possibilidade de controle do negócio pelo investidor, favorecendo o empreendedor. Como o pagamento lento é feito a valores menores em cada período, aumenta o valor presente do negócio. E, quanto maior o valor do negócio, maior a possibilidade de obter novo financiamento para a etapa seguinte. (DEWATRIPONT, Mathias; TIROLE, Jean. A theory of debt and equity: diversity of securities and manager-shareholder congruence. Quarterly Journal of Economics, Vol. 109, n. 4 (Nov., 1994). Disponível em: <http://www.jstor.org/stable/2118355>. Acesso em: 27.01.2012, pp. 1041-1043). 
acordo para encerramento do litígio. Uma vez que o reconhecimento da essencialidade da prestação devida não é facilmente observável pelo juiz ou árbitro, as partes terão interesse em renegociar diretamente o contrato, sem o envolvimento de terceiros, porque esta atitude minimiza os custos de transação e os riscos de submeter-se aos efeitos de uma decisão inadequada.

Há também ameaça crível decorrente da possibilidade de usufruir dos benefícios privados do controle, definidos como o uso de recursos do projeto em proveito pessoal daquele que administra o negócio, normalmente o empreendedor. Os benefícios podem ser pecuniários, ou não, como, por exemplo, o controle sobre os ativos alocados ao projeto, o uso de bens da sociedade em benefício próprio, o status de sua posição, que define sua empregabilidade futura, etc.

Em negócios de venture capital, não há relacionamento prévio entre as partes, o empreendimento é de longa duração e alto risco, o retorno econômico ocorre nas etapas finais do projeto e monitorar o desempenho do administrador é atividade complexa. Por isso, o administrador sempre tem incentivos para usufruir dos benefícios privados do controle, porque lhe traz algum retorno imediato, ainda que em prejuízo dos demais sócios e da sociedade.

Se abandonar o projeto, o empreendedor perde o controle sobre o negócio. Como o projeto ainda não está terminado e a continuidade depende de sua permanência para realização das atividades pendentes, as partes podem ter interesse em renegociar o contrato. Mesmo assim, a negociação pode não levar a resultados eficientes e o investidor pode preferir liquidar o negócio ainda que o valor da renegociação exceda o de liquidação, para não se sujeitar a ameaças praticadas pelo empreendedor ${ }^{81}$.

A renegociação do contrato pode ocorrer em todas as etapas do projeto, pois a avaliação de desempenho do negócio e dos administradores pode levar a ajustes contratuais e redistribuição de riscos e benefícios durante a execução. O financiamento

${ }^{81}$ HART, Oliver; MOORE, John. A theory of debt based on the inalienability of human capital. The Quarterly Journal of Economics, Vol. 109, No. 4 (Nov., 1994). Disponível em: <http://qje.oxfordjournals.org/content/109/4/841>. Acesso em: 27.01.2012, pp. 842; 849-850. 
gradual em cada etapa do projeto é a principal estratégia para limitar as perdas. O investidor condiciona a liberação de novos recursos a medidas observáveis de desempenho negociadas previamente, como por exemplo, expectativas de EBITDA $^{82}$, valor de mercado do projeto ou concessão de patentes após o decurso de determinado tempo. A ameaça de não renovação pelo investidor é crível e visa a manter o empreendedor interessado no desenvolvimento do projeto em cada etapa, mas pode estar sujeita aos conflitos já indicados ${ }^{83,84}$

Há também a ameaça de hold-up, que pode ser adotada pelo empreendedor ou pelo investidor. Hold-up significa "retenção" ou "engarrafamento", e é definido como a estratégia de protelar ou reduzir o esforço dedicado ao cumprimento da prestação contratual depois que a obrigação da outra parte é cumprida.

O empreendedor pode reduzir o esforço empregado no desenvolvimento das atividades do projeto após a transferência de recursos pelo investidor, estratégia conhecida como shirking, que significa "esquivar-se".

O investidor também pode adotar estratégia de hold-up se silenciar e não oferecer novas oportunidades de negócio ao empreendedor, quando relacionadas ao projeto já contratado. Outra forma é adiar a venda de negócio concluído visando a extrair maiores benefícios pessoais da operação.

Há diversas maneiras de limitar parcialmente as ameaças: 1) manter em poder do investidor a decisão de fornecer somente os recursos necessários para executar a

\footnotetext{
${ }^{82}$ EBITDA é a sigla inglesa que significa: resultado antes dos juros, impostos, depreciações e amortizações.

${ }^{83}$ HELLMANN, Thomas. The allocation of controls rights in venture capital contracts, RAND Journal of Economics, vol. 29, N. 1 (Spring 1998), pp. 57-76. Disponível em: <http://www.jstor.org/stable/2555816>. Acesso em: 27.01.2012.

${ }^{84}$ BOLTON e SCHARFSTEIN indicam duas razões para a impossibilidade de renegociação entre o empreendedor e o investidor. Primeiro, pode ser do interesse do investidor não renegociar para extrair maiores benefícios nas primeiras etapas do projeto. Como os custos de negociação são significativos, pode ser interessante ao empreendedor diluir a captação de recursos entre múltiplos investidores, pois, desta forma, cada investidor fornece parcela menor de recursos ao negócio, reduzindo o interesse individual pela renegociação do contrato. Segundo, a informação sobre rentabilidade do negócio é, em geral, assimétrica, e o investidor desconhece o real valor do projeto, mas sabe, objetivamente, que a simples oferta de renegociação sinaliza que o valor declarado pelo empreendedor não corresponde à realidade. (BOLTON, Patrick; SCHARFSTEIN, David S. The theory of predation based on agency problems in financial contracting. The American Economic Review, vol. 80, n. 1 (Mar., 1990). Disponível em: <http://www.jstor.org/stable/2006736>. Acesso em: 27.01.2012, pp. 102-104).
} 
etapa em andamento, decidindo pela continuidade ou interrupção do negócio; 2) estipular remuneração variável às partes, proporcional ao resultado de cada etapa do projeto, para mantê-las interessadas no bom andamento do negócio; 3) estabelecer cláusulas de exclusividade e garantia de permanência ${ }^{85}$ do empreendedor e do investidor, de forma a tornar mais oneroso o abandono do projeto; 4) estipular a proibição de o investidor financiar negócios concorrentes ao mantido com o empreendedor $^{86}$, evitando a revelação indesejada de informação a terceiros; 5) limitar as hipóteses de despedida ou retirada de sócios em cada etapa do projeto, condição que nem sempre é permitida pela legislação.

Por fim, a alocação dos prejuízos exclusivamente à parte com melhores condições econômicas de suportá-los (estratégia de deep pocket ${ }^{87}$ ) nem sempre é adequada para equilibrar as relações contratuais nesse tipo de negócio, porque o investidor teria que arcar com a maior parcela dos custos, ainda que os prejuízos tenham sido causados exclusivamente pelo empreendedor.

\section{II.2.5.6. Jogo finito}

O projeto de venture capital é jogo repetitivo de informação incompleta ${ }^{88}$, porém finito, encerrando-se com a "saída" do investidor (etapa de desinvestimento),

\footnotetext{
${ }^{85}$ Cláusulas de exclusividade servem para manter o empreendedor participando do negócio, especialmente naqueles que dependem de seu conhecimento e habilidades. As cláusulas internalizam o custo de saída antecipada do empreendedor e podem ser de duas formas: cláusulas restritivas de participação em projetos concorrentes e cláusulas de exercício gradual de direitos sobre opções. As primeiras estabelecem período no qual este não poderá atuar em empreendimento concorrente, sujeitando-o a multas contratuais e responsabilização por perdas e danos em caso de descumprimento. As cláusulas de exercício gradual dos direitos sobre opções determinam que o exercício de opções de compra de ações esteja condicionado à permanência do empreendedor no negócio até o final de cada etapa do projeto. Caso haja abandono prematuro antes do prazo estabelecido, a parte perde, proporcionalmente, os direitos de exercício de opções não vencidas. (KAPLAN, Ste ven N.; STRÖMBERG, Per. Financial contracting theory meets the real world: an empirical analysis of venture capital contracts. The Review of Economic Studies, Vol. 70, No. 2 (Apr., 2003). Disponível em: <www.jstor.org/stable/3648635>. Acesso em: 07.09.2010, p. 292).

${ }^{86}$ Cláusulas proibitivas de investimento em negócios concorrentes são da natureza do negócio de venture capital. Dificilmente, o investidor conseguirá coordenar dois projetos concorrentes sem aumentar o risco de compartilhamento indevido de informação, podendo ser demandado em juízo pelo empreendedor lesado pela revelação inadvertida. $\mathrm{O}$ empreendedor, que detém informação assimétrica sobre a ideia inovadora, dificilmente aceitará a revelação sem que haja cláusulas contratuais de sigilo e confidencialidade.

${ }^{87}$ SZTAJN, Rachel. Direito e Economia dos contratos. Os conceitos fundamentais. In: VERÇOSA, Haroldo M. D. Curso de direito comercial. São Paulo: Malheiros, Vol. 4, 2011, p. 85.

${ }^{88}$ Segundo a teoria dos jogos, a informação é completa quando é de conhecimento comum (common knowledge) das partes. Para FIANI, há conhecimento comum quando "todos os jogadores conhecem a
} 
momento a partir do qual o negócio passa a operar com novos sócios. Com a perspectiva de término do jogo, as partes podem adotar comportamento oportunista visando a se apropriar de maior parcela dos ganhos antes da venda do negócio finalizado. Na etapa de desinvestimento é situação que costuma beneficiar o investidor com maior frequência que o empreendedor, porque, nesta etapa, a informação assimétrica favorece o primeiro.

O investidor pode desejar a exclusão do empreendedor pouco antes do final do projeto, quando puder prescindir de seu trabalho técnico, pois assim consegue ampliar seus ganhos no momento da venda do empreendimento. O investidor liquida sua participação no ne gócio e, como há maior parcela do retorno nessa etapa, há incentivos para adotar comportamento oportunista visando a valorizar os ganhos obtidos com a venda, em prejuízo do empreendedor.

As principais formas de oportunismo são: 1) valorizar artificialmente o empreendimento; 2) apressar a venda de negócio ainda não concluído (estratégia de grandstanding); 3) diluir a participação do empreendedor antes da venda.

A primeira, a valorização artificial do empreendimento, visa a oferecer preços mais elevados aos potenciais compradores, e pode ocorrer por meio da manipulação da avaliação do negócio. Como o comprador costuma ser bem informado e antecipa esse comportamento do investidor, este deve sinalizar ao potencial comprador que não se desfará completamente de sua participação no negócio, mantendo parte dos recursos aplicados por determinado período após a conclusão da operação de venda.

A segunda forma (grandstanding) refere-se aos incentivos para o investidor apressar a venda, visando a construir sua reputação ou realizar lucros mais rapidamente, mesmo quando o projeto ainda não está completamente finalizado. A antecipação pode prejudicar o empreendedor e os terceiros compradores, porque o negócio entra em operação no mercado sem possuir todas as condições necessárias para sua manutenção.

informação, todos os jogadores sabem que todos os jogadores conhecem a informação, todos os jogadores sabem que todos os jogadores sabem que todos os jogadores conhecem a informação e assim por diante, até o infinito”. (FIANI, Ronaldo. Teoria dos jogos. $2^{\mathrm{a}}$ ed., São Paulo: Campus, 2006, p. 80). 
A atitude pode sinalizar ao mercado que o empreendimento tem desempenho inferior às expectativas, ao passo que o desinvestimento realizado ao final do projeto tende a sinalizar o sucesso do investimento. GOMPERS e LERNER explicam que o investidor com reputação estabelecida no mercado tende a ser mais conservador, rejeitando alternativas arriscadas, ao passo que o investidor sem reputação consolidada tende a assumir maiores riscos. Consequentemente, o investidor inexperiente tende a realizar o grandstanding com maior frequência, visando a sinalizar um caso de sucesso, mesmo que o projeto ainda não esteja finalizado ${ }^{89}$.

A terceira forma de oportunismo é a diluição da participação do empreendedor antes da realização da venda. Nesse caso, o investidor vale-se de informação assimétrica a respeito das condições do mercado e da venda do negócio para viabilizar o exercício da vantagem no momento do desinvestimento. A diluição pode não ser completamente percebida pelo empreendedor no momento da contratação do negócio. Normalmente, a redação das cláusulas contratuais é complexa, assim como a forma de cálculo do valor das participações, podendo induzir as partes a erro sobre a expectativa de retorno.

A operação de saída pode tomar a forma de oferta pública ou venda privada de controle do negócio. Há diferentes custos e benefícios para adoção de uma ou outra forma, que podem modificar o interesse do mercado ou o valor do negócio, afetando o retorno sobre o investimento. No caso de venda privada de controle, a forma mais comum, o investidor pode fornecer informação privilegiada sobre a venda a um terceiro de sua confiança, visando a extrair benefícios na negociação, que serão repartidos posteriormente entre o comprador e o investidor.

${ }^{89}$ GOMPERS, Paul A.; LERNER, Josh. The venture capital cycle. $2^{\text {nd }}$ ed., Cambridge: MIT Press, 2006, pp. 23-25. 


\section{TIPOS CONTRATUAIS}

\section{III.1. Critérios para análise}

A análise que empreendemos parte da premissa de ser possível encontrar um modelo ideal para organizar, de forma eficiente, o negócio de venture capital, a partir dos tipos contratuais legalmente predispostos. $\mathrm{O}$ modelo deve ser capaz de viabilizar a captação de recursos de terceiros, limitar o alto grau de incerteza do empreendimento e possibilitar a obtenção de retorno positivo sobre o investimento.

BOBBIO ensina que o modelo contratual deve ser a estrutura apta a desempenhar uma função econômica específica ${ }^{90}$, ou seja, um tipo contratual que permita organizar e desenvolver o negócio de venture capital. ROPPO denomina de “veste jurídica" o modelo contratual adequado à função econômica ${ }^{91}$.

A ideia de contrato "ideal" corresponde à necessidade de encontrar arranjo jurídico "eficiente" para organizar o empreendimento. Com base na Teoria da Escolha Racional empregamos o termo "eficiência" para indicar o melhor acordo para viabilizar o projeto a partir das preferências dos agentes econômicos, limitados pelas restrições existentes. Trata-se de critério de eficiência alocativa ${ }^{92}$, isto é, de destinação dos recursos visando à obtenção de maior retorno para o projeto, dados os riscos existentes e que resulte em maior produtividade ou rendimento do investimento.

A noção de contrato "ideal" remete à de "modelo", construção abstrata usada para analisar sua essência e principais elementos. Um modelo enfatiza as relações internas entre seus componentes e os principais fatores determinantes de suas alterações. Os limites do modelo, ou “fronteiras", determinam suas relações externas ${ }^{93}$.

Modelo é forma de simplificação da realidade, pois privilegia determinados

\footnotetext{
${ }^{90}$ BOBBIO, Norberto. Da estrutura à função: novos estudos de teoria do direito. São Paulo: Manole, 2007, pp. 13-17; 23-24.

ROPPO, Vincenzo. Il contrato. Milano: Ed. Giuffrè, 2001, pp. 72-73.

92 Conceito apresentado no Capítulo II.

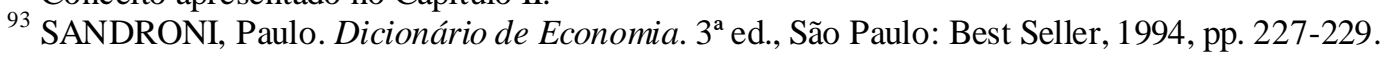


aspectos de um problema, em detrimento de outros. Permite analisar novas relações entre situações preexistentes, buscando formular regras gerais de comportamento. É frequentemente utilizado pelos legisladores e aplicadores do Direito como, por exemplo, o disposto no artigo 1.011 do Código Civil ${ }^{94}$ e nos artigos 68 e 153 da lei acionária", que adotam "modelo" de homem ativo e probo como referência para orientar a conduta dos agentes.

Um modelo tem a finalidade de identificar situações determinadas, indicando alternativas de solução a partir das premissas estabelecidas. Serve para auxiliar os tomadores de decisão a entenderem e avaliarem os incentivos, sugerindo soluções e condutas para maximizar os resultados.

A partir dos tipos contratuais predispostos na legislação buscamos estabelecer uma "relação ordinal de preferências" entre os tipos, uma escala para gradação de sua adequação ao modelo "ideal” de negócio de venture capital, descrito no Capítulo II.

A "relação ordinal de preferências" é classificação derivada da Teoria da Utilidade Ordinal, que permite estabelecer uma ordem para escolha de alternativas. A relação ordinal coloca a alternativa que apresenta maior utilidade no ponto mais alto de uma escala comparativa e subjetiva. O termo "ordinal" indica que não se pode estabelecer a medida quantitativa de cada alternativa, mas é possível ordená-los segundo um critério comparativo ${ }^{96}$.

De acordo com a Teoria da Escolha Racional, o termo "utilidade" deriva do fato

\footnotetext{
${ }^{94}$ Código Civil, art. 1.011. O administrador da sociedade deverá ter, no exercício de suas funções, o cuidado e a diligência que todo homem ativo e probo costuma empregar na administração de seus próprios negócios. $\S 1^{\circ}$ Não podem ser administradores, além das pessoas impedidas por lei especial, os condenados a pena que vede, ainda que temporariamente, o acesso a cargos públicos; ou por crime falimentar, de prevaricação, peita ou suborno, concussão, peculato; ou contra a economia popular, contra o sistema financeiro nacional, contra as normas de defesa da concorrência, contra as relações de consumo, a fé pública ou a propriedade, enquanto perdurarem os efeitos da condenação.

${ }^{95}$ Lei n. 6.404/76, art. 68. O agente fiduciário representa, nos termos desta Lei e da escritura de emissão, a comunhão dos debenturistas perante a companhia emissora. § $1^{\circ}$ São deveres do agente fiduciário: a) proteger os direitos e interesses dos debenturistas, empregando no exercício da função o cuidado e a diligência que todo homem ativo e probo costuma empregar na administração de seus próprios bens; (...)

Art. 153. O administrador da companhia de ve empregar, no exercício de suas funções, o cuidado e diligência que todo homem ativo e probo costuma empregar na administração dos seus próprios negócios.

${ }_{96}^{96}$ SANDRONI, Paulo. Dicionário de Economia. $3^{\mathrm{a}}$ ed., São Paulo: Best Seller, 1994, p. 364.
} 
de os agentes econômicos terem preferências positivas (desejos) e negativas (aversões). Preferência, nesse sentido, é utilizada como sinônimo de interesse. Prefere-se aquilo que é mais útil ao agente, isto é, que traz maiores benefícios e/ou menores custos.

Preferências orientam a escolha de estratégias pelos agentes econômicos, visando a maximizar o resultado esperado. Relacionam-se com a forma pela qual os agentes respondem aos incentivos ${ }^{97}$ e as sanções, positivas e negativas, que integram a função promocional do direito, cuja finalidade é estimular condutas desejadas e reprimir as indesejadas ${ }^{98}$.

Para os tipos contratuais selecionados, analisamos os principais incentivos e sua capacidade de limitação dos riscos do negócio, na perspectiva dos contratantes. Para empreender a análise, entendemos que as regras predispostas no tipo legal funcionam como um "preço" a pagar para organizar o negócio, sendo que os riscos incorridos com o uso do tipo são os "custos" derivados da escolha. A partir do conceito de "risco diversificável" apresentado no Capítulo II, avaliamos se os riscos podem ter seus efeitos atenuados ou não. O risco é diversificável se for possível adotar regras de atenuação ou se for viável complementar o contrato visando a mesma finalidade. $\mathrm{O}$ risco será não diversificável se a norma predisposta no tipo não for adequada e também não admitir substituição ou complementação pelo contrato.

A análise dos tipos contratuais é feita em ordem crescente de complexidade. Iniciamos pelos tipos não societários para, em seguida, abordarmos os societários. Avaliamos os aspectos mais relevantes de cada tipo, suficientes para elaborar a escala ordinal de preferências, sem pretender esgotar a análise.

A escala é construída a partir de avaliação sobre o "grau de adequação" do tipo legal às necessidades dos negócios de venture capital. Os tipos contratuais são

\footnotetext{
${ }^{97}$ DAVIS explica que a dificuldade desse tipo de análise é alinhar as preferências individuais e coletivas. O problema foi formalizado por KENNETH ARROW no Teorema da Impossibilidade, que estabelece ser impossível garantir o alinhamento dos dois tipos de preferências quando a ordem de escolha das alternativas influencia os resultados. (DAVIS, Morton D. Teoria dos jogos - uma introdução não técnica. Tradução: Leonidas Hezenberg. São Paulo: Cultrix, 1973, pp. 207-208).

${ }^{98}$ BOBBIO, Norberto. Da estrutura à função: novos estudos de teoria do direito. São Paulo: Manole, 2007, pp. 13-17; 23-24.
} 
analisados em relação à sua aptidão para limitar os riscos existentes, funcionando como incentivo positivo ou negativo à adoção do tipo. Propomos três níveis:

- $\quad$ Alto: o tipo contratual é adequado ao negócio de venture capital, pois as regras legais permitem limitar os principais riscos existentes, sem necessidade de adaptação;

- $\quad$ Médio: há adequação da maioria dos elementos essenciais do tipo ao negócio de venture capital, porém há necessidade de modificação da legislação ou inclusão de cláusulas contratuais complementares; neste caso, há limitação parcial dos riscos;

- $\quad$ Baixo: a maioria dos elementos do tipo é incompatível com as características do negócio de venture capital e há limitação insuficiente dos $\operatorname{riscos}^{99}$.

\section{III.2. Evidências empíricas}

Os tipos legais potencialmente aptos a organizar o negócio de venture capital são aqueles que permitem realizar a captação de recursos de terceiros, sua aplicação nos projetos e a limitação dos riscos.

As evidências empíricas encontradas indicam que negócios de venture capital têm sido organizados a partir de tipos societários, em especial, as sociedades limitadas e anônimas.

Os demais tipos predispostos na legislação não são utilizados na prática negocial. Desenvolvemos argumentos que pretendem explicar as razões para o descarte. Descartamos os tipos gerais definidos em Direito, especialmente o mútuo, os consórcios entre sociedades previstos na lei acionária, as associações e os outros tipos

\footnotetext{
${ }^{99}$ Escala adaptada a partir da proposição de TOMASETTI JUNIOR para estudo de contratos preliminares. (TOMASETTI JUNIOR, Alcides. Execução do contrato preliminar. Tese de doutorado. São Paulo: Faculdade de Direito da USP, 1982, pp. 18; 22-25; 308).
} 
societários. Por limitações de escopo, não analisamos todos os tipos existentes, indicando apenas as principais razões para descarte dos tipos mencionados (seção III.3).

As principais evidências empíricas encontradas confirmam os argumentos apresentados ao longo do texto e são brevemente mencionadas a seguir.

O Segundo Censo Brasileiro da Indústria de Private Equity e Venture Capital, realizado pela Fundação Getúlio Vargas (GVCEPE), indica que a sociedade anônima fechada é o tipo legal mais utilizado para organização desses empreendimentos $(68,3 \%$ dos casos), seguida da sociedade limitada $(21,7 \%)$ e da companhia aberta (10\%) ${ }^{100}$.

O censo também menciona o consórcio de sociedades como alternativa para implantar estratégias de reorganização ou crescimento de empreendimentos em estágios mais avançados de desenvolvimento ${ }^{101}$, o que não é o caso dos projetos de venture capital que estudamos.

A Latin America Venture Capital Association (LAVCA), em especial, nos documentos de scorecard e nos guias para elaboração de contratos ${ }^{102}$ de venture capital baseiam suas recomendações na estrutura contratual da sociedade anônima fechada.

As entrevistas que realizamos com operadores do mercado de venture capital resultaram na avaliação de quarenta empreendimentos com escopo e porte variados, para projetos de base tecnológica, isto é, desenvolvimento de produtos e serviços voltados para tecnologia da informação, telecomunicações e desenvolvimento de

\footnotetext{
${ }^{100}$ Fundação Getúlio Vargas (GVCEPE). A indústria de private equity e venture capital - segundo censo brasileiro. $1^{\text {a }}$ Ed., Março/2011. Disponível em: <http://gvcepe.com/>. Acesso em: 03.04.2012, pp. 273-275.

${ }^{101} \mathrm{O}$ censo aponta que as decisões de reposicionamento estratégico são tomadas algum tempo depois da entrada do investidor no negócio e caracterizam-se por serem ações de reestruturação, ou turn-around (22\% dos casos analisados), empreendimentos conjuntos (joint ventures, com 9\%) e aquisições de outros negócios. Os principais motivos para realização de joint ventures são: 1) necessidade de aumentar o mercado de alcance (75\% dos casos); necessidade de preparar a sociedade para desinvestimento (25\% dos casos). (Fundação Getúlio Vargas (GVCEPE). A indústria de private equity e venture capital - segundo censo brasileiro. $1^{\text {a }}$ Ed., Março/2011. Disponível em: <http://gvcepe.com/>. Acesso em: 03.04.2012, pp. 310-311).

${ }^{102}$ LAVCA (Latin America Venture Capital Association). The private equity and venture capital environment in Latin America - Scorecard, 2012. Disponível em: 〈www.lavca.org〉. Acesso em 19.02.2013; Guia para term sheets de venture capital e private equity, 2012. Disponível em: <www.lavca.org>. Acesso em 19.02.2013; Guia para contratos de venture capital e private equity, 2012. Disponível em: <www.lavca.org>. Acesso em 19.02.2013.
} 
software. Foram analisados os term sheet, carta de intenções, acordos de confidencialidade, acordos de transferência de ações, acordos de acionistas, plano de

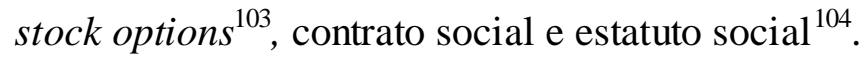

As entrevistas representam amostra viesada dos contratos, servindo apenas como indicação de tendência, porém predominou a utilização do tipo legal da sociedade anônima fechada. No caso de sociedades previamente constituídas pelo empreendedor sobre outra forma, a maioria dos entrevistados mencionou a obrigatoriedade de sua transformação para companhia fechada, a pedido dos investidores, como condição para viabilizar o aporte de recursos.

Os entrevistados relatam haver excessivas precauções contratuais visando a reduzir os riscos do negócio, causados pelos seguintes fatores: 1) deficiências dos tipos contratuais para limitação dos riscos do projeto; 2) insuficiência da estrutura institucional de incentivos à inovação, especialmente os de natureza tributária, trabalhista e previdenciária, assim como proteção inadequada aos direitos de propriedade imaterial, que afetam o preço de venda do negócio de venture capital, temas que escapam a esta tese ${ }^{105}$.

\footnotetext{
${ }^{103}$ Nas companhias, a emissão de stock options é forma utilizada para minimizar o risco de desligamento indesejado de profissionais críticos para o projeto. Trata-se de operação de emissão de opções de compra de ações da companhia, concedidas gradualmente a um grupo determinado de empregados, com caráter remuneratório, cujo exercício se protrai no tempo e é condicionado à manutenção do vínculo contratual entre a companhia e o empregado. É opção com cláusula condicional de exercício do direito nela contido, dependente do decurso de certo lapso temporal estabelecido pela companhia emissora, desde que não haja interrupção do vínculo trabalhista ou contratual com o beneficiado. O plano de opção de compra de ações reserva parte das ações da sociedade para serem oferecidas aos empregados, com o objetivo de fornecer incentivo para sua permanência, atribuindo-lhes participação nos resultados da sociedade. (LAVCA (Latin America Venture Capital Association). Guia para term sheets de venture capital e private equity, 2012. Disponível em: <www.lavca.org>. Acesso em 19.02.2013, pp. 8; 24-25).

${ }^{104}$ Detalhamento dos acordos no Anexo VI.1.

${ }^{105}$ A preservação dos bens intangíveis produzidos pelo empreendimento é fator crítico para o sucesso do projeto de venture capital, podendo essa proteção ser obtida por meio de patente de invenção ou acordos de segredo industrial. A proteção depende da legislação existente que, por sua vez, depende do tipo de invenção desenvolvida. A proteção varia caso se trate, por exemplo, de software, fármaco ou biotecnologia, aplicandose, no que couber, a Lei n. 9.279/96 (Código de Propriedade Industrial). Os direitos de propriedade imaterial afetam o preço de venda do negócio e compõe o valor do ágio sobre a rentabilidade futura (goodwill), que é a diferença entre o valor do negócio como um todo e o valor dos ativos que o compõem. Ele não se destaca do empreendimento em que foi produzido e somente pode ser reconhecido quando da venda do negócio a terceiros, pois se justifica pela possibilidade de geração de lucros futuros pelo negócio. Sua avaliação depende do efeito que pretende ser alcançado pelo investidor, isto é, se proporciona influência significativa ou controle sobre o negócio adquirido. Os conceitos recebem tratamento idêntico na Contabilidade, porém as definições do Código Civil (artigos 1.097 a 1.100) diferem das indicadas na Lei das S/A (artigo 243), mas não impedem o reconhecimento do ágio. Entretanto, a interpretação dada pela legislação fiscal não coincide
} 
Listamos as principais observações extraídas das entrevistas e contratos analisados:

\section{Quanto às características gerais do negócio:}

- Investimento é de montante relativamente baixo, relativamente ao porte dos projetos;

- Objeto social parece indicar a existência de projetos com baixo grau de inovação como, por exemplo, "serviços de digitação e processamento de dados";

- Cláusulas contratuais são de redação complexa.

Quanto à contribuição dos sócios:

- Inexistência de realização da contribuição dos sócios para o capital social sob a forma de serviços;

- Contribuição do empreendedor, quando existente, em montante relativamente baixo;

Quanto à administração do ne gócio:

com as definições adotadas pelo direito societário e pela Contabilidade, havendo incerteza quanto à interpretação jurídica a ser dada ao tratamento do ágio. Neste caso, cuida-se de risco sistemático, isto é, não diversificável pelos tipos contratuais, razão pela qual não o detalhamos nesta tese. Para o tratamento do goodwill, ver: DE IUDÍCIBUS, Sérgio; MARTINS, Eliseu; GELBCKE, Ernesto Rubens; DOS SANTOS, Ariovaldo, Manual de contabilidade societária. 1a ed., São Paulo: Atlas, 2010, pp. 193-194; 200; 264; MARTINS, Eliseu; IUDÍCIBUS, Sérgio de. Intangível - sua relação contabilidadeldireito - teoria, estruturas conceituais e normas - problemas fiscais de hoje. In: MOSQUERA, Roberto Quiroga; LOPES, Alexsandro B. (org.). Controvérsias Jurídico-Contábeis (Aproximações e Distanciamentos). São Paulo: Dialética, 2011, pp. 75-76; MOSQUERA, Roberto Quiroga; FREITAS, Rodrigo de. Aspectos polêmicos do ágio na aquisição de investimento: (i) rentabilidade futura e (ii) ágio interno. In: MOSQUERA, Roberto Quiroga; LOPES, Alexsandro B. (org.). Controvérsias Jurídico-Contábeis (Aproximações e Distanciamentos). Vol. 2, São Paulo: Dialética, 2011, pp. 261-263; 279-280. 
- Ações ordinárias e preferenciais com direito de voto restrito a matérias especificadas no estatuto social;

- Participação do empreendedor na admi nistração direta do negócio;

- Designação de administradores não sócios para representar o investidor;

- Conselho de administração, quando existente, com membros indicados pelo empreendedor, pelo investidor ou compartilhados, com eleição de membros e orientação de voto vinculado a acordo de acionistas;

- Preferência por número ímpar de conselheiros, minimizando a possibilidade de empate em deliberações;

- Quoruns deliberativos elevados para determinadas matérias, com estabelecimento de direito de veto em favor do investidor;

- Dividendo obrigatório anual com previsão de distribuição em estatuto social apresentando, em alguns casos, percentual significativo sobre o valor do lucro líquido do exercício social;

- Exigência de competências e qualidades específicas para ocupar cargos da diretoria e conselho de administração;

- Indicação, exclusivamente pelo investidor, de representantes para ocupar os cargos de diretor financeiro e de marketing;

- Conselho fiscal de instalação e funcionamento obrigatórios;

- Acordos de acionistas com duração maior que a prevista para o empreendimento como um todo.

Quanto à negociação de direitos: 
- Cláusulas estabelecendo direito de preferência, tag along e drag along;

- Acordos para conversão de espécies de ações, sua permuta e alienação;

- Previsão de restrição temporária à circulação de ações;

- Regras para emissão de opções para aquisição de ações em favor dos empregados da sociedade (stock options);

- Direito de resgate ou devolução dos recursos, em favor do investidor;

- Cláusulas autorizando aumento futuro de capital;

- Cláusulas para proteção à propriedade imaterial discriminando os direitos antes e depois da contratação do negócio;

- Cláusulas de "não competição" ("quarentena") vigentes por prazo elevado, submetendo o empreendedor;

- Cláusulas de sigilo e confidencialidade de informações aplicáveis a sócios e empregados;

- Acordos de segredo industrial versando sobre a tecnologia desenvolvida.

Quanto à venda do negócio:

- Hipóteses para cálculo do valor do negócio em caso de desinvestimento: valor patrimonial; valor de mercado; valor arbitrado pelas partes ou por terceiros previamente indicados;

- Possibilidade de haver conversibilidade de ações preferenciais em ordinárias, no momento da venda. 
Nos contratos analisados, percebe-se a existência de excessiva proteção contra os riscos do negócio, em favor do investidor, mesmo nos casos em que o montante investido não parecia ser significativo.

\section{III.3. Tipos descartados}

Preliminarmente, entendemos inaplicável a disciplina dos contratos preliminares, previstos pelo artigo 462 do Código Civil. Contratos preliminares seriam úteis para preparar a contratação futura do negócio de venture capital, garantindo acordos parciais sobre temas críticos do projeto, enquanto as negociações definitivas não são concluídas pelas partes. Defendemos sua inaplicabilidade porque o Código Civil torna obrigatória a repetição das cláusulas essenciais e acidentais no contrato definitivo ${ }^{106,107,108}$, situação que inviabiliza seu uso em projetos de venture capital, normalmente sujeitos à realização de investigação preliminar sobre o negócio (atividade de due diligence) e tratativas que podem resultar em modificação do contrato definitivo.

\footnotetext{
${ }^{106}$ TOMASETTI JÚNIOR já indicava, em 1982, tendência jurisprudencial no sentido de igualar o contrato preliminar ao definitivo. (TOMASETTI JUNIOR, Alcides. Execução do contrato preliminar. Tese de doutorado. São Paulo: Faculdade de Direito da USP, 1982, pp. 27-32). A doutrina sempre divergiu a respeito de saber se a norma alcançava somente as condições essenciais ou também incluía as acidentais, conforme destacado em: PENTEADO, Mauro R. Formação de contrato preliminar suscetível de adjudicação compulsória. Revista de Direito Mercantil, Industrial, Econômico e Financeiro, Ano XIX, n. 39, Jul./Set. 1980, p. 182.

${ }^{107}$ No Recurso Extraordinário n. 88.716, Segunda Turma, Rio de Janeiro, DJ 30.11.1979, Ementário n. 1.155-2 (Pão de Açúcar X Supermercados Disco), proposto ainda na vigência do Código Civil e do Código Comercial de 1850, o voto da maioria dos ministros acompanhou o Ministro-relator Moreira Alves, que concluiu pela obrigatoriedade de repetição de todas as cláusulas essenciais e acidentais para que se configure o contrato preliminar. Merecem atenção também as passagens dos votos nas quais os Ministros debatem a natureza do contrato preliminar. (especialmente, páginas 141, 142, 147, 148, 149, 150, 153, 166, 167). (PENTEADO, Mauro R. Formação de contrato preliminar suscetível de adjudicação compulsória. Revista de Direito Mercantil, Industrial, Econômico e Financeiro, Ano XIX, n. 39, pp. 136-183, Jul/Set. 1980). Ver também: PELA, Juliana K. O contrato preliminar. Revista de Direito Mercantil Industrial Econômico e Financeiro, São Paulo, Ano XLII, v. 130, Abr./Jun. 2003, pp. 231-232.

${ }^{108}$ A obrigatoriedade se mantém com a atual jurisprudência. Exemplo mencionando a obrigatoriedade de repetição de todas as cláusulas contratuais: TJ-SP $-32^{\mathrm{a}}$ Câmara de Direito Privado, Agravo de Instrumento $\mathrm{n}^{\mathrm{o}}$ 0105075-48.2011.8.26.0000, Comarca de Piracicaba, Data: 30.06.2011, Agravante: Luiz Maluf Zaidam, Agravado: Selma Regina Novoletto, Disponível em:<www.aasp.org.br〉, Acesso em: 28.12.2012; TJ -SP - 2 ${ }^{\mathrm{a}}$ Câmara de Direito Privado, Apelação n ${ }^{\circ}$ 0004991-88.2010.8.26.0577, Comarca de São José dos Campos, Data: 05.04.2011, Apelante: Valderez Haas, Apelado: Rodrigo Amaral Lopes Beviláqua e outros, Disponível em:<www.aasp.org.br>, Acesso em: 28.12.2012. Mencionando a aplicabilidade somente aos requisitos essenciais: TJ-SP $-6^{\mathrm{a}}$ Câmara de Direito Privado, Apelação no 994.09.282457-6, Comarca de Araraquara, Data: 04.02.2010, Apelantes: Maria Elisa de Oliveira Mode, Aylton Antônio Mode, Vera de Oliveira Terra, Eduardo Augusto Terra, Vera Maria Terra Jalbut e Celso Jalbut, Apelado: Antônio José de Andrade Filho, Disponível em:<www.aasp.org.br>, Acesso em: 28.12.2012.
} 


\section{III.3.1. Mútuo}

O Título VI do Livro I da Parte Especial do Código Civil elenca as diversas espécies de contrato que tutelam obrigações, como por exemplo, a compra e venda, doação, prestação de serviços, etc. Estes tipos devem ser descartados porque não são aptos a organizar negócios plurilaterais de escopo comum e sujeitos a alto grau de incerteza, como é o caso de empreendimentos de venture capital. Também os empréstimos, em especial aqueles sob a forma de mútuo (artigos 586 a 592 do Código Civil), que têm sido utilizados na prática negocial para captação de recursos de terceiros visando ao financiamento de projetos, são inadequados, pelas razões expostas a seguir.

Nos contratos de mútuo há duas partes, mutuante e mutuário. Contratos de mútuo são onerosos, havendo transferência de recursos do mutuante ao mutuário, por determinado período estipulado em contrato ${ }^{109}$. Se o prazo não for estipulado, não pode ser inferior a trinta dias. Cabe ao mutuário desenvolver, com exclusividade, a atividade e assumir obrigação de devolver o valor, acrescido de remuneração. Ao mutuante assiste o direito de exigir a prestação do mutuário nos termos avençados ${ }^{110}$. O mutuante também pode exigir garantia da restituição se antes do vencimento do contrato o mutuário sofrer notória mudança em sua situação econômica que sinalize a impossibilidade de devolução dos valores devidos ${ }^{111}$. Não há vencimento antecipado da dívida, exceto em hipóteses específicas ${ }^{112}$.

\footnotetext{
${ }^{109}$ Código Civil, artigo 586. O mútuo é o empréstimo de coisas fungíveis. O mutuário é obrigado a restituir ao mutuante o que dele recebeu em coisa do mesmo gênero, qualidade e quantidade.

${ }^{110}$ Código Civil, artigo 587. Este empréstimo transfere o domínio da coisa emprestada ao mutuário, por cuja conta correm todos os riscos dela desde a tradição. Artigo 591. Destinando-se o mútuo a fins econômicos, presumem-se devidos juros, os quais, sob pena de redução, não poderão exceder a taxa a que se refere $o$ art. 406, permitida a capitalização anual. Artigo 592. Não se tendo convencionado expressamente, o prazo do mútuo será: (...) II - de trinta dias, pelo menos, se for de dinheiro.

${ }^{111}$ Código Civil, artigo 590. O mutuante pode exigir garantia da restituição, se antes do vencimento o mutuário sofrer notória mudança em sua situação econômica.

${ }^{112}$ Código de Processo Civil, artigo 333. "Ao credor assistirá o direito de cobrar a dívida antes de vencido o prazo estipulado no contrato ou marcado neste Código: I - no caso de falência do devedor, ou de concurso de credores; II - se os bens, hipotecados ou empenhados, forem penhorados em execução por outro credor; III se cessarem, ou se se tornarem insuficientes, as garantias do débito, fidejussórias, ou reais, e o devedor, intimado, se negar a reforçá-las. Parágrafo único. Nos casos deste artigo, se houver, no débito, solidariedade passiva, não se reputará vencido quanto aos outros devedores solventes".
} 
No mútuo bancário, modalidade mais utilizada no mercado, o mutuante é instituição bancária e o objeto do negócio é quantia em dinheiro cuja propriedade é transferida para o mutuário, com obrigação de pagar os juros convencionados e a restituir os valores devidos ao final do prazo ${ }^{113,114}$. A operação se aperfeiçoa com a entrega da quantia ao mutuário ${ }^{115}$ e distingue-se do financiamento bancário pela ausência de finalidade específica para uso dos recursos ${ }^{116}$.

Os recursos obtidos por meio de contrato de mútuo não são permanentes, portanto, não podem ser capitalizados pelo mutuário. Como se trata de passivo do tomador dos recursos, não integra o patrimônio líquido contábil do mutuário.

O mútuo não é negócio plurilateral, razão pela qual não é apto a organizar a atividade em comum entre o empreendedor e o investidor de venture capital. Os elementos que caracterizam um negócio plurilateral foram apresentados no Capítulo II, indicando que o contrato de mútuo não tem o condão de estabelecer a cooperação requerida entre o empreendedor e o investidor para o desenvolvimento da atividade. $\mathrm{O}$ mutuante tem somente interesse na recuperação dos recursos emprestados, pois não pretende assumir riscos derivados da execução do empreendimento. Consequentemente, o mutuário desenvolve, com exclusividade, sua atividade, e ao mutuante assiste o direito de receber, ao final do prazo do contrato de mútuo, os valores emprestados acrescidos dos juros e encargos estipulados.

\footnotetext{
113 “(...) o elemento comum a todos os negócios de crédito reside em quatro prestações simetricamente contrapostas: a entrega que tem sua contraprestação na restituição; o prazo, cuja prestação correspectiva está no pagamento de juros, já que estes representam o preço do tempo concedido". (MELLO FRANCO, Vera H., Contratos - direito civil e empresarial. São Paulo: Ed. Revista dos Tribunais, $3^{\text {a }}$. ed., 2012, pp. 151-153).

${ }^{114}$ Há duas modalidades de mútuo bancário relevantes para a discussão em tela: empréstimo para capital de giro, vinculado a um contrato específico com prazo de até 180 dias, normalmente garantido por títulos de crédito; mútuo bancário, com prazo superior a 180 dias, acompanhado de prestação de garantias. As garantias são exigidas nas duas modalidades e, aliadas à informação sobre a solvência do tomador de crédito, determinam a decisão de emprestar e a taxa de juros aplicada à operação. (FORTUNA, Eduardo. Mercado financeiro - produtos e serviços. $18^{\mathrm{a}}$ ed., Rio de Janeiro: Qualitymark, 2010, pp. 225-226; 250-251).

${ }_{115}$ MELLO FRANCO, Vera H., Contratos - direito civil e empresarial. São Paulo: Ed. Revista dos Tribunais, $3^{\text {a }}$ ed., 2012, pp. 154-155; 162-163.

${ }^{116}$ Financiamento bancário distingue-se do empréstimo pelo escopo específico de uso dos recursos e pelo oferecimento de garantias, presentes no primeiro. (NERY JÚNIOR, Nelson; NERY, ROSA M. de A. Código civil comentado. $7^{\text {a }}$ Ed., São Paulo: Revista dos Tribunais, 2009, p. 626).
} 


\section{III.3.2. Consórcio}

Joint venture é negócio em comum cuja definição é influenciada pela prática negocial e por construções jurisprudenciais. BAPTISTA explica que a expressão deriva do termo adventure, evolui para joint adventure até alcançar a forma atual de joint venture. É negócio associativo, voluntário, de risco, temporário, com objetivo de lucro, voltado para o desenvolvimento de um único empreendimento, normalmente de grande porte $^{117,118,119}$.

Uma das espécies de joint venture é o consórcio, previsto na lei acionária ${ }^{120}$. O artigo 278 da lei posiciona ${ }^{121}$ o consórcio entre os contratos de associação entre duas ou mais sociedades preexistentes, de qualquer tipo, voltados para executar empreendimento específico, sem constituição de pessoa jurídica, no qual as consorciadas somente se obrigam nos termos previstos em contrato, respondendo, cada

${ }^{117}$ BAPTISTA aponta haver diversas definições de joint venture, referindo-se a comenda, associação, sociedade de participação ou sociedade com escopo limitado a um único negócio, etc. $\mathrm{O}$ autor indica que, no direito americano atual, a definição de joint venture tem sido buscada em sede jurisprudencial, para distinguila das sociedades e de outras formas associativas contratuais. (BAPTISTA, Luiz O. A "joint venture" - uma perspectiva comparatista. Revista de Direito Mercantil Industrial Econômico e Financeiro, São Paulo, Ano XX, v. 42, Abr./Jun. 1981, pp. 39-43; 53).

118 'Essas, e outras características - como a formação de mercados regionais que são mais bem atendidos quando as empresas associam suas forças - têm levado não só empresários, mas também os legisladores e procurarem novas formas de associações que possam responder a essas necessidades. As joint ventures (...) formam por certo uma das primeiras manifestações dessas conveniências empresariais: e se formaram, seja associando empresas numa terceira corporação, seja constituindo partnerships (sem personalidade jurídica) para a realização dessa buscada cooperação". (LAMY FILHO, Alfredo; BULHÕES PEDREIRA, José L., A lei das S/A: (pressupostos, elaboração, aplicação). Rio de Janeiro: Renovar, 1992, p. 98).

${ }^{119}$ Ver também: PENTEADO, Mauro R. Associações voluntárias de empresas - uma análise da legislação no país e no exterior. Revista de Direito Mercantil Industrial Econômico e Financeiro, São Paulo, Ano XXII, v. 52, pp. 44-63, Out./Dez. 1983.

${ }^{120}$ Os pareceres apresentados durante a elaboração da Lei das S/A esclarecem que a constituição do empreendimento comum pose ser denominada "joint venture", "sociedade de sociedades", "filial comum", "associação de empresas", "co-empresa", ou outra designação, todas fundadas em um "acordo de base", chamado de "acordo moldura", a que se acrescem acordos subsidiários. (LAMY FILHO, Alfredo; BULHÕES PEDREIRA, José L., A lei das S/A: (pressupostos, elaboração, aplicação). Rio de Janeiro: Renovar, 1992, p. 411).

${ }^{121}$ Lei n. 6.404/76, artigo 278. As companhias e quaisquer outras sociedades, sob o mesmo controle ou não, podem constituir consórcio para executar determinado empreendimento, observado o disposto neste Capítulo. $\$ 1^{\circ} \mathrm{O}$ consórcio não tem personalidade jurídica e as consorciadas somente se obrigam nas condições previstas no respectivo contrato, respondendo cada uma por suas obrigações, sem presunção de solidariedade. $\$ 2^{\circ} \mathrm{A}$ falência de uma consorciada não se estende às demais, subsistindo o consórcio com as outras contratantes; os créditos que porventura tiver a falida serão apurados e pagos na forma prevista no contrato de consórcio. 
uma, por suas próprias obrigações ${ }^{122,123}$. O arti go 279 indica os principais elementos e características do contrato: designação; objeto; duração; foro aplicável; direitos e deveres das partes; normas sobre alocação de custos e partilha de resultados; regras para administração e deliberação ${ }^{124}$.

O consórcio de sociedades, predisposto na lei acionária, não é tipo legal adequado para estruturar negócios de venture capital, pelas seguintes razões: 1) necessidade de preexistência das sociedades participantes e ausência de personalidade jurídica própria do consórcio; 2) incerteza quanto à interpretação dada ao controle conjunto do negócio; 3) transitoriedade do empreendimento.

1)

Preexistência das sociedades participantes e ausência de personalidade jurídica própria do consórcio

De acordo com LAMY FILHO e BULHÕES PEDREIRA, nos consórcios da lei acionária não há participação de pessoa natural, somente de $\operatorname{sociedades}^{125}$, que são independentes e se reúnem para conduzir o empreendimento comum, partilhando riscos e resultados ${ }^{126}$. Neste caso, há dificuldades para uso do consórcio em negócios de venture capital, porque o projeto somente seria viabilizado se o empreendedor e o

${ }^{122}$ TJ-SP, $5^{\text {a }}$ Câmara - Seção de Direito Privado. Apelação N. 2 281.831.4/8-00 - Voto N. 213642. Comarca: São Paulo (22 ${ }^{\mathrm{a}}$ V. Cível - Proc. N. 2 14602/2001). Recorrente(s): MG NE do Brasil Ltda. Recorrido(s): Industrial Comercial de Plásticos Engplastic Ltda.: “(...) Joint venture pode ser definida, em termos simples, como uma parceria entre empresas, não definitiva e com fins lucrativos, para a exploração de determinada ati vidade, sem que nenhuma delas perca sua personalidade jurídica própria. Uma operação desta natureza, complexa, envolvendo tantos interesses, por certo e logicamente seria instrumentalizada em contrato devidamente registrado e não ficaria adstrito apenas ao plano verbal. (...)".

${ }^{123}$ Ver também: BULGARELLI, Waldirio. Manual das sociedades anônimas. $9^{\mathrm{a}}$ Ed., São Paulo: Atlas, 1997, p. 312; GUERREIRO, José A. T. Regime jurídico do consórcio. Revista de Direito Mercantil Industrial Econômico e Financeiro, São Paulo, Ano XLIV, v. 138, Abr./Jun. 2005, pp. 202-203.

${ }^{124}$ Lei n. 6.404/76, artigo 279. O consórcio será constituído mediante contrato aprovado pelo órgão da sociedade competente para autorizar a alienação de bens do ativo não circulante, do qual constarão: I - a designação do consórcio se houver; II - o empreendimento que constitua o objeto do consórcio; III - a duração, endereço e foro; IV - a definição das obrigações e responsabilidade de cada sociedade consorciada, e das prestações específicas; V - normas sobre recebimento de receitas e partilha de resultados; VI - normas sobre administração do consórcio, contabilização, representação das sociedades consorciadas e taxa de administração, se houver; VII - forma de deliberação sobre assuntos de interesse comum, com o número de votos que cabe a cada consorciado; VIII - contribuição de cada consorciado para as despesas comuns, se houver. Parágrafo único. O contrato de consórcio e suas alterações serão arquivados no registro do comércio do lugar da sua sede, devendo a certidão do arquivamento ser publicada.

${ }^{125}$ LAMY FILHO, Alfredo; BULHÕES PEDREIRA, José L., A lei das S/A: (pressupostos, elaboração, aplicação). Rio de Janeiro: Renovar, 1992, p. 79.

${ }^{126}$ LAMY FILHO, Alfredo; BULHÕES PEDREIRA, José L., Op.cit., pp. 97-99. 
investidor constituírem, cada qual, uma sociedade em separado para, então, celebrarem o negócio consorcial. Entretanto, muitas vezes o empreendedor sequer constitui pessoa jurídica antes de solicitar recursos ao investidor para evitar incorrer em custos antes de obter os recursos necessários para desenvolvimento das atividades.

A obrigatoriedade de existência de sociedades pré-constituídas por cada um dos contratantes como pré-requisito para celebração do negócio consorcial demonstra que este é mais apto a organizar empreendimentos voltados para cadeias produtivas que estejam em funcionamento, o que não é o caso de negócios de venture capital, nos quais a inovação pressupõe o desenvolvimento de nova forma de organização da produção.

O consórcio somente é estabelecido quando há manifesta intenção das partes por sua criação, com indicação precisa da forma de união de recursos, conhecimento, riscos e interesses, visando a distingui-lo dos demais negócios firmados entre os participantes, a limitar a responsabilidade individual e a criar deveres específicos de lealdade entre os contratantes. Parte da jurisprudência nacional vem reconhecendo esses requisitos como essenciais ao negócio ${ }^{127}$.

A responsabilidade dos consorciados pode ser mais ampla do que a assumida se as partes adotassem tipos societários personificados, o que acaba por funcionar como desestímulo à adoção desse tipo contratual em negócios de venture capital. $\mathrm{O}$ artigo 278 da lei acionária estabelece que a responsabilidade individual de cada consorciado restrinja-se às obrigações contratadas com terceiros, porém em nome próprio. A responsabilidade do consórcio perante terceiros é plena, isto é, todos os consorciados

${ }^{127}$ TJ-SP, $5^{\text {a }}$ Câmara de Direito Privado do Tribunal de Justiça de São Paulo. Ap. no 994.03.073659-0. Comarca de Piracicaba. Apelantes: Elring Klinger G M BH e Elring Klinger do Brasil Ltda. Apelado: Maquejunta Indústria e Comércio do Brasil Ltda.

EMENTA - Contrato - Negociações entre empresa alemã e empresa brasileira para criação de uma "joint venture" no Brasil, para industrialização de produtos com a tecnologia alemã e utilização dos conhecimentos do mercado e posição da sociedade brasileira - Farta documentação e assinatura de protocolo de intenções que deixa patente as tratativas das partes - Rompimento unilateral e imotivado das negociações pela empresa alemã com imediata criação de sociedade brasileira, da qual é titular de $99 \%$ do capital social - Rompimento da boa-fé objetiva que deve nortear o proceder das partes - Concorrência desleal praticada pela nova sociedade, que possui conhecimento da estratégia industrial e comercial da autora - Indenização devida Indenização a ser liquidada por arbitramento, com exclusão de alguns itens considerados na R. Sentença apelada. (grifos nossos). 
respondem pela obrigação daquele que contratou diretamente com terceiro, mas os bens do contratante respondem pelas obrigações assumidas em nome próprio, sendo subsidiária a responsabilidade dos demais. Tal situação é indesejada pelos participantes de negócios de venture capital, porque amplia os riscos individuais assumidos.

Incerteza quanto à interpretação dada ao controle conjunto do negócio

O inciso VI do artigo 278 da lei acionária estabelece que o contrato de consórcio pode definir normas sobre administração do empreendimento comum, contabilização e representação das sociedades consorciadas. A lei autoriza a nomeação de gerentes, que podem atuar como representantes dos consorciados e realizar as atividades, com possibilidade de remuneração pela execução, que a lei denomina "taxa de administração".

Os pareceres elaborados durante a discussão do anteprojeto da Lei das S/A indicavam que o legislador pretendia afastar do contrato de consórcio a obrigatoriedade de atribuir o controle sobre o empreendimento a apenas um dos participantes ${ }^{128}$. Segundo os autores do anteprojeto, esta característica diferenciaria os consórcios das sociedades, pois, nestas, geralmente, a titularidade da maioria do capital votante implica em obtenção do controle, ao passo que naqueles a administração do negócio é comum, o que implicaria em deliberações tomadas em conjunto e controle do empreendimento exercido em comum ${ }^{129}$. O inciso VII do artigo 278 da lei acionária

\footnotetext{
128 'Em verdade, a realização de um 'empreendimento comum' importa excluir a noção de controle, que fica, necessariamente, dividido entre os 'partners': se existe controle de um dos sócios (...) não há "empreendimento comum"'. (LAMY FILHO, Alfredo; BULHÕES PEDREIRA, José L., A lei das S/A: (pressupostos, elaboração, aplicação). Rio de Janeiro: Renovar, 1992, p. 413).

129 "Como se comprova, por tudo quanto foi dito, na 'joint venture' não existe controle por parte de um dos sócios: é da essência do empreendimento comum que o controle seja dividido, que um partícipe não prevaleça sobre o outro, que as relações entre os mesmos se façam em pé de igualdade. Essa característica é que distingue as sociedades fechadas, que se tornam instrumentos das 'joint ventures', das sociedades anônimas, em geral: é que estas últimas (ao contrário daquelas) são criadas para funcionar sob o império da lei de maioria, da prevalência do princípio majoritário, sem o qual - sociedades de muitos sócios - elas se tornam inviáveis. Em conclusão: na sociedade anônima aberta, em geral, e, mesmo, em certas anônimas fechadas, a titularidade da maioria das ações com voto significa controle (...). Na 'joint venture', é tudo diverso: a titularidade da maioria do capital votante é irrelevante se o 'quorum' das decisões é aumentado; os cargos administrativos são previamente partilhados entre os sócios; ninguém manda sozinho, ninguém controla. O empreendimento é comum, a gestão é comum, o controle é comum”. (LAMY FILHO, Alfredo;
} 
permite que o instrumento consorcial defina a forma de deliberação sobre assuntos de interesse comum e o número de votos que cabe a cada consorciado.

Se entendermos que os consórcios exigem unanimidade das deliberações, haverá incentivo negativo para sua utilização em projetos de venture capital, pois, nestes, dependendo da etapa de desenvolvimento do projeto e da matéria sujeita a deliberação, é fundamental que preponderem as decisões tomadas pelo investidor ou pelo empreendedor.

3) Transitoriedade do empreendimento

O consórcio geralmente refere-se à realização de um único empreendimento por tempo determinado ${ }^{130}$, mas o desenvolvimento da ideia inovadora resultará em novos produtos e serviços que serão comercializados no mercado por tempo indeterminado. A organização criada para desempenhar esta atividade é cons truída ao longo do projeto de venture capital e "vendida" juntamente com os direitos sobre a ideia inovadora, ao final do projeto. A continuidade das operações após a venda contrasta com a noção de transitoriedade do consórcio.

\section{III.3.3. Sociedades e associações}

O artigo 44 do Código Civil elenca as pessoas jurídicas de direito privado: associações, sociedades, fundações, organizações religiosas, partidos políticos e empresas individuais de responsabilidade limitada.

As organizações religiosas e partidos políticos são inadequados para organizar negócios de venture capital porque desempenham funções específicas e não estão voltadas para organizar empreendimentos com finalidade de distribuição de lucros aos participantes.

BULHÕES PEDREIRA, José L., A lei das S/A: (pressupostos, elaboração, aplicação). Rio de Janeiro: Renovar, 1992, p. 414).

${ }^{130}$ BASSO, Maristela. Manual prático das associações comerciais. Porto Alegre: Livraria do Advogado, $2^{\mathrm{a}}$ ed., 1998, p. 50. 
Da mesma forma as fundações, que somente podem ter finalidade religiosa, moral, cultural ou de assistência (artigo 62 do Código Civil) e recebem um conjunto de bens livres cuja administração é obrigatoriamente supervisionada pelo Ministério Público (artigo 66).

O Código Civil, em seu artigo 53, proíbe as associações de terem finalidade econômica, ao contrário do que estabelece o artigo 981 para as sociedades. Os artigos 53, 61 e $981^{131}$, do Código Civil, determinam que a finalidade econômica caracterize as sociedades, mas não as associações. Ainda que sua conceituação seja difícil, a finalidade lucrativa, acompanhada da obrigatoriedade de partilha dos resultados entre os sócios, permite distinguir as associações das sociedades ${ }^{132}$.

As associações podem ser lucrativas, isto é, apresentar retorno positivo sobre os recursos investidos, mas não pode haver distribuição dos lucros aos associados, somente direito à restituição das contribuições sociais em caso de liquidação (artigo 61).

O parágrafo único do artigo 53 também determina não haver reciprocidade de direitos e obrigações entre os participantes de associação, ao contrário do artigo 981, que estabelece a obrigação recíproca de contribuir com bens ou serviços e direito à partilha dos resultados aos participantes de sociedade. Esta estrutura é típica de negócios de venture capital, que são projetos com alto grau de incerteza que buscam o desenvolvimento de ideia inovadora para futura comercialização, com intuito de lucro, a ser distribuído entre o empreendedor e o investidor.

As associações, definidas pelo Código Civil, são incapazes de limitar os principais riscos de projetos de venture capital pelas seguintes razões: 1) não é possível

\footnotetext{
${ }^{131}$ Código Civil, artigo 53. Constituem-se as associações pela união de pessoas que se organizem para fins não econômicos. Parágrafo único. Não há, entre os associados, direitos e obrigações recíprocos.

Artigo 61. Dissolvida a associação, o remanescente do seu patrimônio líquido, depois de deduzidas, se for o caso, as quotas ou frações ideais referidas no parágrafo único do art. 56, será destinado à entidade de fins não econômicos designada no estatuto, ou, omisso este, por deliberação dos associados, à instituição municipal, estadual ou federal, de fins idênticos ou semelhantes.

Artigo 981. Celebram contrato de sociedade as pessoas que reciprocamente se obrigam a contribuir, com bens ou serviços, para o exercício de atividade econômica e a partilha, entre si, dos resultados. (grifos nossos).

${ }^{132}$ SZTAJN, Rachel. Associações e sociedades. Revista de Direito Mercantil, Industrial, Econômico e Financeiro, Ano XLI, n. 128, Out./Dez. 2002, p. 21.
} 
terem finalidade econômica e haver distribuição de lucros aos associados (artigos 53 e 981); 2) a exclusão de associado somente é permitida em caso de justa causa (artigo $57^{133}$ ); 3) em caso de dissolução, o patrimônio remanescente deve ser obrigatoriamente transferido para outra associação similar à dissolvida (artigo 61); 4) não há regras para organização do empreendimento, especialmente quanto ao procedimento deliberativo, administração e assunção de riscos; 5) não há previsão de aplicação subsidiária da disciplina jurídica das sociedades às associações (artigo 44, $\S 2^{\circ}{ }^{134}$ ), com exceção das regras sobre liquidação, no que couber (artigo 51, § $2^{\text {o135}}$ ). Estas características das associações dificultam a limitação dos riscos do negócio de venture capital, sendo incompatíveis com sua estrutura negocial ${ }^{136}$.

Consequentemente, restam as sociedades como tipos aptos a organizar negócios de venture capital. A sociedade é acordo no qual há definição de um fim comum, contribuição dos sócios, assunção de riscos e partilha de resultados. Sua constituição produz efeitos imediatos, independentemente da aquisição de personalidade jurídica, que ocorre com o registro do instrumento de contrato no órgão competente. O Código Civil determina que sociedades tenham por objeto a atividade econômica e visem à partilha dos resultados entre os sócios (artigos 966 e 981).

A legislação atual adota tipologia societária fechada e, consequentemente, há proibição de criação de formas atípicas ou tipos mistos. A inscrição obrigatória da sociedade (artigos 968 e 985) obedece às regras definidas nos artigos 1.150 e 1.153 do

\footnotetext{
${ }^{133}$ Código Civil, artigo 57. A exclusão do associado só é admissível havendo justa causa, assim reconhecida em procedimento que assegure direito de defesa e de recurso, nos termos previstos no estatuto.

${ }^{134}$ Código Civil, artigo $44, \S 2^{\circ}$. As disposições concernentes às associações aplicam-se subsidiariamente às sociedades que são objeto do Livro II da Parte Especial deste Código.

${ }^{135}$ Código Civil, artigo 51, $\S 2^{\circ}$. As disposições para a liquidação das sociedades aplicam-se, no que couber, às demais pessoas jurídicas de direito privado.

${ }^{136}$ COOTER e SCHÄFER explicam que negócios inovadores exigem a superação de duplo dilema de confiança: o medo dos investidores em perder seu capital, e o medo dos empreendedores em terem suas ideias divulgadas ao público sem seu consentimento. Segundo os autores, a solução está na adoção do modelo societário, que se tornou a forma dominante para proteger segredos industriais, porque o empreendedor tem mais a ganhar com sua parcela dos lucros futuros do que se tentar se apropriar indevidamente dos recursos do investidor. Este, por sua vez, tem mais a ganhar com a preservação dos segredos da companhia (ideia inovadora) do que com a disseminação da ideia. A diferença entre essa forma de organização e outras, como a associação, é que a primeira é forma de propriedade em si mesma e, portanto, pode ser negociada no mercado, ao passo que a segunda não é negociável, por não ser uma propriedade em si mesma. (COOTER, Robert D.; SCHAEFER, Hans B. The secret of growth is financing secrets: corporate law and growth economics. Journal of Law and Economics 54 (2011): S105-S123. Disponível em: <http://works.bepress.com/robert_cooter/166/>. Acesso em: 23.02.2013).
} 
Código Civil e na legislação especial ${ }^{137}$, que exi gem a verificação formal e material dos atos constitutivos de sociedade como condição prévia para a obtenção da inscrição, devendo haver plena adequação do contrato às regras estabelecidas para o tipo ${ }^{138}$.

Na vigência do antigo Código Civil de 1.916, as normas contidas nos artigos 1.363 e $1.364^{139}$ permitiam formas atípicas de sociedade. $\mathrm{O}$ artigo 1.363 indicava que celebravam contrato de sociedade as pessoas que, mutuamente, se obrigassem a combinar esforços ou recursos, para lograr fins comuns. Bastava, portanto, a combinação de esforços ou bens e a busca de finalidade comum. O artigo 1.364 determinava que as sociedades que se revestissem da forma estabelecida deveriam obedecer a seus preceitos, naquilo que não contrariassem o Código Civil. Assim, outras formas de organização poderiam ser enquadradas como sociedades, como, por exemplo, o consórcio de sociedades. Tais normas não foram reproduzidas pelo atual Código Civil de 2.002, obrigando os negócios a adotar tipo predefinido em lei ${ }^{140}$.

O exemplo do consórcio é esclarecedor. Os artigos 278 e 279 da Lei das S/A, que entrou em vigor no ano de 1.976 e, portanto, na vigência do antigo Código Civil, definem um tipo contratual de natureza convencional usado para associação entre sociedades preexistentes e que não cria pessoa jurídica nova. Para o Código Civil de 1.916, o consórcio poderia ser entendido como sociedade, situação que não se repete no

\footnotetext{
${ }^{137}$ Lei n. 8.934/94 (Lei de Registros Públicos Mercantis): Art. 35. Não podem ser arquivados: I - os documentos que não obedecerem às prescrições legais ou regulamentares ou que contiverem matéria contrária aos bons costumes ou à ordem pública, bem como os que colidirem com o respectivo estatuto ou contrato não modificado anteriormente; (...).

Art. 40. Todo ato, documento ou instrumento apresentado a arqui vamento será objeto de exame do cumprimento das formalidades legais pela junta comercial. § $1^{\circ}$ Verificada a existência de vício insanável, o requerimento será indeferido; quando for sanável, o processo será colocado em exigência. (...).

Lei n. 6.015/73: Art. 114. No Registro Civil de Pessoas Jurídicas serão inscritos: I - os contratos, os atos constitutivos, o estatuto ou compromissos das sociedades civis, religiosas, pias, morais, científicas ou literárias, bem como o das fundações e das associações de utilidade pública; II - as sociedades civis que revestirem as formas estabelecidas nas leis comerciais, salvo as anônimas.

${ }^{138}$ SZTAJN, Rachel. A disciplina das sociedades no código civil brasileiro. In: Princípios do novo Código Civil Brasileiro e outros temas - homenagem a Tullio Ascarelli. JUNQUEIRA DE AZEVEDO, Antonio; TORRES. Heleno T.; CARBONE, Paolo (org.). $2^{\mathrm{a}}$ Ed., São Paulo: Quartier Latin, 2010, pp. 576; 583-584; 590 .

${ }^{139}$ Código Civil de 1.916 (Decreto n. 3.071/16), Artigo 1.363. "Celebram contrato de sociedade as pessoas que mutuamente se obrigam a combinar seus esforços ou recursos, para lograr fins comuns".

Artigo 1.364. Quando as sociedades civis revestirem as formas estabelecidas nas leis comerciais, entre as quais se inclui a das sociedades anônimas, obedecerão aos respectivos prec eitos, no em que não contrariem os deste Código; mas serão inscritas no registro civil, e será civil o seu foro.

${ }_{140}$ Argumentos apresentados por: SZTAJN, Rachel. Associações e sociedades. Revista de Direito Mercantil, Industrial, Econômico e Financeiro, Ano XLI, n. 128, Out./Dez. 2002, pp. 22-23.
} 
atual Código Civil. GUERREIRO esclarece que o Código atual não trata do consórcio e que este não pode ser equiparado às sociedades porque há proibição de criação de tipos novos ${ }^{141}$ e a doutrina e a jurisprudência nem sempre distinguem com nitidez o consórcio da sociedade não personificada ${ }^{142,143,144}$. A possibilidade de recurso à disciplina societária para interpretar os consórcios poderia facilitar a distinção.

Em muitas situações, o negócio de venture capital pode se conformar à estrutura de um contrato "típico", isto é, um modelo predisposto na legislação, com possibilidade de as partes definirem as cláusulas específicas do negócio ${ }^{145}$. Isso ocorre quando o conteúdo do negócio é inovador, mas não a forma de conduzi-lo.

Em outras situações, formas atípicas e tipos mistos são usados para enquadramento de situações nas quais são requeridas novas formas de organização da atividade e repartição de riscos e retorno entre os participantes, condições que também podem ser encontradas em projetos de venture capital. Nestes casos, o suporte

${ }^{141}$ GUERREIRO, José A. T. Regime jurídico do consórcio. Revista de Direito Mercantil Industrial Econômico e Financeiro, São Paulo, Ano XLIV, v. 138, Abr./Jun. 2005, pp. 202-203.

${ }^{142} \mathrm{Na}$ exposição justificativa do projeto que instituiu a Lei das S/A, LAMY FILHO e BULHÕES PEDREIRA esclarecem que a Lei “(...) regula o consórcio, como modalidade de sociedade não personificada que tem por objeto a execução de determinado empreendimento". (grifos nossos) (LAMY FILHO, Alfredo; BULHÕES PEDREIRA, José L., A lei das S/A: (pressupostos, elaboração, aplicação). Rio de Janeiro: Renovar, 1992, p. 251).

${ }^{143}$ TJ-SP, Agr. Reg. n. 0026018-44.2012.8.26.0000/50000, Comarca de Bauru, Agravantes: Mondelli Indústria de Alimentos S/A, Antonio Mondelli, Constantino Mondelli, José Mondelli, Braz Mondelli e Rosana Aparecida Acçolini Dalla Coletta. Agravado: Hapi Comércio Alimentícios Ltda. Registro: 2012.0000247594: “(...) empresa que sustenta manter com a agravada pessoa jurídica uma sociedade em conta de participação a ser convertida em 'joint venture' ou outro tipo societário" (...) "a documentação já apresentada dá o necessário respaldo probatório à alegação da autora no sentido de que, a partir de 'Memorando de Entendimentos', elaborado com vistas à constituição de uma 'sociedade em conta de participação' (...)". (grifos nossos).

${ }^{44}$ Por exemplo: TJ-SP, 5 a Câmara de Direito Privado do Tribunal de Justiça de São Paulo. Agr. Instr. ${ }^{\circ}$ 994.09.274268-5, Comarca de São Paulo. Agravante: Caloi Fitness Ltda. Agravados: Kiko's Fitness Store Comercial Ltda. E Gymbrands Equipamentos de Ginástica Ltda.; Voto n. 18.128. Data: 19.05.2010: "Antecipação de Tutela - Ação de dissolução de sociedade e contrato de parceria - Pedido formulado no sentido de pronta dissolução da empresa objeto do contrato de joint venture - Indeferimento em primeiro grau - Verossimilhança caracterizada - Art. 273 do Código de Processo Civil - Recurso provido para conceder a tutela antecipada para o fim de determinar a prévia dissolução da empresa Gymbrands.”. TJ-SP, Agravo Instr. N. 994.09.274268-5 (686.752-4/0-00) Comarca: São Paulo Agravante: Caloi Fitness Ltda. Agravados: Kiko's Fitness Store Comercial Ltda. e Outra. Voto N. 18128: Ementa: Antecipação de Tutela Ação de dissolução de sociedade e contrato de parceria - Pedido formulado no sentido de pronta dissolução da sociedade objeto do contrato de joint venture - Indeferimento em primeiro grau - Verossimilhança caracterizada - Art. 273 do Código de Processo Civil - Recurso provido para conceder a tutela antecipada para o fim de determinar a prévia dissolução da empresa Gymbrands. (grifos nossos).

${ }_{145}$ Conceito de contrato típico apresentado por: SZTAJN, Rachel. Futuros e swaps - uma visão jurídica. São Paulo: Cultural Paulista, 1999, pp. 51-52;210. 
normativo predisposto na legislação pode ser inadequado para organizar o negócio e a obrigatoriedade de haver enquadramento a um tipo contratual predisposto na legislação aumenta os riscos do negócio e a insegurança jurídica para os sócios e terceiros que contratem com a sociedade. $\mathrm{O}$ aumento dos riscos pode inviabilizar o empreendimento e, consequentemente, o desenvolvimento de inovações.

A impossibilidade de recurso às formas atípicas ou mistas implica na obrigatoriedade de regular em contrato todas as matérias não tratadas pelo tipo escolhido, mas necessárias ao desenvolvimento do empreendimento. Neste caso, pode haver incompatibilidade entre o tipo e as cláusulas contratuais introduzidas pelas partes.

A tipologia societária fechada restringe a "criatividade" empresarial, uma tradição do Direito Comercial, pois os desafios da inovação requerem a busca de novas formas de organização da cooperação entre as partes. Se a tipologia fechada fosse solução adotada em épocas passadas, não existiria a sociedade anônima como a conhecemos, e projetos dotados de alto grau de incerteza seriam inviabilizados ou dificultados pela ausência de estrutura contratual adequada ${ }^{146}$.

A questão permanece sem solução nas propostas legislativas que pretendem regular o direito societário ${ }^{147}$.

A tipologia fechada obriga a que empreendimentos de venture capital se adaptem a algum dos tipos encontrados no Livro II do Código Civil ou na Lei das Sociedades Anônimas, porém os tipos ali indicados não são adequados à limitação dos riscos do negócio.

A estrutura das sociedades de pessoas é de difícil utilização, pois, como ensina

\footnotetext{
${ }^{146}$ MELLO FRANCO e SZTAJN apresentam a origem e evolução das sociedades anônimas, indicando que sua estrutura e função surgiram da prática mercantil, e, à época, eram desconhecidas do sistema jurídico vigente. As companhias surgiram para viabilizar empreendimentos inovadores e de alto risco de insucesso, que era diluído entre os participantes do empreendimento. (MELLO FRANCO, Vera H.; SZTAJN, Rachel. Direito empresarial II. $2^{\text {a }}$ Ed., São Paulo: Revista dos Tribunais, 2009, pp. 21-34).

${ }^{147}$ Projeto de Lei n. 1.572/11, de autoria do deputado Vicente Cândido: "Artigo 122. A sociedade empresária pode adotar os seguintes tipos: I - sociedade anônima; II - sociedade limitada; III - sociedade em nome coletivo; IV - sociedade em comandita simples; e V - sociedade em comandita por ações". (Disponível em: <www.camara.go v.br>. Acesso em: 28.11.2013).
} 
MELLO FRANCO, estes tipos legais implicam em responsabilidade solidária dos sócios $^{148}$. Consequentemente, são inadequadas as sociedades em comum (artigo 986) ${ }^{149}$, em nome coletivo (artigo 1.039), em comandita simples (artigo 1.045) e em conta de participação (artigo 991), previstas no Código Civil. Nestes tipos, a existência de responsabilidade solidária não é adequada para lidar com o alto grau de incerteza presente em negócios de venture capital, pois aumenta os riscos assumidos pelos sócios.

No caso da sociedade em conta de participação, por ser não personificada, o exercício da atividade restringe-se ao sócio ostensivo (empreendedor), que atua em nome próprio, sendo que o sócio oculto (investidor) apenas fornece os recursos e participa dos resultados. O investidor que contratar com terceiros responderá solidariamente pelas obrigações assumidas, conforme determinação dos artigos 991 e 993 do Código Civil ${ }^{150}$, situação por ele indesejada. Entretanto, negócios de venture capital requerem que o investidor desempenhe atividades em nome da sociedade, havendo necessidade de estabelecimento de relações com terceiros para a prestação de garantias e a negociação com clientes e fornecedores da sociedade.

As empresas individuais de responsabilidade limitada (artigo 980-A ${ }^{151}$ )

\footnotetext{
${ }^{148}$ MELLO FRANCO, Vera H. As sociedades de pessoas na atualidade. Uma visão comparativa crítica. Revista de Direito Mercantil, Industrial, Econômico e Financeiro, Ano L, n. 157, Jan./Mar. 2011, p. 110.

${ }^{149}$ Em relação a estas, MARCONDES MACHADO entende que produzem relações societárias, pois há contribuição dos sócios, obrigação de partilha dos resultados e possibilidade de operar com terceiros, independentemente de inscrição. Por isso, entende que o Código Civil não acolheu a sociedade irregular, ou de fato, prevista no artigo 304 do revogado Código Comercial. (MARCONDES MACHADO, Sylvio. Questões de direito mercantil. São Paulo: Saraiva, 1977, p. 16).

${ }_{150}$ Código Civil, artigo 991. Na sociedade em conta de participação, a atividade constitutiva do objeto social é exercida unicamente pelo sócio ostensivo, em seu nome individual e sob sua própria e exclusiva responsabilidade, participando os demais dos resultados correspondentes. Parágrafo único. Obriga-se perante terceiro tão somente o sócio ostensivo; e, exclusivamente perante este, o sócio participante, nos termos do contrato social.

Artigo 993. O contrato social produz efeito somente entre os sócios, e a eventual inscrição de seu instrumento em qualquer registro não confere personalidade jurídica à sociedade. Parágrafo único. Sem prejuízo do direito de fiscalizar a gestão dos negócios sociais, o sócio participante não pode tomar parte nas relações do sócio ostensivo com terceiros, sob pena de responder solidariamente com este pelas obrigações em que intervier.

${ }^{151}$ Código Civil, artigo 980-A. A empresa individual de responsabilidade limitada será constituída por uma única pessoa titular da totalidade do capital social, devidamente integralizado, que não será inferior a 100 (cem) vezes o maior salário-mínimo vigente no País. $§ 1^{\circ} \mathrm{O}$ nome empresarial deverá ser formado pela inclusão da expressão "EIRELI" após a firma ou a denominação social da empresa individual de responsabilidade limitada. $\S 2^{\circ}$ A pessoa natural que constituir empresa individual de responsabilidade limitada somente poderá figurar em uma única empresa dessa modalidade. $\S 3^{\circ} \mathrm{A}$ empresa individual de responsabilidade limitada também poderá resultar da concentração das quotas de outra modalidade societária num único sócio, independentemente das razões que motivaram tal concentração. $\S 5^{\circ}$ Poderá ser atribuída à
} 
apresentam as mesmas desvantagens das sociedades de pessoas, além do requisito da unipessoalidade, que inviabiliza sua utilização em negócios de venture capital, que demandam a associação obrigatória de dois ou mais agentes econômicos.

De acordo com o artigo 982 do Código Civil, considera-se empresária a sociedade que tem por objeto o exercício de atividade própria de empresário, que é o caso de negócios de venture capital. Por isso, a sociedade simples (artigo 997), por não ser empresária, também deve ser afastada.

Também inaplicável o tipo da sociedade cooperativa (artigo 1.093), sociedade civil por natureza, equiparada por lei às sociedades simples ${ }^{152}$.

A sociedade em comandita por ações, disciplinada pela lei acionária ${ }^{153}$, também é inadequada, devido à exigência de responsabilidade ilimitada do acionista-diretor ${ }^{154}$.

\section{Com base nos artigos 1.039 e 1.045 do Código Civil ${ }^{155}$, MELLO FRANCO} entende haver proibição de participação de sociedades de pessoas em sociedades de capitais, assim como impedimento à estruturação de grupos societários formados por sociedades de pessoas ${ }^{156}$. A proibição impede a constituição de sociedades mais sofisticadas, combinando os tipos contratuais.

empresa individual de responsabilidade limitada constituída para a prestação de serviços de qualquer natureza a remuneração decorrente da cessão de direitos patrimoniais de autor ou de imagem, nome, marca ou voz de que seja detentor o titular da pessoa jurídica, vinculados à atividade profissional. $\S 6^{\circ}$ Aplicam-se à empresa individual de responsabilidade limitada, no que couber, as regras previstas para as sociedades limitadas.

${ }^{152}$ Código Civil, artigo 982. Salvo as exceções expressas, considera-se empresária a sociedade que tem por objeto o exercício de atividade própria de empresário sujeito ao registro (art. 967); e, simples, as demais. Parágrafo único. Independentemente de seu objeto, considera-se empresária a sociedade por ações; e, simples, a cooperativa.

${ }^{153}$ Lei n. 6.404/76, artigos 280 a 284.

${ }^{154}$ Código Civil, artigo 1.091. Somente o acionista tem qualidade para administrar a sociedade e, como diretor, responde subsidiária e ilimitadamente pelas obrigações da sociedade. $\S 1^{\circ}$ Se houver mais de um diretor, serão solidariamente responsáveis, depois de esgotados os bens sociais.

${ }^{155}$ Código Civil, artigo 1.039. Somente pessoas físicas podem tomar parte na sociedade em nome coletivo, respondendo todos os sócios, solidária e ilimitadamente, pelas obrigações sociais.

Artigo 1.045. Na sociedade em comandita simples tomam parte sócios de duas categorias: os comanditados, pessoas físicas, responsáveis solidária e ilimitadamente pelas obrigações sociais; e os comanditários, obrigados somente pelo valor de sua quota.

${ }^{156}$ MELLO FRANCO, Vera H. As sociedades de pessoas na atualidade. Uma visão comparativa crítica. Revista de Direito Mercantil, Industrial, Econômico e Financeiro, Ano L, n. 157, Jan./Mar. 2011, p. 110. 
A sociedade anônima (companhia) aberta também não pode ser usada para organizar negócios de venture capital. $\mathrm{O}$ artigo $4^{\circ}$ da Lei das S/A a define como a sociedade cujos valores mobiliários de sua emissão são negociados em bolsa de valores ou mercado organizado.

Negócios de venture capital apresentam alto grau de riscos, que poderiam ser distribuídos entre os diversos participantes do mercado por meio da constituição de companhia aberta e realização de oferta de ações em bolsa de valores. Entretanto, essa possibilidade é reduzida, porque o artigo 82 da lei acionária determina que a companhia apresente pedido de registro contendo, à parte do projeto do estatuto social, o estudo de viabilidade econômica e financeira do empreendimento e o prospecto ${ }^{157}$.A elaboração de estudo é de difícil realização em negócios de venture capital, porque não há bases sólidas para a avaliação da viabilidade de desenvolvimento das atividades, mas o prospecto da companhia (artigo $84^{158}$ ) deve especificar os motivos que justifiquem a expectativa de bom êxito do empreendimento, incluindo a análise detalhada dos riscos do negócio, de difícil mensuração nesses projetos. Mesmo que os fundadores de venture capital decidam adotar o tipo contratual das companhias abertas, os interessados na subscrição de ações, que são agentes econômicos bem informados, irão avaliar os riscos do negócio, resultando em desinteresse pela aquisição das ações ou redução do preço pago, inviabilizando a oferta. Ainda, a operação de oferta pública de ações é atividade complexa e consome recursos significativos, sendo desproporcional à estrutura e porte apresentados por negócios de venture capital.

Pelas razões expostas, todos os tipos legais mencionados devem ser descartados, porque inadequados para organizar negócios de venture capital, restando a possibilidade de adoção dos tipos das sociedades limitadas e anônimas fechadas.

\footnotetext{
${ }^{157}$ Lei n. 6.404/76, Artigo 82. A constituição de companhia por subscrição pública depende do prévio registro da emissão na Comissão de Valores Mobiliários, e a subscrição somente poderá ser efetuada com a intermediação de instituição financeira. $\S 1^{\circ} \mathrm{O}$ pedido de registro de emissão obedecerá às normas expedidas pela Comissão de Valores Mobiliários e será instruído com: a) o estudo de viabilidade econômica e financeira do empreendimento; b) o projeto do estatuto social; c) o prospecto, organizado e assinado pelos fundadores e pela instituição financeira intermediária. § $2^{\circ}$ A Comissão de Valores Mobiliários poderá condicionar o registro a modificações no estatuto ou no prospecto e denegá-lo por inviabilidade ou temeridade do empreendimento, ou inidoneidade dos fundadores.

${ }^{158}$ Lei n. 6.404/76, Artigo 84. O prospecto deverá mencionar, com precisão e clareza, as base s da companhia e os motivos que justifiquem a expectativa de bom êxito do empreendimento.
} 


\section{III.4. Tipos avaliados: sociedade anônima fechada e limitada}

O artigo $4^{\circ}$ da Lei das S/A define sociedade anônima (companhia) fechada como aquela cujos valores mobiliários de sua emissão são negociados de forma privada, sem intermediação de bolsa de valores ou de mercados organizados. Trata-se de sociedade de capitais dotada de personalidade jurídica própria, distinta da dos sócios, e patrimônio autônomo.

De acordo com os artigos 1.052 a 1.055, do Código Civil, a sociedade limitada possui personalidade jurídica e capital social dividido em cotas, que são negociadas de forma privada e sem intermediação. Funciona como um centro de imputação autônomo, contratando com terceiros em nome próprio e respondendo pelas obrigações com seus bens, que são distintos daqueles pertencentes aos sócios.

Nos estudos de caso realizados, a maioria dos entrevistados indicou que costuma exigir a transformação de sociedades limitadas em anônimas como condição para viabilização do investimento em projetos de venture capital. Isso porque as limitadas apresentam regras mais rígidas e complexas que as aplicáveis às sociedades anônimas ${ }^{159}$. Há diversos dispositivos legais incapazes de limitação suficiente dos riscos de negócios de venture capital.

\section{III.4.1. Principais categorias de riscos avaliados}

Organizamos os principais riscos nas seguintes categorias: contratação do negócio; alocação do poder de decisão; interrupção do negócio.

Os riscos de contratação do negócio referem-se aos entraves na negociação das operações que inviabilizam o investimento inicial. Subdividem-se em:

1) Contribuição dos sócios: forma de estabelecimento e valor da

\footnotetext{
${ }^{159}$ Nesse sentido: MELLO FRANCO, Vera H. O triste fim das sociedades limitadas no novo Código Civil. Revista de Direito Mercantil, Industrial, Econômico e Financeiro, Ano XL, n. 123, pp. 81-85, Jul./Set. 2001.
} 
contribuição para o capital social, pessoal ou patrimonial ${ }^{160}$, e implicações em caso de descumprimento;

2) Integralização da contribuição: não integralização, pelos sócios, da participação subscrita, com prejuízos à operacionalização do negócio, ou sua inviabilização, se em andamento;

3) Limitação da responsabilidade: existência de responsabilidade excessiva, reduzindo o interesse pela contratação do negócio.

Os riscos de alocação do poder de decisão referem-se à distribuição de poder na sociedade, e seus efeitos sobre a estabilidade do negócio. Subdividem-se em:

1) Quoruns deliberativos: riscos de imprevisibilidade do resultado das deliberações sociais, derivados dos quoruns aplicáveis;

2) Alinhamento prévio de interesses: risco de imobilização da sociedade, decorrente da impossibilidade de haver alinhamento prévio de interesses entre os sócios, levando à necessidade de renegociação entre as partes durante a execução do projeto;

3) Limitação do direito de voto: riscos de inviabilização do procedimento deliberativo, com aumento da incerteza sobre as variáveis de decisão, em função da impossibilidade de limitação do direito de voto sobre determinadas matérias críticas para o negócio;

4) Invalidação de deliberações sociais: riscos de instabilidade derivados da possibilidade, ou não, de desfazimento dos efeitos alcançados

\footnotetext{
${ }^{160}$ A posição jurídica dos sócios reúne os elementos de capital e trabalho, podendo ser determinada pelas duas espécies de contribuição que constituem a causa de sua obrigação, a saber, a contribuição patrimonial e a pessoal. A contribuição patrimonial pode ser limitada ou ilimitada, sendo que a primeira pode ser representada por cotas ou ações. A contribuição pessoal do sócio pode ser máxima ou mínima, variando em extensão e intensidade. A contribuição máxima refere-se à plena administração da sociedade e a mínima coincide com a simples fiscalização dos negócios sociais. (MARCONDES MACHADO, Sylvio. Questões de direito mercantil. São Paulo: Max Limonad, 1970, pp. 176-177).
} 
pelas deliberações sociais e do tempo decorrido entre a deliberação e sua posterior invalidação.

Os riscos de interrupção do ne gócio referem-se a situações que podem implicar na descontinuidade das atividades, com encerramento prematuro do projeto. Subdividem-se em:

1) Custos excessivos de operação: riscos decorrentes da existência de custos de operação do negócio, em especial os relativos à realização de deliberações sociais, publicação de informações e os derivados de obrigações tributárias, trabalhistas e previdenciárias;

2) Dissociação: riscos de descontinuidade do projeto devido ao desligamento de sócio que se obrigou a realizar prestações essenciais ao negócio;

3) Dissolução: risco de perda total dos recursos investidos devido à impossibilidade de alcançar, quando necessário, a extinção e liquidação da sociedade.

\section{III.4.2. Riscos de contratação}

\section{III.4.2.1. Contribuição dos sócios}

\section{Definição do risco}

A contribuição dos sócios denota o grau de participação no empreendimento e o papel desempenhado no desenvolvimento das atividades, a proporção de distribuição dos riscos entre os contratantes e a partilha dos resultados.

O empreendedor de venture capital contribui, em geral, com serviços, isto é, conhecimento a respeito da forma de desenvolvimento da ideia inovadora, e o investidor contribui com dinheiro ou bens. Estes são de mais fácil mensuração, ao 
passo que a contribuição em serviços exige esforço adicional de avaliação, podendo haver maior risco de erro de estimativa.

Pode haver desalinhamento entre a contribuição do empreendedor e do investidor de negócios de venture capital, resultando em aumento dos riscos e redução do retorno para o sócio que tenha sido prejudicado pelo cálculo inadequado. Tal situação pode beneficiar o empreendedor ou o investidor, conforme, respectivamente, a contribuição em serviços tenha sido superavaliada ou subavaliada.

No caso de contribuição em bens, é necessário haver responsabilização do sócio pela exata estimação dos bens conferidos ao capital, visando a evitar diferença entre a contribuição efetivamente realizada e a proporção da participação no negócio. A responsabilização também garante maior proteção aos credores, uma vez que os bens servem de garantia às operações contratadas com terceiros.

\section{$\underline{\text { Formas de limitação do risco }}$}

De acordo com o parágrafo $2^{\circ}$ do artigo 1.055 do Código Civil ${ }^{161}$, na sociedade limitada é permitida a contribuição em bens ou dinheiro, mas a contribuição em serviços é proibida. Desta forma impede-se o cálculo do valor da participação do empreendedor, porque este, normalmente, somente aporta conhecimento à sociedade. Trata-se de risco não diversificável em negócios de venture capital, porque não há maneira de contornar a proibição legal. Em consequência, há aumento do risco de inviabilizar a definição do valor de sua contribuição para o negócio, tornando sem efeito a constituição da sociedade. A viabilização do projeto dependerá de negociação entre os sócios para definir forma alternativa de cálculo do valor das cotas do empreendedor, a ser integralizada, necessariamente, em bens ou dinheiro, que terão que ser obtidos de outras fontes ou emprestados pelo investidor.

Para as sociedades anônimas, o artigo $7^{\circ}$ da lei acionária ${ }^{162}$ autoriza a

\footnotetext{
${ }^{161}$ Código Civil, artigo 1.055, § $2^{\circ}$. É vedada contribuição que consista em prestação de serviços.

${ }^{162}$ Lei n. $6.404 / 76$, artigo $7^{\circ}$. O capital social poderá ser formado com contribuições em dinheiro ou em qualquer espécie de bens suscetíveis de avaliação em dinheiro.
} 
contribuição, desde que os serviços sejam suscetíveis de avaliação monetária, podendose aplicar os critérios indicados no artigo $8^{\mathbf{0} 163}$. Pode haver dificuldades para avaliação, porque a lei determina que se faça a estimativa por perito ou empresa especializada, apresentando-se laudo fundamentado e indicação dos critérios e dos elementos de comparação adotados. Como os serviços objeto da avaliação são desconhecidos do mercado porque o negócio de venture capital é inovador, pode não haver referências suficientes para a estimativa.

Por isso, há possibilidade de haver subavaliação ou superavaliação da prestação nas anônimas, casos em que deve ser possível a reavaliação a pedido do investidor. Os $\operatorname{artigos} 4^{\circ}$ e $4^{\circ}$-A da lei acionária ${ }^{164}$ fornecem a base conceitual para a revisão, desde

${ }^{163}$ Lei n. 6.404/76, artigo $8^{\circ}$. A avaliação dos bens será feita por 3 (três) peritos ou por empresa especializada, nomeados em assembleia-geral dos subscritores, convocada pela imprensa e presidida por um dos fundadores, instalando-se em primeira convocação com a presença de subscritores que representem metade, pelo menos, do capital social, e em segunda convocação com qualquer número. § $1^{\circ}$ Os peritos ou a empresa avaliadora deverão apresentar laudo fundamentado, com a indicação dos critérios de avaliação e dos elementos de comparação adotados e instruído com os documentos relativos aos bens avaliados, e estarão presentes à assembleia que conhecer do laudo, a fim de prestarem as informações que lhes forem solicitadas. $\S 2^{\circ}$ Se o subscritor aceitar o valor aprovado pela assembleia, os bens incorporar-se-ão ao patrimônio da companhia, competindo aos primeiros diretores cumprir as formalidades necessárias à respectiva transmissão. $\S 3^{\circ}$ Se a assembleia não aprovar a avaliação, ou o subscritor não aceitar a avaliação aprovada, ficará sem efeito o projeto de constituição da companhia. $\S 4^{\circ}$ Os bens não poderão ser incorporados ao patrimônio da companhia por valor acima do que lhes tiver dado o subscritor. § $5^{\circ}$ Aplica-se à assembleia referida neste artigo o disposto nos $\S \S 1^{\circ} \mathrm{e} 2^{\circ}$ do artigo $115 . \S 6^{\circ}$ Os avaliadores e o subscritor responderão perante a companhia, os acionistas e terceiros, pelos danos que lhes causarem por culpa ou dolo na avaliação dos bens, sem prejuízo da responsabilidade penal em que tenham incorrido; no caso de bens em condomínio, a responsabilidade dos subscritores é solidária.

${ }^{164}$ Lei n. 6.404/76, artigo $4^{\circ}$ (...) $\S 4^{\circ}$. O registro de companhia aberta para negociação de ações no mercado somente poderá ser cancelado se a companhia emissora de ações, o acionista controlador ou a sociedade que a controle, direta ou indiretamente, formular oferta pública para adquirir a totalidade das ações em circulação no mercado, por preço justo, ao menos igual ao valor de avaliação da companhia, apurado com base nos critérios, adotados de forma isolada ou combinada, de patrimônio líquido contábil, de patrimônio líquido avaliado a preço de mercado, de fluxo de caixa descontado, de comparação por múltiplos, de cotação das ações no mercado de valores mobiliários, ou com base em outro critério aceito pela Comissão de Valores Mobiliários, assegurada a revisão do valor da oferta, em conformidade com o disposto no art. $4^{\circ}$-A. (...). (grifo nossos).

Artigo $4^{\circ}$-A. Na companhia aberta, os titulares de, no mínimo, $10 \%$ (dez por cento) das ações em circulação no mercado poderão requerer aos administradores da companhia que convoquem assembleia especial dos acionistas titulares de ações em circulação no mercado, para deliberar sobre a realização de nova avaliação pelo mesmo ou por outro critério, para efeito de determinação do valor de avaliação da companhia, referido no $\S 4^{\circ}$ do art. $4^{\circ} . \S 1^{\circ} \mathrm{O}$ requerimento deverá ser apresentado no prazo de 15 (quinze) dias da divulgação do valor da oferta pública, devidamente fundamentado e acompanhado de elementos de convicção que demonstrem a falha ou imprecisão no emprego da metodologia de cálculo ou no critério de avaliação adotado, podendo os acionistas referidos no caput convocar a assembleia quando os administradores não atenderem, no prazo de 8 (oito) dias, ao pedido de convocação. $\S 2^{\circ}$ Consideram-se ações em circulação no mercado todas as ações do capital da companhia aberta menos as de propriedade do acionista controlador, de diretores, de conselheiros de administração e as em tesouraria. $\$ 3^{\circ}$ Os acionistas que requererem a realização de nova avaliação e aqueles que votarem a seu favor deverão ressarcir a companhia pelos custos incorridos, caso o novo valor seja inferior ou igual ao valor inicial da oferta pública. $\S^{\circ}$ Caberá à Comissão de Valores 
que previstos no estatuto social e adaptados para a situação descrita. Isto poderia funcionar da seguinte maneira: em caso de divergência quanto à avaliação da contribuição, seria facultado aos sócios descontentes requerer novo cálculo, porém se este resultar em valor menor ou igual ao original, o requerente fica obrigado a reembolsar os gastos com o procedimento revisional. $\mathrm{O}$ fundamento da norma encontra-se na internalização dos custos de revisão, ou seja, aquele que, de forma oportunista, solicita recálculo indevido suporta os custos, e aquele que realiza avaliação inadequada da contribuição fica sujeito à possibilidade de revisão. A solução permite limitar, ainda que parcialmente, o risco de erro de avaliação, mas não o elimina.

Nas limitadas, o $\$ 1^{\circ}$ do artigo 1.055 do Código Civil determina haver solidariedade dos sócios quanto à exata estimação dos bens conferidos ao capital social, pelo prazo de cinco anos contados a partir da data do registro da sociedade. A medida visa a proteger a sociedade e os credores, porém aumenta a responsabilidade dos sócios não faltosos, sendo indesejado por estes porque amplia os riscos individuais. No negócio de venture capital há apenas dois sócios, logo o inadimplemento do empreendedor amplia a responsabilidade do investidor para a totalidade do capital necessário. $\mathrm{O}$ inadimplemento do investidor inviabiliza o projeto, porque o empreendedor não dispõe de recursos para aportar ao negócio.

Nas companhias não há solidariedade entre os acionistas pela integralização do capital social. O artigo 106 da lei acionária ${ }^{165}$ determina a obrigatoriedade de realização do capital social e a responsabilização individual pela integralização e exata estimação dos bens conferidos ao capital.

\section{$\underline{\text { Avaliação do risco }}$}

\footnotetext{
Mobiliários disciplinar o disposto no art. $4^{\circ}$ e neste artigo, e fixar prazos para a eficácia desta revisão. (grifos nossos).

${ }^{165}$ Lei n. 6.404/76, art. 106. O acionista é obrigado a realizar, nas condições previstas no estatuto ou no boletim de subscrição, a prestação correspondente às ações subscritas ou adquiridas. $\S 1^{\circ}$ Se o estatuto e o boletim forem omissos quanto ao montante da prestação e ao prazo ou data do pagamento, caberá aos órgãos da administração efetuar chamada, mediante avisos publicados na imprensa, por 3 (três) vezes, no mínimo, fixando prazo, não inferior a 30 (trinta) dias, para o pagamento. $\S 2^{\circ} \mathrm{O}$ acionista que não fizer o pagamento nas condições previstas no estatuto ou boletim, ou na chamada, ficará de pleno direito constituído em mora, sujeitando-se ao pagamento dos juros, da correção monetária e da multa que o estatuto determinar, esta não superior a $10 \%$ (dez por cento) do valor da prestação.
} 
Grau de limi tação do risco:

- Na sociedade limitada: Baixo.

- $\quad$ Na sociedade anônima: Médio.

\section{III.4.2.2. Integralização da cont ribuição}

\section{Definição do risco}

Como pode haver significativo intervalo de tempo entre o momento do estabelecimento da contribuição dos sócios para o capital da sociedade e sua integralização, o sócio pode reavaliar sua posição na sociedade e os riscos assumidos. Se considerar os riscos excessivos, pode adotar comportamento oportunista no sentido de não integralizar a contribuição. Como o negócio de venture capital depende da intrínseca colaboração entre o empreendedor e o investidor e dos recursos conferidos ao capital da sociedade, a não integralização inviabiliza o projeto.

Se o investidor não realiza a integralização inviabiliza-se a sociedade que não pode iniciar as atividades sem os recursos. Se a integralização for parcial, a redução de capital social pode ampliar o risco de continuidade das operações, porque haverá carência de recursos para desenvolver as atividades. Se houver mais de um investidor e apenas um deles for remisso, há possibilidade de o negócio prosseguir com os sócios remanescentes, desde que seja suprido o capital requerido.

Se o empreendedor não integralizar a contribuição, haverá inviabilidade do projeto, pois sua prestação é personalíssima e as atividades não podem ser desenvolvidas sem seu conhecimento a respeito da ideia inovadora.

\section{$\underline{\text { Formas de limitação do risco }}$}

O Código Civil e a lei acionária não definem prazo limite para a integralização da contribuição, devendo o contrato e o estatuto social prever regras supletivas e consequências em caso de descumprimento. 
Nas limitadas o artigo 1.058 do Código Civil determina que, em caso de não integralização das cotas sociais, os outros sócios possam integralizá-las ou transferi-las a terceiros, com devolução do valor eventualmente pago, deduzindo-se os juros, encargos e despesas com a mora. O artigo 1.058 remete ao 1.004 que, por sua vez, determina que haja notificação prévia para o cumprimento da obrigação, em trinta dias, caso em que os demais sócios podem optar pela exclusão do sócio ou pela redução do capital social, com diminuição do montante de cotas de propriedade do sócio remisso. Tanto a exclusão do sócio quanto a redução do capital inviabilizam o projeto de venture capital. No primeiro caso, a exclusão inviabiliza a possibilidade de cooperação entre os sócios, essencial para o desenvolvimento das atividades. No segundo caso, a redução de capital conduz à insuficiência de recursos para executar o projeto.

Nas limitadas, a solidariedade entre os sócios pela integralização do capital amplia a responsabilidade dos não faltosos, porém a responsabilidade individual estará limitada ao valor total do capital social estipulado para a sociedade.

Nas sociedades anônimas, em caso de não integralização, o artigo $107^{166}$ da lei acionária autoriza a companhia a promover processo de execução contra o acionista remisso para cobrança das importâncias devidas. O boletim de subscrição de ações funciona como título extrajudicial, pré-constituído em favor da sociedade, que ocupa o polo ativo da ação de cobrança. Alternativamente, é possível mandar vender as ações

\footnotetext{
${ }^{166}$ Lei n. 6.404/76, art. 107. Verificada a mora do acionista, a companhia pode, à sua escolha: I - promover contra o acionista, e os que com ele forem solidariamente responsáveis (artigo 108), processo de execução para cobrar as importâncias devidas, servindo o boletim de subscrição e o aviso de chamada como título extrajudicial nos termos do Código de Processo Civil; ou II - mandar vender as ações em bolsa de valores, por conta e risco do acionista. $\S 1^{\circ}$ Será havida como não escrita, relativamente à companhia, qualquer estipulação do estatuto ou do boletim de subscrição que exclua ou limite o exercício da opção prevista neste artigo, mas o subscritor de boa-fé terá ação, contra os responsáveis pela estipulação, para haver perdas e danos sofridos, sem prejuízo da responsabilidade penal que no caso couber. $\$ 2^{\circ} \mathrm{A}$ venda será feita em leilão especial na bolsa de valores do lugar da sede social, ou, se não houver, na mais próxima, depois de publicado aviso, por 3 (três) vezes, com antecedência mínima de 3 (três) dias. Do produto da venda serão deduzidas as despesas com a operação e, se previstos no estatuto, os juros, correção monetária e multa, ficando o saldo à disposição do ex-acionista, na sede da sociedade. $\S 3^{\circ}$ É facultado à companhia, mesmo após iniciada a cobrança judicial, mandar vender a ação em bolsa de valores; a companhia poderá também promover a cobrança judicial se as ações oferecidas em bolsa não encontrarem tomador, ou se o preço apurado não bastar para pagar os débitos do acionista. $\S 4^{\circ}$ Se a companhia não conseguir, por qualquer dos meios previstos neste artigo, a integralização das ações, poderá declará-las caducas e fazer suas as entradas realizadas, integralizando-as com lucros ou reservas, exceto a legal; se não tiver lucros e reservas suficientes, terá o prazo de 1 (um) ano para colocar as ações caídas em comisso, findo o qual, não tendo sido encontrado comprador, a assembleia-geral deliberará sobre a redução do capital em importância correspondente.
} 
em bolsa de valores, por conta e risco do acionista faltoso, havendo solidariedade entre alienante e adquirente por até dois anos após a transferência (artigo 108) ${ }^{167}$. A solução dada pela lei acionária, da mesma forma que no Código Civil, não apresenta suficiente limitação do risco de inviabilização do projeto de venture capital, que não pode prosseguir sem a participação do acionista.

O Código Civil e a Lei das S/A não preveem incentivos suficientes para limitar os riscos de não integralização da contribuição, devendo o contrato ou estatuto social definir regras supletivas.

\section{Avaliação do risco}

\begin{tabular}{|l|l|}
\hline \multirow{2}{*}{ Grau de limi tação do risco: } & $\bullet \quad$ Na sociedade limitada: Baixo. \\
\cline { 2 - 2 } & $\bullet \quad$ Na sociedade anôni ma: Baixo. \\
\hline
\end{tabular}

\section{III.4.2.3. Limitação da responsabilidade}

\section{Definição do risco}

Devido ao alto grau de incerteza do negócio de venture capital, o sócio deseja limitar sua responsabilidade perante os demais sócios e os terceiros, porque afeta a relação risco-retorno assumida e o interesse em participar do projeto.

Durante a execução das atividades do projeto é necessário contratar com terceiros para materializar a ideia inovadora e manter o negócio em funcionamento. Projetos de venture capital costumam apresentar resultado deficitário por período significativo de tempo, especialmente nas etapas iniciais de desenvolvimento, porque a maior parcela do retorno somente se materializa ao final, quando a ideia inovadora está pronta para comercialização. Se houver ampliação da responsabilidade do sócio perante terceiros, haverá menor interesse em participar do negócio, porque eventual fracasso do

\footnotetext{
${ }^{167}$ Lei n. 6.404/76, art. 108. Ainda quando negociadas as ações, os alienantes continuarão responsáveis, solidariamente com os adquirentes, pelo pagamento das prestações que faltarem para integralizar as ações transferidas. Parágrafo único. Tal responsabilidade cessará, em relação a cada alienante, no fim de 2 (dois) anos a contar da data da transferência das ações.
} 
projeto terá que ser custeado com recursos adicionais dos sócios, notadamente o investidor, que dispõe dos recursos. O tipo legal deve modular este incentivo sem descuidar da necessária proteção aos credores que contratam com a sociedade, porque o insucesso do projeto não deve ser transferido a terceiros, para não haver externalização de prejuízos.

O tipo que preveja ampliação da responsabilidade do sócio perante os demais sócios ou os terceiros será considerado inferior a outro que não estabeleça o aumento do risco individual. A avaliação é comparativa.

Os principais riscos de constituição referem-se à regra geral de responsabilidade predisposta nos tipos legais durante a permanência do sócio no negócio e depois de seu desligamento, se houver dissociação. Após a constituição da sociedade, durante a execução das atividades de projeto, também se avalia se a modificação decorrente de aumento ou redução do capital social afeta a responsabilidade individual assumida e o risco dos terceiros que contratam com a sociedade.

\section{Formas de limitação do risco}

A responsabilidade da sociedade limitada perante terceiros é plena e distinta da dos sócios (artigo 1.052 do Código Civil), modulando os riscos assumidos por estes. Da mesma forma na sociedade anônima, na qual a responsabilidade dos acionistas é limitada ao preço de emissão das ações subscritas ou adquiridas (artigo $1^{\circ}$ da lei acionária).

Negócios de venture capital em desenvolvimento apresentam, geralmente, passivo superior ao ativo e fluxo de caixa negativo nos primeiros anos de desenvolvimento. $\mathrm{O}$ aumento de capital social pode ser necessário para fazer frente a novas necessidades e diminuir o déficit, especialmente porque o negócio ainda não produz receitas suficientes para manter a operação. Já a redução de capital pode ser realizada quando houver perdas decorrentes do desenvolvimento do projeto ou quando houver capital social superior ao necessário para execução das atividades. 
No aumento de capital das anônimas é obrigatória a deliberação por assembleiageral de acionistas e aplicação do direito de preferência para evitar o risco de diluição da participação dos sócios (artigo 170 da lei acionária); há previsão equivalente no Código Civil para as limitadas (artigo 1.081, caput). A lei acionária autoriza o aumento após a realização de três quartos do capital social (artigo 170, caput), mas, nas limitadas, o capital deve estar totalmente integralizado, conferindo, neste caso, maior proteção aos credores.

A redução de capital é decisão tomada pelos sócios na hipótese de haver perdas irreparáveis ou se o capital for excessivo em relação ao objeto social. Em negócios de venture capital, a perda irreparável é o prejuízo decorrente de insucesso do desenvolvimento da ideia inovadora, situação que costuma ocorrer com frequência em negócios sujeitos a alto grau de incerteza. A existência de capital social excessivo é menos provável porque o negócio inovador costuma requerer recursos adicionais não previstos pelos sócios no momento da constituição.

A redução de capital decorrente de perdas irreparáveis é restrita ao montante dos prejuízos acumulados nas anônimas (artigo 173, caput), não prevista pelo Código Civil para as sociedades limitadas (artigo 1.083), o que pode levar ao entendimento de que, nestas, a redução de capital pode ultrapassar as perdas, aumentando o risco dos credores.

Para as limitadas e também para as anônimas, a redução por motivo de capital excessivo autoriza a oposição do credor quirografário por título líquido, implicando no pagamento do crédito ou depósito judicial do montante devido ${ }^{168}$. Nos dois tipos contratuais não há proteção equivalente aos credores em caso de redução de capital por motivo de perdas irreparáveis, situação que, em negócios de venture capital, costuma ser mais frequente e causar-lhes maiores prejuízos.

\footnotetext{
${ }^{168}$ Nas limitadas, o artigo 1.082 do Código Civil autoriza a oposição do credor quirografário por título líquido anterior à data da redução do capital, até noventa dias depois da publicação da ata de assembleia que aprovar a redução (artigo 1.084), prazo que, nas anônimas, é de sessenta dias (artigo 174, capute $\S^{\circ}$, da lei acionária). A redução de capital se efetiva se houver depósito judicial da importância devida ou prova do pagamento do crédito (artigo 174, §2 $2^{\circ}$ da Lei das S/A; artigo 1.084, §2² do Código Civil).
} 
Por fim, a responsabilidade ulterior pelas obrigações sociais amplia a responsabilidade individual do sócio que se desliga do negócio, mas fundamenta-se na proteção aos credores e à sociedade. Nas limitadas, o arti go 1.086 do Código Civil, que remete ao 1.032, determina que o sócio excluído, o retirante e os herdeiros do sócio falecido sejam responsáveis, por dois anos, pelas obrigações anteriores, contraídas pela sociedade, a partir do momento da averbação da alteração contratual que modificar o vínculo social. A Lei das S/A não prevê a responsabilização ulterior do acionista, reduzindo o risco decorrente de ampliação da responsabilidade individual.

$\underline{\text { Avaliação do risco }}$

\begin{tabular}{|l|ll|}
\hline \multirow{2}{*}{ Grau de limi tação do risco: } & $\bullet \quad$ Na sociedade limitada: Médio. \\
\cline { 2 - 2 } & $\bullet \quad$ Na sociedade anôni ma: Médio. \\
\hline
\end{tabular}

\section{III.4.3. Riscos de alocação do poder de decisão}

\section{III.4.3.1. Quoruns deliberativos}

\section{Definição do risco}

Em projetos de venture capital, a deliberação social requer a combinação de distintos "pontos de vista" sobre o direcionamento do negócio, sendo os argumentos técnicos fornecidos pelo empreendedor e os estratégicos indicados pelo investidor. Pode haver diferenças entre as perspectivas dos sócios e desalinhamento dos interesses, levando a dissenso nas deliberações sociais, com possibilidade de haver imobilização da sociedade.

Por um lado, se o processo deliberativo apresentar excessiva rigidez e quoruns deliberativos muito elevados, pode favorecer o exercício irregular do poder de veto, que ocorre quando o sócio se opuser à aprovação de deliberações para obter vantagens pessoais. Neste caso, o poder de veto permite viabilizar a estratégia de hold-up, isto é, de adiamento ou impedimento ao desenvolvimento das atividades, visando a obter benefícios. Por outro lado, se houver quoruns deliberativos insuficientes, pode haver 
predominância de um dos sócios nas deliberações nas quais seria importante a participação dos demais e, neste caso, o poder de veto pode servir para limitar o risco de decisão tomada por apenas um dos sócios. As duas situações podem levar à indefinição a respeito das variáveis usadas para instruir o procedimento decisório, resultando em maior instabilidade e imprevisibilidade das deliberações sociais.

Importa debater se os quoruns deliberativos legais são rígidos e elevados, facilitando a execução da estratégia de hold-up, ou se há possibilidade de negociação dos quoruns deliberativos, limitando o risco. Se o poder de veto favorecer o empreendedor, seu exercício pode levar à adoção da estratégia de hold-up e obrigar o investidor a concordar com a forma como pretende conduzir as atividades. Se o veto for usado pelo investidor pode servir como ameaça crível ao empreendedor para garantir o regular desenvolvimento das atividades, porque o poder de veto pode ser utilizado para interromper o fornecimento de recursos ao projeto.

Limitamos nossa análise a este aspecto dos quoruns deliberativos, pois permite discutir o principal risco de negócios de venture capital: a imobilização do processo decisório pela adoção da estratégia de hold-up.

\section{Formas de limitação do risco}

Os quoruns deliberativos são predispostos em lei e de observação obrigatória pela sociedade limitada ou anônima, mas o poder de veto manifesta-se de maneira diferente nos dois tipos contratuais. Tanto nas limitadas quanto nas anônimas não há possibilidade de redução dos quoruns legais, mas pode haver aumento de quorum se houver previsão contratual.

A limitação do poder de veto ocorre quando as partes decidem não aumentar o quorum deliberativo para determinadas matérias, valendo-se somente dos quoruns legais. Se os quoruns forem naturalmente elevados pela legislação, haverá menor "espaço" para negociação entre os sócios e menores possibilidades de limitação do exercício irregular do poder de veto. 
Para as limitadas, o Código Civil estabelece quoruns elevados para diversas matérias: unanimidade, maioria de três quartos do capital social, maioria de dois terços do capital social, mais de metade do capital social, maioria absoluta e maioria dos presentes ${ }^{169}$. Os quoruns legais podem ser considerados rígidos, facilitando a execução do poder de veto nestas sociedades, especialmente no caso do artigo 1.076, I, do Código Civil, que determina maioria de três quartos do capital para deliberações que impliquem em modificação do contrato social, hipótese genérica que pode ampliar excessivamente os riscos de exercício irregular do poder de veto.

Para as anônimas, a regra geral da lei acionária (artigo $129, \S 1^{\circ}$ ) determina que as deliberações sociais se deem por maioria absoluta de votos, não se computando os votos em branco. Exige-se unanimidade em situações específicas e não há quoruns de dois terços ou três quartos ${ }^{170,171}$. Nas anônimas há maior liberdade de configuração dos quoruns, o que permite limitar, por negociação entre os acionistas fundadores, o exercício do poder de veto. Essa diferença em relação às limitadas indica que na sociedade anôni ma há maior diversificação dos riscos de alocação indevida do poder de decisão entre os acionistas para matérias as quais a estratégia de hold-up inviabilizar o

\footnotetext{
${ }^{169}$ Os principais quoruns de deliberação nas limitadas são os seguintes: 1) unanimidade: para designação de administradores não sócios, enquanto o capital não estiver integralizado (artigo 1.061), e para dissolução de pleno direito da sociedade (artigos 1.087, 1.044 e 1.033, II);2) maioria de três quartos do capital social: para modificação do contrato social, incorporação, fusão e dissolução da sociedade, e cessação do estado de liquidação (artigos 1.076, I; 1.071, V, VI);3) maioria de dois terços do capital social: para nomeação de administrador não sócio, após a integralização do capital (artigo 1.061), e destituição de sócio nomeado administrador no contrato social, se este não dispuser de maneira diversa (artigo $1.063, \S 1^{\circ}$ ); 4) mais de metade do capital social: para designação de administradores em ato separado, destituição de administradores não sócios, estabelecimento de sua remuneração, quando não prevista no contrato social, pedido de recuperação judicial (artigos 1.071, II, III, IV e VIII; 1.076, II) e exclusão de sócios (artigo 1.085); 5) maioria absoluta: para dissolução de pleno direito da sociedade estabelecida por tempo indeterminado (artigos 1.087, 1.044 e 1.033 , III); 6) maioria dos presentes: para aprovação das contas da administração, nomeação, destituição e julgamento das contas apresentadas pelo liquidante (artigos 1.071, I e VII; e 1.076, III), assim como nos demais casos previstos em lei ou no contrato social, se este não exigir maioria mais elevada (artigos 1.072).

${ }^{170}$ Para as companhias, a lei acionária exige unanimidade nas seguintes situações: 1) distribuição de dividendo inferior ao obrigatório ou retenção da totalidade do lucro líquido (artigo $202, \S 3^{\circ}$ );2) aprovação da operação de transformação da sociedade (incorporação, fusão ou cisão), salvo se prevista no estatuto social, caso em que autoriza o direito de retirada do sócio dissidente, se não houver renúncia expressa ao direito, prevista no estatuto social (artigo 221);3) autorização para pagamento de participação nos resultados aos administradores de companhia fechada com menos de vinte acionistas (artigo 294).

${ }^{171}$ Para as companhias fechadas, COMPARATO relembra que a redação original do parágrafo $1^{\circ}$ do artigo 129 da Lei das S/A proibia a unanimidade para situações em que os acionistas desejassem aumento de quorum, exigência que foi retirada da redação final, para melhor se adaptar à realidade dessas sociedades. (COMPARATO, Fabio K. A natureza da sociedade anônima e a questão da derrogabilidade das regras legais de "quorum" nas assembleias gerais e reuniões do conselho de administração. Revista de Direito Mercantil Industrial Econômico e Financeiro, São Paulo, Ano XVII, v. 27, Nova Série, 1978, p. 94).
} 
regular desenvolvimento das atividades.

Em venture capital, o quorum superior pode funcionar como incentivo positivo em duas situações: 1) para que o empreendedor possa melhor disciplinar o poder do investidor, se este detiver a maioria do capital votante e adotar atitude que inviabilize a alocação de recursos necessários ao regular desenvolvimento das atividades; 2) para o investidor que detiver participação minoritária, mantendo poder de veto sobre determinadas deliberações para modular a alocação de recursos ao projeto e orientar os negócios sociais.

Entretanto, o quorum superior pode funcionar como incentivo negativo quando facilitar o exercício da estratégia de hold-up. A principal hipótese ocorre quando o empreendedor detém o poder de veto e o usa para obrigar o investidor a fornecer recursos adicionais ao projeto. Como o empreendedor tem afinidade pessoal com a atividade, atribui menor importância ao consumo excessivo de recursos pelo projeto, porque estes provêm do investidor. Neste caso, o veto viabiliza a estratégia de hold-up pelo empreendedor, isto é, impede o regular andamento do projeto.

Como os quoruns deliberativos são elevados e inflexíveis nas limitadas, há maiores dificuldades para modular o uso indevido do poder de veto. Nas anônimas há melhores condições para definir limites ao exercício do veto, porque o quorum superior deve ser previamente negociado entre os acionistas. $\mathrm{O}$ risco tem, portanto, maior possibilidade de diversificação nas sociedades anônimas, mas não pode ser completamente eliminado em nenhum dos dois tipos legais.

\section{Avaliação do risco}

\begin{tabular}{|l|l|}
\hline \multirow{2}{*}{ Grau de limi tação do risco: } & $\bullet \quad$ Na sociedade limitada: Baixo. \\
\cline { 2 - 2 } & $\bullet \quad$ Na sociedade anôni ma: Médio. \\
\hline
\end{tabular}




\section{III.4.3.2. Alinhamento prévio de interesses}

\section{Definição do risco}

Como o empreendimento de venture capital está sujeito a inúmeros riscos que podem levar a dissenso sobre a forma de condução do negócio, os sócios podem considerar necessário alinhar, previamente, determinados interesses críticos para o sucesso do projeto, porque a medida evita os altos custos de renegociação e reduz a possibilidade de adoção de comportamentos oportunistas durante o desenvolvimento das atividades.

Negócios de venture capital têm apenas dois sócios e o alinhamento prévio de interesses implica em vinculação de "todos" os sócios, podendo estabilizar as relações internas na sociedade sem necessidade de haver frequentes modificações no contrato social, medida que pode reduzir os custos de desenvolvimento das atividades.

Se não houver possibilidade de alinhamento prévio de interesses entre os sócios, a renegociação deve ocorrer mediante deliberação social e pode implicar em alteração do contrato ou estatuto social, resultando em maiores riscos para o negócio, em especial a possibilidade de adoção da estratégia de hold-up.

\section{$\underline{\text { Formas de limitação do risco }}$}

O alinhamento prévio de interesses é obtido mediante celebração de acordo parassocial, definido como o pacto que estipula regras entre os sócios para alinhar interesses, evitando a necessidade de frequentes modificações do contrato social para viabilizar decisões críticas para o sucesso do negócio. O acordo parassocial não elimina o risco, mas pode permitir sua limitação parcial, reduzindo os efeitos negativos, porque permite a contratação antecipada das "regras do jogo" entre os sócios. Os acordos podem servir para estabelecer o alinhamento de voto nas deliberações, maior controle sobre a cessão de participações societárias durante a execução do projeto e definição de regras a respeito de outras matérias essenciais em negócios de venture capital. 
O Código Civil não determina regras para elaboração de acordos parassociais nas sociedades limitadas, ao contrário da lei acionária, cujo artigo $118^{172}$ estabelece a possibilidade de celebração de acordo de acionistas.

A elaboração de acordo parassocial nas limitadas é compatível com a liberdade de contratar, porém é inoponível aos não signatários e a terceiros, pois carece de normas que tornem obrigatória a publicidade do acordo. A Lei das S/A permite a elaboração de acordo de acionistas e viabiliza a redução de assimetrias informacionais, pois somente é oponível a terceiros se for arquivado na sede social da companhia e averbado nos livros sociais ${ }^{173}$.

O Código Civil não pró́be a elaboração dos acordos, podendo levar ao entendimento de que sociedades limitadas com regência supletiva da Lei das S/A possam fazer uso da norma contida no artigo 118 desta lei. A hipótese parece conflitar com o disposto no artigo 1.054 do Código Civil, que determina que o contrato social mencione as determinações contidas no parágrafo único do artigo 997. Este, por sua vez, torna ineficaz em relação a terceiros qualquer pacto em separado, contrário ao disposto no contrato social. O tema não é pacífico, mas pode levar ao aumento da instabilidade de negócios de venture capital que adotem o tipo das limitadas, devido à insegurança jurídica a respeito da aplicação do acordo parassocial e sua oponibilidade a terceiros.

Negócios de venture capital possuem apenas dois sócios, empreendedor e investidor, e determinados acordos parassociais, na prática, alinharão os interesses de "todos" os sócios, permitindo maior estabilidade a certas deliberações sociais ou outros arranjos importantes, como direitos de preferência ou cláusulas de venda conjunta do ne gócio ${ }^{174}$.

\footnotetext{
${ }^{172}$ Lei n. 6.404/76, artigo 118. Os acordos de acionistas, sobre a compra e venda de suas ações, preferência para adquiri-las, exercício do direito a voto, ou do poder de controle deverão ser observados pela companhia quando arqui vados na sua sede.

${ }^{173}$ Lei n. $6.404 / 76$, artigo $118, \S 1^{\circ}$ As obrigações ou ônus decorrentes desses acordos somente serão oponíveis a terceiros, depois de averbados nos livros de registro e nos certificados das ações, se emitidos.

${ }^{174}$ As cláusulas de venda conjunta do negócio são denominadas de drag along e tag along, e minimizam o risco de adoção de estratégia oportunista de opor-se à decisão de venda com o objetivo de renegociar o valor da participação. A "venda conjunta" pode ser aplicada em negócios de venture capital, porém somente ao final do empreendimento, quando a ideia inovadora é comercializada. As primeiras, também chamadas de
} 
Esse efeito pode ser alcançado tanto nas limitadas quanto nas anônimas, mas nas limitadas pode haver dúvidas quanto à possibilidade de elaboração de acordos em separado. Em consequência, a medida terá que constar do contrato social das limitadas, sujeitando-se aos quoruns deliberativos internos requeridos para modificação do contrato.

Tema polêmico na doutrina é o estabelecido nos parágrafos $8^{\circ}$ e $9^{\circ}$ do artigo $118^{175}$, a respeito da vinculação obrigatória de voto pelos signatários do acordo, medida que, entende-se, pode restringir a independência do voto proferido em assembleia-geral. Parte da doutrina entende que o objetivo da lei é reforçar a obrigatoriedade de cumprimento do acordo, evitando o uso de estratégias de abstenção de voto e de voto proferido contrariamente ao pacto ${ }^{176}$. A crítica não procede em negócios de venture capital, nos quais a vinculação pode ser do interesse dos sócios porque reduz o risco de adoção da estratégia de hold-up. Além disso, nas sociedades fechadas sempre há alternativas para monitoramento do negócio e defesa dos interesses dos acionistas. Segundo CLARK, a vinculação, para ser efetiva, deve ser explicitada em estatuto social, não pode ser contrária à lei, deve respeitar a liberdade de julgamento do administrador, não contrariar o interesse da companhia nem prejudicar credores ${ }^{177}$.

Nas limitadas, que apresentam quoruns deliberativos mais rígidos e elevados, a

\footnotetext{
bring along, são obrigações contratuais de venda conjunta das ações a terceiros, nas quais todos os acionistas vendem conjuntamente as ações para um comprador (LAVCA (Latin America Venture Capital Association). Guia para term sheets de venture capital e private equity, 2012. Disponível em: <www.lavca.org>. Acesso em 19.02.2013, p. 20). As segundas são direitos de venda conjunta com garantia de preço mínimo das ações com direito a voto, detidas pelos minoritários, correspondentes a, no mínimo, $80 \%$ do preço das ações que integram o bloco de controle (artigo 254-A da lei acionária). O que se busca é garantir que os acionistas possam pré-contratar a decisão futura de venda do negócio, que tem maior valor como going concern, isto é, negócio funcional e integrado, cujo valor é maior que a soma dos valores dos bens e direitos considerados isoladamente (CLARK, Robert C. Corporate law. New York: Aspen Law and Business, 1986, p. 14).

${ }^{175}$ Lei n. 6.404/76, artigo $118, \S 8^{\circ} \mathrm{O}$ presidente da assembleia ou do órgão colegiado de deliberação da companhia não computará o voto proferido com infração de acordo de acionistas devidamente arquivado. $\S 9^{\circ} \mathrm{O}$ não comparecimento à assembleia ou às reuniões dos órgãos de administração da companhia, bem como as abstenções de voto de qualquer parte de acordo de acionistas ou de membros do conselho de administração eleitos nos termos de acordo de acionistas, assegura à parte prejudicada o direito de votar com as ações pertencentes ao acionista ausente ou omisso e, no caso de membro do conselho de administração, pelo conselheiro eleito com os votos da parte prejudicada.

${ }^{176}$ Análise crítica sobre a vinculação de voto apresentada por: GORGA, Érica. Direito societário atual. São Paulo: Ed. Campus, 2013, pp. 195-208.

${ }^{177}$ CLARK, Robert C. Corporate law. New York: Aspen Law and Business, 1986, pp. 781-784.
} 
possibilidade de elaboração de acordo parassocial poderia servir para reduzir o risco de hold-up, porém, a maior incerteza jurídica quanto à possibilidade de aplicação do acordo e sua oponibilidade a terceiros não permite limitar o risco.

\section{$\underline{\text { Avaliação do risco }}$}

$$
\text { Grau de limi tação do risco: }
$$

- Na sociedade limitada: Baixo.

- Na sociedade anônima: Médio.

\section{III.4.3.3. Limitação do direito de voto}

\section{Definição do risco}

Em negócios de venture capital pode ser necessário restringir o direito de voto sobre determinadas matérias consideradas críticas para o negócio, limitando a participação de um ou mais sócios. A justificativa para a limitação de voto reside no alto grau de incerteza do empreendimento, que pode exi gir que certas decisões críticas para o negócio sejam tomadas pelo sócio que esteja em melhores condições de avaliar os riscos existentes.

Por um lado, se não for possível restringir o direito de voto, pode haver aumento do risco de imprevisibilidade das deliberações sociais ou de imobilização da sociedade. Por outro lado, o direito de voto é considerado essencial e sua restrição não pode ser absoluta para não excluir o sócio da participação no processo deliberativo interno da sociedade.

Negócios de venture capital têm apenas dois sócios, empreendedor e investidor. Se houver limitação absoluta do direito de voto de um, o outro decidirá sozinho sobre matérias relevantes, podendo haver risco de a decisão ser inadequada, pois refletirá seus interesses pessoais. Nesses empreendimentos, os sócios podem apresentar interesses contrapostos, porque o interesse em obter retorno sobre o investimento pode conflitar com a forma de condução das atividades técnicas do projeto. 
Se a limitação de voto for imposta ao investidor, o empreendedor poderá adotar estratégia de desenvolvimento das atividades que implique em consumo excessivo de recursos, conduzindo à inviabilidade do negócio. Se a limitação de voto for imposta ao empreendedor, pode haver expropriação pelo investidor, especialmente no momento da venda do negócio finalizado, porque, nesta etapa, o investidor detém informação assimétrica sobre o mercado e os potenciais compradores do negócio, podendo usá-la para expropriar o empreendedor de sua participação nos resultados do negócio.

A limitação do direito de voto apresenta outros aspectos que não trataremos, porque os elementos indicados são suficientes para comparação dos tipos contratuais quanto ao tratamento dos riscos descritos.

\section{Formas de limitação do risco}

Para as limitadas, o Código Civil não estabelece se as cotas sociais podem, ou não, ter limitação quanto ao direito de voto. As cotas sociais representam somente frações do capital social, conforme previsão do artigo 1.055 do Código Civil. Como o direito de voto é considerado essencial, não pode ser restringido por convenção entre as partes $^{178}$.

Nas sociedades anônimas é possível o estabelecimento de classes ou espécies de ações com direitos e deveres específicos ${ }^{179}$, que encontram limites na própria lei acionária $^{180}$, viabilizando a limitação do direito de voto. A limitação precisa ser

\footnotetext{
${ }^{178}$ Em favor dessa interpretação, para as sociedades limitadas regidas supletivamente pelas normas da sociedade simples, o artigo 1.010 do Código Civil estabelece serem as deliberações sociais tomadas por maioria de votos, contados segundo o valor das cotas de cada sócio, sem exclusão de qualquer cota. Segundo o artigo, não há restrições a direitos políticos, nem mesmo daqueles que estejam em conflito de interesses com a sociedade. $\mathrm{O} \$ 3^{\circ}$ do artigo em tela confirma esse entendimento, ao não proibir o voto do sócio que esteja em conflito de interesses com a sociedade, mas tornando-o responsável por perdas e danos caso a deliberação for aprovada graças a seu voto e houver comprovação de que houve benefício pessoal e prejuízo à sociedade.

${ }^{179}$ As ações de companhias são valores mobiliários que incorporam múltiplas naturezas, representando fração ideal do capital social, direitos e obrigações dos acionistas, parcela do acervo econômico da sociedade e a medida da participação do acionista no negócio. (MELLO FRANCO, Vera H.; SZTAJN, Rachel. Direito empresarial II. $2^{\text {a }}$ Ed., São Paulo: Revista dos Tribunais, 2009, pp. 87-88).

${ }^{180}$ As normas da lei acionária, contidas nos artigos $11,12,15$ a 19 , e no inciso IV do artigo 24 , tratam das espécies e classes de ações ordinárias e preferenciais com ou sem direito de voto (artigo 11), definindo obrigações, vantagens e limites para a fruição de benefícios. É permitida a criação de classes de ações
} 
negociada entre os sócios para ser efetivada nas anônimas, devendo constar do estatuto social. Com isso, a limitação de voto pode reduzir o risco de exercício irregular do poder de veto nas situações em que for necessário evitar o uso da estratégia de hold-up pelo sócio.

Nos contratos de venture capital em espécie analisados em nossa pesquisa empírica, constatamos a presença de ações ordinárias e também de preferenciais com direito de voto restrito a matérias especificadas no estatuto social, porém não percebemos a utilização de ações preferenciais sem direito de voto. A razão para tal configuração pode decorrer da preferência dos investidores por deter combinação de ações ordinárias e preferenciais com direito de voto restrito, que viabilizam maior controle sobre as deliberações consideradas críticas para o sucesso do empreendi mento.

O inciso I do artigo 16 da lei acionária, aplicável às companhias, estabelece que as ações ordinárias possam ser de classes diversas, em função de sua conversibilidade em ações preferenciais. A medida facilita a atração de capitais para negócios de venture capital, mas pode levar à modificação na proporção das ações com direito de voto detidas pelos sócios, alteração das relações de poder na sociedade e diluição da participação do sócio que não detiver ações conversíveis.

Normalmente, durante o desenvolvimento do projeto, o investidor detém ações preferenciais e ordinárias, utilizando-as para orientar a estratégia da companhia. No momento da venda do negócio concluído, a conversibilidade permite aumentar a parcela de ações com direito de voto que podem ser transferidas a terceiros, produzindo dois efeitos contrapostos: por um lado, amplia-se a quantidade de ações "úteis" ao comprador que deseje controlar o negócio, beneficiando os sócios no momento da venda; por outro lado, há risco de diluição da participação do empreendedor, porque as ações conversíveis são normalmente de propriedade do investidor.

Em negócios de venture capital, as atividades se desenvolvem com recursos próprios dos sócios, porque há baixa probabilidade de obtenção de empréstimos no

ordinárias e preferenciais com direitos específicos (artigos 15 a 17) e possibilidade de alteração posterior (artigo 12). 
mercado e não há lucros a distribuir durante a execução do projeto, uma vez que o retorno sobre o investimento, se existir, ocorrerá ao final do desenvolvimento das atividades. Entretanto, as ações preferenciais de companhia que ainda não possuam direito de voto podem adquiri-lo, caso não haja distribuição de dividendos por três exercícios sociais consecutivos (artigo $111, \S 1^{\circ}$ ), direito que os acionistas conservarão até o pagamento, se tais dividendos não forem cumulativos, ou até que sejam pagos os valores atrasados. Da mesma forma, ficam suspensas as limitações de voto impostas a ações preferenciais com direito de voto restrito $\left(\$ 2^{\circ}\right)$. O prazo de três exercícios sociais tem sido considerado excessivo pela doutrina, havendo dúvidas quanto à possibilidade de sua redução ${ }^{181}$. Na maioria dos negócios de venture capital a crítica não procede, porque o prazo de três exercícios sociais, se anuais, será insuficiente para a produção de lucros e sua distribuição aos sócios. Neste caso, haverá elimi nação da limitação de voto durante a execução do projeto e consequente alteração da quantidade de ações com direito de voto, aumentando o risco de imprevisibilidade nas deliberações sociais, mesmo nos casos em que o negócio de venture capital ainda não apresentar condições econômicas para distribuição de lucros. Com base na norma contida no artigo 111, §3º, o estatuto social pode determinar a não aplicação dessas regras durante 0 desenvolvimento das atividades de implantação do empreendimento inicial da companhia, suspendendo o exercício do direito em negócios de venture capital, desde que seja possível haver definição precisa e suficiente dessas atividades, tarefa de difícil execução em negócios sujeitos a alto grau de incerteza.

Nas limitadas não parece possível haver limitação do direito de voto, ao passo que nas anônimas a limitação é viável, mas pode levar ao risco de expropriação de um sócio pelo outro, devendo ser regulada pelo estatuto social.

\section{$\underline{\text { Avaliação do risco }}$}

\begin{tabular}{|c|c|}
\hline \multirow{2}{*}{ Grau de limitação do risco: } & - Na sociedade limitada: Baixo. \\
\hline & - Na sociedade anônima: Médio. \\
\hline
\end{tabular}

${ }^{181}$ Argumentos apresentados por: GORGA, Érica. Direito societário atual. São Paulo: Ed. Campus, 2013, pp. $164 ; 170$. 


\section{III.4.3.4. Invalidação de deliberações sociais}

\section{Definição do risco}

Negócios de venture capital apresentam inúmeras incertezas durante seu desenvolvimento e os custos derivados dos erros de decisão costumam ser significativos.

Se os efeitos das decisões inadequadas não puderem ser revertidos em tempo hábil, retornando a sociedade ao seu estado anterior, pode haver prejuízo irreparável ao desenvolvimento do projeto, porque não haverá como desfazer os efeitos das atividades realizadas após a deliberação invalidada.

Se, ao contrário, houver possibilidade de reversão dos efeitos, a medida deve ocorrer o mais rapidamente possível, para minimizar os riscos adicionados pelo erro de decisão, que podem levar à ampliação dos custos do negócio ou à sua inviabilidade.

\section{$\underline{\text { Formas de limitação do risco }}$}

A disciplina de invalidação de decisões assembleares nas sociedades limitadas e anônimas tem levado a distintas interpretações jurisprudenciais, com prejuízo à estabilidade dos empreendimentos que se utilizam desses tipos contratuais.

O parágrafo $4^{\circ}$ do artigo 1.078 do Código Civil estabelece o prazo legal de dois anos para anulação da aprovação das demonstrações financeiras eivadas de erro, dolo ou simulação ${ }^{182}$. O prazo traz insegurança aos participantes do negócio de venture

\footnotetext{
${ }^{182}$ Código Civil, artigo 1.078. A assembleia dos sócios deve realizar-se ao menos uma vez por ano, nos quatro meses seguintes à ao término do exercício social, com o objetivo de: I - tomar as contas dos administradores e deliberar sobre o balanço patrimonial e o de resultado econômico; II - designar administradores, quando for o caso; III - tratar de qualquer outro assunto constante da ordem do dia. $§ 1^{\circ}$ Até trinta dias antes da data marcada para a assembleia, os documentos referidos no inciso I deste artigo devem ser postos, por escrito, e com a prova do respectivo recebimento, à disposição dos sócios que não exerçam a administração. $\S 2^{\circ}$ Instalada a assembleia, proceder-se-á à leitura dos documentos referidos no parágrafo antecedente, os quais serão submetidos, pelo presidente, a discussão e votação, nesta não podendo tomar parte os membros da administração e, se houver, os do conselho fiscal. $\S 3^{\circ} \mathrm{A}$ aprovação, sem reserva, do balanço patrimonial e do de resultado econômico, salvo erro, dolo ou simulação, exonera de responsabilidade
} 
capital, pois os efeitos concretos da maioria das deliberações sociais dificilmente poderão ser revertidos após o decurso de tal prazo.

Nos demais casos de invalidade, para as limitadas com regência supletiva da Lei das S/A, é aplicável o prazo decadencial de dois anos para vícios de convocação, deliberação e voto de cotistas, alcançando as deliberações conexas, com base na norma contida no artigo 286 da lei acionária ${ }^{183}$. Nas limitadas com regência supletiva das normas predispostas para as sociedades simples não há regra definida e a jurisprudência tem aplicado o parágrafo único do artigo 48 do Código Civil ${ }^{184}$, que apresenta prazo decadencial de três anos para anulação de deliberações ${ }^{185}$.

Para as companhias, aplica-se a norma do artigo 286 da lei acionária, que estabelece o prazo legal de dois anos para prescrição do direito de anular deliberações sociais tomadas em assembleias irregularmente convocadas ou instaladas, violadoras da lei ou do estatuto social, ou eivadas de erro, dolo, fraude ou simulação.

A jurisprudência tem entendido que não se aplica a prescrição do direito comum às sociedades anônimas, por incompatibilidade da norma com a necessidade de maior

\footnotetext{
os membros da administração e, se houver, os do conselho fiscal. $\S 4^{\circ}$ Extingue-se em dois anos o direito de anular a aprovação a que se refere o parágrafo antecedente.

${ }^{183}$ Lei das S/A, artigo 286. A ação para anular as deliberações tomadas em assembleia-geral ou especial, irregularmente convocada ou instalada, violadoras da lei ou do estatuto, ou eivadas de erro, dolo, fraude ou simulação, prescreve em 2 (dois) anos, contados da deliberação.

${ }^{184}$ Código Civil, artigo 48. Parágrafo único. Decai em três anos o direito de anular as decisões a que se refere este artigo, quando violarem a lei ou estatuto, ou forem eivadas de erro, dolo, simulação ou fraude.

${ }^{185}$ EMENTA: Decadência - Sociedade limitada - Anulação de assembleia convocada para deliberar sobre exclusão de sócio por justa causa - Regência supletiva da LSA pre vista no contrato social - Inaplicabilidade, porém, do art. 286 da LSA diante da pre visão expressa no CC/02 acerca do prazo decadencial para o sócio excluído pedir a anulação da assembleia (art. 48) - Ação anulatória ajuizada dentro do prazo decadencial de três anos - Decreto de decadência afastado - Apelação provida para este fim. Sociedade limitada - Expulsão de sócio por justa causa (CC, art. 1.085) - Quórum qualificado estabelecido no contrato social $(85 \%$ do capital social) - Inaplicabilidade do art. $1.074, \S 2^{\circ}$, da LSA ao caso concreto - Matéria que não diz respeito diretamente ao sócio excluído - Maioria absoluta que se refere ao valor das cotas e não ao número de sócios votantes (CC, art. 1.085, e art. 30 do contrato social neste sentido) - Hipótese em que embora exclusão tenha sido aprovada por unanimidade, sócios votantes detinham $79,58 \%$ do capital social, percentual inferior ao exigido no contrato social da co-ré - Inobservância ao quórum deliberativo - Assembleia anulada, reintegrando-se o autor no quadro societário - Anulatória procedente - Apelação provida para este fim. Dispositivo: dão provimento ao recurso. (Apelação Cível 00012007720118260286 - Itu - 2 $2^{\mathrm{a}}$ Câmara Reservada de Direito Empresarial - Relator Ricardo Negrão - 16/10/2012 - Votação Unânime - Voto ${ }^{\circ}$ 20465). (TJ-SP, Boletim de Direito Empresarial 09 - 2012, Disponível em: <http://www.tjsp.jus.br>. Acesso em: 03.02.2013). (grifos nossos).
} 
estabilidade e segurança das companhias ${ }^{186}$. Há, entretanto, decisões judiciais considerando nulas as operações de subscrição e cessão de ações e a indenização por prejuízos decorrentes de incorporação de companhia ${ }^{187}$.

Os prazos para invalidação de deliberações sociais representam riscos adicionais ao negócio de venture capital, com baixa probabilidade de diversificação tanto nas sociedades limitadas quanto nas anônimas.

\section{Avaliação do risco}

\begin{tabular}{|l|ll|}
\hline \multirow{2}{*}{ Grau de limi tação do risco: } & $\bullet \quad$ Na sociedade limitada: Baixo. \\
\cline { 2 - 2 } & $\bullet \quad$ Na sociedade anôni ma: Baixo. \\
\hline
\end{tabular}

\section{III.4.4. Riscos de interrupção}

\section{III.4.4.1. Custos excessivos de operação}

\section{Definição do risco}

Em projetos de venture capital, os custos de operação do negócio, em especial, os relativos à realização de deliberações sociais, publicação de informações e cumprimento de obrigações de natureza tributária, trabalhista e previdenciária, podem ser significativos e inviabilizar o desenvolvimento das atividades de negócios de venture capital.

Em venture capital, a atividade é, normalmente, desenvolvida por profissionais com alto nível de especialização e elevada remuneração, o que implica em custos elevados derivados das obrigações de natureza tributária, trabalhista e previdenciária. Em nossa pesquisa empírica, esses custos foram mencionados pelos entrevistados como um entrave ao desenvolvimento de projetos inovadores no Brasil.

${ }^{186}$ TJSP, $5^{\text {a }}$ Câmara AC 262.004.1/4, Rel. Des. Marco César, j. 7.3.1996. Anotado por: LAZZARESCHI NETO, Alfredo S. Lei das sociedades por ações anotada, São Paulo: Saraiva, 2006, p. 540.

${ }^{187}$ TJRJ, $18^{a}$ Câmara. Agr. Instr. 2002.002.18667, Rel. Des. Jorge Luiz Habib, j. 2.12.2003. Anotado por: LAZZARESCHI NETO, Alfredo S. Lei das sociedades por ações anotada, São Paulo: Saraiva, 2006, p. 540. 


\section{Formas de limitação do risco}

Os custos de deliberação social e publicação de informações nas limitadas e anôni mas podem ser reduzidos.

Nas sociedades limitadas, a deliberação em assembleia será obrigatória somente se o número dos sócios for superior a dez (artigo 1.072, §1 ${ }^{\circ}$, do Código Civil) e facultativa nos demais casos. Há poucas formalidades para convocação de assembleias e reuniões de sócios, dispensadas quando todos comparecerem espontaneamente $\left(\$ 2^{\circ}\right)$ ou decidirem, por escrito, sobre a matéria objeto da deliberação $\left(\S 3^{\circ}\right)$.

Na companhia fechada é obrigatória a convocação, por carta ou telegrama, de acionista que represente $5 \%$ ou mais do capital social (artigo $124, \S 3^{\circ}$ ), sendo que para os demais a convocação ocorre mediante anúncio (artigo 124, caput), dispensado se houver comparecimento espontâneo de todos os acionistas à assembleia $\left(\S 4^{\circ}\right)$.

Assim como nas limitadas, a sociedade anônima é obrigada a publicar, periodicamente, demonstrativos financeiros (artigo 176) e obedecer a regras de escrituração e contabilização específicas (artigos 177 e seguintes). Facultativamente, a companhia fechada pode submeter-se às normas sobre publicação de demonstrações financeiras expedidas pela CVM, o que não é do interesse dos sócios porque aumenta os custos operacionais.

Para a companhia fechada com patrimônio líquido inferior a dois milhões de reais na data de levantamento do balanço patrimonial não há obrigatoriedade de elaboração e publicação da demonstração de fluxos de caixa (artigo 176, $\S 6^{\circ}$ ). IUDÍCIBUS, MARTINS, GELBCKE e SANTOS explicam que a demonstração era facultativa para a maioria das sociedades, apesar de ser recomendada, porque permite demonstrar a possibilidade de geração de fluxos positivos de caixa, a capacidade de honrar compromissos e pagar dividendos, liquidez, solvência e capacidade financeira e operacional do projeto. A demonstração passou a ser obrigatória por determinação da 
Lei n. 11.638/07 ${ }^{188}$. Em negócios de venture capital é essencial o acompanhamento dos fluxos de caixa do negócio para sinalizar a evolução do empreendi mento e os riscos associados ao desenvolvimento, razão pela qual o demonstrativo dificilmente será dispensado pelos sócios.

Se a companhia fechada enquadrar-se nas regras aplicáveis à sociedade anônima de menor porte (artigo $294^{189}$ ), isto é, apresentar, cumulativamente, menos de vinte acionistas, patrimônio líquido inferior a um milhão de reais e não controlar ou estar filiada a grupo de sociedades, pode haver significativa redução de custos operacionais. Nestes casos, o inciso I do artigo 294 permite a convocação de assembleia-geral de acionistas por anúncio e o inciso II elimina a obrigatoriedade de publicação de todos os documentos da administração indicados no artigo 133, desde que sejam arquivadas cópias autenticadas no registro de comércio, acompanhadas da respectiva ata da assembleia-geral na qual foram deliberados ${ }^{190}$.

A Lei Complementar n. 123/06 permite o enquadramento da sociedade limitada, mas não da anônima, na categoria de microempresa ou de empresa de pequeno porte,

\footnotetext{
${ }^{188}$ DE IUDÍCIBUS, Sérgio; MARTINS, Eliseu; GELBCKE, Ernesto Rubens; DOS SANTOS, Ariovaldo. Manual de contabilidade societária. $1^{\mathrm{a}}$ ed., São Paulo: Atlas, 2010, pp. 567-568.

${ }^{189}$ Lei n. 6.404/76, artigo 294. A companhia fechada que tiver menos de vinte acionistas, com patrimônio líquido inferior a $\mathrm{R} \$ 1.000 .000,00$ (um milhão de reais), poderá: I - convocar assembleia-geral por anúncio entregue a todos os acionistas, contra recibo, com a antecedência prevista no artigo 124; e II - deixar de publicar os documentos de que trata o artigo 133, desde que sejam, por cópias autenticadas, arqui vados no registro de comércio juntamente com a ata da assembleia que sobre eles deliberar. $\S 1^{\circ} \mathrm{A}$ companhia de verá guardar os recibos de entrega dos anúncios de convocação e arquivar no registro de comércio, juntamente com a ata da assembleia, cópia autenticada dos mesmos. $\S 2^{\circ}$ Nas companhias de que trata este artigo, o pagamento da participação dos administradores poderá ser feito sem observância do disposto no $\S 2^{\circ}$ do artigo 152 , desde que aprovada pela unanimidade dos acionistas. $\S 3^{\circ} \mathrm{O}$ disposto neste artigo não se aplica à companhia controladora de grupo de sociedade, ou a ela filiadas.

${ }^{190}$ Lei n. 6.404/76, artigo 133. Os administradores devem comunicar, até 1 (um) mês antes da data marcada para a realização da assembleia-geral ordinária, por anúncios publicados na forma prevista no artigo 124, que se acham à disposição dos acionistas: I - o relatório da administração sobre os negócios sociais e os principais fatos administrativos do exercício findo; II - a cópia das demonstrações financeiras; III - o parecer dos auditores independentes, se houver. IV - o parecer do conselho fiscal, inclusive votos dissidentes, se houver; e V - demais documentos pertinentes a assuntos incluídos na ordem do dia. $\S 1^{\circ}$ Os anúncios indicarão o local ou locais onde os acionistas poderão obter cópias desses documentos. $\S 2^{\circ}$ A companhia remeterá cópia desses documentos aos acionistas que o pedirem por escrito, nas condições previstas no $\S 3^{\circ}$ do artigo 124 . $\S$ $3^{\circ}$ Os documentos referidos neste artigo, à exceção dos constantes dos incisos IV e V, serão publicados até 5 (cinco) dias, pelo menos, antes da data marcada para a realização da assembleia-geral. § $4^{\circ} \mathrm{A}$ assembleiageral que reunir a totalidade dos acionistas poderá considerar sanada a falta de publicação dos anúncios ou a inobservância dos prazos referidos neste artigo; mas é obrigatória a publicação dos documentos antes da realização da assembleia. § $5^{\circ}$ A publicação dos anúncios é dispensada quando os documentos a que se refere este artigo são publicados até 1 (um) mês antes da data marcada para a realização da assembleia-geral ordinária.
} 
afetando os custos derivados das obrigações de natureza tributária, trabalhista e previdenciária. O enquadramento legal da companhia fechada é proibido pelo artigo $3^{\circ}$, $\S 4^{\circ}$, letra ' $\mathrm{x}$ ', da Lei Complementar n. 123/06, e impede que a companhia se beneficie do tratamento diferenciado e simplificado previsto pelo Regime Especial Unificado de Arrecadação de Tributos e Contribuições. A vedação independe do porte da companhia, isto é, não prospera mesmo para sociedades que se enquadrem no critério econômico de receita bruta anual inferior a três milhões e seiscentos mil reais (artigo $3^{\circ}$, I e II).

Desta forma, fica inviabilizada para a anônima a redução dos custos operacionais decorrentes das seguintes obrigações: 1) apuração e recolhimento de impostos e contribuições da União, Estados, Distrito Federal e Municípios, mediante regime único de arrecadação; 2) cumprimento, de forma simplificada, de obrigações principais e acessórias de natureza tributária, trabalhista e previdenciária. A companhia também não terá acesso facilitado a linhas especiais de crédito e financiamento nem preferência nas aquisições de bens e serviços em licitações, leilões, ou outras formas de contratação com o Poder Público.

A redução de custos propiciada pela Lei Complementar n. 123/06 pode ser insuficiente para eliminar os elevados custos dessas obrigações, mas permite redução parcial do montante para as limitadas. O risco não é diversificável para as anônimas.

\section{Avaliação do risco}

\begin{tabular}{|l|l|}
\hline \multirow{2}{*}{ Grau de limi tação do risco: } & $\bullet \quad$ Na sociedade limitada: Médio. \\
\cline { 2 - 2 } & $\bullet \quad$ Na sociedade anôni ma: Médio. \\
\hline
\end{tabular}

\section{III.4.4.2. Dissociação}

\section{Definição do risco}

Por dissociação entendemos, conforme lição de MELLO FRANCO, as diversas formas de solução do vínculo societário que leva à separação de um ou mais sócios, 
com preservação da sociedade para os demais ${ }^{191}$.

Agentes econômicos racionais que participam de negócios de venture capital permanecem em negócios que tenham probabilidade de serem bem sucedidos, retirando-se dos mal sucedidos, isto é, daqueles que apresentem desempenho inferior às expectativas dos sócios.

Empreendimentos de venture capital somente apresentam resultado positivo ao final do desenvolvimento das atividades, logo, o sócio deve permanecer até o final do projeto para recuperar o investimento realizado. Consequentemente, a dissociação somente ocorre em caso de empreendimento inviável, que não corresponda às expectativas de risco-retorno do sócio que se retira, não significando, necessariamente, que a sociedade seja insolvente ${ }^{192}$.

A decisão é tomada pelo sócio que pretende evitar a perda de novos recursos, incorridos se houver continuidade das atividades (estratégia de stop loss). Por isso, a decisão é tomada pelo investidor que fornece os recursos, porque o empreendedor tem afinidade pessoal com o projeto e prefere a continuidade das atividades.

Como há prestações personalíssimas a realizar e obrigatoriedade de colaboração entre empreendedor e investidor para desenvolvimento das atividades, a dissociação inviabiliza a continuidade do negócio.

\footnotetext{
${ }^{191}$ MELLO FRANCO, Vera H. Direito empresarial I. $3^{\text {a }}$ Ed., São Paulo: Revista dos Tribunais, 2009, p. 250.

${ }^{192}$ Por insolvência entendemos o déficit patrimonial derivado do desbalanceamento entre ativos e passivos. Insolvabilidade é a falta de liquidez para honrar os compromissos nas datas avençadas. De acordo com ROSSI, incapacidade financeira significa crise de liquidez, impossibilidade de equilibrar despesas e receitas, podendo, ou não, ter como consequência a insolvência. Incapacidade patrimonial deriva da insuficiência de ativos frente ao passivo existente. Incapacidade econômica é impossibilidade de obtenção de meios de financiamento, podendo, ou não, haver incapacidade financeira ou patrimonial. (ROSSI, Riccardo. Insolvenza, crisi di impreza e risanamento. Milano: Giuffrè, 2003, pp. 130-135). Crise patrimonial, de acordo com os economistas, é espécie de crise financeira, diferentemente do que entendem os juristas, que associam crise patrimonial à insuficiência de ativos frente aos passivos assumidos. (SZTAJN, Rachel. Comentários. In: SOUZA JR, Francisco Satiro de; PITOMBO, Antonio Sérgio A de Moraes (coord.). Comentários à lei de recuperação de empresas e falência. São Paulo: Revista dos Tribunais, 2005, p. 219). Conforme lição de MAURO PENTEADO, o comerciante pode ser insolvente e dispor de linhas de crédito no mercado, conseguindo financiar-se para saldar as dívidas correntes e evitar a impontualidade. (PENTEADO, Mauro R. Comentários. In SOUZA JR, Francisco Satiro de; PITOMBO, Antonio Sérgio A de Moraes (coord.). Comentários à lei de recuperação de empresas e falência. São Paulo: Revista dos Tribunais, 2005, pp. 7778).
} 
A dissociação também sinaliza ao mercado que a qualidade do empreendimento será inferior à esperada pelos sócios, reduzindo o interesse de novos sócios. Para o investidor, que geralmente é um fundo de investimentos, a dissociação afeta negativamente a reputação de seu administrador, porque demonstra sua incapacidade de produzir resultados positivos, levando a desinteresse dos cotistas por adquirir futuras participações em outros fundos e aumento da dificuldade para captação de recursos para novos projetos.

Se o empreendedor se dissocia, o projeto não tem como prosseguir, pois carecerá do conhecimento a respeito da forma de conduzir o desenvolvimento da ideia inovadora. Se o investidor abandona o empreendimento, este pode ser inviabilizado pela falta de recursos para realização das atividades. Nos dois casos há risco de interrupção do projeto e perda dos recursos investidos. O risco é tanto maior quanto maior for a existência de prestações personalíssimas ainda não realizadas pelos sócios.

A dissociação pode ser voluntária, quando o sócio não pretende mais continuar no negócio, ou involuntária, decorrente de decisão dos outros sócios ou de eventos não controlados pelos envolvidos, como, por exemplo, morte do sócio, falência pessoal, etc.

\section{Formas de limitação do risco}

Há diferentes formas de alcançar a dissociação e limitar o risco de interrupção do projeto. As principais hipóteses legais aplicáveis a negócios de venture capital são: 1) cessão da totalidade da participação de um sócio a outro, ou a terceiros; 2) exclusão do sócio que comete falta grave; 3) retirada de sócio (recesso) que discorda de deliberação social que lhe é prejudicial; 4) dissolução parcial da sociedade.

O quadro-resumo apresentado a seguir indica as hipóteses e a solução dada pelos tipos contratuais: 


\begin{tabular}{|c|c|c|}
\hline $\begin{array}{l}\text { Tipo: } \rightarrow \\
\text { Hipótese: }\end{array}$ & Sociedade limitada & Sociedade anônima \\
\hline $\begin{array}{l}\text { 1. Cessão da } \\
\text { totalidade da } \\
\text { participação. }\end{array}$ & $\begin{array}{l}\text { - Facilita a cessão de cotas, } \\
\text { ampliando o risco de } \\
\text { interrupção do projeto. }\end{array}$ & 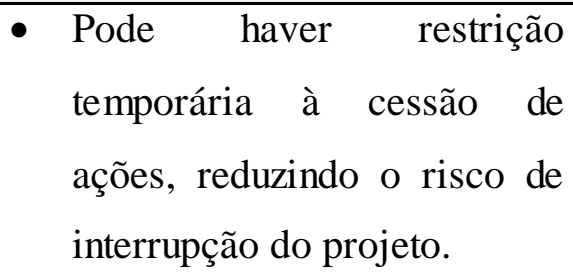 \\
\hline $\begin{array}{l}\text { 2. Exclusão de } \\
\text { sócio por falta } \\
\text { grave. }\end{array}$ & $\begin{array}{l}\text { - Exclusão apresenta } \\
\text { critérios legais amplos e } \\
\text { subjetivos, ampliando o } \\
\text { risco de interrupção do } \\
\text { projeto. A ameaça, } \\
\text { porém, não é crível. }\end{array}$ & $\begin{array}{l}\text { - } \text { Exclusão sem critérios legais } \\
\text { definidos, ampliando o risco } \\
\text { de interrupção do projeto. A } \\
\text { ameaça, porém, não é crível. }\end{array}$ \\
\hline $\begin{array}{l}\text { 3. Retirada de } \\
\text { sócio (recesso). }\end{array}$ & $\begin{array}{l}\text { - Direito de retirada amplo, } \\
\text { decorrente de } \\
\text { modificação no contrato } \\
\text { social, sem possibilidade } \\
\text { de retratação, ampliando } \\
\text { o risco de interrupção do } \\
\text { projeto. }\end{array}$ & 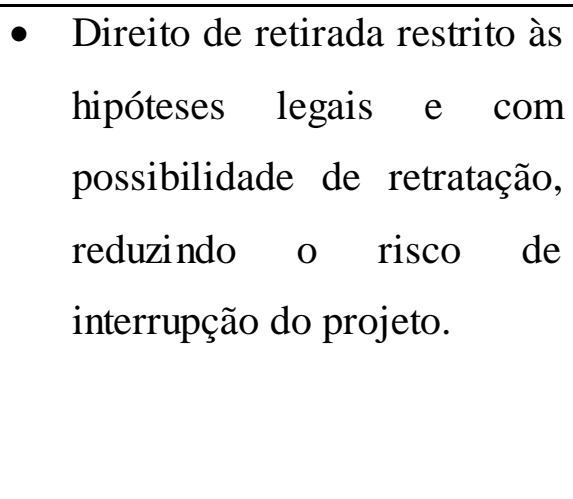 \\
\hline $\begin{array}{l}\text { 4. Dissolução } \\
\text { parcial. }\end{array}$ & $\begin{array}{l}\text { - Aplicada pela } \\
\text { jurisprudência, amplia o } \\
\text { risco de interrupção do } \\
\text { projeto. }\end{array}$ & $\begin{array}{l}\text { - Inaplicável por } \\
\text { incompatibilidade com o } \\
\text { tipo, o que reduz o risco de } \\
\text { interrupção do projeto. }\end{array}$ \\
\hline
\end{tabular}

O quadro-resumo sugere que as sociedades anônimas apresentam melhores incentivos que as limitadas para evitar a dissociação em negócios de venture capital, porém, mesmo naquelas há hipóteses que ampliam o risco de dissociação. Os argumentos que justificam a avaliação são apresentados a seguir.

\section{1) Cessão da totalidade da participação de um sócio a outro, ou a terceiros}

Negócios de venture capital têm apenas dois sócios e a cessão da participação de um ao outro inviabiliza o negócio. A cessão do investidor ao empreendedor é de 
difícil obtenção porque ele não possui recursos necessários para adquirir a participação. A cessão do empreendedor ao investidor inviabiliza a continuidade das operações porque o negócio não pode prosseguir sem o sócio que detém conhecimento exclusivo sobre a ideia inovadora e realiza prestações personalíssimas.

O artigo 1.057 do Código Civil determina que, na omissão do contrato social, o sócio da limitada pode ceder suas cotas ao outro sócio, independentemente de anuência dos demais, norma de aplicação impossível em venture capital porque há somente dois sócios, que devem concordar quanto à cessão.

Já a cessão de cotas a terceiros depende de oposição dos titulares de mais de um quarto do capital social e somente pode ser evitada se o outro sócio detiver mais de 75\% do capital social, investimento que pode ser considerado excessivo para limitar o risco de dissociação. É improvável haver cessão das cotas do empreendedor a terceiro, porque ele detém conhecimento exclusivo a respeito do desenvolvimento da ideia inovadora e sua participação não pode ser substituída por outro sócio. Mais provável é a cessão da posição do investidor a outro investidor, porém esta sinaliza que o empreendimento não apresenta a qualidade esperada pelo sócio, que reduz o interesse de terceiros em participar do negócio.

Nas companhias, o artigo 36 da lei acionária permite que os acionistas determinem a proibição temporária à livre transferência das ações, estipulada no estatuto social, desde que não se impeça, de forma arbitrária, a negociação (caput) e conte com a concordância expressa dos titulares das ações impedidas de circular (parágrafo único). A limitação é obtida por convenção entre as partes e consta do estatuto social da companhia, tornando o exercício do direito mais oneroso, ao menos temporariamente, e reduzindo, mas não eliminando, o risco de abandono do projeto pelo acionista.

Segundo CLARK, a limitação à circulação pode ser compensada com o uso de mecanismos contidos no estatuto social ou em acordos parassociais, como, por 
exemplo, o direito de primeira recusa e primeira oferta ${ }^{193}$. Entretanto, essas medidas apresentam efetividade parcial para impedir a dissociação em negócios de venture capital. $\mathrm{O}$ direito de primeira recusa determina que o acionista que receber proposta de aquisição de suas ações por terceiro deve comunicar previamente os termos aos outros sócios, para que estes decidam se querem cobrir a oferta. O direito de primeira oferta estabelece a prioridade de oferecer a venda das ações aos demais sócios, antes de propor o negócio a terceiros ${ }^{194}$. As medidas servem para que os acionistas decidam pela aceitação ou recusa de admissão de novos sócios, sem que haja impedimento à circulação das ações, pois, caso a prioridade não seja exercida no prazo avençado, o vendedor fica liberado para oferecer o negócio a terceiros. São também incapazes de evitar a dissociação porque o outro sócio pode recusar a oferta e terá que haver cessão a terceiros, inviabilizando a continuidade das atividades, pelos mesmos motivos apresentados.

Nas limitadas, a cessão de cotas é facilitada, ampliando o risco de interrupção do projeto, situação que pode ser restringida, temporariamente e de forma parcial, nas anônimas.

\section{2) Exclusão de sócio por falta grave}

Exclusão de sócio é medida coercitiva adotada em resposta à prática, pelo sócio faltoso, de atos nocivos à sociedade ou grave descumprimento de obrigações avençadas no contrato social, podendo ser deliberada pela sociedade ou requerida judicialmente.

Em venture capital importa discutir a hipótese do sócio que comete falta grave visando a ser excluído do negócio e receber o reembolso pela participação ${ }^{195}$. É

\footnotetext{
${ }^{193}$ Conforme: CLARK, Robert C. Corporate law. New York: Aspen Law and Business, 1986, pp. 764-765.

${ }^{194}$ LAVCA (Latin America Venture Capital Association). Guia para term sheets de venture capital e private equity, 2012. Disponível em: <www.lavca.org>. Acesso em 19.02.2013, p. 19.

${ }^{195}$ As demais hipóteses de exclusão de sócio indicadas pelo Código Civil para as limitadas, porém omitidas na lei acionária, também levam à interrupção do projeto, porém são hipóteses nas quais não haveria diferença significativa entre as sociedades limitadas e anônimas, por se tratam de exclusão por causas involuntárias ou, no caso do sócio remisso, porque o tema já foi tratado em outra seção desta tese. As hipóteses descartadas são: sócio remisso (artigo 1.058 do Código Civil; artigos 106 a 108 da lei acionária); falência pessoal de sócio; liquidação de suas cotas (parágrafo único do artigo 1.030 do Código Civil). A primeira refere-se ao sócio que não integraliza as cotas sociais subscritas, sendo sua exclusão realizada de pleno direito. A segunda aplica-se ao sócio declarado pessoalmente falido, submetendo as cotas sociais ao procedimento coletivo de
} 
hipótese de mais provável aplicação após o término das atividades de desenvolvimento da ideia inovadora, porém antes da operação de venda do negócio finalizado, pois, neste intervalo de tempo, o projeto técnico está concluído e um sócio pode ter interesse em excluir o outro para se beneficiar da operação de venda a terceiros. Ainda assim é hipótese de difícil aplicação, porque requer o cometimento de falta grave e prova de prejuízo a negócio que já está concluído, no qual não mais há atividades a serem realizadas.

Nas limitadas, o artigo 1.085 do Código Civil, que remete ao 1.030, autoriza a exclusão quando a maioria entender que um ou mais sócios estejam colocando em risco a continuidade do negócio, em virtude de atos de inegável gravidade. O Código Civil determina que conste do contrato social a previsão de exclusão extrajudicial por justa causa $^{196}$ e que seja assegurado amplo direito de defesa ao acusado na assembleia de cotistas convocada em "tempo hábil" para deliberar a respeito dos atos praticados ${ }^{197}$. A exclusão judicial é fundamentada no artigo 1.030 e determina a necessidade de prova da falta grave. Como essas situações ocorrem somente após o término do desenvolvimento das atividades técnicas do projeto de venture capital, não há mais “tempo hábil” para exclusão e dificilmente haverá prova de falta grave, pois não há atividades adicionais a serem desempenhadas pelo faltoso. A exceção pode ocorrer em relação às atividades relacionadas à operação de venda do negócio, desempenhadas

execução por quantia certa contra devedor insolvente (artigo 748 e seguintes do Código de Processo Civil). A terceira refere-se ao sócio que teve sua cota liquidada para pagamento de dívidas pessoais.

${ }^{196} \mathrm{O}$ artigo 1.085 do Código Civil estabelece que a exclusão por justa causa deva estar expressamente prevista no contrato social, porém a determinação é desnecessária, uma vez que a justa causa é da essência do ato de exclusão, um evento de extrema gravidade que elimina direito essencial do sócio de permanecer na sociedade, não podendo ser decisão imotivada ou arbitrária. (MELLO FRANCO, VERA H. Resolução do vínculo societário em relação ao sócio - reescrevendo antigos temas perante o CC 2002. In: GORGA, Érica; PELA, Juliana K. (org.), Estudos avançados de direito empresarial, São Paulo: Ed. Campus, 2013, pp. 103104). Trata-se, na verdade, de cláusula resolutiva implícita que não necessita de previsão contratual. Assim já se posicionava a doutrina em relação à antiga sociedade por quotas de responsabilidade limitada. (LEÃES, Luiz Gastão P. B. Exclusão extrajudicial de sócio em sociedade por quotas. Revista de Direito Mercantil, Industrial, Econômico e Financeiro, Ano XXXIV, n. 100, Out./Dez. 1995, pp. 88-89; 91).

${ }^{197}$ Segundo VERÇOSA e BARROS, o conceito de "tempo hábil", previsto no artigo 1.085, pode levar a problemas de interpretação. Segundo eles, a noção de "falta grave no cumprimento de obrigações" é expressão de difícil avaliação, especialmente no caso de sócio que somente empresta capital, podendo a exclusão ser obtida com abuso da maioria. Acrescentam que a exclusão de minoritário depende de justa causa, nos casos em que o excluído contribui para colocar em risco a continuidade do negócio, medida polêmica porque vem alicerçada em critérios legais subjetivos e de difícil elucidação. (VERÇOSA, Haroldo M. D.; BARROS, Zanon P. Breve estudo comparativo esquemático das sociedades limitadas no direito anterior e no novo Código Civil. Revista de Direito Mercantil, Industrial, Econômico e Financeiro, Ano XLII, n. 130, Abr./Jun. 2003, pp. 89-90; 92-93). 
pelo investidor, mas também será difícil haver prova da falta grave, porque a informação assimétrica a respeito da venda do negócio favorece o investidor e é de difícil observação pelo empreendedor.

Nas sociedades anônimas não há previsão legal de exclusão por falta grave, entretanto, quando o acionista atua com abuso de direito e em conflito de interesses com a companhia, MELLO FRANCO e SZTAJN entendem aplicável a exclusão ${ }^{198}$. Neste caso, em negócios de venture capital, aplicam-se as mesmas observações indicadas para as limitadas.

Tanto nas limitadas quanto nas anônimas, o sócio pode se valer do cometimento intencional de falta grave para tentar ser excluído do negócio pelo outro sócio, recebendo seus haveres. A exclusão durante o desenvolvimento do projeto inviabiliza a continuidade das atividades, que não podem prosseguir sem a colaboração do outro sócio, logo, em venture capital, não pode ser considerada ameaça crível, porque o sócio remanescente não tem incentivos para excluir o outro. A exclusão ao final do projeto também é de difícil obtenção, porque não há mais atividades a desempenhar, inviabilizando a prova da falta grave. A alternativa para esses casos será a dissolução total da sociedade. Entretanto, o projeto é deficitário durante o desenvolvimento, havendo poucas possibilidades de recuperação do capital antes de sua finalização.

A exclusão de sócio por falta grave apresenta critérios legais amplos e subjetivos nas limitadas, ampliando o risco de interrupção do projeto, ao contrário das anônimas, nas quais não há critérios legais determinados. Nos dois casos a ameaça de exclusão não é crível, devido às características do negócio de venture capital, que requer colaboração obrigatória entre as partes.

\section{3) Recesso (retirada) de sócio}

O exercício do direito de recesso, ou retirada, é decisão de rompimento do vínculo com a sociedade, tomada pelo sócio que discordar de deliberação social que lhe

\footnotetext{
${ }^{198}$ MELLO FRANCO, Vera H.; SZTAJN, Rachel. Direito empresarial II. $2^{\text {a }}$ Ed., São Paulo: Revista dos Tribunais, 2009, pp. 216-217.
} 
seja prejudicial. É aplicável às hipóteses expressamente previstas e implica em reembolso da participação. Trata-se de direito essencial que pode ser invocado pelo sócio que votou contra, absteve-se de votar, ou esteve ausente à assembleia ${ }^{199}$, condicionado à implantação da deliberação, sem haver necessidade de demons tração do prejuízo $^{200}$. Trata-se de declaração de vontade do dissidente que não depende de aceitação pela sociedade, mas está condicionada à não retratação pela assembleia-geral, em tempo hábil, caso em que desaparece o fundamento para exercício do direito ${ }^{201}$.

A retirada ocorre durante o desenvolvimento das atividades e inviabiliza a continuidade do projeto, devido à dependência de colaboração entre os sócios. O sócio retirante terá dificuldades em receber o reembolso, porque o projeto é deficitário durante o desenvolvimento. A decisão de exercer o recesso ocorre se o dissidente entender que a modificação contratual implicará em futura perda total do investimento realizado, caso em que o reembolso permite antecipar seus efeitos, evitando dedicar tempo adicional a projeto inviável (estratégia de stop loss). Pode acontecer também na hipótese do empreendedor que prefere interromper o desenvolvimento de atividades de projeto cujo direcionamento não esteja adequado, segundo seu entendimento.

Nas limitadas, o direito de retirada está previsto no arti go 1.077 do Código Civil, que o autoriza nos casos de modificação do contrato social, fusão, cisão ou incorporação da sociedade ${ }^{202}$. As hipóteses aplicam-se a qualquer modificação relevante no contrato social, ampliando os riscos de interrupção do projeto. Não há

\footnotetext{
${ }^{199}$ O Superior Tribunal de Justiça tem confirmado que o conceito de dissidente é abrangente, incluindo aquele que comparece e vota contrariamente à deliberação, o ausente e também aquele que, por qualquer razão, deixa de votar (STJ, REsp. 570028/AP, Rel. Min. Castro Filho, DJU 2.5.2005, p. 340), mas não pode ser exercido por aquele que votou favoravelmente à deliberação. Anotado por: LAZZARESCHI NETO, Alfredo S. Lei das sociedades por ações anotada, São Paulo: Saraiva, 2006, pp. 241; 243.

${ }^{200}$ Parte da jurisprudência, entretanto, tem se posicionado em favor da necessidade de demonstração dos prejuízos para justificar a retirada. O Superior Tribunal de Justiça tem exigido a demonstração, pelo acionista dissidente. (STJ, REsp. 31515/SP, Rel. Min. Sál vio de Figueiredo Teixeira, DJU 22.4.1996, p. 12575; RSTJ 85/250; RT 730/182) (LAZZARESCHI NETO, Op.cit., p. 238).

${ }^{201}$ GUERREIRO, José A. T. Direito de retirada: um limite ao princípio majoritário na sociedade anônima. Revista de Direito Mercantil, Industrial, Econômico e Financeiro, Ano XLVIII, n. 151/152, Jan./Dez. 2009, pp. 14-15; SZTAJN, Rachel. Direito de recesso. Tese de doutorado. São Paulo: Faculdade de Direito da Universidade de São Paulo. 1982, pp. 14-15; 17-18; 23-28; 303-306.

${ }^{202}$ Apesar da omissão legal, o dispositivo também é aplicável à cisão, também uma espécie de transformação societária que implica em modificação do contrato social. Conforme: VERÇOSA, Haroldo M. D.; B ARROS, Zanon P. Breve estudo comparativo esquemático das sociedades limitadas no direito anterior e no novo Código Civil. Revista de Direito Mercantil, Industrial, Econômico e Financeiro, Ano XLII, n. 130, Abr./Jun. 2003 , p. 85.
} 
previsão de retratação, podendo haver dúvidas se a nova assembleia-geral teria o condão de cancelar o exercício do direito de recesso regularmente manifestado. Para as limitadas regidas supletivamente pela lei acionária há autores que entendem ser cabível a aplicação do artigo $137, \S 3^{\circ}$ para ratificação ou retratação da primeira deliberação, e outros que rejeitam a possibilidade ${ }^{203}$.

Para as companhias, o direito de recesso previsto na lei acionária apresenta rol numerus clausus $^{204,205}$, aplicando-se a hipóteses específicas e mais restritivas ${ }^{206}$. É suficiente a comunicação da decisão de exercer o direito, não sendo necessário que o dissidente tenha participado do pleito ou votado contrariamente à deliberação. A assembleia-geral pode retratar-se da decisão (artigo 137, $\S 3^{\circ}$ ), impedindo o exercício do direito, quando convoca nova assembleia para invalidar a primeira deliberação ${ }^{207}$. A retratação possibilita a reavaliação dos efeitos da primeira decisão, em especial o aumento dos riscos de inviabilidade do negócio, derivados da decisão de dissociação tomada pelo acionista que ainda tem obrigações personalíssimas a realizar.

Em negócios de venture capital, a aplicação do direito de recesso reduz os riscos de interrupção do projeto, limitando a dissociação de maneira mais efetiva nas sociedades anônimas que nas limitadas, que apresentam hipóteses mais amplas. A previsão de retratação com reversão dos efeitos da decisão aumenta a segurança jurídica a respeito dos resultados da deliberação e a possibilidade de continuidade do negócio, sendo alcançável nas sociedades anônimas, porém de interpretação incerta nas limitadas.

Consequentemente, há ampliação do risco de interrupção do projeto nas limitadas e melhores formas de sua limitação nas anônimas.

\footnotetext{
${ }^{203}$ Correntes doutrinárias expostas por: MELLO FRANCO, VERA H. Resolução do vínculo societário em relação ao sócio - reescrevendo antigos temas perante o CC 2002. In: GORGA, Érica; PELA, Juliana K. (org.), Estudos avançados de direito empresarial, São Paulo: Ed. Campus, 2013, p. 99.

${ }^{204}$ MELLO FRANCO, Vera H.; SZTAJN, Rachel. Direito empresarial II. $2^{\text {a }}$ Ed., São Paulo: Revista dos Tribunais, 2009, p. 207.

${ }^{205}$ TJRJ, $1^{\circ}$ Grupo de Câmaras Cíveis, Emb. Infr. 200/94, Rel. Des. Laerson Mauro, j. 15.2.1995; TJSP, $1^{\circ}$ Grupo de Câmaras Cíveis, AR 247.278-1, Rel. Des. Vasconcellos Pereira, j. 5.11.1997. (LAZZARESCHI NETO, Alfredo S. Lei das sociedades por ações anotada, São Paulo: Saraiva, 2006, p. 237).

${ }^{206}$ As hipóteses legais e seus efeitos estão previstos nos artigos 136 e 137 da lei acionária.

${ }^{207}$ MELLO FRANCO, Vera H.; SZTAJN, Rachel. Op.Cit., 2009, p. 207.
} 


\section{4) Dissolução parcial}

A dissolução parcial é criação jurisprudencial que determina que o sócio que requereu a dissolução total seja afastado da sociedade, preservando-a para os demais sócios. MELLO FRANCO entende que é hipótese de dissolução total ficta, na qual o contrato social não mais está em vigor e o capital social passa a ser tangível, devendo ser devolvido aos acionistas ${ }^{208}$.

Negócios de venture capital não podem prosseguir sem a participação de um dos sócios, devido à necessidade de intrínseca colaboração entre eles. Em negócios de venture capital pode ser usada pelo sócio que deseja interromper perdas (estratégia de stop loss) e não mais continuar as atividades, porém é improvável haver reembolso do capital, porque o projeto é deficitário durante o desenvolvimento.

O Código Civil não prevê normas para tratar da dissolução parcial de limitadas, uma decisão de extrema gravidade em negócios de venture capital, porque inviabiliza a continuidade do negócio. A dissolução parcial é hipótese de aplicação jurisprudencial às limitadas, fundamentada no direito do sócio de se retirar da sociedade, em especial nas por tempo indeterminado, e também no interesse em preservação desta para os demais sócios, hipótese que não condiz com as características desses negócios.

Nas sociedades anônimas, conforme lição de MELLO FRANCO e SZTAJN, a dissolução parcial é inaplicável, porque o artigo 206 da lei acionária prevê hipóteses taxativas de dissolução total e o inciso $\mathrm{V}$ do artigo 109 garante o direito essencial do acionista de retirar-se da sociedade nos casos previstos em lei. Entretanto, como apontam as autoras, o tema não é pacífico na doutrina, havendo aqueles que entendem ser possível sua aplicação ${ }^{209}$.

\footnotetext{
${ }^{208}$ MELLO FRANCO, VERA H. Resolução do vínculo societário em relação ao sócio - reescrevendo antigos temas perante o CC 2002. In: GORGA, Érica; PELA, Juliana K. (org.), Estudos avançados de direito empresarial, São Paulo: Ed. Campus, 2013, p. 107.

${ }^{209}$ MELLO FRANCO, Vera H.; SZTAJN, Rachel. Direito empresarial II. $2^{\text {a }}$ Ed., São Paulo: Revista dos Tribunais, 2009, pp. 272-274.
} 
A dissolução parcial aumenta o risco de dissociação e interrupção do projeto, sendo permitida nas limitadas e dificultada nas anônimas. Como o negócio não pode prosseguir sem o sócio que se desliga, alternativa será a dissolução total da sociedade.

\section{$\underline{\text { Avaliação do risco }}$}

\begin{tabular}{|l|ll|}
\hline \multirow{2}{*}{ Grau de limi tação do risco: } & $\bullet \quad$ Na sociedade limitada: Baixo. \\
\cline { 2 - 2 } & $\bullet \quad$ Na sociedade anôni ma: Médio. \\
\hline
\end{tabular}

\section{III.4.4.3. Dissolução}

\section{Definição do risco}

Projeto de venture capital inviável que apresente desempenho insatisfatório, segundo as expectativas dos sócios, deve ser encerrado antes do término do desenvolvimento para reduzir as perdas futuras (estratégia de stop loss).

A dissolução do negócio é medida extrema, adotada pelos sócios ou prevista em lei. Dissolução é termo que especifica o procedimento de extinção da sociedade e liquidação de seu patrimônio, no qual o capital social deve ser devolvido aos sócios. Serve, portanto, apenas para negócios de venture capital ainda em desenvolvimento, pois empreendimentos bem sucedidos são comercializados e não liquidados.

Assim como na dissociação, há diferentes perspectivas do empreendedor e do investidor a respeito da decisão de dissolução, porque o primeiro tem afinidade pessoal com o projeto, preferindo mantê-lo em funcionamento pelo maior tempo possível, ao passo que o segundo prefere liquidar as perdas mais rapidamente, evitando o consumo desnecessário de recursos por ele fornecidos. O dissenso pode se manifestar na deliberação social que aprova ou rejeita a dissolução. A impossibilidade de alcançar a decisão de interromper as perdas (stop loss) somente agrava o prejuízo e, se não sanada a tempo, leva à perda total dos recursos investidos.

Há quatro enquadramentos e distintas possibilidades de haver decisão correta ou 
erros de decisão ${ }^{210}$.

\begin{tabular}{|c|c|c|}
\hline $\begin{array}{ll} & \text { Decisão: } \rightarrow \\
\text { Hipótese: } & \end{array}$ & Dissolução alcançada & Dissolução evitada \\
\hline Negócio inviável & Não há erro de decisão & Erro do tipo I \\
\hline Negócio viável & Erro do tipo II & Não há erro de decisão \\
\hline
\end{tabular}

Não há erro de decisão quando o negócio é inviável e opta-se pela dissolução, nem quando o negócio é viável e a dissolução é evitada. Se o negócio é inviável e a dissolução é evitada há erro de decisão (erro do tipo I), assim como quando o negócio é viável e a dissolução é alcançada (erro do tipo II). Em negócios de venture capital, o erro do tipo I tem maior probabilidade de ocorrência que o erro do tipo II, porque o desempenho insatisfatório é mais facilmente percebido pelos sócios durante a execução.

Em venture capital importa discutir a possibilidade de dissolução convencional, deliberada pelos sócios, e a dissolução judicial fundamentada na inexeqüibilidade do fim social, porque são hipóteses mais prováveis de interrupção do projeto.

\section{$\underline{\text { Formas de limitação do risco }}$}

A dissolução convencional das limitadas (artigo 1.033, III) é obtida por deliberação dos sócios, por maioria absoluta, na sociedade de tempo indeterminado ${ }^{211}$. Nas sociedades anônimas (artigo 206, alínea “c”) é obtida por deliberação pela assembleia-geral, por quorum majoritário ${ }^{212}$.

\footnotetext{
${ }^{210}$ A definição de negócio viável e as hipóteses de erro de decisão são detalhadas no Capítulo II.

${ }^{211}$ Os artigos 1.033, 1.044 e 1.087, do Código Civil, enumeram as hipóteses de dissolução de pleno direito da sociedade limitada: 1) vencimento do tempo de duração, salvo se, vencido este e sem oposição de sócio, não entrar a sociedade em liquidação, caso em que se prorrogará por tempo indeterminado (artigo 1.033, I);2) consenso unânime dos sócios (artigo 1.033, II); 3) deliberação dos sócios, por maioria absoluta, na sociedade de tempo indeterminado (artigo 1.033, III); 4) falta de pluralidade de sócios, se não reconstituída no prazo de cento e oitenta dias, exceto se o único sócio remanescente requerer a transformação da sociedade em empresa individual de responsabilidade limitada (artigos 1.033, IV e parágrafo único, e 980-A); 5) extinção de autorização para funcionar (artigo 1.033, V); 6) declaração de falência (artigo 1.044). O artigo 1.035 do Código Civil autoriza os sócios a prever, no contrato social, outras causas de dissolução da sociedade para as limitadas, caso em que se deve aplicar o quorum do artigo 1.033, III, se a sociedade for de tempo indeterminado, porque, neste caso, também se cuida de dissolução convencional.

${ }^{212}$ Para as sociedades anônimas, a lei acionária estabelece regras específicas para dissolução total de pleno direito (artigos 206 e seguintes). O inciso I do artigo 206 estabelece cinco hipóteses: 1) término do prazo de
} 
Nos dois casos, se o empreendedor de venture capital detiver a maioria do capital votante, tende a não desejar interromper o projeto, porque tem afinidade pessoal com seu desenvolvimento e os recursos financeiros são fornecidos pelo investidor. Neste caso, haverá dificuldade de adoção da estratégia de stop loss por deliberação dos sócios, com risco de perda total dos recursos investidos tanto nas limitadas quanto nas anônimas. Se o sócio majoritário for o investidor, a decisão de dissolução será mais facilmente obtida, porque ele tem maior interesse em interromper as perdas.

Nestes casos, a elevação de quorum para a decisão de dissolução pode estabelecer poder de veto para viabilizar a extinção de negócio inviável ou preservar o empreendimento viável. O Código Civil não indica se é possível às partes contratarem o aumento de quorum para as limitadas, mas a lei acionária permite a elevação (artigo $136, \mathrm{X}^{213}$ ) nas anônimas. Nestes casos, quando o poder de veto for necessário, sua implantação por meio do aumento de quorum é viabilizada nas anônimas.

No caso de inexeqüibilidade do fim social, a dissolução judicial é adotada para as limitadas (artigo 1.034, II, do Código $\mathrm{Civil}^{214}$ ) e também para as anônimas (artigo 206, II, “b”, da lei acionária ${ }^{215}$ ). Nenhum dos dois tipos societários elimina o risco de decisão incorreta, porque a legislação em vigor exige verificação da prova da inexeqüibilidade e, de acordo com o balanço patrimonial e os demonstrativos financeiros, o negócio de venture capital em desenvolvimento é deficitário, porém pode ser projeto viável, porque o retorno sobre o investimento se dará ao final do empreendimento. Desta forma, haverá risco de o julgador incorrer em erro de avaliação sobre a possibilidade de continuidade do negócio, risco não diversificável tanto para as

\footnotetext{
duração, se não for prorrogado (alínea "a"); 2) previsão estatutária (alínea "b"); 3 ) deliberação pela assembleia-geral (alínea "c"); 4) unipessoalidade da sociedade, se não remediada nos prazos legais, exceção à transformação da companhia em empresa individual de responsabilidade limitada (alínea "d"); 5) extinção de autorização para funcionar (alínea "e").

${ }_{213}^{213}$ Lei n. 6.404/76, artigo 136. É necessária a aprovação de acionistas que representem metade, no mínimo, das ações com direito a voto, se maior quorum não for exigido pelo estatuto da companhia cujas ações não estejam admitidas à negociação em bolsa ou no mercado de balcão, para deliberação sobre: (...) X dissolução da companhia.

${ }^{214}$ Código Civil, artigo 1.034. A sociedade pode ser dissolvida judicialmente, a requerimento de qualquer dos sócios, quando: II - exaurido o fim social, ou verificada a sua inexeqüibilidade.

${ }^{215}$ Lei n. 6.404/76, artigo 206. Dissolve-se a companhia: II - por decisão judicial: b) quando provado que não pode preencher o seu fim, em ação proposta por acionistas que representem $5 \%$ (cinco por cento) ou mais do capital social;
} 
limitadas quanto para as anônimas.

$\underline{\text { Avaliação do risco }}$

Grau de limitação do risco:

- Na sociedade limitada: Baixo.

- Na sociedade anôni ma: Médio. 


\section{CONCLUSÃO}

Negócios de venture capital objetivam o desenvolvimento de atividades inovadoras e estão sujeitos a incertezas que dificultam a avaliação objetiva do empreendimento. A transformação da incerteza em risco permite eliminar parte da subjetividade, antecipar eventos danosos e estimar o retorno esperado. Se o risco de dano for diversificável, isto é, puder ser limitado pela adoção de estratégias de contenção, haverá maior interesse em contratar o negócio.

A limitação do risco depende de haver regras adequadas para organizar a cooperação, levando à maior possibilidade de obtenção de retornos elevados no momento da finalização do projeto. Os tipos legais "ideais" devem ser aqueles que permitem limitar os riscos mais importantes do negócio e o tratamento das contingências que surjam, em especial: o alto risco de insucesso do empreendimento; necessidade de sigilo e confidencialidade da tecnologia desenvolvida; maior controle sobre o desenvolvimento do projeto e a tomada de decisões estratégicas; possibilidade de interrupção do empreendimento.

Os tipos que organizam sociedades empresárias fechadas são mais aptos a limitar os riscos descritos. Entretanto, ainda que o modelo das sociedades anônimas

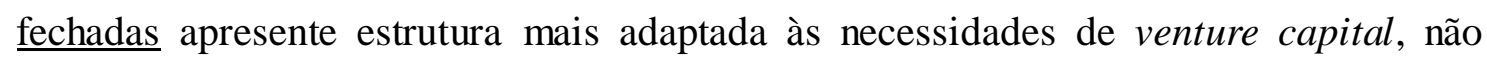
alcança limitação suficiente dos riscos analisados. Já as sociedades limitadas que, originalmente, ofereciam suporte a negócios que requeriam maior flexibilidade de organização, não podem ser utilizadas, pois as definições do Código Civil tornaram estas sociedades inflexíveis e impossibilitaram a suficiente limitação dos riscos. Os demais tipos contratuais estudados não apresentam as características mínimas requeridas para organização dos empreendimentos de venture capital.

O quadro-resumo comparativo, apresentado a seguir, apresenta a classificação atribuída ao grau de limitação dos riscos pelos tipos contratuais ${ }^{216}$ :

\footnotetext{
${ }^{216}$ O quadro resume a avaliação comparativa do grau estimado de limitação dos riscos obtido pela utilização dos tipos contratuais analisados, segundo o critério apresentado: Alto: limitação plena ou suficiente dos principais riscos do negócio, sem necessidade de alteração ou complementação do tipo contratual; Médio:
} 


\begin{tabular}{|l|l|c|c|}
\hline \multirow{4}{*}{ Tipo de risco } & \multirow{2}{*}{ Item de risco } & \multicolumn{2}{|c|}{ Grau de limitação do } \\
\cline { 3 - 4 } & & $\begin{array}{c}\text { Sociedade } \\
\text { limitada }\end{array}$ & $\begin{array}{c}\text { Sociedade } \\
\text { anônima }\end{array}$ \\
\hline \multirow{2}{*}{$\begin{array}{l}\text { Riscos de } \\
\text { contratação }\end{array}$} & Contribuição dos sócios & Baixo & Médio \\
\cline { 2 - 4 } & Integralização da contribuição & Baixo & Baixo \\
\cline { 2 - 4 } Riscos de alocação \\
do poder de decisão & Limitação da responsabilidade & Médio & Médio \\
\cline { 2 - 4 } & Quoruns deliberativos & Baixo & Médio \\
\cline { 2 - 4 } & Limitação do direito de voto & Baixo & Médio \\
\cline { 2 - 4 } & Invalidação de deliberações sociais & Baixo & Baixo \\
\hline \multirow{2}{*}{$\begin{array}{l}\text { Riscos de } \\
\text { interrupção }\end{array}$} & Custos excessivos de operação & Médio & Médio \\
\cline { 2 - 4 } & Dissociação & Baixo & Médio \\
\cline { 2 - 4 } & Dissolução & Baixo & Médio \\
\hline
\end{tabular}

Os riscos de contratação do negócio de venture capital são mais facilmente limitados com o uso do tipo das anônimas. Entretanto, as evidências empíricas analisadas indicam a existência de negócios organizados sob a forma das limitadas, pois, nesta etapa do projeto, ainda há muitas incertezas sobre o desenvolvimento das atividades e os sócios não conseguem avaliar todos os riscos.

Quanto aos riscos de alocação do poder de decisão entre os sócios do negócio de venture capital há vantagens em favor das anônimas, tornando o processo deliberativo mais estável, mas, mesmo assim, a alocação do poder de decisão pode levar à instabilidade do processo decisório nos dois tipos contratuais.

Quanto aos riscos de interrupção prematura do negócio, há vantagens para as anônimas, especialmente nas hipóteses de dissociação e dissolução, porém há, também, inadequação parcial do tipo.

limitação parcial dos riscos, com necessidade de alteração do tipo ou estabelecimento de cláusulas contratuais complementares; Baixo: limitação insuficiente dos riscos. 
Concluímos indicando que não há tipo contratual adequado para limitar os riscos do negócio de venture capital, entretanto, o modelo analítico que utilizamos é incompleto, razão pela qual apresentamos sugestões para o aprofundamento da pesquisa:

- Aprofundar a aplicação dos tipos legais às características do negócio de venture capital. Em função do escopo limitado, ativemo-nos à discussão dos principais aspectos, sem esgotar os temas;

- Melhorar a sistematização do negócio de venture capital do ponto de vista da teoria dos contratos, em especial da proteção aos credores;

- Aprofundar a discussão sobre a necessidade de revisão da estrutura predisposta no Código Civil para as sociedades limitadas;

- Estender e detalhar a análise dos incentivos institucionais à inovação, especialmente os derivados da legislação tributária, trabalhista, previdenciária e a relativa aos direitos de propriedade imaterial;

- Construir um modelo lógico-formal matemático para explicar os comportamentos dos sócios e credores de acordo com as características do mercado brasileiro ${ }^{217}$;

- Aprofundar a discussão a respeito dos métodos de avaliação de investimentos em venture capital, visando sua adaptação à realidade brasileira.

\footnotetext{
${ }^{217}$ A realização de estudos estatísticos sobre contratos em espécie no mercado de venture capital brasileiro é dificultada pela ausência de bases de dados especializadas e pela natureza de confidencialidade dos projetos. Há di versas fontes de dados sobre contratos, disponíveis para o mercado norte-americano e europeu, como, por exemplo, Harvard Management Company, Kemper Financial Services, Venture Economics, Venture One, etc. (GOMPERS, Paul A.; LERNER, Josh. The venture capital cycle. $2^{\text {nd }}$ ed., Cambridge: MIT Press, 2006, pp. 519-532).
} 


\section{BIBLIOGRAFIA}

AGHION, Philippe; BOLTON, Patrick. An incomplete contracts approach to financial contracting. Review of Economic Studies, vol. 59, n. 200, pp. 473-495. July, 1992. Disponível em: <http://www.jstor.org/stable/2297860>. Acesso em: 27.01.2012.

AKERLOF, George. The market for lemons: quality uncertainty and the market mechanism. Quarterly Journal of Economics, Vol. 84, n. 3, pp. 488-500, August 1970.

ASCARELLI, Tullio. Problemas das sociedades anônimas e direito comparado. $1^{\text {a }}$ ed., São Paulo: Saraiva, 1945.

ASQUINI, Alberto. Os perfis da empresa. Tradução: COMPARATO, Fabio K. Revista de Direito Mercantil, Industrial, Econômico e Financeiro, Ano XXXV, n. 104, pp. 109-126, Out./Dez. 1996.

ASSOCIAÇÃO BRASILEIRA DAS INSTITUIÇÕES DO MERCADO DE CAPITAIS (ANBIMA). Mapa de incentivos. Disponível em: <http://www.anbima.com.br/informe_legislacao/arqs/MapaIncentivos.pdf>. Acesso em: 16.02.2013.

AZEVEDO, Paulo F. "Economia dos contratos". In ZYLBERSTAJN, Decio; SZTAJN, Rachel (coord.). Direito e Economia - Análise Econômica do Direito e das Organizações. São Paulo: Campus, 2005, pp. 102-136.

BAIRD, Douglas G.; HENDERSON, M. Todd. Other people's money. John M. Olin Law \& Economics, Working Paper n. 359 (2D series). September, 2007. Disponível em: <http://papers.ssrn.com/paper.taf?abstract_id=1017615>. Acesso em: 11.03.2011.

BAPTISTA, Luiz O. A “joint venture” - uma perspectiva comparatista. Revista de Direito Mercantil Industrial Econômico e Financeiro, São Paulo, Ano XX, v. 42, pp. 39-59, Abr./Jun. 1981. 
BARROW, Michael. Estatística para economia, contabilidade e administração. Tradução: Antonio Z. Sanvicente. São Paulo: Ática, 2008.

BASSO, Maristela. Contratos internacionais do comércio. $2^{\mathrm{a}}$ Ed., Porto Alegre: Livraria do Advogado Editora, 1998.

Manual prático das associações comerciais. Porto Alegre: Livraria do Advogado, 2a ed., 1998.

BECK, Mário. Na Coreia do Sul, inovação é quase uma religião. O Globo, 09.06.2012, Disponível em: <http://oglobo.globo.com/economia/na-coreia-do-sul-inovacao-quase-umareligiao-5159424>. Acesso em: 09.02.2013.

BERGLÖF, Erik; VON THADDEN, Ernst-Ludwig. Short-term versus long-term interests: capital structure with multiple investors. Quarterly Journal of Economics, vol. 109, n. 4 (Nov., 1994), pp. 1055-1084. Disponível em: <http://www.jstor.org/stable/2118356>. Acesso em: 27.01.2012.

BLACK, Bernard S.; CARVALHO, Antonio Gledson de; SAMPAIO, Joelson Oliveira. The Evolution of Corporate Governance in Brazil, Northwestern University School of Law, Law and Economics Research Paper No. 12-22 (draft November 2012). Disponível em: <http://ssrn.com/abstract=2181039>. Acesso em: 01.02.2013.

BLACK, Bernard S.; GILSON, Ronald J. Does venture capital require an active stock market? $1999 . \quad$ Winter, Disponível em: <http://papers.ssrn.com/paper.taf?abstract_id=219174>. Acesso em: 20.09.2010.

. Venture capital and the structure of capital markets: banks versus stock markets. $\quad 1997 . \quad$ November, Disponível <http://papers.ssrn.com/paper.taf?abstract_id=46909>. Acesso em: 04.08.2009.

BOBBIO, Norberto. Da estrutura à função: novos estudos de teoria do direito. São Paulo: Manole, 2007. 
BOLTON, Patrick; DEWATRIPONT, Mathias. Contract theory. MIT Press, 2005.

BOLTON, Patrick; SCHARFSTEIN, David S. The theory of predation based on agency problems in financial contracting. The American Economic Review, vol. 80, n. 1 (Mar., 1990), pp. 93-106. Disponível em: <http://www.jstor.org/stable/2006736>. Acesso em: 27.01.2012.

BOTAZZI, Laura; DA RIN, Marco; HELLMANN, Thomas. The importance of trust for investment: evidence from venture capital. September, 2010. Disponível em: <http://www.jstor.org/stable/997934>. Acesso em: 27.01.2012.

BULGARELLI, Waldirio. Manual das sociedades anônimas. 9ª Ed., São Paulo: Atlas, 1997.

CAO, Jerry X.; HSU, Po-Hsuan. Patent signaling, entrepreneurial performance, and venture capital financing. September, 2010. Disponível em: <http://papers.ssrn.com/paper.taf?abstract_id=1678809>. Acesso em: 20.09.2010.

CAOUETTE, John B.; ALTMAN, Edward I.; NARAYANAN, Paul. Gestão do risco de crédito. Rio de Janeiro: Qualitimark, 2000.

CHADE, Jamil. Brasil cai em ranking tecnológico global. O Estado de São Paulo. 10.04.2008. Disponível em: < http://www.estadao.com.br/noticias/impresso,brasil-cai-emranking-tecnologico-global,154184,0.htm>. Acesso em: 09.02.2013.

CLARK, Robert C. Corporate law. New York: Aspen Law and Business, 1986.

COASE, Ronald H. The firm, the market, and the law. Chicago: University of Chicago Press, 1990.

COMITÊ DE PRONUNCIAMENTOS CONTÁBEIS. Pronunciamento conceitual básico. Estrutura conceitual para a elaboração e apresentação das demonstrações contábeis. Disponível em: <http://www.cpc.org.br>. Acesso em: 09.09.2011. 
COMPARATO, Fabio K. A natureza da sociedade anônima e a questão da derrogabilidade das regras legais de "quorum" nas assembleias gerais e reuniões do conselho de admi nistração. Revista de Direito Mercantil Industrial Econômico e Financeiro, São Paulo, Ano XVII, v. 27, Nova Série, pp. 89-98, 1978.

COOTER, Robert D.; SCHAEFER, Hans B. The secret of growth is financing secrets: corporate law and growth economics. Journal of Law and Economics 54 (2011): S105S123. Disponível em: <http://works.bepress.com/robert_cooter/166/>. Acesso em: 23.02.2013.

CUMMING, Douglas; JOHAN, Sofia. Information asymmetries, agency costs and venture capital exit outcomes. Venture Capital, an International Journal of Entrepreneurial Finance (2008). Draft (December 2007). Disponível em: <http://papers.ssrn.com/paper.taf?abstract_id=1265947>. Acesso em: 11.03.2011.

DAMODARAN, Aswath. Finanças corporativas - teoria e prática. Porto Alegre: Bookman, $2^{\mathrm{a}}$ ed., 2004.

DAVIS, Morton D. Teoria dos jogos - uma introdução não técnica. Tradução: Leonidas Hezenberg. São Paulo: Cultrix, 1973.

DEWATRIPONT, Mathias; TIROLE, Jean. A theory of debt and equity: diversity of securities and manager-shareholder congruence. Quarterly Journal of Economics, Vol. 109, n. 4 (Nov., 1994), pp. 1027-1054. Disponível em: <http://www.jstor.org/stable/2118355>. Acesso em: 27.01.2012.

DIBVIG, Philip H.; ZENDER, Jaime F. Capital structure and dividend irrelevance with asymmetric information. Review of Financial Studies, n. 4, 1991, pp. 201-219. Disponível em: <http://leeds-faculty.colorado.edu/Zender/papers/Irrelevance.pdf>. Acesso em: 12.04.2012.

EIZIRIK, Nelson; GAAL, Ariadna B.; PARENTE, Flávia; HENRIQUES, Marcus de 
Freitas. Mercado de capitais - regime jurídico. $3^{\mathrm{a}}$. Ed., Rio de Janeiro: Renovar, 2011.

ENRIQUES, Luca. Il conflitto d'interessi nella gestioni delle società per azioni: spunti teorici e profili comparatistici in vista della riforma del diritto societario. Rivista delle Società, Ano 45\% / 2000, pp. 509-561, Mai./Ago. 2000, fascículo $3^{\circ}-4^{\circ}$.

FAMA, Eugene F.; JENSEN, Michael C. Agency problems and residual claims. Journal of Law \& Economics, Vol. XXVI (June 1983). Disponível em: <http://papers.ssrn.com/paper.taf?abstract_id=94032>. Acesso em: 11.03.2011.

FIANI, Ronaldo. Teoria dos jogos. 2a ed., São Paulo: Campus, 2006.

FORTUNA, Eduardo. Mercado financeiro - produtos e serviços. $18^{\mathrm{a}}$ ed., Rio de Janeiro: Qualitymark, 2010.

FRIED, Jesse M.; GANOR, Mira. Agency costs of venture capitalist control in startups. New York University Law Review, Vol. 81, pp. 101-156. Disponível em: <http://ssrn.com/abstract=784610>. Acesso em: 06.10.2012.

FUNDAÇÃO GETÚLIO VARGAS (GVCEPE). A indústria de private equity e venture capital - segundo censo brasileiro. $1^{\text {a }}$ Ed., Março/2011. Disponível em: <http://gvcepe.com/>. Acesso em: 03.04.2012.

FURTADO, Cláudio V. Emissão de ações e valor de mercado da empresa: um estudo de ofertas primárias de ações negociadas em bolsas de valores no Brasil. Tese de Doutorado. São Paulo: EAESP/FGV, 1997.

GINTIS, Herbert. Game theory evolving - A problem-centered introduction to modeling strategic interaction. Princeton: Princeton University Press, 2000.

GOMPERS, Paul A.; KOVNER, Anna; LERNER, Josh; SCHARFSTEIN, David. Skill vs. luck in entrepreneurship and venture capital: evidence from serial entrepreneurs. July, 2006. Disponível em: <http://papers.ssrn.com/paper.taf?abstract_id=933932>. Acesso em: 
20.09.2010.

GOMPERS, Paul A.; LERNER, Josh. The venture capital cycle. $2^{\text {nd }}$ ed., Cambridge: MIT Press, 2006.

GORGA, Érica. Direito societário atual. São Paulo: Ed. Campus, 2013.

GORGA, Érica; PELA, Juliana K. (org.). Estudos avançados de direito empresarial. São Paulo: Ed. Campus, 2013.

GUERREIRO, José A. T. Direito de retirada: um limite ao princípio majoritário na sociedade anônima. Revista de Direito Mercantil, Industrial, Econômico e Financeiro, Ano XLVIII, n. 151/152, pp. 13-21, Jan./Dez. 2009.

Regime jurídico do consórcio. Revista de Direito Mercantil Industrial Econômico e Financeiro, São Paulo, Ano XLIV, v. 138, pp. 202-206, Abr./Jun. 2005.

Sobre a opção de compra de ações. Revista de Direito Mercantil Industrial Econômico e Financeiro, São Paulo, Ano XIX, v. 39, pp. 226-229, Jul./Set. 1980.

HAHN, Robert W. The economics of patent protection: policy implications from the literature. $\quad$ October 2003.20 Disponível em: <www.ssrn.com/paper.taf?abstract_id=467489>. Acesso em: 18.02.2013.

HART, Oliver. Financial contracting. Journal of Economic Literature, vol. 39, N. 4, Dez. 2001, pp. 1079-1100. Disponível em: <http://www.jstor.org/stable/2698520>. Acesso em: 07.09.2010.

HART, Oliver; MOORE, John. A theory of debt based on the inalienability of human capital. The Quarterly Journal of Economics, Vol. 109, No. 4 (Nov., 1994), pp. 841-879. Disponível em: <http://qje.oxfordjournals.org/content/109/4/841>. Acesso em: 27.01.2012. 
HELLMANN, Thomas. The allocation of controls rights in venture capital contracts, RAND Journal of Economics, vol. 29, N. 1 (Spring, 1998), pp. 57-76. Disponível em: <http://www.jstor.org/stable/2555816>. Acesso em: 27.01.2012.

HÖLMSTROM, Bengt. Moral hazard and observability, The Bell Journal of Economics, Vol. 10, No. 1 (Spring, 1979), pp. 74-91. Disponível em: <http://www.jstor.org/stable/3003320>. Acesso em: 28.01.2012.

HURWICZ, Leonid. But who will guard the guardians? May, 1998. Disponível em $<$ http://www.econ.umn.edu/hurwicz>. Acesso em: 15.01.2008.

IHA, Márcio Y. Problemas de agência no relacionamento fundo de capital de risco empreendedor no Brasil: um estudo de caso. Dissertação de Mestrado. São Paulo: Fundação Getúlio Vargas, 2003.

INSEAD BUSINESS SCHOOL; PRICEWATERHOUSECOOPERS. INSEAD $-P w C$ study on private equity - Brazilian private equity: moving centre strategy. 2013. Disponível em: <http://www.pwc.com.br/>. Acesso em: 09.06.2013.

INSTITUTO BRASILEIRO DE GEOGRAFIA E ESTATÍSTICA (IBGE). Pesquisa de inovação tecnológica: 2008. Rio de Janeiro: IBGE, 2010. Disponível em: $<$ http://www.pintec.ibge.gov.br>. Acesso em: 17.02.2013.

IPPOLITO, Richard A. Economics for lawyers. Princeton: Princeton University Press, 2005.

IUDICIBUS, Sergio de; MARTINS, Eliseu; GELBCKE, Ernesto; SANTOS, Ariovaldo dos. Manual de contabilidade societária. São Paulo: Atlas, 2010.

JENSEN, Michael C. Agency costs of free cash flow, corporate finance, and takeovers. American Economic Review, May 1986, Vol. 76, No. 2, pp. 323-329. Disponível em: <http://papers.ssrn.com/paper.taf?abstract_id=99580>. Acesso em: 11.03.2011. 
JENSEN, Michael C.; MECKLING, William H. Theory of the firm: managerial behaviour, agency cost and ownership structure. Journal of Financial Economics, v. 3, n. 4, 1976, pp. 305-360. Disponível em: <http://papers.ssrn.com/sol3/paper.taf?abstract_id=94043>. Acesso em: 15.05.2006.

KAPLAN, Steven N.; STRÖMBERG, Per. Characteristics, contracts, and actions: evidence from venture capitalist. The Journal of Finance, Vol. 59, No. 5 (Oct., 2004), pp. 2177-2210. Disponível em: <http://www.jstor.org/stable/3694821>. Acesso em: 07.02.2011.

Financial contracting theory meets the real world: an empirical analysis of venture capital contracts. The Review of Economic Studies, Vol. 70, No. 2 (Apr., 2003), pp. 281-315. Disponível em: <www.jstor.org/stable/3648635>. Acesso em: 07.09.2010.

Venture capital as principals: contracting, screening and monitoring. American Economic Review, Vol. 91, No. 2, Papers and Proceedings of the Hundred Thirteenth Annual Meeting of the American Economic Association (May, 2001), pp. 426-430. Disponível em: <http://www.jstor.org/stable/2677802>. Acesso em: 19.03.2011.

KNIGHT, Frank H. Risk, uncertainty and profit. 1921. Disponível em: 〈www.econlib.org>. Acesso em: 04.06.2012.

LAMY FILHO, Alfredo; BULHÕES PEDREIRA, José L. A lei das S/A (pressupostos, elaboração, aplicação). Rio de Janeiro: Renovar, 1992.

LAVCA (LATIN AMERICA VENTURE CAPITAL ASSOCIATION). Guia para term sheets de venture capital e private equity, 2012. Disponível em: 〈www.lavca.org〉. Acesso em 19.02.2013.

LAVCA (LATIN AMERICA VENTURE CAPITAL ASSOCIATION). Guia para contratos de venture capital e private equity, 2012. Disponível em: 〈www.lavca.org>. Acesso em 19.02.2013. 
LAVCA (LATIN AMERICA VENTURE CAPITAL ASSOCIATION). The private equity and venture capital environment in Latin America - Scorecard, 2012. Disponível em: <www.lavca.org>. Acesso em 19.02.2013.

LAZZARESCHI NETO, Alfredo S. Lei das sociedades por ações anotada, São Paulo: Saraiva, 2006.

LEÃES, Luiz Gastão P. B. A disciplina do direito de empresa no novo código civil. Revista de Direito Mercantil, Industrial, Econômico e Financeiro, Ano XLI, n. 128, pp. 714, Out.-Dez. 2002.

Exclusão extrajudicial de sócio em sociedade por quotas. Revista de Direito Mercantil, Industrial, Econômico e Financeiro, Ano XXXIV, n. 100, pp. 85-97, Out./Dez. 1995.

LOPES, Alexsandro B. Earnings management and corporate governance: legal and regulatory implications. Revista de Direito Mercantil, Industrial, Econômico e Financeiro, Ano L, Vol. 158, pp. 7-25, 2011.

LOPES, Alexsandro B.; FURTADO, Cláudio V. Private equity na carteira de investimentos das entidades de previdência privada. Revista de Contabilidade e Finanças USP - Especial Atuária. São Paulo, Dez., 2006, pp. 108-126.

MARCONDES MACHADO, Sylvio. Problemas de direito mercantil. São Paulo: Saraiva, 1977. Questões de direito mercantil. São Paulo: Max Limonad, 1970.

MARTELANC, Roy; TRIZI, Juliana S.; PACHECO, André A. S.; PASIN, Rodrigo M. Utilização de metodologias de avaliação de empresas: resultados de uma pesquisa no Brasil. Disponível em: 〈www.ead.fea.usp.br/Semead/8semead/resultado/trabalhosPDF>. Acesso em: 22.06.2009.

MARTINS, Eliseu; IUDÍCIBUS, Sérgio de. Intangível - sua relação contabilidade/direito 
- teoria, estruturas conceituais e normas - problemas fiscais de hoje. In: MOSQUERA, Roberto Quiroga; LOPES, Alexsandro B. (org.). Controvérsias Jurídico-Contábeis (Aproxi mações e Distanciamentos). São Paulo: Dialética, 2011, pp. 69-85.

MELLO FRANCO, Vera H. As sociedades de pessoas na atualidade. Uma visão comparativa crítica. Revista de Direito Mercantil, Industrial, Econômico e Financeiro, Ano L, n. 157, pp. 93-111, Jan./Mar. 2011.

. Contratos - direito civil e empresarial. São Paulo: Ed. Revista dos Tribunais, $3^{\mathrm{a}}$ ed., 2012 .

. Direito empresarial I. $3^{\text {a }}$ Ed., São Paulo: Revista dos Tribunais, 2009.

O triste fim das sociedades limitadas no novo Código Civil. Revista de Direito Mercantil, Industrial, Econômico e Financeiro, Ano XL, n. 123, pp. 81-85, Jul./Set. 2001.

Resolução do vínculo societário em relação ao sócio - reescrevendo antigos temas perante o CC 2002. In: GORGA, Érica; PELA, Juliana K. (org.), Estudos avançados de direito empresarial, Ed. Campus, 2013, pp. 93-110.

MELLO FRANCO, Vera H.; SZTAJN, Rachel. Direito empresarial II. $2^{\text {a }}$ Ed., São Paulo: Revista dos Tribunais, 2009.

MERCURO, Nicholas; MEDEMA, Steven G. Economics and the law. Princeton: Princeton University Press, 1997.

MILLER, Merton H. Leverage. In ADLER, Barry E. Foundations of bankruptcy law. New York: Foundation Press, 2005.

MINARDI, Andrea M. A. F. Teoria das opções aplicada a projetos de investimento. Revista de Administração de Empresas (RAE), V. 40, n. 2, pp. 74-79, Abr./Jun. 2000.

MODIGLIANI, Franco; MILLER; Merton H. Corporate income taxes and the cost of 
capital: a correction. American Economic Review, n. 53, June 1963, pp. 433-443.

The costs of capital, corporate finance, and the theory of investment. American Economic Review, n. 48, June/1958, pp. 261-297.

MOSQUERA, Roberto Quiroga; FREITAS, Rodrigo de. Aspectos polêmicos do ágio na aquisição de investimento: (i) rentabilidade futura e (ii) ágio interno. In: MOSQUERA, Roberto Quiroga; LOPES, Alexsandro B. (org.). Controvérsias Jurídico-Contábeis (Aproxi mações e Distanciamentos). Vol. 2, São Paulo: Dialética, 2011, pp. 248-280.

MYERS, Stewart; MAJLUF, Nicholas. Corporate financing and investment decisions when firms have information the investors do not have. National Bureau of Economic Research. Working Paper 1396 (July 1984). Disponível em: <http://www.nber.org/papers>. Acesso em: 27.01.2012.

NERY JÚNIOR, Nelson; NERY, Rosa M. de A. Código civil comentado. $7^{\mathrm{a}}$ ed., São Paulo: Revista dos Tribunais, 2009.

NORTH, Douglass C. Institutions, institutional change and economic performance. New York: Cambridge University Press, 2002.

OFFA, Luiz F. W. Contratos financeiros entre empreendedores e gestores de fundos de private equity e venture capital: teoria e realidade no caso brasileiro. Dissertação de Mestrado. São Paulo: Fundação Getúlio Vargas, 2005.

PASIN, Rodrigo M.; MARTELANC, Roy; SOUZA, Almir F. A flexibilidade do processo decisório e o valor da opção de adiamento. VI SEMEAD - Seminários em Administração FEA-USP. (03, 2003). Disponível em: <http://www.ead.fea.usp.br/Semead/6semead/>. Acesso em: 22.06.2009.

PELA, Juliana K. O contrato preliminar. Revista de Direito Mercantil Industrial Econômico e Financeiro, São Paulo, Ano XLII, v. 130, pp. 230-235, Abr./Jun. 2003. 
PENTEADO, Mauro R. Associações voluntárias de empresas - uma análise da legislação no país e no exterior. Revista de Direito Mercantil Industrial Econômico e Financeiro, São Paulo, Ano XXII, v. 52, pp. 44-63, Out./Dez. 1983.

. Extinção de sociedades no Código Civil de 2002. In: Princípios do novo Código Civil Brasileiro e outros temas - homenagem a Tullio Ascarelli. JUNQUEIRA DE

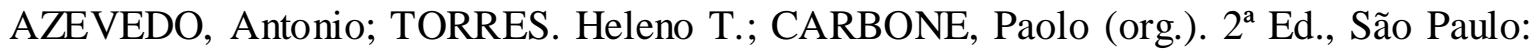
Quartier Latin, 2010, pp. 451-489.

- Formação de contrato preliminar suscetível de adjudicação compulsória. Revista de Direito Mercantil, Industrial, Econômico e Financeiro, Ano XIX, n. 39, pp. 136-183, Jul./Set. 1980.

PINDYCK, Robert S.; RUBINFELD, Daniel L. Microeconomia. São Paulo: Pearson Prentice Hall, 6a . Ed., 2006.

PRICEWATERHOUSECOOPERS. Doing business and investing in Brazil, São Paulo, 2013. Disponível em: <http://www.pwc.com.br/>. Acesso em: 09.06.2013.

PROCURADORIA GERAL DA FAZENDA NACIONAL. Isenção fiscal para investidor estrangeiro poderá acabar. Disponível em: <http://www.pgfn.fazenda.gov.br/noticias_importadas/>. Acesso em: 16.02.2013.

ROPPO, Vincenzo. Il contrato. Milano: Ed. Giuffrè, 2001.

SANDRONI, Paulo. Dicionário de Economia. $3^{\text {a }}$ ed., São Paulo: Best Seller, 1994.

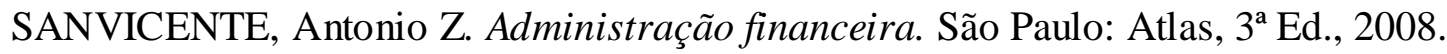
Derivativos. São Paulo: Publifolha, 2003.

SECURATO, José R. Cálculo financeiro das tesourarias. $2^{\mathrm{a}}$ ed., São Paulo: Saint Paul Institute of Finance Editora, 2003. 
SILVEIRA, Newton. Propriedade intelectual: propriedade industrial, direito de autor, software, cultivares. $3^{\text {a }}$ ed., São Paulo: Manole, 2005.

SOUZA JR, Francisco Satiro de; PITOMBO, Antonio Sérgio A de Moraes (coord.). Comentários à lei de recuperação de empresas e falência. $1^{a}$ ed., São Paulo: Revista dos Tribunais, 2005.

STANGHELLINI, Lorenzo. Crisi di impresa fra diritto ed economia - le procedure di insolvenza. Bologna: Il Mulino, 2007.

SZTAJN, Rachel. A disciplina das sociedades no código civil brasileiro. In: Princípios do novo Código Civil brasileiro e outros temas - homenagem a Tullio Ascarelli. JUNQUEIRA DE AZEVEDO, Antonio; TORRES. Heleno T.; CARBONE, Paolo (org.).

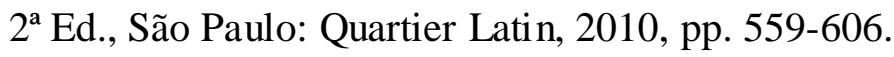

Associações e sociedades. Revista de Direito Mercantil, Industrial, Econômico e Financeiro, Ano XLI, n. 128, pp. 15-26, Out./Dez. 2002.

Direito de recesso. Tese de doutorado. São Paulo: Faculdade de Direito da Universidade de São Paulo. 1982.

Futuros e swaps - uma visão jurídica. São Paulo: Cultural Paulista, 1999.

Quotas de fundos imobiliários - novo valor mobiliário. Revista de Direito Mercantil Industrial Econômico e Financeiro, São Paulo, Ano XXXIII, v. 93, pp. 104-108, Jan./Mar. 1994.

Sobre a natureza jurídica das opções negociadas em bolsas. Revista de Direito Mercantil Industrial Econômico e Financeiro, São Paulo, Ano XXXVI, v. 105, pp. 53-69, Jan./Mar. 1997.

SZTAJN, Rachel; VERÇOSA, Haroldo M. D. A incompletude do contrato de sociedade. 
Revista de Direito Mercantil, Industrial, Econômico e Financeiro, Ano XLII, n. 131, pp. 720, Jul./Set. 2003.

TOMASETTI JUNIOR, Alcides. Execução do contrato preliminar. Tese de doutorado. São Paulo: Faculdade de Direito da Universidade de São Paulo. 1982.

TOWSEND, Robert M. Optimal contracts and competitive markets with costly state verification. Journal of Economic Theory, Vol. 21, N. 2 (Oct., 1979), pp. 265-293. Disponível em: <http://www.robertmtownsend.net>. Acesso em: 01.02.2012.

TVERSKY, Amos; KAHNEMANN, Daniel. Prospect theory: an analysis of decision under risk. Econometrica, Vol. 47, n. 2, pp. 263-292, Mar. 1979.

Rational choice and the framing of decisions. Journal of Business, Vol. 59, n. 4, Part 2: The Behavioral Foundations of Economic Theory, pp. S251-278, October 1986.

VERÇOSA, Haroldo M. D. Curso de direito comercial. São Paulo: Malheiros, vol. 1, 2004; vol. 2, $2^{\mathrm{a}}$ ed., 2006; vol. 3, 2ª ed., 2011; vol. 4, Tomo I, 2011.

Os contratos inominados e o novo código civil. Revista de Direito Mercantil, Industrial, Econômico e Financeiro, Ano XLI, n. 126, pp. 31-36, Abr./Jun. 2002.

VERÇOSA, Haroldo M. D.; BARROS, Zanon P. Breve estudo comparativo esquemático das sociedades limitadas no direito anterior e no novo Código Civil. Revista de Direito Mercantil, Industrial, Econômico e Financeiro, Ano XLII, n. 130, pp. 69-93, Abr./Jun. 2003.

WALD, Arnoldo. Da natureza jurídica do fundo imobiliário. Revista de Direito Mercantil, Industrial, Econômico e Financeiro, Ano XXIX, n. 80, pp. 15-23, Out./Dez. 1990.

WILLIAMSON, Oliver E. The economic institutions of capitalism. New York: Free Press, 1987. 
WORLD ECONOMIC FORUM. The Global Information Technology Report 2012. Disponível em: <http://www.weforum.org/issues/global-informationtechnology/index.html>. Acesso em: 09.02.2013.

WORLD INTELLECTUAL PROPERTY ORGANIZATION (WIPO). WIPO IP facts and $\begin{array}{lllll}\text { figures } & - & 2011 . & \text { Disponível em: }\end{array}$ <www.wipo.int/freepublications/en/statistics/943/wipo_pub_943_2011.pdf>. Acesso em: 18.02.2013.

WORLD INTELLECTUAL PROPERTY ORGANIZATION (WIPO). Indicators - 2012 Edition. Disponível em: <www.wipo.int/export/sites/www/freepublications/en/intproperty/941/wipo_pub_941_201 2.pdf>. Acesso em: 18.02.2013.

ZYLBERSTAJN, Decio; SZTAJN, Rachel. (coord.) Direito e economia - análise econômica do direito e das organizações. São Paulo: Campus, 2005. 


\section{ANEXOS}

\section{VI.1. Etapas do Negócio de Venture Capital}

\section{Visão geral}

O empreendimento de venture capital desenvolve-se em três etapas consecutivas e interativas: contratação; monitoramento; desinvestimento.

$\mathrm{Na}$ etapa de contratação ocorre a negociação do contrato, que pode ser precedida pelas tratativas e investigação sobre a qualidade do negócio. Na etapa de monitoramento ocorre o acompanhamento do progresso das atividades, a avaliação dos resultados parciais e a tomada de decisão sobre a continuidade ou interrupção do empreendimento. Na etapa de desinvestimento ocorre a venda do negócio.

Os projetos são mais bem controlados quando subdivididos em etapas de menor duração e complexidade, nas quais são fornecidos apenas recursos suficientes para executar a etapa em curso. Ao longo da execução do projeto sempre haverá alocação gradual de recursos e monitoramento das atividades e resultados parciais, que servem para decidir por manter, ou não, o investimento na etapa seguinte. Em caso positivo nova etapa é iniciada e são desenvolvidas as atividades planejadas. Caso contrário há interrupção do projeto.

O investimento gradual modula a assunção de riscos pelo investidor, evitando que projetos promissores recebam recursos insuficientes ou alocação excessiva de recursos em negócios que apresentem desempenho insatisfatório. A abordagem serve para minimizar perdas, interrompendo projeto ineficiente, estratégia conhecida como stop loss. A estratégia também visa a manter o empreendedor comprometido com a execução do projeto, pois os resultados parciais alcançados na etapa em curso afetam a decisão de disponibilizar recursos para executar a etapa seguinte.

O equilíbrio contratual é mais facilmente alcançado se houver subdivisão do projeto em etapas menores, permitindo-se a renegociação do projeto ao final de cada 
etapa. Dependendo das características do negócio, a estruturação pode variar. Por exemplo, o projeto pode ter as seguintes etapas: 1) estruturação e desenvolvimento da ideia, seus componentes, insumos e processo produtivo; 2) fabricação dos produtos; 3 ) testes de mercado e pré-produção industrial; 4) produção e comercialização em larga escala; 5) venda do negócio.

O sucesso é medido pela relação risco-retorno sobre o investimento, isto é, comparação entre a variação do risco e a variação do retorno esperado. Nem sempre o aumento do risco de um empreendimento implica em aumento do retorno. Da mesma forma, a redução do retorno não implica necessariamente em redução do risco. A análise de risco-retorno permite responder à seguinte pergunta: quanto se deve investir e quais riscos se devem assumir para obter determinado nível de retorno ${ }^{218,219}$.

Em cada etapa do projeto são estabelecidos eventos para avaliar o progresso e decidir se haverá próxima etapa. Se o empreendimento é interrompido, o investidor minimi za prejuízos e perdas futuras, retirando-se do negócio. Se o projeto continua, há fornecimento de novos recursos para a etapa seguinte.

O aporte de recursos pode ser realizado no decorrer da etapa em curso, isto é, depende de metas específicas de desempenho aferidas nessa etapa. $\mathrm{O}$ aporte também pode ser realizado no intervalo entre duas etapas consecutivas, o que implica em avaliação do desempenho alcançado ao final da etapa encerrada.

\section{Contratação}

O investidor em venture capital deve desempenhar diversas funções críticas: 1) manter relacionamento com outros investidores; 2) realizar, periodicamente, a captação de recursos e organização dos fundos para investimento; 3) avaliar propostas de

${ }^{218}$ PINDYCK, Robert S.; RUBINFELD, Daniel L. Microeconomia. São Paulo: Pearson - Prentice Hall, $6^{\mathrm{a}}$. Ed., 2006, pp. 146-149.

${ }^{219}$ FORTUNA exemplifica: a relação risco-retorno pode ser medida pelo Índice de Sharpe (Índice de Volatilidade ou Î́ndice de Eficiência), que compara os riscos e o retorno do projeto com um referencial de eficiência esperada, que pode ser um índice de mercado (por exemplo, o IGPM) ou definido pelas partes. A comparação entre o índice alcançado e o esperado permite avaliar se o investimento que apresenta maior retorno será, ou não, a melhor escolha, dado o nível de risco associado. (FORTUNA, Eduardo. Mercado financeiro - produtos e serviços. $18^{\mathrm{a}}$ ed., Rio de Janeiro: Qualitymark, 2010, pp. 551-552). 
negócio e realizar due diligence; 4) realizar aporte de recursos nos projetos; 5) acompanhar e participar da administração do negócio; 6) decidir o momento ideal e a forma de organização da operação de venda ${ }^{220}$.

O investidor é afetado por incentivos econômicos e reputacionais. O principal incentivo econômico é a rentabilidade do negócio, ajustada ao risco que pretende tomar. O retorno é demonstrado no momento do desinvestimento e serve para sinalizar sua reputação ao mercado. O principal incentivo reputacional é o sucesso do projeto e da operação de venda do negócio, que sinalizam a competência do administrador e a qualidade do empreendimento.

O negócio de venture capital apresenta uma ou mais características que o tornam atrativo para os investidores: 1) alto potencial de crescimento e lucratividade; 2) participação em mercados inovadores; 3) plano de negócios potencialmente sólido; 4) quadro de administradores com reputação reconhecida pelo mercado; 5) empreendedor competente e equipe técnica qualificada, detentores de conhecimento relevante sobre as tecnologias empregadas no projeto; 6) existência e bens e direitos imateriais; 7) dificuldade para obter financiamento bancário.

O financiamento por meio de venture capital é indicado para projetos que necessitam de recursos e não dispõem de ativos para oferecer em garantia nem apresentam os requisitos exigidos pelo mercado para obtenção de empréstimos.

A etapa de contratação do investimento inicia-se com a aproximação entre empreendedor e investidor, a originação. De acordo com o Segundo Censo Brasileiro da Indústria de Private Equity e Venture Capital, realizado pela Fundação Getúlio Vargas (GVCEPE), as propostas de investimento podem ser classificadas em três modalidades: prospecção proprietária, indicação de terceiros e candidatura espontânea. $\mathrm{Na}$ primeira, o investidor prospecta ativamente os candidatos a receber recursos. $\mathrm{Na}$

${ }^{220}$ GOMPERS, Paul A.; LERNER, Josh. The venture capital cycle. $2^{\text {nd }}$ ed., Cambridge: MIT Press, 2006, pp. $7-8$. 
segunda, a aproxi mação é feita por intermediários. Na terceira, o empreendedor procura diretamente o investidor e propõe o negócio ${ }^{221}$.

A informação trocada durante as tratativas pré-contratuais é confidencial e de difícil verificação empírica. Normalmente as partes celebram acordos de confidencialidade, acordos de segredo e cartas de intenção de negociação ${ }^{222}$, visando a evitar a revelação de informação a terceiros.

Importante sinalização das intenções das partes é a capacidade e disposição para incorrer em custos durante a etapa de negociação ${ }^{223}$. O procedimento de investigação preliminar pode durar vários meses e consumir recursos significativos, normalmente pagos pelo empreendedor e não reembolsados pelo investidor. É frequente que o empreendedor tenha que arcar com os custos de assessoria jurídica, consultoria, registros de documentos em órgãos públicos, etc. ${ }^{224}$.

O investidor avalia a rentabilidade potencial do negócio como uma proposta de investimento, comparando-a com outras opções de alocação de recursos. O empreendedor precisa demonstrar que o projeto será capaz de gerar o retorno esperado pelo investidor, que deverá ser superior às alternativas. A projeção de retorno potencial do negócio e o grau de risco esperado são as bases para tomada de decisão, usadas para definir os indicadores de desempenho do negócio e a remuneração das partes. A avaliação inicial serve para determinar o preço de compra da participação e toma por base a "tese de investimento" do investidor, ou seja, os critérios unilateralmente estabelecidos para aceitar ou rejeitar as propostas de negócio.

\footnotetext{
${ }^{221}$ Fundação Getúlio Vargas (GVCEPE). A indústria de private equity e venture capital - segundo censo brasileiro. $1^{\text {a }}$ Ed., Março/2011. Disponível em: <http://gvcepe.com/>. Acesso em: 03.04.2012, pp. 163-167.

${ }^{222}$ BASSO, Maristela. Contratos internacionais do comércio. $2^{\mathrm{a}}$ Ed., Porto Alegre: Livraria do Advogado Editora, 1998, pp. 152-155.

${ }^{223}$ IPPOLITO apresenta exemplo de sinalização: a disposição de um candidato a emprego em incorrer em custos de viagem e dispêndio de tempo para participar de entrevistas de seleção, que sinaliza o interesse em participar do processo seletivo. (IPPOLITO, Richard A. Economics for lawyers. Princeton: Princeton University Press, 2005, pp. 390-393).

${ }^{224}$ LAVCA (Latin America Venture Capital Association). Guia para term sheets de venture capital e private equity, 2012. Disponível em: 〈www.lavca.org>. Acesso em 19.02.2013, p. 4.
} 
Os investidores utilizam regras rígidas para seleção de propostas, a saber: 1) tipo de empreendedor, se novo ou já previamente estabelecido no mercado; 2) ramo de negócio do empreendimento, que deve ser compatível com a área de especialidade do investidor; 3) viabilidade de aporte de capital internacional ou admissão de sócio estrangeiro no negócio; 4) montante e forma de alocação do valor requerido para desenvolver o projeto; 5) expectativa de risco e retorno sobre o investimento; 6) nível de envolvimento dos sócios na administração do negócio; 7) qualidade e reputação dos administradores; 8) competência da equipe técnica; 9) direitos de propriedade imaterial sobre os ativos produzidos; 10) nível percebido de informalidade do negócio e do ambiente institucional no qual o projeto está inserido; 11) administração "familiar" ou "profissional" do negócio; 12) proximidade (distância geográfica) entre o empreendedor e o investidor; 13) existência de incentivos fiscais ${ }^{225}$.

Como as regras de avaliação definidas pelos fundos de venture capital são rígidas, alguns empreendedores podem preferir obter recursos diretamente de "investidores-anjos", pessoas naturais ou jurídicas que possuem experiência, recursos e interesse em investir quantia menos significativa de recursos em projetos de menor porte em fase embrionária ${ }^{226}$.

Geralmente, os investidores organizam-se sob a forma de fundos de investimento e os negócios-alvo organizam-se sob a forma de sociedades fechadas. Normalmente, as partes não possuem relacionamento prévio ${ }^{227}$, sendo possível que venham a ocorrer erros de avaliação pelo investidor, se o risco e a rentabilidade esperada para o projeto forem distintos das informações apresentadas pelo empreendedor. Do ponto de vista do empreendedor o erro de avaliação também pode

\footnotetext{
${ }^{225}$ Fundação Getúlio Vargas (GVCEPE). A indústria de private equity e venture capital - segundo censo brasileiro. $1^{\text {a }}$ Ed., Março/2011. Disponível em: <http://gvcepe.com/>. Acesso em: 03.04.2012, pp. 167-168; GOMPERS, Paul A.; LERNER, Josh. The venture capital cycle. $2^{\text {nd }}$ ed., Cambridge: MIT Press, 2006, pp. $157-169$.

${ }^{226}$ A respeito dos investidores-anjos, ver: Fundação Getúlio Vargas (GVCEPE). A indústria de private equity e venture capital - segundo censo brasileiro. $1^{\mathrm{a}}$ Ed., Março/2011. Disponível em: 〈http://gvcepe.com/>. Acesso em: 03.04.2012, pp. 157-159.

${ }^{227}$ Quando há relacionamento prévio, há maiores possibilidades de cooperação para redução de assimetrias informacionais e menor oportunismo, pois uma das partes já tem conhecimento sobre o comportamento da outra. Ainda assim, os contratos devem prever sanções críveis e proporcionais ao dano causado, para obrigar a parte a agir no interesse do negócio, evitando o oportunismo. (SZTAJN, Rachel. Direito e Economia dos contratos. Os conceitos fundamentais. In: VERÇOSA, Haroldo M. D. Curso de direito comercial. São Paulo: Malheiros, Vol. 4, 2011, pp. 86-87).
} 
ocorrer, pois as habilidades demonstradas pelo investidor podem ser diferentes das esperadas, como, por exemplo, a capacidade de administração do negócio, experiência e conhecimento do mercado.

Durante a etapa de contratação, é essencial sinalizar a qualidade do negócio, que pode ser observada na oferta de investimentos e em cláusulas contratuais estipuladas entre as partes. $\mathrm{O}$ empreendedor pode sinalizar sua capacidade e a qualidade do projeto condicionando parcela significativa da remuneração ao desempenho do negócio, isto é, assumindo parcela maior de remuneração variável, calculada em função do desempenho do projeto.

O mesmo pode ocorrer com o investidor. Ele pode sinalizar sua reputação e habilidades assumindo maior parcela de remuneração variável. Investidores ainda não estabelecidos no mercado preferem construir reputação selecionando bons projetos e agregando-lhes maior valor, mesmo que a remuneração seja menor que a oferecida aos administradores com reputação consolidada. Depois que a reputação estiver estabelecida, isto é, após a execução de alguns projetos bem sucedidos, a relação esforço-remuneração tende a se aproximar de padrões de mercado. Os incentivos reputacionais têm a ver com problemas de sinalização quando há informação assimétrica, pois a capacidade de uma das partes é desconhecida pela outra e esse conhecimento somente será construído ao longo do desenvolvimento do projeto ${ }^{228}$.

Tanto o investidor quanto o empreendedor podem utilizar recursos próprios diretamente no negócio, sinalizando à outra parte que o projeto é viável. Do ponto de vista do investidor, a atitude também denota suas habilidades de administrador. Do ponto de vista do empreendedor, o investimento de recursos próprios nos estágios iniciais sinaliza que ele acredita na viabilidade do empreendimento. Serve também para

\footnotetext{
${ }^{228}$ GOMPERS e LERNER explicam que, em geral, investidores ainda não estabelecidos aceitam menor remuneração fixa e maior remuneração variável, ao passo que investidores com reputação já constituída negociam maior remuneração total e parcela relativamente maior de remuneração variável. O desempenho do negócio sinaliza a qualidade do administrador e conduz ao interesse de outros investidores em novas captações de recursos oferecidas pelo mesmo investidor. Administradores mais eficientes tendem a constituir fundos maiores e com maior recorrência que os menos eficientes, ao menos enquanto os fundos mantiverem em seus quadros de pessoal os mesmos sócios. De certa maneira, a reputação do fundo é, ao menos em parte, constituída pela reputação individual de seus sócios-administradores. (GOMPERS, Paul A.; LERNER, Josh. The venture capital cycle. $2^{\text {nd }}$ ed., Cambridge: MIT Press, 2006, pp. 30-31; 56-57; 98; 114-115).
} 
tentar reduzir o preço cobrado pelo investidor, ao demonstrar, antecipadamente, que o negócio tem nível de risco menor que o esperado.

A formalização da etapa de contratação é realizada nos term sheets, que são acordos estabelecidos por tempo determi nado, porém com possibilidade de extensão ou renovação, contendo as condições requeridas pelos investidores para realização da avaliação (due diligence) e futura contratação do negócio ${ }^{229}$.

O term sheet pode conter cláusula de sigilo e exclusividade, inviabilizando a apresentação da proposta a outros investidores durante a vi gência do contrato.

Após a conclusão do contrato, inicia-se a due diligence para identificar e avaliar a qualidade e os riscos do negócio, e revelar informação que sirva para modificar ou confirmar a expectativa de risco-retorno do investidor. Os resultados da atividade influenciam a decisão de investimento, preço, prazo e demais condições do negócio.

Entretanto, diversos negócios embrionários são constituídos sem a realização da due diligence, devido à dificuldade em avaliar os riscos do empreendimento e comparálos com alguma referência de mercado. Nesses casos, os custos da due diligence podem superar os benefícios obtidos com a revelação de informação.

$\mathrm{Na}$ etapa de contratação são negociados acordos complementares para estabelecer as condições para conclusão do contrato definitivo. Em geral, são negociadas as seguintes minutas: 1) contrato de subscrição ou compra e venda de participação societária do negócio; 2) acordos de acionistas; 3) esboço de contrato ou estatuto social para condução do empreendimento. A forma jurídica depende do tipo contratual escolhido para desenvolver o empreendimento.

As propostas pré-selecionadas pelo investidor são avaliadas do ponto de vista mercadológico, tecnológico, jurídico, contábil e econômico-financeiro, comparadas com a "tese de investimento" do investidor e sua percepção sobre o risco-retorno

${ }^{229}$ LAVCA (Latin America Venture Capital Association). Guia para term sheets de venture capital e private equity, 2012. Disponível em: 〈www.lavca.org〉. Acesso em 19.02.2013, p. 5. 
esperado para o projeto. O objetivo da avaliação é a revelação de informação sobre o negócio, não apresentada espontaneamente pelo empreendedor, e sua comparação com as expectativas do investidor ${ }^{230}$.

Ao final da atividade de due diligence, as partes negociam os termos contratuais finais que dispõem sobre os direitos, obrigações, riscos e retornos esperados. Especial atenção é dada à definição de cláusulas contratuais que estabeleçam o investimento gradual dos recursos, renegociação periódica das bases do negócio e condições para interrupção do investimento. Também são discutidas regras para deliberação, decisão e administração do negócio em cada etapa. A decisão sobre a aprovação do negócio e conclusão dos contratos é tomada diretamente pelo investidor que, no caso dos fundos de investimento, é representado pelo Comitê de Investimentos ou por seus administradores, por delegação, conforme estabeleça o regulamento interno do fundo ${ }^{231}$.

A avaliação do negócio é obtida com a due diligence e serve para definir as bases do contrato definitivo, a participação de cada sócio e a distribuição esperada de riscos e retorno. A avaliação interessa a ambas as partes, havendo incentivos para adoção de comportamentos oportunistas que permitam influenciar o cálculo do valor.

Podem ser usados diversos métodos de avaliação, porém todos apresentam algum grau de subjetividade, especialmente em negócios de venture capital, porque há pouca ou nenhuma informação de mercado que sirva de referência para comparação com as fornecidas pelo empreendedor ou obtidas durante o procedimento de due diligence $e^{232}$.

Exemplo de avaliação é o "valor presente de saída", no qual são estimados, a valor presente, o lucro futuro do negócio e a relação preço-lucro da participação societária, que são comparados com outras sociedades do mesmo mercado e setor de atividade. Outro método, a avaliação por múltiplos, usada quando há referências de

\footnotetext{
${ }^{230}$ Fundação Getúlio Vargas (GVCEPE). A indústria de private equity e venture capital - segundo censo brasileiro. $1^{\text {a }}$ Ed., Março/2011. Disponível em: <http://gvcepe.com/>. Acesso em: 03.04.2012, pp. 169-173.

${ }^{231}$ Fundação Getúlio Vargas (GVCEPE). A indústria de private equity e venture capital - segundo censo brasileiro. $1^{\text {a }}$ Ed., Março/2011. Disponível em: <http://gvcepe.com/>. Acesso em: 03.04.2012, pp. 174-179.

${ }^{232}$ Formas e métodos de avaliação brevemente descritos no Anexo VI.3.
} 
mercado, é calculada em função da estimativa de ganhos futuros do negócio, isto é, da proporção entre lucratividade e geração de fluxo de caixa do projeto, à qual é aplicado um fator multiplicador ${ }^{233}$.

Na etapa de contratação também são discutidos os percentuais de retorno sobre o investimento e a parcela de controle que o empreendedor está disposto a ceder em troca dos recursos obtidos. A negociação toma a forma de jogo não cooperativo ${ }^{234} \mathrm{de}$ informação assimétrica, imperfeita e incompleta ${ }^{235}$, no qual as principais informações são a avaliação do investimento e a expectativa de risco-retorno. Durante a atividade de avaliação as partes procuram calcular o valor do investimento tentando obter a maior parcela de retorno sobre o negócio, com a menor assunção de riscos individuais. Da avaliação resultam valores de referência para negociar as participações no projeto.

Normalmente, negócios de venture capital são estruturados sob a forma de sociedades empresárias fechadas cujas participações no capital social não são negociadas no mercado durante o desenvolvimento do empreendimento. Essa forma de organização serve para evitar ou minimizar as trocas de comando do negócio ou o abandono prematuro do projeto pelas partes. $\mathrm{O}$ investidor normalmente exige o direito de eleger conselheiros, nomear administradores e influenciar decisões relevantes, retendo o direito de renovação do investimento ao final de cada etapa.

\footnotetext{
${ }^{233}$ Exemplos de métodos indicados por: Fundação Getúlio Vargas (GVCEPE). A indústria de private equitye venture capital - segundo censo brasileiro. $1^{\text {a }}$ Ed., Março/2011. Disponível em: 〈http://gvcepe.com/>. Acesso em: 03.04.2012, pp. 179-180; DAMODARAN, Aswath. Finanças corporativas - teoria e prática. Porto Alegre: Bookman, $2^{\text {a }}$ Ed., 2004, pp. 630-636; MARTELANC, Roy; TRIZI, Juliana S.; PACHECO, André A. S.; PASIN, Rodrigo M. Utilização de metodologias de avaliação de empresas: resultados de uma pesquisa no Brasil. Disponível em: <www.ead.fea.usp.br/Semead/8semead/resultado/trabalhosPDF >. Acesso em: 22.06.2009.

${ }^{234}$ No jogo cooperativo os jogadores podem coordenar estratégias, impossível quando o jogo é não cooperativo (PINDYCK, Robert S.; RUBINFELD, Daniel L. Microeconomia. São Paulo: Pearson - Prentice Hall, ${ }^{\text {a }}$. Ed., 2006, pp. 408-409). Para FIANI, jogo não cooperativo é aquele no qual os jogadores não podem estabelecer compromissos mútuos com garantia de cumprimento das obrigações assumidas. (FIANI, Ronaldo. Teoria dos jogos. $2^{\mathrm{a}}$ ed., São Paulo: Campus, 2006, p. 111). A cooperação pode se dar antes do jogo (coordenação de estratégias) ou durante o jogo (acordos entre os jogadores para di vidir ganhos e incentivar a cooperação, chamados de side payments). Se houver coalizão entre os jogadores, há jogo cooperativo entre os membros que a compõem e jogo não cooperativo entre a coalizão e os demais jogadores. (DAVIS, Morton D. Teoria dos jogos - uma introdução não técnica. Tradução: Leonidas Hezenberg. São Paulo: Cultrix, 1973, pp. 90-104).

${ }^{235}$ A informação é imperfeita (incompleta) quando, ao realizar a escolha, o jogador não conhece a escolha dos demais jogadores. (DAVIS, Morton D. Op.cit., pp. 30-31). FIANI define informação completa como aquela na qual todos os agentes conhecem as preferências de todos os demais, sendo viável tentar estabelecer acordos ou contratos que alinhem os incentivos para todos. (FIANI, Ronaldo. Op.cit., pp. 370-371; DAVIS, Morton D. Op.cit., p. 89).
} 
Devido ao alto grau de risco do empreendimento, a negociação que precede a contratação definitiva é atividade complexa e onerosa, e toma a forma de um jogo sequencial no qual o empreendedor faz uma proposta de investimento que é analisada pelo investidor, resultando em uma contraproposta que, se for aceita pelo empreendedor, implica na conclusão dos contratos e no início do desenvolvimento das atividades.

A negociação entre as partes pode ser analisada a partir do conceito de "opções". SANVICENTE define "opção" como um direito, e não uma obrigação, de compra ou de venda de determinado objeto, por um preço prefixado, até determinada data. $\mathrm{Na}$ opção de compra, o titular do direito paga o preço e retém o direito de receber o ativo objeto da opção. Na opção de venda, o titular conserva o direito de receber o preço para, então, transferir o ativo-objeto a outro interessado ${ }^{236}$.

De acordo com SZTAJN, "opção" é gênero de negócio jurídico que abarca diversas espécies, como, por exemplo, bônus de subscrição de ações (artigo 75 da lei acionária) e opções negociadas em bolsa de valores. O termo "opção" indica um direito de preferência, concedido unilateralmente a terceiro, sobre determinado negócio mediante prazo e condições preestabelecidos ${ }^{237}$. A opção implica em declaração unilateral de vontade ${ }^{238}$, irrevogável e vinculante enquanto durarem as condições autoimpostas na declaração, por meio da qual se oferece a terceiros, em condições predeterminadas, a contratação do negócio subjacente à opção ${ }^{239,240}$.

\footnotetext{
${ }^{236}$ SANVICENTE, Antonio Z. Derivativos, São Paulo: Publifolha, 2003, p. 16.

${ }^{237} \mathrm{O}$ bônus de subscrição atribui ao acionista o direito de subscrever ações de emissão primária da companhia, ao passo que as opções negociadas em bolsa referem-se a ações negociadas no mercado secundário. (SZTAJN, Rachel. Sobre a natureza jurídica das opções negociadas em bolsas. Revista de Direito Mercantil Industrial Econômico e Financeiro, São Paulo, Ano XXXVI, v. 105, Jan./Mar. 1997, p. 53).

${ }^{238}$ Parte da doutrina entende que as opções são um tipo de contrato bilateral de comprae venda a termo, não uma declaração unilateral de vontade. Preferimos a segunda solução, uma vez que a eficácia do negócio não depende de manifestação de vontade das partes para que haja conclusão do contrato, mas de simples declaração da parte emissora da opção. (MELLO FRANCO, Vera H.; SZTAJN, Rachel. Direito empresarial

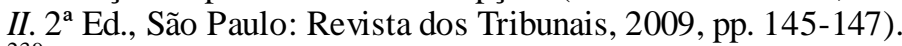

${ }^{239}$ SZTAJN, Rachel. Op.cit., pp. 54; 65-67.

${ }^{240}$ GUERREIRO argumenta que tanto na opção de compra de ações em tesouraria quanto na opção para subscrição de ações novas está presente a promessa unilateral de contratar, por parte da companhia. O exercício da opção representa a execução da promessa, materializando-se na celebração do contrato. Entende ainda que a compra ou a subscrição de ações têm, ambas, caráter contratual, que falta à opção, pois, nesta, não há obrigação correspectiva dos beneficiários como contrapartida ao benefício oferecido pela companhia.
} 
Projetos de venture capital podem ser entendidos como "opções reais" da seguinte maneira: 1) o projeto, que é o ativo-objeto da opção, tem baixa liquidez e não pode ser facilmente negociado no mercado enquanto estiver em desenvolvimento; 2) o projeto é de longa duração; 3) a opção tem valor somente se for exercida até o vencimento $^{241}$. Essas características facilitam a decisão de postergar, expandir ou abandonar os projetos ${ }^{242,243}$, essenciais para a modulação de riscos assumidos pelos contratantes.

$\mathrm{Na}$ contratação de negócios de venture capital, há duas opções distintas e contrapostas, uma emitida pelo empreendedor e outra pelo investidor, com intervalo de tempo entre ambas, relativas ao projeto subjacente à opção.

A primeira "opção" declara os termos propostos pelo empreendedor que fica vinculado à aceitação pelo investidor, no prazo e nas condições definidas. Trata-se de "opção de venda" de participação no negócio, em favor do investidor e oferecida durante as negociações preliminares, com validade até o final do procedimento de due diligence.

(GUERREIRO, José A. T. Sobre a opção de compra de ações. Revista de Direito Mercantil Industrial Econômico e Financeiro, São Paulo, Ano XIX, v. 39, Jul./Set. 1980, pp. 228-229).

${ }^{241}$ DAMODARAN, Aswath. Finanças corporativas - teoria e prática. Porto Alegre: Bookman, $2^{\mathrm{a}}$ Ed., 2004, pp. $718 ; 731$.

${ }^{242}$ MARTELANC, Roy; TRIZI, Juliana S.; PACHECO, André A. S.; PASIN, Rodrigo M. Utilização de metodologias de avaliação de empresas: resultados de uma pesquisa no Brasil. Disponível em: <www.ead.fea.usp.br/Semead/8semead/resultado/trabalhosPDF>. Acesso em: 22.06.2009; PASIN, Rodrigo M.; MARTELANC, Roy; Souza, Almir F. A flexibilidade do processo decisório e o valor da opção de adiamento. VI SEMEAD - Seminários em Administração FEA-USP. (Março, 2003). Disponível em: <http://www.ead.fea.usp.br/Semead/6semead/ > . Acesso em: 22.06.2009.

${ }^{243}$ Posterga-se um projeto quando o valor presente do negócio for menor que o valor do investimento. Nesse caso, o valor da opção (preço de exercício) é o valor do investimento inicial e a duração da opção é o prazo no qual o investidor tem o direito de aceitar o negócio. Por isso, o projeto pode ter valor presente negativo e, mesmo assim, interessar ao investidor, ou pode ter valor presente positivo e ser rejeitado, dependendo das condições para exercício da opção de adiar o negócio. O projeto é expandido quando a expectativa de retorno aumenta como consequência da expansão, isto é, o investidor entende que o projeto proporcionará oportunidades significativas no futuro, ainda que o valor presente líquido seja negativo. Normalmente, a expansão é mais vantajosa em mercados menos desenvolvidos, nos quais o retorno sobre o investimento pode ser mais alto que em mercados estabelecidos. A hipótese de liquidar (abandonar) o projeto é opção de venda, decisão tomada pelo investidor quando o fluxo de caixa do projeto não corresponde às expectativas, ou seja, quando o negócio não apresenta a taxa de retorno esperada. (DAMODARAN, As wath. Op.cit., pp. 319-322). 
Como a due diligence revela informação que permite modificar as condições do negócio, o investidor tende a não exercer a opção, momento em que nasce a segunda opção, na qual é apresentada contraproposta. Trata-se de "opção de compra" de participação no negócio, emitida em favor do empreendedor, que depende de aceitação nos prazos e condições estabelecidos e, se aceita, resulta na contratação do ne gócio.

Quando o contrato é concluído inicia-se o projeto. DAMODARAN define projeto como um conjunto de atividades organizadas para o desenvolvimento do objeto do negócio, estabelecendo prazos, condições de execução e forma de alocação dos recursos. Refere-se à decisão de investimento de recursos escassos em empreendimento que tem objetivo de gerar receitas a partir da venda de produtos e serviços, ou reduzir custos de produção ${ }^{244}$.

O projeto de venture capital é representado por um fluxo de caixa projetado que perdura por vários anos, analisado sob a perspectiva do valor presente líquido de caixa ou equivalentes de caixa ${ }^{245}$. Inicialmente, o fluxo de caixa é negativo, porque há fornecimento de recursos com expectativa de recuperação futura. Com o passar do tempo, se o desempenho do projeto for satisfatório, haverá retorno positivo sobre o

${ }^{244}$ DAMODARAN, Aswath. Finanças corporativas - teoria e prática. Porto Alegre: Bookman, $2^{\mathrm{a}}$ Ed., 2004, pp. 203-204.

245 A perspectiva de geração de caixa, ou seu equi valente, é medida de avaliação do desempenho do negócio. Nesse sentido, o Comitê de Pronunciamentos Contábeis indica, nos itens 15 e 16 do Pronunciamento Conceitual Básico, as principais razões para tal entendimento, que reproduzimos abaixo: "15. As decisões econômicas que são tomadas pelos usuários das demonstrações contábeis requerem uma avaliação da capacidade que a entidade tem para gerar caixa e equivalentes de caixa, e da época e grau de certeza dessa geração. Em última análise, essa capacidade determina, por exemplo, se a entidade poderá pagar seus empregados e fornecedores, os juros e amortizações dos seus empréstimos e fazer distribuições de lucros aos seus acionistas. Os usuários poderão melhor avaliar essa capacidade de gerar caixa e equi valentes de caixa se lhes forem fornecidas informações que focalizem a posição patrimonial e financeira, o resultado e as mutações na posição financeira da entidade". "16. A posição patrimonial e financeira da entidade é afetada pelos recursos econômicos que ela controla, sua estrutura financeira, sua liquidez e solvência, e sua capacidade de adaptação às mudanças no ambiente em que opera. As informações sobre os recursos econômicos controlados pela entidade e a sua capacidade, no passado, de modificar esses recursos são úteis para prever a capacidade que a entidade tem de gerar caixa e equivalentes de caixa no futuro. Informações sobre a estrutura financeira são úteis para prever as futuras necessidades de financiamento e como os lucros futuros e os fluxos de caixa serão distribuídos entre aqueles que têm participação na entidade; são também úteis para ajudar a avaliar a probabilidade de que a entidade seja bem-sucedida no levantamento de financiamentos adicionais. As informações sobre liquidez e solvência são úteis para prever a capacidade que a entidade tem de cumprir com seus compromissos financeiros nos respectivos vencimentos. Liquidez se refere à disponibilidade de caixa no futuro próximo, após considerar os compromissos financeiros do respectivo período. Solvência se refere à disponibilidade de caixa no longo prazo para cumprir os compromissos financeiros nos respectivos vencimentos". (COMITE DE PRONUNCIAMENTOS CONTÁBEIS. Pronunciamento conceitual básico. Estrutura conceitual para a elaboração e apresentação das demonstrações contábeis. Disponível em: <http://www.cpc.org.br〉. Acesso em: 09.09.2011). 
investimento $^{246,247}$.

\section{Monitoramento}

$\mathrm{Na}$ etapa de monitoramento, que se inicia após a contratação, há acompanhamento dos eventos críticos do projeto e avaliação contínua do desempenho das atividades.

O monitoramento pode ser dividido em duas etapas. A primeira aborda a estruturação da forma de administração do negócio e a implantação de controles sobre o desempenho do projeto. Ao final pode haver mudanças na estrutura de administração e fiscalização do empreendimento, ou mesmo redefinição de estratégias do negócio ${ }^{248}$. $\mathrm{Na}$ segunda etapa ocorre o monitoramento propriamente dito, realizado a partir de medidas observáveis de desempenho financeiro e não financeiro.

Certos eventos críticos podem ser previstos e contratados ex ante, ou seja, podem constar de cláusulas contratuais previamente estabelecidas, mas pode haver eventos não antecipáveis pelas partes, identificados somente após o início da execução das atividades.

\footnotetext{
${ }^{246}$ De acordo com AGHION e BOLTON, o empreendedor sempre pode adotar combinações de alternativas de financiamento, entre elas, empréstimo bancário, emissão de títulos de dívida ou emissão de novos valores mobiliários. Para eles, a decisão implica em maior ou menor compartilhamento das decisões com o credor ou sócio. (AGHION, Philippe; BOLTON, Patrick. An incomplete contracts approach to financial contracting. Review of Economic Studies, vol. 59, n. 200. July, 1992. Disponível em: <http://www.jstor.org/stable/2297860>. Acesso em: 27.01.2012, pp. 473-475).

${ }^{247}$ Não é pacífico o debate a respeito das melhores alternativas de financiamento e da necessidade, ou não, de existência de um mercado de valores mobiliários robusto para viabilizar investimentos de venture capital. BLACK e GILSON afirmam haver correlação positiva, mas GOMPERS e LERNER não encontraram correlação em seus estudos, porém não conseguiram refutar a hipótese. (BLACK, Bernard S.; GILSON, Ronald J. Does venture capital require an active stock market? Winter, 1999. Disponível em: <http://papers.ssrn.com/paper.taf?abstract_id=219174>. Acesso em: 20.09.2010; Venture capital and the structure of capital markets: banks versus stock markets. November, 1997. Disponível em: <http://papers.ssrn.com/paper.taf?abstract_id=46909>. Acesso em: 04.08.2009; GOMPERS, Paul A.; LERNER, Josh. The venture capital cycle. $2^{\text {nd }}$ ed., Cambridge: MIT Press, 2006, p. 45).

${ }^{248}$ Vide, por exemplo, o Plano de 100 Dias e o monitoramento contínuo do negócio, indicados em estudo específico realizado em países da Comunidade Europeia. (Fundação Getúlio Vargas (GVCEPE). A indústria de private equity e venture capital - segundo censo brasileiro. $1^{\text {a }}$ Ed., Março/2011. Disponível em: <http://gvcepe.com/>. Acesso em: 03.04.2012, pp. 297-310).
} 
A função do monitoramento é revelar informação sobre o desempenho do negócio em cada etapa, determinando a política de financiamento ${ }^{249,250}$ e o interesse em investir recursos na etapa seguinte. Em caso de desempenho favorável do negócio em uma etapa, haverá investimento na seguinte, mas se o desempenho for insatisfatório, o investidor pode decidir interromper perdas. Nesse caso, podem ocorrer as seguintes situações: o investidor abandona o projeto e resgata os recursos, caso em que o ne gócio continua com os demais sócios, porém sem recursos suficientes para desenvolver-se plenamente (denominado de projeto "zumbi", ou "morto-vivo"); o investidor cede a participação a outros investidores e o negócio prossegue; há dissolução da sociedade; há pedido de falência ou recuperação judicial.

O monitoramento do negócio ocorre por intermédio dos órgãos de administração e fiscalização, com participação de representantes do investidor e do empreendedor. Os limites da atuação dependem do tipo contratual adotado, contemplando regras de participação societária, acordos de sócios e outras avenças que assegurem o exercício dos direitos e limitar os riscos do negócio.

O investidor participa ativamente da administração e definição da estratégia do negócio, monitorando o desempenho financeiro e operacional. Trata-se de jogo não cooperativo de informação assimétrica, imperfeita e incompleta, no qual pode haver

${ }^{249}$ SANVICENTE explica que a política de dividendos, elemento central da administração financeira, referese à decisão entre reter (reinvestir) o lucro líquido ou distribuí-lo aos acionistas como rendimento por seus investimentos na sociedade. $O$ autor explica que a política ideal de financiamento busca a melhor combinação entre as duas opções, que implicam na escolha de fontes adequadas: a retenção de lucros permite financiar o negócio com recursos próprios, ao passo que a distribuição de dividendos aos sócios reduz a disponibilidade interna de recursos, obrigando a sociedade a buscá-los no mercado. (SANVICENTE, Antonio Z. Administração financeira, São Paulo: Atlas, $3^{\text {a }}$ Ed., 2008, pp. 107-108).

${ }^{250} \mathrm{Na}$ literatura especializada em direito e economia há diversos modelos que estudam o problema e propõem explicações e soluções de equilíbrio, a nosso ver, todos incompletos. Ver: HART, Oliver. Financial contracting. Journal of Economic Literature, vol. 39, N. 4, Dez. 2001, Disponível em: <http://www.jstor.org/stable/2698520>. Acesso em: 07.09.2010; AGHION, Philippe; BOLTON, Patrick. An incomplete contracts approach to financial contracting. Review of Economic Studies, vol. 59, n. 200. July, 1992. Disponível em: <http://www.jstor.org/stable/2297860>. Acesso em: 27.01.2012, pp. 490-492; MYERS, Stewart; MAJLUF, Nicholas. Corporate financing and investment decisions when firms have information the investors do not have. National Bureau of Economic Research. Working Paper 1396 (July 1984). Disponível em: < http://www.nber.org/papers>. Acesso em: 27.01.2012; BERGLÖF, Erik; VON THADDEN, Ernst-Ludwig. Short-term versus long-term interests: capital structure with multiple investors. Quarterly Journal of Economics, vol. 109, n. 4 (Nov., 1994). Disponível em: <http://www.jstor.org/stable/2118356>. Acesso em: 27.01.2012; DIBVIG, Philip H.; ZENDER, Jaime F. Capital structure and dividend irrelevance with asymmetric information. Review of Financial Studies, n. 4, 1991, pp. 201-219. Disponível em: <http://leeds-faculty.colorado.edu/Zender/papers/Irrelevance.pdf>. Acesso em: 12.04.2012). 
desalinhamento de incentivos entre investidor e empreendedor. O jogo é finito, pois na etapa de desinvestimento o investidor retira-se do negócio e este continua a operar com outros sócios.

O monitoramento do projeto é atividade complexa e de elevado custo, havendo dificuldade para verificar o cumprimento do contrato e a correta execução das estratégias definidas. O principal instrumento de controle é o desempenho econômicofinanceiro, revelado através do balanço patrimonial e dos demonstrativos financeiros publicados periodicamente. Pode haver incentivos para comportamento oportunista, no sentido de adotar práticas contábeis ou administrativas indevidas visando à obtenção de ganhos para os administradores ou para a sociedade (estratégia de earnings management ${ }^{251}$ ).

É relevante monitorar se o empreendedor e os administradores do negócio estão agindo no interesse da sociedade, ou, ao contrário, se buscam usufruir dos benefícios privados do controle. O jogo em questão é assimétrico, requer o alinhamento de incentivos e o estabelecimento de medidas de fiscalização. A avaliação de desempenho do ne gócio é essencial para revelar informação sobre a qualidade dos administradores e do projeto $^{252}$

A preservação dos bens imateriais produzidos pelo empreendimento é fator crítico para o sucesso do projeto, podendo essa proteção ser jurídica (exemplo: patentes) ou estratégica (exemplo: acordos de segredo industrial). Normalmente, a informação é de difícil mensuração, evidenciação e reconhecimento contábil. É fundamental haver preservação do capital intelectual antes do início da etapa de desinvestimento, porque a existência desses direitos de propriedade costuma afetar o preço de venda do negócio.

${ }^{251}$ LOPES, Alexsandro B. Earnings management and corporate governance: legal and regulatory implications. Revista de Direito Mercantil, Industrial, Econômico e Financeiro, Ano L, Vol. 158, pp. 7-25, 2011.

${ }^{252}$ Fundação Getúlio Vargas (GVCEPE). A indústria de private equity e venture capital - segundo censo brasileiro. $1^{\text {a }}$ Ed., Março/2011. Disponível em: <http://gvcepe.com/>. Acesso em: 03.04.2012, pp. 289-290. 
Também é comum haver cláusulas contratuais limitando a demissão voluntária ou involuntária de especialistas técnicos, inclusive do empreendedor. A principal forma é a atribuição de participação nos resultados condicionada à permanência no negócio, como, por exemplo, concessão de stock options com resgate escalonado ao longo do tempo. Entretanto, sempre haverá ameaça crível de abandono prematuro do empreendimento pelos envolvidos, porque a legislação considera abusiva a cláusula contratual que impeça empregados de se demitirem, e a retirada de sócio é definida como um direito essencial.

\section{Desinvestimento}

$\mathrm{Na}$ etapa de desinvestimento, ou "saída", pode ocorrer uma das seguintes alternativas: 1) venda da participação a terceiros; 2) "saída" do sócio investidor (dissociação); 3) dissolução da sociedade.

O desinvestimento pode se dar quando o negócio bem sucedido, ou não, foi concluído ou ainda está em desenvolvimento. A operação pode adotar uma das seguintes formas básicas ${ }^{253}:$ 1) oferta pública inicial de ações; 2) venda pública de controle de sociedade previamente listada em bolsa de valores; 3) venda privada de participação no negócio a outros investidores, normalmente compradores estratégicos, sem oferta pública ao mercado (trade sale); 4) no caso de fundos de investimento, pode ocorrer a venda de participação de um fundo a outro, através da cessão das posições investidas; 5) retrovenda ou recompra (buy-back), pelo empreendedor, da participação detida pelo investidor ${ }^{254}$.

A escolha do tipo de operação de venda afeta a seleção da informação relevante a ser disponibilizada aos potenciais compradores e as atividades necessárias para execução da operação, como por exemplo, contratação de instituição financeira

\footnotetext{
${ }^{253}$ Ver detalhamento sobre as modalidades de saída no mercado brasileiro em: Fundação Getúlio Vargas (GVCEPE). A indústria de private equity e venture capital - segundo censo brasileiro. $1^{\mathrm{a}}$ Ed., Março/2011. Disponível em: <http://gvcepe.com/>. Acesso em: 03.04.2012, pp. 209-216.

${ }^{254}$ GOMPERS, Paul A.; LERNER, Josh. The venture capital cycle. $2^{\text {nd }}$ ed., Cambridge: MIT Press, 2006, p. 28.
} 
intermediária (underwriter) para organizar a operação de subscrição de ações, publicação de informações, busca por interessados na aquisição da participação, etc.

O desinvestimento antes do término do desenvolvimento das atividades pode se dar por meio de: resgate ou liquidação das participações, por motivos previstos em contrato, com consequente desligamento do sócio; dissociação; dissolução; pedido de falência ou recuperação judicial.

O retorno de negócios de venture capital é medido a partir de um conjunto de fluxos de caixa projetados por vários anos. Inicialmente há fluxo negativo com período e valor desconhecidos até que ocorra o término do projeto, normalmente de longa duração. O resultado líquido final somente poderá ser calculado ao final do desenvolvimento das atividades. Por isso, a fórmula de retorno anual sobre o investimento costuma ser inadequada para avaliar o desempenho destes negócios, sendo necessário utilizar soluções mais sofisticadas, como por exemplo, a "Curva J", que captura resultados plurianuais ${ }^{255}$.

Para os potenciais compradores, interessa a demonstração de fluxos de caixa futuros, isto é, a possibilidade de gerar caixa depois que a ideia inovadora estiver completamente desenvolvida. Como a informação é incompleta e imperfeita, há incerteza para os potenciais compradores. Por isso, o investidor pode decidir manter uma parte de sua participação no negócio por determinado período e vender o restante a terceiros, visando a sinalizar ao comprador a qualidade do projeto e seu compromisso com a continuidade do negócio.

\footnotetext{
${ }^{255}$ A modalidade ideal é conhecida como "Curva J" ( $J$-curve), pois resulta em uma curva que apresenta o formato da letra "J". Trata-se de fórmula que calcula os retornos acumulados do investimento ao longo do tempo, usando a taxa interna de retorno como base. A J-curve permite acumular o resultado dos retornos negativos decorrentes dos aportes de capital e dos retornos positivos decorrentes do retorno sobre o capital, pagamento de dividendos e desinvestimento, ao final da última etapa do projeto. O retorno bruto é calculado sem desconto das taxas de administração e taxas de performance comumente aplicadas a negócios de venture capital. O retorno líquido, por sua vez, desconta as duas taxas. (Fundação Getúlio Vargas (GVCEPE). A indústria de private equity e venture capital - segundo censo brasileiro. $1^{\mathrm{a}}$ Ed., Março/2011. Disponível em: <http://gvcepe.com/>. Acesso em: 03.04.2012, pp. 216-222).
} 


\section{VI.2. Fundos de Investimento: Regime Jurídico Aplicável}

Investidores em negócios de venture capital podem organizar-se de duas maneiras: constituindo sociedade; organizando fundo de investimentos, a forma mais comum. Na primeira, uma sociedade é constituída visando à participação em outras sociedades. Na segunda, estabelece-se uma comunhão de investidores que aporta recursos em projetos.

Quando o investidor adota forma de sociedade, o objetivo é de participação em outras sociedades, aplicando-se as regras gerais de constituição e funcionamento do tipo societário adotado. A opção pela forma societária implica em assunção de responsabilidades distintas das atribuídas aos fundos de investimento. As normas aplicáveis aos fundos costumam ser mais benéficas, em especial, as que estabelecem menor incidência de tributos.

No passado, quando havia maior incerteza a respeito do regime jurídico aplicável a venture capital, o investidor adotava forma de sociedade holding, sediada no exterior, para participação em outros negócios. A holding fornecia recursos à sociedade brasileira, que podia ser o próprio empreendimento de venture capital ou uma sociedade intermediária que funcionava como veículo legal para captação dos recursos e posterior aporte no negócio que é o objeto do investimento ${ }^{256}$. Tal situação não mais ocorre, pois e possível estruturar fundos de investimento com a finalidade de investir os recursos captados.

O regime jurídico dos fundos de investimento é complexo e de difícil sistematização ${ }^{257,258}$. Fundos são organizados para captar recursos de terceiros. Os

\footnotetext{
${ }^{256}$ Fundação Getúlio Vargas (GVCEPE). A indústria de private equity e venture capital - segundo censo brasileiro. $1^{\text {a }}$ Ed., Março/2011. Disponível em: <http://gvcepe.com/>. Acesso em: 03.04.2012, pp. 72-77; 86. ${ }^{257}$ FORTUNA, Eduardo. Mercado financeiro - produtos e serviços. $18^{\mathrm{a}}$ ed., Rio de Janeiro: Qualitymark, 2010, pp. 551-688; LAVCA (Latin America Venture Capital Association). Guia para term sheets de venture capital e private equity, 2012. Disponível em: <www.lavca.org>. Acesso em 19.02.2013; Guia para contratos de venture capital e private equity, 2012. Disponível em: <www.lavca.org>. Acesso em 19.02.2013; LOPES, Alexsandro B.; FURTADO, Cláudio V. Private equity na carteira de investimentos das entidades de previdência privada. Revista de Contabilidade e Finanças USP - Especial Atuária. São Paulo, pp. 108-126, Dez. 2006.

${ }^{258}$ Instruções CVM n. 209/94, n. 391/03, n. 409/03, n. 406/04, n. 438/06. Disponível em: <www.cvm.gov.br>. Acesso em 05.11.2011. Outros fundos, como por exemplo, os fundos de investimento
} 
administradores dos fundos tomam parte ativa na administração dos recursos. Os demais cotistas são pessoas naturais ou jurídicas que fornecem o capital necessário, podendo ser fundos de pensão, fundações, companhias seguradoras, etc.

Para WALD, o fundo de investimento é definido como um condomínio especial com patrimônio separado e destinação específica, que se submete a regime próprio, variando em função da natureza do fundo 259 .

SZTAJN esclarece que o regulamento pactuado entre o fundo e os cotistas (condôminos) estabelece negócio fiduciário atípico, no qual uma das partes recebe da outra os bens para serem administrados em proveito do instituidor ou de terceiro ${ }^{260}$.

ROPPO explica que o negócio é baseado em relação de confiança, pois o fiduciante transfere bens ao fiduciário, que se obriga a administrá-los e conservá-los segundo determinado critério, transferindo, ao final do prazo contratual, os bens ao fiduciante ou a terceiro indicado no acordo. $\mathrm{O}$ contrato produz efeitos reais para o fiduciário e efeitos obrigacionais para o fiduciante. ROPPO indica que o contrato não estabelece obrigação moral, mas prestação coercível, porque fundada em uma troca econômica de bens por serviços prestados. O negócio implica em risco de abuso por parte do fiduciário, exigindo fiscalização pelo fiduciante, porque há dissociação entre a

em direitos creditórios (FDIC), fundos de investimentos imobiliários (FII) e investimentos do fundo de garantia por tempo de serviço (FGTS) em infraestrutura (FI-FGTS, Lei n. 11.491/2007) não serão analisados. ${ }^{259}$ WALD define fundo de investimento como uma forma especial de condomínio, uma universalidade de direitos com capacidade de representação judicial, porém sem órgãos de administração, característica que os distinguiria das pessoas jurídicas. Entende que o fundo é uma fórmula fiduciária na qual os investimentos são realizados em nome do fiduciário e no interesse do fiduciante, assemelhando-se ao trust. (WALD, Arnoldo. Da natureza jurídica do fundo imobiliário. Revista de Direito Mercantil, Industrial, Econômico e Financeiro, Ano XXIX, n. 80, Out./Dez. 1990, pp. 15; 23). O autor refere que o artigo 49 da Lei n. 4.728/65 exige que os fundos recebam autorização para funcionamento, obtida junto ao Banco Central do Brasil. Ainda, o artigo 50 da lei autorizava a transformação dos fundos em sociedades de investimento, que tomavam a forma de sociedade anônima de capital autorizado. (WALD, Arnoldo. Da natureza jurídica do fundo imobiliário. Revista de Direito Mercantil, Industrial, Econômico e Financeiro, Ano XXIX, n. 80, Out./Dez. 1990, p. 16).

${ }^{260}$ Referindo-se ao fundo imobiliário, SZTAJN entende que este parece aproximar-se do conceito de negócio fiduciário, assemelhado ao trust, no qual uma das partes recebe da outra um conjunto de bens para serem administrados em proveito do instituidor ou de terceiro. Nesse caso, porém, não há plena transferência da propriedade ao administrador do fundo, cabendo a este apenas a administração dos bens em benefício dos proprietários. Trata-se de forma atípica de negócio fiduciário porque não pode haver confusão dos bens objeto do contrato com os demais bens de propriedade do administrador do fundo. Além disso, o fundo não tem personalidade jurídica e, portanto, não pode ser titular de patrimônio, entendido como o complexo de posições jurídicas ativas e passivas. (SZTAJN, Rachel. Quotas de fundos imobiliários - novo valor mobiliário. Revista de Direito Mercantil Industrial Econômico e Financeiro, São Paulo, Ano XXXIII, v. 93, Jan./Mar. 1994, p. 106). 
titularidade dos bens de propriedade do primeiro e os interesses do segundo ${ }^{261}$. ROPPO aproxima o negócio fiduciário do trust, que define como contrato no qual o titular (settler) transfere bens a um sujeito (trustee) que exerce os poderes de titular não em vista de interesse próprio, mas em favor de um ou mais beneficiários, ou em função de determinado escopo. A relação jurídica fundamental não é a subjetiva, mas a relação objetiva que estabelece a condição jurídica do bem, relativamente ao negócio estipulado $^{262}$.

As previsões do Código Civil para reger os condomínios são inadequadas para fundos mútuos de investimento ${ }^{263,264}$, aplicando-se disciplina específica, determinada pela Lei n. 4.728/65 (Lei do Mercado de Capitais) e Instruções da CVM, que os sujeita a regras próprias de constituição, operação, fiscalização e encerramento ${ }^{265}$.

De acordo com as Instruções CVM, os fundos de investimento não têm personalidade jurídica, mas, para serem autorizados a funcionar, devem ser previamente registrados na $\mathrm{CVM}^{266}$ e possuir identificação no Cadastro Nacional de Pessoas Jurídicas ${ }^{267}$. Trata-se de mero registro que não tem o condão de atribuir personalidade jurídica ao fundo, servindo apenas para facilitar a atividade de supervisão e fiscalização a cargo da CVM.

As Instruções CVM preveem relativa autonomia e discricionariedade para

\footnotetext{
${ }^{261}$ ROPPO, Vincenzo. Il contrato. Milano: Ed. Giuffrè, 2001, pp. 681-685.

${ }^{262}$ ROPPO, Vincenzo. Op.cit., pp. 689-690.

${ }^{263}$ SZTAJN, Rachel. Quotas de fundos imobiliários - novo valor mobiliário. Revista de Direito Mercantil Industrial Econômico e Financeiro, São Paulo, Ano XXXIII, v. 93, Jan./Mar. 1994, p. 105.

${ }^{264}$ WALD explica: "nos países que ainda não conheciam o trust e que estão ferrenhamente vinculados à noção estrita de pessoa jurídica, como a França, foi preciso que a legislação esclarecesse mais detidamente a natureza jurídica do Fundo. Assim, a Lei francesa 79.594, de 13.7.79, que trata dos fundos, determinou expressamente que não se lhes aplicam as normas sobre indivisão e sociedades, sendo o Fundo o substituto legal dos coproprietários na titularidade dos direitos que lhes pertencem em condomínio, cabendo a gestão, inclusive com poderes amplos de representação judicial e de alienação de bens, a uma pessoa física ou jurídica atuando em nome do fundo e por conta dos respectivos quotistas". (WALD, Arnoldo. Da natureza jurídica do fundo imobiliário. Revista de Direito Mercantil, Industrial, Econômico e Financeiro, Ano XXIX, n. 80, Out./Dez. 1990, p. 22).

${ }^{265}$ EIZIRIK, GAAL, PARENTE e HENRIQUES entendem que as Instruções CVM que regulam fundos de investimento fizeram opção clara pela natureza jurídica de condomínio sem personalidade jurídica, constituído como comunhão de recursos, com feição contratual, não societária. (EIZIRIK, Nelson; GAAL, Ariadna B.; PARENTE, Flávia; HENRIQUES, Marcus de Freitas. Mercado de capitais - regime jurídico. $3^{\mathrm{a}}$. Ed., Rio de Janeiro: Renovar, 2011, pp. 83-84).

${ }^{266}$ Por exemplo, artigo $3^{\circ}$ da Instrução CVM n. 391/03.

${ }^{267}$ Por exemplo, artigo 19 da Instrução CVM n.209/94.
} 
elaboração do regulamento interno dos fundos, podendo prever órgãos de administração, comitês de fiscalização e auditoria, assembleias de cotistas com funções e poderes de deliberação especiais.

O administrador recebe dos demais cotistas do fundo remuneração calculada como percentual sobre o valor total dos recursos administrados, denominada impropriamente de "taxa de administração". Normalmente, a remuneração do administrador é acrescida de outro valor, a "taxa de desempenho", ou "taxa de performance" ${ }^{268}$, calculada sobre a rentabilidade líquida produzida pelo fundo.

O administrador pode ser pessoa natural ou jurídica e, se for jurídica, exige-se a nomeação de pessoa natural para atuar como administrador, que será seu representante legal. A responsabilidade, de natureza subjetiva, inclui a administração diligente dos recursos e a regular e periódica prestação de contas aos cotistas, bem como o atendimento às exigências dos órgãos reguladores.

Nos fundos de investimento há obrigações contratuais certas, como o dever de investir os recursos segundo os parâmetros determinados pelo regulamento interno e Instruções da CVM. Há também obrigações de natureza eventual, como o pagamento da remuneração pelo desempenho do fundo, um evento futuro e incerto que depende do resultado alcançado com a aplicação dos recursos postos à disposição do fundo.

Em relação aos cotistas, a responsabilidade do administrador é de natureza fiduciária ${ }^{269}$ e refere-se, principalmente, ao cumprimento dos termos e condições estabelecidos pelo regulamento, administração diligente dos fundos sob sua gestão e cumprimento das normas legais ${ }^{270}$. Se o administrador atuar fora dos limites estabelecidos pela lei ou pelo regulamento, causando prejuízos aos cotistas e ao

\footnotetext{
${ }^{268}$ Discordamos do uso do termo "taxa", porque significa, em Direito Tributário, contraprestação pelo exercício regular do poder de polícia, ou utilização, efetiva ou potencial, de serviço público específico e divisível, prestado ao contribuinte ou posto à sua disposição (artigo 77 do Código Tributário Nacional, Lei n. 5.172/66). Mais adequado seria o termo "preço", para significar remuneração pela prestação de serviços aos cotistas, realizada pelo administrador do fundo.

${ }^{269}$ EIZIRIK, Nelson; GAAL, Ariadna B.; PARENTE, Flávia; HENRIQUES, Marcus de Freitas. Mercado de capitais - regime jurídico. $3^{\mathrm{a}}$. Ed., Rio de Janeiro: Renovar, 2011, p. 86.

${ }^{270}$ A Instrução CVM n. 306/99 prevê diversas condutas aplicáveis ao administrador, entre elas, deveres específicos de diligência e lealdade.
} 
mercado, responde pessoalmente pelos atos praticados, inclusive em caso de "desenquadramento", isto é, aplicação de recursos fora dos limites de investimento estabelecidos pela legislação ou pelo regulamento interno do fundo. $\mathrm{O}$ "desenquadramento" pode decorrer de conduta intencional do administrador ou derivar de alterações imprevistas no mercado. Não há responsabilidade do administrador pelo desempenho financeiro do fundo que esteja naturalmente sujeito à variação do mercado, isto é, quando o "desenquadramento" não se dá por culpa ou dolo ${ }^{271}$.

O regulamento do fundo pode definir requisitos a serem preenchidos pelo interessado em adquirir cotas, por exemplo, a obrigatoriedade de ser investidor qualificado $^{272}$. O cotista adere ao contrato do fundo e submete-se ao regulamento interno, ficando responsável pela integralização das cotas, pagamento pro rata dos custos de manutenção, remuneração do administrador e integralização de posições a descoberto em caso de fundo deficitário. A integralização das cotas é pré-requisito para funcionamento do fundo, uma vez que o patrimônio especial deve ser constituído $a$ priori para fazer frente aos custos operacionais e garantir as obrigações contraídas.

Os fundos de investimento em venture capital levam, em média, de três a cinco anos para serem estruturados. Segue-se período de aplicação dos recursos, que dura de cinco a dez anos, com possibilidade de extensão.

Normalmente, esses fundos são especializados, isto é, atuam em setor específico do mercado no qual os administradores conhecem as principais características e requisitos. Os fundos estruturam-se segundo um ou mais dos seguintes critérios: setor econômico: especialização em determinado setor de atuação, como por exemplo, biotecnologia, infraestrutura, tecnologia de informação e telecomunicações; grau de maturidade dos negócios que serão objeto de investimento; delimitação geográfica:

\footnotetext{
${ }^{271}$ EIZIRIK, Nelson; GAAL, Ariadna B.; PARENTE, Flávia; HENRIQUES, Marcus de Freitas. Mercado de capitais - regime jurídico. $3^{\mathrm{a}}$. Ed., Rio de Janeiro: Renovar, 2011, pp. 86-91.

${ }^{272}$ Investidores qualificados, assim como definidos pelo artigo 109 da Instrução CVM n. 409/04, são instituições financeiras, companhias seguradoras, sociedades de capitalização, entidades abertas e fechadas de previdência complementar, administradores de carteira, consultores de valores mobiliários autorizados pela CVM, regimes próprios de previdência social, instituídos pela União, Estados, Distrito Federal e Municípios, bem como pessoas físicas ou jurídicas com investimentos superiores a trezentos mil reais e que declarem, por escrito a condição de investidores qualificados. (EIZIRIK, Nelson; GAAL, Ariadna B.; PARENTE, Flávia; HENRIQUES, Marcus de Freitas. Op.cit., p. 99).
} 
atuação em regiões geográficas específicas nas quais os administradores do fundo conhecem a legislação e o mercado; período-base ou ano-calendário da captação dos recursos ("safra"); quantidade de cotistas; montante dos recursos captados junto ao mercado.

Há duas espécies principais de fundos utilizados em negócios de venture capital: 1) Fundos de Investimento em Empresas Emergentes (FIEE), regidos pela Instrução CVM n. 209/94 e, no caso de aporte de capital estrangeiro, os fundos FIEECE, regidos pela Instrução CVM n. $278 / 98^{273}$; 2) Fundos de Investimento em Participações (FIP), disciplinados pela Instrução CVM n. 391/03.

Tanto os FIEE quanto os FIP são fundos fechados que viabilizam a aplicação de recursos em projetos de venture capital, ainda que parte do mercado costume apontar o FIEE para negócios de venture capital e o FIP para investimentos de private equity.

O FIEE pode ter duração de até dez anos, prorrogável por decisão dos cotistas. As cotas devem ser idênticas e nominativas, podendo haver distribuição aberta ao público ou restrita a investidores selecionados. Não há res gate antecipado das cotas.

O FIEE deve, obrigatoriamente, investir ao menos $75 \%$ do patrimônio em “empresas emergentes" ou "emergentes inovadoras" 274. A sociedade investida é classificada como "emergente" se apresentar faturamento líquido anual inferior a 150 milhões de reais, determinado no momento do primeiro investimento, e não for controlada por grupo societário com patrimônio líquido consolidado superior a 300 milhões de reais (artigos $1^{\circ}, 2^{\circ}$ e $3^{\circ}$ da Instrução CVM n. 209/94); não necessita ser

\footnotetext{
${ }^{273}$ A Instrução n. 278/98, da CVM, disciplina o funcionamento de Fundos de Investimento em Empresas Emergentes de Capital Estrangeiro (FIEE - CE), do qual participam exclusivamente pessoas naturais ou jurídicas que sejam residentes, domiciliadas ou tenham sede social no exterior, além de fundos ou outras entidades estrangeiras de investimento coletivo. Esses fundos são constituídos sob a forma de condomínio fechado e dependem de autorização prévia para funcionamento, emitida pela CVM. Os FIEE-CE funcionam de forma semelhante aos FIEE. Os FIEE-CE obedecem a Resolução n. 2.406/97 e o registro obedece a regras definidas na Circular n. 3.492/10, do Banco Central do Brasil.

${ }^{274} \mathrm{O}$ fundo deve manter ao menos $75 \%$ das aplicações de recursos em ações, debêntures conversíveis em ações ou bônus de subscrição de ações de emissão de sociedades emergentes, e o restante em títulos ou cotas de fundos de renda fixa, bem como em valores mobiliários de companhias abertas, adquiridas diretamente em bolsa de valores ou mercado de balcão organizado. As operações com derivativos são proibidas, exceto as que tenham finalidade de proteção - hedge.
} 
constituída sob a forma de sociedade anôni ma e não precisa estar voltada à produção de invenções. A sociedade "emergente inovadora" pode pertencer a grandes grupos empresariais, apresentar patrimônio líquido de qualquer valor e deve, necessariamente, atuar na produção de invenções ${ }^{275}$.

O FIP limita a aquisição de cotas a investidores qualificados definidos pela CVM. Apresenta estrutura mais flexível para escolha do porte, maturidade, setor de atividade e diversificação dos recursos, podendo investir em qualquer companhia e adotar políticas de investimento mais abrangentes. Objetiva participar do negócio detendo influência significativa ou controle de sociedades ${ }^{276}$.

As formas de participação previstas nos FIP são: 1) aquisição de ações que integrem o bloco de controle e assegurem efetiva influência na definição da estratégia e na administração do negócio, inclusive com indicação e nomeação de membros do conselho de administração; 2) celebração de acordo de acionistas com as mesmas finalidades indicadas; 3) outros ajustes ou adoção de procedimentos que assegurem ao fundo a influência requerida. O fundo pode investir em companhias abertas ou fechadas $^{277}$.

Todas as cotas do fundo FIP são idênticas e nominativas. Ao contrário dos FIEE, é possível aos FIP estabelecer uma ou mais classes de cotas, atribuindo-lhes direitos políticos para matérias especificadas no regulamento do fundo, assim como direitos relativos à fixação das taxas de administração e de desempenho.

\footnotetext{
${ }^{275}$ Em razão das demandas introduzidas pela Lei de Inovação (Lei n. 10.973/04), a Instrução CVM n. 415/05 modificou a Instrução CVM n. 209/94 e introduziu os artigos 43-A e 43-B, permitindo classificar a sociedade investida como "emergente inovadora" quando, cumulativamente, for constituída conforme o artigo 23 da lei, adotar forma de sociedade anônima e a atividade principal estiver voltada à introdução de novidade ou aperfeiçoamento no ambiente produtivo ou social, desde que a inovação resulte em novos produtos, processos ou serviços, conforme o artigo $2^{\circ}$, IV, da lei.

${ }^{276}$ EIZIRIK, Nelson; GAAL, Ariadna B.; PARENTE, Flávia; HENRIQUES, Marcus de Freitas. Mercado de capitais - regime jurídico. $3^{\mathrm{a}}$. Ed., Rio de Janeiro: Renovar, 2011, p. 100.

${ }^{277} \mathrm{O}$ regulamento do fundo deve estabelecer os critérios para seleção das companhias abertas que serão objeto de investimento. $\mathrm{O}$ aporte de recursos em companhias fechadas depende de adoção obrigatória das práticas de governança corporativa previstas no artigo $2^{\circ}$, $\S^{\circ}$, da Instrução CVM. O FIP também pode investir em sociedades em processo de recuperação judicial ou reestruturação societária, desde que haja participação na administração. Nesse caso, é possível a integralização de cotas em bens ou direitos, inclusive créditos, desde que vinculados ao processo de recuperação e respaldados em laudo de avaliação de bens elaborado por profissional especializado.
} 
Os FIP têm maior discricionariedade na definição do regulamento interno, apesar de a Instrução CVM n. 391/03 ter especificado a forma de participação no processo decisório das companhias investidas e as regras para aporte de recursos. Compõem-se de comitê de investimentos, comitê técnico e conselhos consultivos ${ }^{278}$.

Muitas das regras de funcionamento dos fundos FIEE e FIP são similares, como por exemplo, as que orientam as atividades do administrador, as hipóteses para sua responsabilização, as competências atribuídas à assembleia-geral de cotistas e outras.

A disciplina para produção e publicação de demonstrações contábeis, estabelecida pela Instrução CVM n. 438/06, é idêntica para fundos FIEE e FIP 279 .

Quanto à tributação, também não há distinção significativa entre os fundos. A tributação é definida em função da pessoa do investidor, se natural ou jurídica, e se possui residência, sede ou domicílio no país ou no exterior ${ }^{280,281,282}$.

O artigo 37 da Instrução CVM n. $391 / 03$ permite a criação de Fundos de Investimento em Cotas de Fundos de Investimento em Participações (FIC-FIP), que são

\footnotetext{
${ }^{278}$ Fundação Getúlio Vargas (GVCEPE). A indústria de private equity e venture capital - segundo censo brasileiro. $1^{\text {a }}$ Ed., Março/2011. Disponível em: <http://gvcepe.com/>. Acesso em: 03.04.2012, pp. 105-106. ${ }^{279}$ Cabe mencionar também a Instrução CVM n. 302/99, que dispõe sobre a constituição, administração, funcionamento e divulgação de informações dos fundos de investimento em títulos e valores mobiliários, aplicável também a negócios de venture capital nos quais ocorra emissão dos títulos.

${ }^{280}$ De acordo com FORTUNA, a lei n. 11.312/06 isenta investidores estrangeiros não residentes de pagamento de imposto sobre a renda e ganhos de capital que não provenham de entidades registradas em paraísos fiscais, condicionado ao atendimento dos requisitos da Resolução n. 2.689/00, do Conselho Monetário Nacional. Considera-se investidor não residente a pessoa natural ou jurídica com residência, sede ou domicílio no exterior (artigo $1^{\circ}$ da Resolução CMN n. 2.689/00). Segundo o autor, a Lei n. 11.727/09 ampliou o conceito de países com tributação favorecida ("paraísos fiscais"), apresentado na Instrução Normativa n. 1.037/10, da Receita Federal do Brasil. A nova regra considera "paraíso fiscal" toda e qualquer jurisdição estrangeira que não permita acesso a informações sobre composição societária e identificação de beneficiários diretos de rendimento financeiro atribuído a não residentes. (FORTUNA, Eduardo. Mercado financeiro - produtos e serviços. $18^{\mathrm{a}}$ ed., Rio de Janeiro: Qualitymark, 2010, pp. 604; 654-669; 679-681).

${ }^{281}$ De acordo com o "Mapa de Incentivos" publicado pela ANBIMA, a tributação difere em função do tipo de fundo (FIP, FIC-FIP ou FIEE) e da condição pessoal do investidor. Há três situações: pessoa natural residente no país; pessoa jurídica residente no país; investidores não residentes ou domiciliados no país. Base jurídica: Leis n. 11.312/06, 11.478/07, 12.431/11; Instruções CVM n. 391/03, 406/04, 460/07 e 501/11. (Associação Brasileira das Instituições do Mercado de Capitais (ANBIMA). Mapa de incentivos. Disponível em: <http://www.anbima.com.br/informe_legislacao/arqs/MapaIncentivos.pdf>. Acesso em: 16.02.2013).

${ }^{282}$ Tramita na Câmara dos Deputados o projeto de lei n. 1.418/07, que pretende derrogar dispositivos da Lei n. 11.312/06 visando a eliminar a isenção tributária favorável a investidores não residentes. (Procuradoria Geral da Fazenda Nacional. "Isenção fiscal para investidor estrangeiro poderá acabar". Disponível em: <http://www.pgfn.fazenda.gov.br/noticias_importadas/ >. Acesso em: 16.02.2013).
} 
fundos de investimento em direitos de outros fundos FIP e FIEE, desde que pelo menos $90 \%$ do patrimônio seja aplicado nesses negócios ${ }^{283}$.

Anteriormente à criação da Instrução CVM n. 391, os investidores estrangeiros eram obrigados a adaptar as regras existentes para investimentos em fundos de ações, procedimento complexo e arriscado devido à incerteza a respeito da licitude de tais práticas $^{284}$.

Recentemente, a Associação Brasileira de Private Equity e Venture Capital (ABVCAP) ${ }^{285}$ e a Associação Brasileira das Instituições do Mercado de Capitais (ANBIMA) ${ }^{286}$ instituíram o Código de Regulação e Melhores Práticas para o Mercado de Fundos de Investimento ("Código ANBIMA"), de adesão obrigatória para os membros das entidades, cujo objetivo é uniformizar práticas de administração dos fundos, sujeitando-as a supervisão pelo Conselho de Regulação comum às duas instituições. Os fundos que aderirem às práticas recebem um selo de qualidade ${ }^{287,288}$.

\footnotetext{
${ }^{283}$ A divulgação de informações dos fundos de investimento é regida pela Instrução CVM n. 409/04, que estabelece, em seu artigo $1^{\circ}$, o rol dos fundos excluídos de sua disciplina por terem regras próprias, entre eles, os FIC-FIP, FIP e FIEE.

${ }^{284}$ LAVCA (Latin America Venture Capital Association). Guia para term sheets de venture capital e private equity, 2012. Disponível em: 〈www.lavca.org〉. Acesso em 19.02.2013.

285 Associação Brasileira de Private Equity e Venture Capital (ABVCAP). Disponível em: <http://www.abvcap.com.br/>. Acesso em: 16.02.2013.

286 Associação Brasileira das Instituições do Mercado de Capitais (ANBIMA). Disponível em: <http://portal.anbima.com.br/>. Acesso em: 16.02.2013.

${ }^{287}$ FORTUNA, Eduardo. Mercado financeiro - produtos e serviços. $18^{\mathrm{a}}$ ed., Rio de Janeiro: Qualitymark, 2010, pp. 623-624; 676 .

${ }^{288}$ O Código ANBIMA classifica os fundos segundo o grau de adesão às práticas recomendadas: Tipo 1: o fundo prevê a instalação e funcionamento do Comitê de Investimentos, com participação de representantes dos cotistas; Tipo 2: o fundo prevê a instalação e funcionamento do Comitê de Investimentos composto apenas por profissionais integrantes da administração ou da administração do fundo, se esta for independente, e, adicionalmente, um Conselho de Supervisão; Tipo 3: o fundo não prevê a instalação e funcionamento do Comitê de Investimentos. (Fundação Getúlio Vargas (GVCEPE). A indústria de private equity e venture capital - segundo censo brasileiro. $1^{\mathrm{a}}$ Ed., Março/2011. Disponível em: <http://gvcepe.com/>. Acesso em: 03.04.2012, pp. 100-101).
} 


\section{VI.3. Métodos para Avaliação de Investimentos: Principais Considerações}

Segundo MARTELANC, TRIZI, PACHECO e PASIN, não há, no Brasil, uso padronizado dos métodos de avaliação. Diversos fatores influenciam a escolha do método, entre eles, o conhecimento e experiência do avaliador; disponibilidade de informações e de tempo para realizar a avaliação; qualidade das informações disponíveis; existência de sociedades "comparáveis" ou informações sobre o setor de atuação; possibilidade de contato direto entre o produtor e o consumidor da informação produzida. Há, segundo os autores, pouca precaução dos agentes econômicos com o uso e adaptação de métodos "importados", que costumam ser inapropriados para avaliação de projetos no Brasil, devido à menor liquidez e tamanho do mercado ${ }^{289}$.

Os métodos descritos são usados, prioritariamente, para analisar investimentos e calcular o valor de negócios em andamento, por isso são de difícil aplicação a venture capital, especialmente aqueles em estágios iniciais de desenvolvimento, nos quais o alto grau de incerteza costuma inviabilizar estimativas confiáveis. A combinação de métodos de avaliação pode minimi zar o problema, mas não o elimina.

Descrevemos, brevemente, os principais métodos existentes, comentando a respeito de sua possibilidade de utilização em projetos de venture capital.

\section{Taxa interna de retorno e atratividade do investimento}

O método define a taxa mínima de atratividade do projeto, isto é, o custo de utilização do capital que iguala as taxas de juros praticadas pelo mercado. $\mathrm{O}$ investimento será atrativo se a taxa calculada superar a taxa de mercado escolhida como referência para comparação.

\footnotetext{
${ }^{289}$ Pesquisa realizada em 2004 no Brasil, que aponta para a diversidade dos métodos de avaliação utilizados, bem como o fato de que poucos métodos são usados para apoiar atividades de reestruturação societária. A pesquisa abrangeu os métodos contábil e patrimonial; valor de liquidação; múltiplos, ou avaliação relativa; fluxo de caixa descontado; valor econômico adicionado (EVA, ou economic value added); opções reais. (MARTELANC, Roy; TRIZI, Juliana S.; PACHECO, André A. S.; PASIN, Rodrigo M. Utilização de metodologias de avaliação de empresas: resultados de uma pesquisa no Brasil. Disponível em: <www.ead.fea.usp.br/Semead/8semead/resultado/trabalhosPDF >. Acesso em: 22.06.2009).
} 
Método similar é o cálculo da rentabilidade simples do investimento, que apresenta a relação entre o lucro, obtido em determinado período, e o valor total investido no projeto. A partir desta fórmula pode-se calcular o período necessário para obtenção do retorno sobre o investimento, ou seja, o tempo necessário para recuperar o capital investido no projeto.

Outro indicador de avaliação é o valor presente líquido, equivalente ao valor atual das entradas e saídas do fluxo de caixa gerado pelo projeto. A partir desse valor, pode-se aferir a taxa interna de retorno sobre o investimento, que é a taxa de juros que corresponde ao valor presente das entradas e saídas do fluxo de caixa do projeto. A taxa interna de retorno é o valor da taxa a partir da qual o negócio torna-se atrativo para o investidor. A taxa calculada deve superar o custo dos recursos alocados ao projeto $^{290,291}$.

Segundo tais medidas, para ser atrativo aos potenciais investidores, o negócio de venture capital deve demonstrar que o projeto produzirá fluxo de caixa livre e positivo, eliminando o déficit existente nos primeiros anos de investimento, segundo as expectativas do investidor.

\section{Fluxo de caixa descontado}

Na avaliação pelo método do fluxo de caixa descontado, o valor do negócio relaciona-se com o momento de distribuição dos saldos de caixa disponíveis. O fluxo de caixa depende, entre outros fatores, da projeção de receitas e despesas, margens de lucro, investimentos realizados e planejados, e custo de capital ${ }^{292}$.

SANVICENTE ensina que o método do fluxo de caixa descontado é superior porque considera os momentos de entradas e saídas de caixa, ignorados por outros métodos de avaliação, como por exemplo, o método do cálculo do período e da taxa de

\footnotetext{
${ }^{290}$ SECURATO, José R. Cálculo financeiro das tesourarias. $2^{\text {a }}$ ed., São Paulo: Saint Paul Institute of Finance Editora, 2003, pp. 26-33.

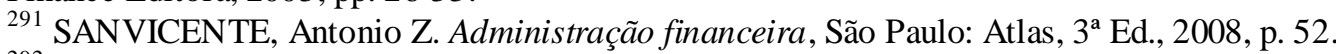

${ }^{292}$ MARTELANC, Roy; TRIZI, Juliana S.; PACHECO, André A. S.; PASIN, Rodrigo M. Utilização de metodologias de avaliação de empresas: resultados de uma pesquisa no Brasil. Disponível em: <www.ead.fea.usp.br/Semead/8semead/resultado/trabalhosPDF>. Acesso em: 22.06.2009.
} 
retorno $^{293}$.

O acompanhamento do fluxo de caixa é essencial para garantir o controle sobre a movimentação financeira e pode ser definido como o conjunto de entradas e saídas de caixa obtidas em determinado período. Serve para antecipar crises de liquidez e avaliar a existência de potenciais excedentes de caixa. O método realiza projeção das entradas e saídas, entretanto, normalmente, as saídas são mais fáceis de calcular que as entradas, porque dependem da efetiva liquidação das obrigações na data de vencimento. $\mathrm{O}$ fluxo de caixa pode servir para indicar ou projetar crise de liquidez em determinado momento, quando as saídas excedem as entradas ${ }^{294}$.

O fluxo de caixa é "livre" quando há sobras, após pagar aos credores e financiar as necessidades de custeio e investimento. Avalia-se o negócio pelo comportamento esperado para o fluxo de caixa futuro, não apenas pelo saldo atual de caixa. Analisamse as previsões de lucros, receitas e despesas que afetam o fluxo de caixa e, em seguida, define-se a taxa de desconto a ser aplicada ao investimento, isto é, a taxa que permite igualar o custo de financiamento do projeto. Se não houver fluxo de caixa livre em período futuro de tempo, haverá poucas possibilidades de sucesso do projeto.

Fluxo de caixa descontado é método no qual se aplica uma taxa de desconto para trazer a valor presente os custos da dívida e o patrimônio líquido. Como os custos podem variar ao longo do tempo, resultando na eventualidade de não pagamento aos credores, depende da previsão de obtenção de lucros e do tamanho do projeto. O fluxo de caixa também depende do grau de alavancagem do negócio, que indica a relação entre o montante do investimento realizado com capital próprio e de terceiros.

O uso do método de fluxo de caixa descontado implica em analisar o percentual de crescimento esperado para o lucro operacional, que, em certos mercados, pode ser comparado com o indicador médio do setor de atuação no qual o projeto se insere. A taxa de crescimento pode depender, entre outros fatores, do tamanho do negócio e do

${ }^{293}$ SANVICENTE, Antonio Z. Administração financeira, São Paulo: Atlas, $3^{\text {a }}$ Ed., 2008, pp. 42-43.

${ }^{294}$ SZTAJN, Rachel. Comentários. In SOUZA JR, Francisco Satiro de; PITOMBO, Antonio Sérgio A de Moraes (coord.). Comentários à lei de recuperação de empresas e falência. São Paulo: Revista dos Tribunais, 2005, pp. 251-252. 
percentual de aumento do retorno sobre novos investimentos. Como o valor do ne gócio depende do fluxo de renda gerada pelos ativos que a compõem, avalia-se o valor dos ativos e sua capacidade de produzir riqueza e, após sua comparação com o passivo, atribui-se valor ao empreendimento ${ }^{295}$.

As demonstrações financeiras de fluxo de caixa de projetos de venture capital tendem a ter baixa acuracidade, devido à incerteza sobre o desenvolvimento do negócio, que não apresenta referências de comparação com o mercado. A precisão do fluxo de caixa é baixa porque o prazo do negócio é longo, dificultando a análise. Projetos de venture capital levam vários anos para produzir resultados positivos, mas, do ponto de vista de análise de sobrevivência do negócio, a informação a respeito de fluxo de caixa é mais útil quando se avaliam prazos longos, porque permitem analisar tendências. Uma solução possível pode ser comparar as projeções de fluxo de caixa dos anos iniciais com o fluxo de caixa produzido no ano corrente para verificar a coerência entre os valores e a indicação de tendência. Para tal, os dois fluxos de caixa devem utilizar as mesmas premissas e critérios para geração das informações. O método comparativo, portanto, somente pode ser usado em negócios já em andamento.

Uma derivação do método é o "valor presente de saída", no qual são estimados, a valor presente, a expectativa de lucro futuro do negócio e a relação de preço-lucro da participação societária, para, depois, serem comparados com os valores de outros negócios do mesmo mercado e setor de atividade. Tal método é aplicável àqueles negócios nos quais há concorrentes estabelecidos, o que não é o caso da maioria dos empreendimentos de venture capital.

O retorno obtido com negócios de venture capital não pode ser medido em um único ano-calendário, pois o investimento é representado por um conjunto de fluxos de caixa projetados por vários anos. Os aportes de recursos ao negócio geram, inicialmente, fluxos de caixa negativos cujo período e valor são desconhecidos antes do término do projeto, normalmente de longa duração. Os retornos são representados por fluxos de caixa positivos com valor e periodicidade não totalmente conhecidos no

${ }^{295}$ DAMODARAN, Aswath. Finanças corporativas - teoria e prática. Porto Alegre: Bookman, 2a Ed., 2004, pp. 611-629. 
momento inicial em que é realizada a estimativa de retorno futuro. O resultado líquido somente será calculado ao final da última etapa do projeto, quando todos os dados são conhecidos.

Por isso, a fórmula clássica de retorno anual sobre o investimento é inadequada para avaliar o desempenho de negócios de venture capital, sendo necessário utilizar fórmula mais sofisticada, como por exemplo, a "Curva J", que captura o retorno plurianual de um projeto de longa duração ${ }^{296}$. A curva recebe esse nome porque se assemelha à letra "J", porém inclinada para a direita. Nos primeiros períodos de tempo a curva é decrescente, devido aos altos investimentos iniciais, e apresenta baixo retorno imediato, porém, com o passar do tempo, projetos de boa qualidade apresentam crescimento mais elevado.

\section{Avaliação por múltiplos}

Método aplicável a situações de menor complexidade é a avaliação por múltiplos, ou avaliação relativa. O método utiliza duas informações: o valor de mercado de outro negócio do mesmo ramo de atividade que apresente características semelhantes ao negócio em avaliação; um valor para comparação entre os dois negócios, que pode ser o saldo de fluxo de caixa, volume total de vendas, EBITDA, lucro líquido, etc. Exemplificando: o preço de venda equivale a seis vezes o valor do faturamento mensal do empreendimento, logo, o negócio de venture capital que fatura quinze milhões de reais alcançaria valor de venda de noventa milhões de reais.

O método de avaliação por múltiplos, apesar de amplamente utilizado, é suscetível a apresentar erros quanto à qualidade dos dados e análise dos fundamentos do negócio avaliado, bem como pode desconsiderar as especificidades do projeto ${ }^{297}$. Trata-se de questão importante em negócios de venture capital, que são dotados de alto grau de incerteza e apresentam poucas referências para comparação com negócios

\footnotetext{
${ }^{296}$ Fundação Getúlio Vargas (GVCEPE). A indústria de private equity e venture capital - segundo censo brasileiro. $1^{\text {a }}$ Ed., Março/2011. Disponível em: <http://gvcepe.com/>. Acesso em: 03.04.2012, pp. 216-222. ${ }^{297}$ MARTELANC, Roy; TRIZI, Juliana S.; PACHECO, André A. S.; PASIN, Rodrigo M. Utilização de metodologias de avaliação de empresas: resultados de uma pesquisa no Brasil. Disponível em: <www.ead.fea.usp.br/Semead/8semead/resultado/trabalhosPDF >. Acesso em: 22.06.2009.
} 
concorrentes no mercado.

DAMODARAN entende que a avaliação por múltiplos pode ser tão ou mais complexa quanto outros métodos, normalmente considerados mais sofisticados, como, por exemplo, a avaliação por fluxo de caixa descontado. $\mathrm{O}$ autor esclarece que os pressupostos da avaliação são explícitos no método de fluxo de caixa descontado e implícitos no método de avaliação por múltiplos, mas não são menos complexos de serem calculados, pois implicam em avaliar, por exemplo, o índice de preço/lucro por ação, índice de preço da ação/valor contábil, índice de preço/total de vendas, e outros que podem ser de difícil mensuração ${ }^{298}$.

Negócios de venture capital são inovadores e, normalmente, não possuem competidores que possam servir de padrão para comparação. Nesse caso, CAOUETTE, ALTMAN e NARAYANAN apontam método para analisar o risco de crédito de sociedades fechadas. Os autores propõem utilizar dados de sociedades abertas do mesmo mercado e estimar o valor alcançado pela sociedade investida. $\mathrm{O}$ valor de mercado é usado como oscilante entre dois valores, o operacional e o de liquidação. O valor de liquidação é calculado a partir do passivo contabilizado, e o valor operacional é calculado a partir do EBITDA, ao qual se aplica um multiplicador, em razão de variações no mercado. Quando o EBITDA é alto, o valor de mercado aproxima-se do valor operacional, e quando é baixo, aproxima-se do valor de liquidação. Os autores propõem estimar a volatilidade dos ativos da sociedade, calculada em função do tamanho das vendas, mercado, especificidade e porte dos ativos ${ }^{299}$.

O método proposto pelos autores desconsidera aspectos importantes: os cálculos utilizam informação declarada pela própria sociedade fechada, que pode ser viesada; a operacionalização da solução depende de haver dados disponíveis das sociedades abertas de mesmo mercado do qual participa a sociedade fechada, que podem ser de difícil obtenção para negócios inovadores; há presunção de que a sociedade fechada se comporta da mesma maneira que as companhias abertas do mesmo setor, o que nem

${ }^{298}$ DAMODARAN, Aswath. Finanças corporativas - teoria e prática. Porto Alegre: Bookman, 2a Ed., 2004, pp. 630-636.

${ }^{299}$ CAOUETTE, John B.; ALTMAN, Edward I.; NARAYANAN, Paul. Gestão do risco de crédito. Rio de Janeiro: Qualitimark, 2000, pp. 162-166. 
sempre é verdadeiro; a noção de EBITDA pode ser subjetiva e não refletir plenamente a informação lançada na contabilidade; às vezes, como explica STANGHELLINI, o negócio pode apresentar EBITDA positivo e apresentar sinais de crise, decorrente de administração inadequada ${ }^{300}$.

\section{Opções reais}

O método das opções reais é menos difundido devido à complexidade de realização dos cálculos necessários à tomada de decisão. É alternativa para análise de investimentos que dependem de eventos nos quais há incerteza, pois permite capturar o valor da flexibilidade gerencial, de difícil mensuração pelos métodos de fluxo de caixa descontado e de avaliação por múltiplos ${ }^{301}$.

O conceito de flexibilidade gerencial refere-se à possibilidade de rever constantemente as estratégias para aproveitar novas oportunidades ou reduzir perdas e aumentar o valor do investimento. Indica, para o investidor, o melhor momento de agir $^{302}$. Quanto maior a flexibilidade, mais atrativo será o investimento.

O método da avaliação por opções reais é derivado do conceito de opção de compra, que significa o direito de o investidor fazer determinada operação em condições pré-definidas, sem que haja qualquer obrigação de efetivar a transação. Por trazer vantagens ao investidor, a operação apresenta custo de aquisição e preço menores. As oportunidades de investimento podem ser vistas como opções de compra sobre ativos à disposição do investidor ${ }^{303}$.

O valor das opções depende de outro ativo associado à opção, denominado

\footnotetext{
${ }^{300}$ STANGHELLINI, Lorenzo. Crisi di impresa fra diritto ed economia - le procedure di insolvenza. Bologna: Il Mulino, 2007, p. 216.

${ }^{301}$ MARTELANC, Roy; TRIZI, Juliana S.; PACHECO, André A. S.; PASIN, Rodrigo M. Utilização de metodologias de avaliação de empresas: resultados de uma pesquisa no Brasil. Disponível em: <www.ead.fea.usp.br/Semead/8semead/resultado/trabalhosPDF >. Acesso em: 22.06.2009.

${ }^{302}$ MINARDI, Andrea M. A. F. Teoria das opções aplicada a projetos de investimento. Revista de Administração de Empresas (RAE), V. 40, n. 2, pp. 74-79, Abr./Jun. 2000.

${ }^{303}$ PASIN, Rodrigo M.; MARTELANC, Roy; Souza, Almir F. A flexibilidade do processo decisório e o valor da opção de adiamento. VI SEMEAD - Seminários em Administração FEA-USP. (Março, 2003). Disponível em: <http://www.ead.fea.usp.br/Semead/6semead/ >. Acesso em: 22.06.2009.
} 
ativo-objeto, que corresponde ao valor a ser investido no projeto de venture capital. A avaliação utiliza como taxa de desconto a taxa de retorno do ativo livre de riscos, evitando os difíceis cálculos de precificar o investimento usando diferentes taxas de desconto para diversos graus de exposição ao risco. A teoria das opções permite avaliar o investimento em um cenário neutro, enfocando a relação entre o preço da opção, preço do ativo-objeto, volatilidade e prazo de vencimento da opção. Com isso, a teoria das opções permite reduzir a subjetividade da avaliação, mas não a elimina. $O$ valor das opções ainda depende do valor do projeto (ativo-objeto), que fica submetido à subjetividade do avaliador. Além disso, considera-se a volatilidade do investimento, isto é, o desvio entre a taxa de retorno esperada e a efetivamente ocorrida; a volatilidade é, também, sujeita a algum grau de subjetividade ${ }^{304}$.

A teoria das opções pode ser aplicada a negócios de venture capital desde que exista um ativo-objeto que possa ser correlacionado ao investimento. As principais opções reais, relacionadas à decisão de investimento, são: postergá-lo; expandi-lo; contraí-lo; abandoná-lo; realizar investimentos dependentes do primeiro.

Em relação às opções reais relacionadas à decisão de investimento em negócios de venture capital, podemos entender que: 1) o valor da flexibilidade gerencial tende a ser relevante, porque há poucas restrições legais ou contratuais ao uso de estratégias gerenciais e, principalmente, não há mercado secundário para venda de projetos em andamento; 2) a opção de postergar o investimento pode ser relevante, especialmente em projetos que requerem o desenvolvimento de tecnologias de apoio incipientes, ou de procedimentos complexos e demorados de teste, como é o caso, por exemplo, do desenvolvimento de fármacos; 3 ) as opções de expansão ou contração do investimento estão relacionadas, também, à possibilidade, ou não, de transferência do negócio ainda não concluído a outros investidores; 4) é possível implementar a opção de abandono, quando o investidor desiste do projeto; neste caso, a sociedade deveria ser capaz de continuar a operar com recursos insuficientes para seu desenvolvimento, situação improvável em negócios de venture capital.

\footnotetext{
${ }^{304}$ MINARDI, Andrea M. A. F. Teoria das opções aplicada a projetos de investimento. Revista de Administração de Empresas (RAE), V. 40, n. 2, pp. 74-79, Abr./Jun. 2000.
} 
As opções reais podem ser precificadas como opções financeiras, mas há características que as distinguem: 1) o tempo de vida útil, mais longo para as opções reais; 2) a criticidade em relação ao momento ideal para exercício, maior em opções reais; 3) a possibilidade de comercializar o objeto do investimento é mais ampla quando se trata de opções financeiras, porque há mercado secundário; por isso, para que a opção real seja precificada de maneira adequada, é necessário encontrar um ativo de referência, negociado no mercado, que possa ser relacionado ao investimento ${ }^{305}$; 4) o preço para exercício das opções financeiras é determinado e único, ao contrário do preço das opções reais; 5) as opções financeiras tendem a ser únicas, ao passo que as opções reais tendem a ser variadas; 6) as opções financeiras são de exclusividade do investidor, ao contrário das opções reais; 7) as opções financeiras têm preços ajustados continuamente pelo mercado, mas as opções reais não ${ }^{306}$.

Em relação às opções reais relacionadas a projetos de venture capital, podemos entender que: 1) a vida útil da opção tende a ser de longo prazo, porque o desenvolvimento do projeto costuma perdurar por vários anos; 2) para o investidor, o momento ideal para exercício da opção é fundamental para decidir entre as alternativas de renegociar o contrato com o empreendedor ou tentar interromper perdas; 3) para o empreendedor, o custo do não exercício da opção é alto, pois pode significar a interrupção do projeto; 4) há pouca possibilidade de comercializar o objeto do investimento; 5) a opção é de uso exclusivo do investidor e do empreendedor, não podendo ser exercida por terceiros.

\footnotetext{
${ }^{305}$ Essa é uma das principais razões a favor do uso da teoria das opções reais em investimentos em commodities, pois as informações sobre o preço desses ativos são facilmente observáveis. (PASIN, Rodrigo M.; MARTELANC, Roy; Souza, Almir F. A flexibilidade do processo decisório e o valor da opção de adiamento. VI SEMEAD - Seminários em Administração FEA-USP. (Março, 2003). Disponível em: <http://www.ead.fea.usp.br/Semead/6semead/ >. Acesso em: 22.06.2009).

${ }^{306}$ MINARDI, Andrea M. A. F. Teoria das opções aplicada a projetos de investimento. Revista de Administração de Empresas (RAE), V. 40, n. 2, pp. 74-79, Abr./Jun. 2000.
} 


\section{VI.4. Incentivos à Inovação: Fontes de Informação Utilizadas}

Indicamos as principais fontes de informação e estudos utilizados para análise dos incentivos à inovação, que servem como indicação de tendência. O tema não é foco desta tese, razão pela qual não o detalhamos.

O inciso XXIX do artigo $5^{\circ}$, da Constituição Federal, prevê a norma programática para proteção de criações industriais com vistas ao interesse social, desenvolvimento tecnológico e econômico, complementada pelas normas que sustentam a promoção, pelo Estado, do desenvolvimento científico (artigo 218) e incentivo ao desenvolvimento privado da autonomia tecnológica do país (artigo 219).

A legislação infraconstitucional inclui a proteção à propriedade imaterial, assim como incentivos tributários sob a forma de isenções fiscais e outros benefícios como, por exemplo, a depreciação contábil acelerada do investimento. Destacamos a Lei n. 8.248/91 (lei de incentivos à inovação), Lei n. 10.168/00 (institui a contribuição de intervenção de domínio econômico - CIDE - destinada a financiar o Programa de Estímulo à Interação Universidade-Empresa para o Apoio à Inovação), Lei n. 8.661/93, revogada pela Lei n. 11.196/05 (conhecida como “MP do Bem”), Lei n. 10.973/04 (Lei da Inovação, que dispõe sobre incentivos à inovação e pesquisa científica e tecnológica no ambiente produtivo), incentivos previstos na Lei de Informática (Leis n. 10.664/03 e n. 11.077/04), Código de Propriedade Industrial (Lei n. 9.279/96), leis esparsas de proteção a direitos imateriais específicos e outras.

Os benefícios previstos pela "MP do Bem” (Lei n. 11.196/05, regulamentada pelo Decreto n. 5.798/06) são de difícil aplicação a negócios de venture capital que apresentem prejuízo contábil, por não haver base de cálculo para pagamento do imposto de renda e contribuição social sobre o lucro, o que impede a utilização dos incentivos tributários em anos seguintes, situação da maioria desses empreendimentos, que são deficitários em seus primeiros anos de desenvolvimento.

O procedimento administrativo para concessão de patentes a cargo do Instituto Nacional da Propriedade Industrial - INPI dura vários anos, tornando a proteção 
jurídica ineficaz em diversas situações. A título de exemplo, o Programa Piloto de Patentes Verdes, realizado em 2012, foi um esforço deste órgão visando a reduzir o tempo total para concessão de patentes no âmbito de inovações de cunho ambiental. $\mathrm{O}$ tempo médio de concessão das "patentes verdes" foi reduzido para menos de dois $\operatorname{anos}^{307}$, mas tem levado de seis a dez anos para os demais casos. Os prazos podem ser considerados elevados para atender as demandas de negócios de venture capital.

A inexistência de incentivos tributários específicos e a legislação trabalhista excessivamente protecionista têm sido mencionadas em diversos estudos como incentivos negativos ao desenvolvimento de negócios de venture capital ${ }^{308}$.

A título de exemplo, a Coréia do Sul têm direcionado esforços ao desenvolvimento da inovação e obtido resultados positivos. Nesse sentido, o Brasil vem ocupando posição decrescente no índice global de competitividade tecnológica (The Networked Readiness Index); de um total de 175 nações avaliadas, o Brasil ocupava, em 2003, a $29^{a}$ posição, caindo para a $65^{\text {a }}$ posição em 2012. A Coréia do Sul ocupava, em 2012, a $12^{\mathrm{a}}$ posição nesse índice ${ }^{309,310,311}$.

A literatura especializada em inovação debate se há, ou não, correlação entre a quantidade de patentes depositadas em um país e a existência de ambiente institucional

\footnotetext{
${ }^{307}$ Instituto Nacional de Propriedade Intelectual (INPI), Disponível em: <http://www.inpi.go v.br/portal/artigo/patentes_verdes>. Acesso em: 07.06.2013; Instituto Nacional de Propriedade Intelectual (INPI), Disponível em:

<http://www.inpi.go v.br/portal/artigo/inpi_concede_primeira_patente_verde_do_brasil >.Acesso em: 07.06.2013.

${ }^{308}$ Fundação Getúlio Vargas (GVCEPE). A indústria de private equity e venture capital - segundo censo brasileiro. $1^{\text {a }}$ Ed., Março/2011. Disponível em: <http://gvcepe.com/>. Acesso em: 03.04.2012, pp. 109; 124 125; 174-175; 308; 368; 374); PRICEWATERHOUSECOOPERS. Doing business and investing in Brazil. São Paulo, 2013. Disponível em: <http://www.pwc.com.br/>. Acesso em: 09.06.2013,p. 84.

${ }^{309}$ De acordo com BECK, em 2012, o Brasil investiu apenas $1,08 \%$ do PIB em pesquisa e desenvolvimento, com pequena contribuição da indústria em relação ao total investido, enquanto a Coréia do Sul investiu $3,36 \%$ do PIB. O autor menciona que a carga tributária no Brasil é de $38 \%$ do PIB, enquanto a da Coréia do Sul é de $26 \%$, cerca de metade da brasileira. (BECK, Mario. Na Coreia do Sul, inovação é quase uma religião. O Globo, 09.06.2012, Disponível em: <http://oglobo.globo.com/economia/na-coreia-do-sulinovacao-quase-uma-religiao-5159424>. Acesso em: 09.02.2013)

${ }^{310}$ Do total de 175 nações avaliadas pelo ranking tecnológico mundial, o Brasil ocupava a $52^{\mathrm{a}}$ posição em 2005, caindo para a $53^{\mathrm{a}}$ posição em 2006, e 59 ${ }^{\mathrm{a}}$ posição em 2009. (CHADE, Jamil. Brasil cai em ranking tecnológico global. $\mathrm{O}$ Estado de São Paulo. 10.04.2008. Disponível em: <http://www.estadao.com.br/noticias/impresso,brasil-cai-em-ranking-tecnologico-global,154184,0.html>. Acesso em: 09.02.2013).

311 World Economic Forum. The Global Information Technology Report 2012. Disponível em: <http://www.weforum.org/issues/global-information-technology/index.html>. Acesso em: 09.02.2013.
} 
favorável ao desenvolvimento da inovação ${ }^{312,313}$. Se entendermos haver correlação positiva, a situação do Brasil é inferior à de países como a Coréia do Sul. Apesar de haver crescimento na quantidade total de patentes solicitadas no país, de acordo com a Organização Mundial de Propriedade Intelectual (OMPI), no período entre 2005 e 2009, foram depositadas cerca de 110 mil patentes no INPI, ante as 833 mil depositadas na Coréia do Sul no mesmo período ${ }^{314,315}$.

Os incentivos à inovação são objeto de estudo dos diversos estudos, entre os quais destacamos:

- Latin America Venture Capital Association (LAVCA): apresenta análise crítica detalhada e um scorecard sobre os principais incentivos na perspectiva do investidor estrangeiro ${ }^{316}$;

- Segundo Censo Brasileiro da Indústria de Private Equity e Venture Capital, realizado pela Fundação Getúlio Vargas (GVCEPE): tem por

\footnotetext{
${ }^{312}$ Perspectiva histórica e debate sobre políticas públicas de inovação e legislação de patentes apresentados por: HAHN, Robert W. The economics of patent protection: policy implications from the literature. October 30, 2003. Disponível em: <www.ssrn.com/paper.taf?abstract_id=467489>. Acesso em: 18.02.2013.

${ }^{313}$ Debate sobre a correlação entre depósito de patentes e a qualidade da inovação e das fontes de financiamento apresentada em: CAO, Jerry X.; HSU, Po-Hsuan. Patent signaling, entrepreneurial performance, and venture capital financing. September, 2010. Disponível em: <http://papers.ssrn.com/paper.taf?abstract_id=1678809>. Acesso em: 20.09.2010.

${ }^{314}$ World Intellectual Property Organization (WIPO). WIPO IP facts and figures - 2011. Disponível em: <www.wipo.int/freepublications/en/statistics/943/wipo_pub_943_2011.pdf>. Acesso em: 18.02.2013, p. 12; Ver também indicadores gerais dos escritórios de patentes em: World Intellectual Property Organization (WIPO). Indicators - $2012 \quad$ Edition. Disponível em: <www.wipo.int/export/sites/www/freepublications/en/intproperty/941/wipo_pub_941_2012.pdf>. Acesso em: 18.02.2013.

${ }^{315}$ Segundo a pesquisa do IBGE para o período 2006-2008, 34\% dos negócios utilizam mecanismos formais (exemplo: patentes) ou estratégicos (exemplo: segredos industriais) para proteção de inovações, porém a taxa de proteção ao setor de serviços supera a do industrial. Do total de casos analis ado, $61,5 \%$ dos negócios que solicitaram proteção de patentes estão voltados para pesquisa e desenvolvimento, 9,1\% são indústrias e 5,2\% são prestadoras de serviços. Destaca-se a proteção de marcas (24,3\% na indústria e $34,1 \%$ em serviços), padrão já observado em pesquisas anteriores. Entre os obstáculos indicados pelo setor industrial, destacam-se os elevados custos da inovação $(73,2 \%)$, riscos econômicos excessivos $(65,9 \%)$, carência de pessoal qualificado $(57,8 \%)$ e escassez de fontes de financiamento $(51,6 \%)$. A pesquisa mostra que, das 106.862 sociedades analisadas, apenas 41.262 implantaram inovações e somente 2.968 requereram patentes. (Instituto Brasileiro de Geografia e Estatística (IBGE). Pesquisa de inovação tecnológica: 2008. Rio de Janeiro: IBGE, 2010. Disponível em: <http://www.pintec.ibge.gov.br>. Acesso em: 17.02.2013, pp. 54-55; 74).

316 LAVCA (Latin America Venture Capital Association). The private equity and venture capital environment in Latin America - Scorecard, 2012. Disponível em: 〈www.lavca.org〉. Acesso em 19.02.2013.
} 
objetivo a análise detalhada do mercado brasileiro ${ }^{317}$;

- Estudo do Mercado Brasileiro de Private Equity e Venture Capital, realizado pela escola de negócios INSEAD em parceria com a empresa de auditoria e consultoria PricewaterhouseCoopers: apresenta análise detalhada a respeito do ambiente institucional brasileiro ${ }^{318}$.

\footnotetext{
${ }^{317}$ Fundação Getúlio Vargas (GVCEPE). A indústria de private equity e venture capital - segundo censo brasileiro. $1^{\text {a }}$ Ed., Março/2011. Disponível em: <http://gvcepe.com/>. Acesso em: 03.04.2012, pp. 389-407. ${ }^{318}$ Insead Business School; PricewaterhouseCoopers. INSEAD - PwC study on private equity - Brazilian private equity: moving centre strategy. 2013. Disponível em: <http://www.pwc.com.br/>. Acesso em: 09.06.2013, pp. 14-16.
} 